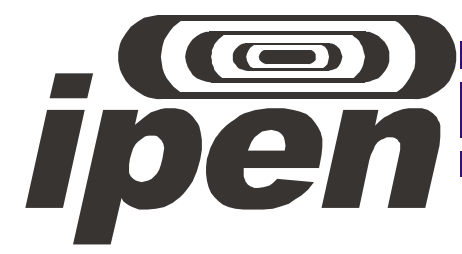

AUTARQUIA ASSOCIADA À UNIVERSIDADE DE SÃO PAULO

RECUPERAÇÃO/RECICLAGEM DE COMPOSTOS DE BORRACHAS BUTÍLICA E HALOBUTÍLICA POR MEIO DE RADIAÇÃO IONIZANTE

Sandra Regina Scagliusi Martin

Tese apresentada como parte

dos requisitos para obtenção do Grau

de Doutor em Ciências na Área

de Tecnologia Nuclear - Materiais

Orientador:

Prof. Dr. Ademar Benévolo Lugão 


\section{ipen}

INSTITUTO DE PESQUISAS ENERGÉTICAS E NUCLEARES

Autarquia associada à Universidade de São Paulo

\section{RECUPERAÇÃO/RECICLAGEM DE COMPOSTOS DE BORRACHAS BUTÍLICA E HALOBUTÍLICA POR MEIO DE RADIAÇÃO IONIZANTE}

SANDRA REGINA SCAGLIUSI MARTIN

Tese apresentada como parte dos requisitos para obtenção do Grau de Doutor em Ciências na Área de Tecnologia Nuclear - Materiais.

Orientador:

Ademar Benévolo Lugão

Versão Corrigida

Versão Original se encontra no IPEN

São Paulo 
Seja menos curioso sobre as pessoas e mais sobre as ideias.

Marie Curie. 
À Minha família pela ajuda, carinho, paciência e força incondicionais durante todos os momentos da minha vida e da realização deste trabalho. 


\section{AGRADECIMENTOS}

À Deus, que por sua presença, luz e força sempre me abençoa e capacita para tudo aquilo que ele me destina.

Ao Dr Ademar Benévolo Lugão, meu orientador, pelo incentivo, pelos conselhos, pela dedicação, pela amizade, pela compreensão e apoio em todos os momentos, meus profundos agradecimentos.

Gostaria ainda de agradecer: ao Prof. Dr. Traian Zaharescu pelos comentários, sugestões e incentivo.

Meus respeitosos agradecimentos pela contribuição da banca do exame de qualificação e pela participação dos membros da banca examinadora da defesa do doutorado.

Ao Instituto de Pesquisas Energéticas e Nucleares - IPEN pela oportunidade da realização deste trabalho.

À Flexlab Consultoria., especialmente ao diretor Marcelo Eduardo da Silva, pela colaboração e apoio técnico que foram prestados durante o tempo de preparação deste trabalho, a você muito obrigada.

À Basile Química., especialmente ao diretor Renato Basile e toda a sua equipe, pela colaboração e apoio técnico durante o tempo de preparação deste trabalho, a você muito obrigada.

Ao Dr. Helio Fernando Rodrigues Ferreto pela ajuda e colaboração.

Aos alunos de iniciação científica que muito colaboraram para realização deste trabalho Camila Pinheiro de Souza (In Memorium), Lilian Sayuri Ono e Cristina A. Pozenato. 
Aos meus amigos e colegas do CQMA que não menciono o nome, mas sabe quem são, e que estiveram a o meu lado durante esta fase, pelo companheirismo, força e apoio em certos momentos difíceis.

As minhas estimáveis amigas de sala Heloisa A. Zen e Elisabeth C.L. Cardoso, pelo carinho e incentivos constantes, acreditando ser possível cumprir esta árdua missão.

Ao meu marido Roberto, pelo apoio e carinho e por vivenciar todas as dificuldades ao longo desse período.

À minha família, em particular, minha mãe, Mathilde pelo incentivo e colaboração. Sem o seu apoio à caminhada seria mais intensa.

À Comissão de Energia Nuclear - CNEN, pelo apoio financeiro.

Por último a todos aqueles que de alguma forma contribuíram direta ou indiretamente, para confecção deste trabalho, o meu sincero reconhecimento e muito obrigado. 


\title{
RECUPERAÇÃO/RECICLAGEM DE COMPOSTOS DE BORRACHAS BUTÍLICA E HALOBUTÍLICA POR MEIO DE RADIAÇÃO IONIZANTES
}

\author{
Sandra Regina Scagliusi Martin
}

\section{RESUMO}

Materiais poliméricos (plásticos e borrachas) abrangem uma proporção continuamente crescente de resíduos urbanos e industriais descartados em aterros, seus impactos no meio ambiente são cada vez mais preocupantes. A implementação de novas tecnologias em prol da redução dos resíduos poliméricos, aceitáveis do ponto de vista ambiental e a um custo eficaz, provou ser um grande problema, face às complexidades inerentes para a reutilização dos polímeros. A radiação ionizante tem capacidade para alterar a estrutura e propriedades dos materiais poliméricos. As borrachas butílicas e halobutílicas têm sido usadas em larga escala, numa variedade de aplicações tais como partes de pneus e artefatos diversos. O principal efeito do fóton de alta energia, como raios gama nas borrachas butílicas e butílicas halogenadas é a geração de radicais livres, acompanhada por mudanças nas propriedades mecânicas. O objetivo deste trabalho é desenvolver processos de degradação controlada (desvulcanização) de borrachas butílicas e halobutílicas (cloro e bromo), de modo a caracterizar sua disponibilidade para transformação e alteração de suas propriedades. Os resultados experimentais obtidos mostraramm que as borrachas butílica e halobutílicas irradiadas a 25 kGy e posteriormente cisalhadas podem ser usadas como ponto de partida para misturas com borracha virgem. 


\title{
RECOVERING/RECYCLING OF BUTYL AND HALOGENATED BUTYL RUBBER VIA IONIZING
}

\author{
RADIATION
}

Sandra Regina Scagliusi Martin

\begin{abstract}
Polymeric materials (plastics and rubbers) attain a continuous and raising proportion of urban and industrial scraps discarded in landfills; their impact on environment are more and more concerning. The implementation of new technologies in order to reduce impacts of plastic waste on the environment, at an effective cost, proved to be a great problem, due to inherent complexity for polymers re-using. Ionizing radiation is capable to modify structure and properties of polymeric material. Butyl and halobutyl rubbers have been used within a comprehensive scale, applications such as tires spare parts and diverse artifacts. The major high energy photon effect, as gamma-rays in butyl and halo butyl rubbers consists in free-radicals generation along changes in mechanical properties. This work aims to the development of controlled degradation processes (devulcanization) of butyl and halo butyl (chlorine and bromine) rubbers, in order to characterize their availability for transformation and modification of properties. Experimental results obtained showed that butyl and halobutyl rubbers,irradiated at $25 \mathrm{kGy}$ and further sheared, are able to be used as an initial point for mixtures with pristine.
\end{abstract}




\section{Sumário}

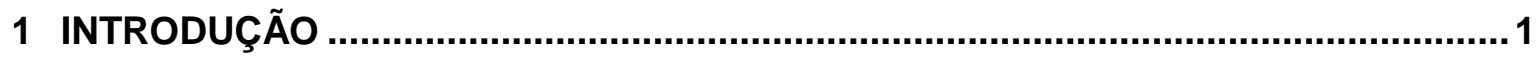

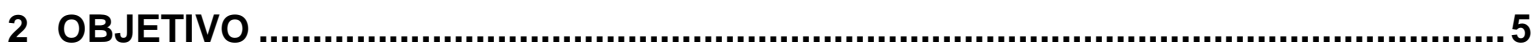

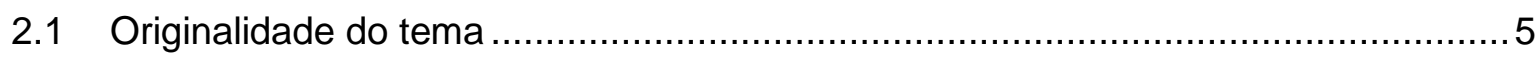

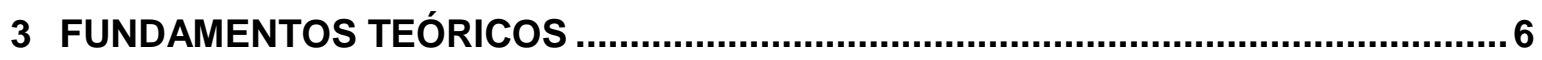

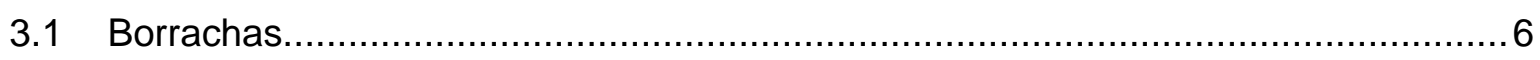

3.1.1 História da borracha.................................................................................. 7

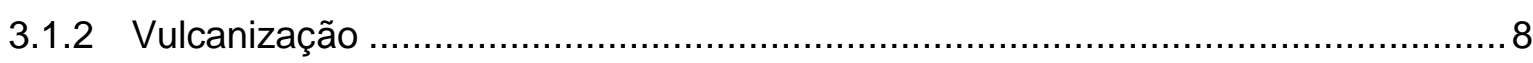

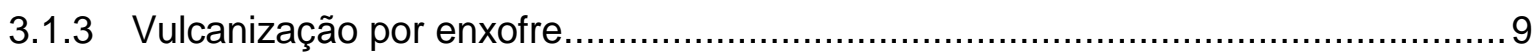

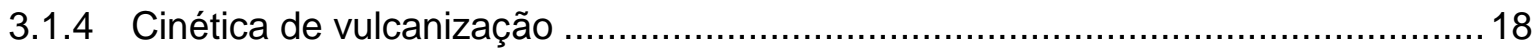

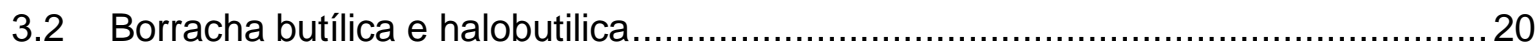

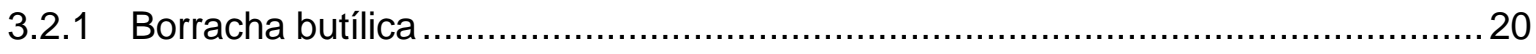

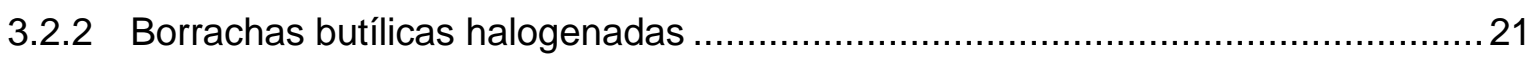

3.2.3 Vulcanização da borracha butílica e butílica halogenada ................................... 23

3.2.4 Mecanismo de vulcanização com enxofre e aceleradores. .................................. 27

3.3 Reaproveitamento/Reciclagem de borrachas ................................................... 29

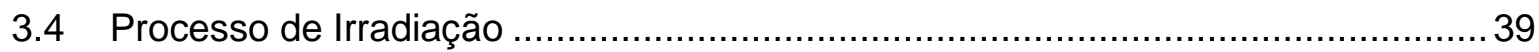

3.4.1 Efeitos da radiação de alta energia em polímeros........................................... 39

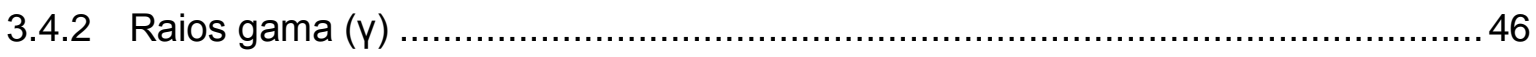

3.4.3 Interação das radiações ionizantes com borrachas butílicas e halobutílicas ........ 47

3.4.4 Aplicação da radiação ionizante para reciclagem das borrachas butílicas e

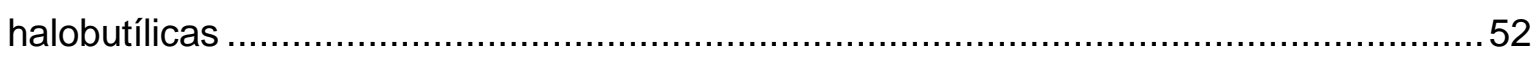

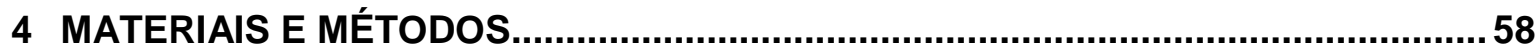

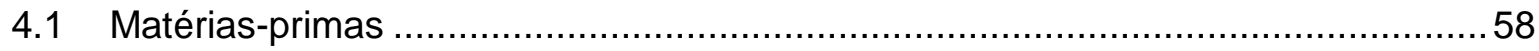

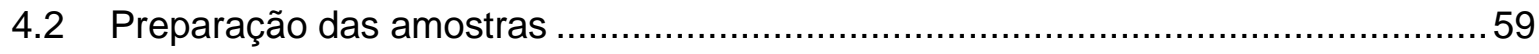

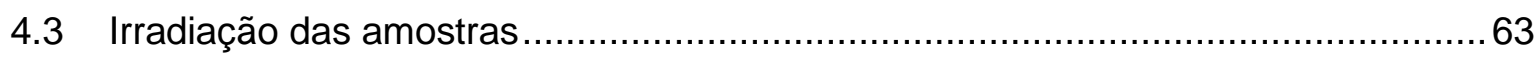

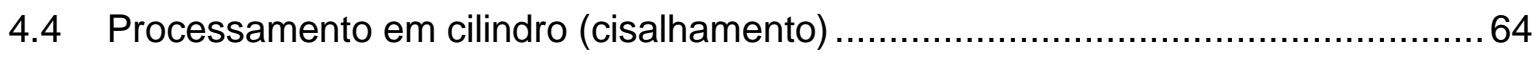

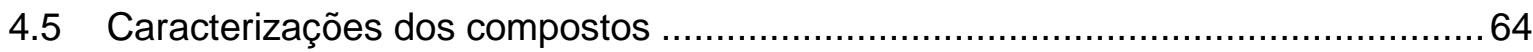

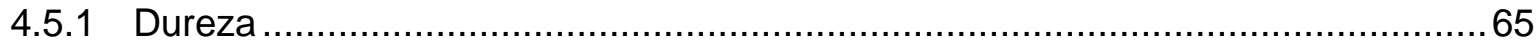

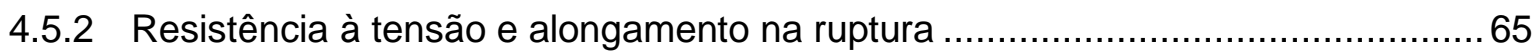

4.5.3 Determinação do índice de inchamento de borracha ....................................... 65 


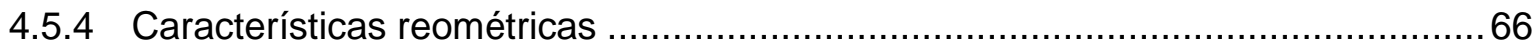

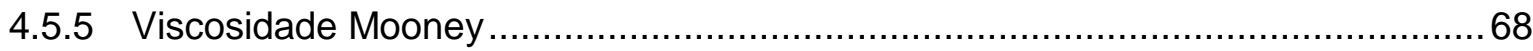

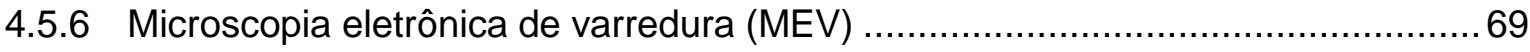

4.5.7 Análise mecânico-dinâmica (DMA) …..................................................... 70

4.6 Obtenção de compostos contendo borracha recuperada/reciclada .......................70

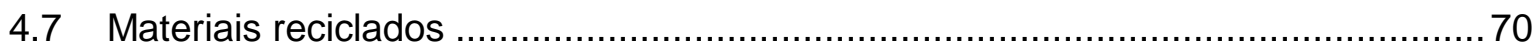

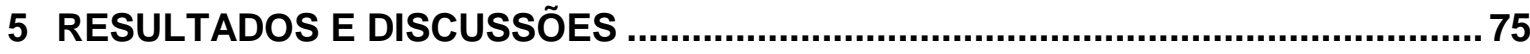

5.1 Efeito da radiação na viscosidade das borrachas butílicas .................................. 75

5.2 Efeito da radiação nos parâmetros reométricos de vulcanização ............................78

5.2.1 Torque máximo $(\mathrm{MH})$ dos compostos de borrachas butílica e halobutílica irradiadas .79

5.2.2 Torque máximo $(\mathrm{MH})$ dos compostos de borrachas butílica e halobutílica irradiadas e cisalhadas.

5.2.3 Torque mínimo (ML) dos compostos de borrachas butílica e halobutílica irradiadas.

5.2.4 Torque mínimo (ML) dos compostos de borrachas butílica e halobutílica irradiadas e cisalhadas

5.2.5 Diferença entre o torque máximo $(\mathrm{MH})$ e torque mínimo $(\mathrm{ML})$ dos compostos de borrachas butílica e halobutílica não irradiadas, irradiadas e das borrachas irradiadas e cisalhadas. .90

5.3 Propriedade Dinâmico Mecânico - (DMA) …..................................................... 92

5.4 Tensão e Alongamento na Ruptura. 97

5.4.1 Tensão e alongamento na ruptura dos compostos de borrachas butílica irradiadas.

5.4.2 Tensão e alongamento na ruptura dos compostode borrachas halobutílica irradiadas .99

5.4.3 Tensão e alongamento na ruptura dos compostos de borracha butílica irradiados e cisalhados 101

5.4.4 Tensão e alongamento na ruptura dos compostos de borrachas halobutílica irradiadas e cisalhadas. 103

5.4.5 Efeito da irradiação na dureza dos compostos de borrachas butílica e halobutílica irradiadas 108

5.4.6 Efeito da irradiação na dureza dos composto de borrachas butílicas e halobutílicas irradiadas seguidas de cisalhamento 
5.5 Inchamento (Swelling)...

5.5.1 Inchamento (Swelling) dos compostos de borracha butílica irradiadas 112

5.5.2 Inchamento (Swelling) dos compostos de borracha bromobutílica irradiadas .... 116

5.5.3 Inchamento (Swelling) dos compostos de borracha clorobutílica irradiados....... 119

5.5.4 Inchamento (Swelling) dos compostos de borracha butílica irradiados e cisalhados.

5.5.5 Inchamento (Swelling) dos compostos de borracha bromobutílica irradiados e cisalhados 125

5.5.6 Inchamento (Swelling) dos compostos de borracha clorobutílica irradiados e cisalhados 128

5.6 Microscopia Eletrônica de Varredura (MEV) com EDS. 131

5.6.1 Microscopia Eletrônica de Varredura (MEV) com EDS dos compostos de borrachas butílica e halobutílica irradiados.

5.6.2 Microscopia Eletrônica de Varredura (MEV) com EDS dos compostos de borracha butílica e halobutílica irradiadas e cisalhadas.

6 RECICLAGEM 148

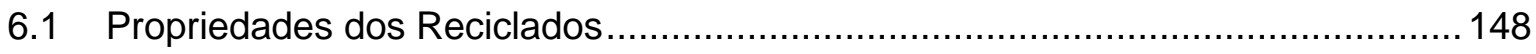

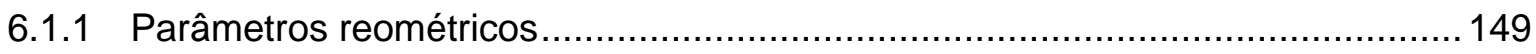

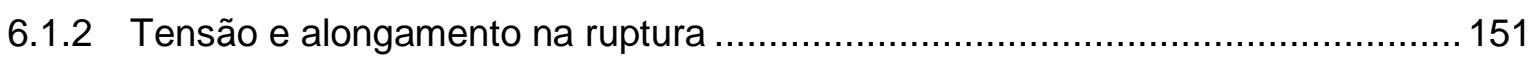

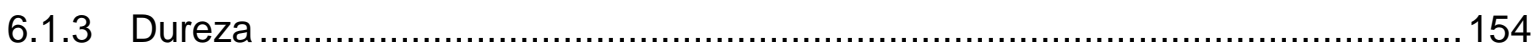

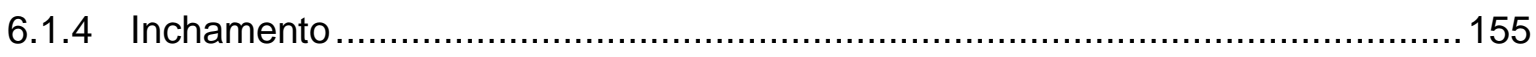

6.1.5 Microscopia Eletrônica de Varredura (MEV) ................................................ 158

6.1.6 Viscosidade Mooney dos compostos recuperados/reciclados.......................... 161

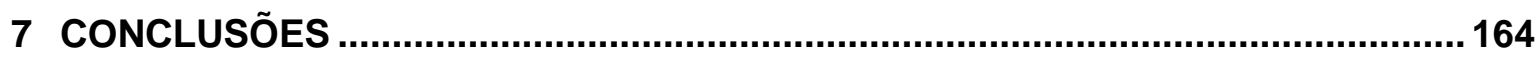

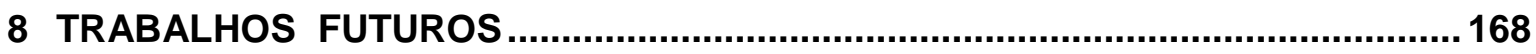

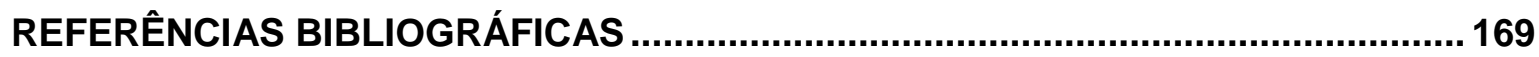




\section{ÍNDICE DE FIGURAS}

FIGURA 1: Esquema da estrutura da borracha não vulcanizada ${ }^{22} \ldots \ldots \ldots \ldots \ldots \ldots \ldots 6$

FIGURA 2: Modelo molecular do processo de vulcanização. .............................9

FIGURA 3: Reações de vulcanização de elastômero utilizando enxofre sem a

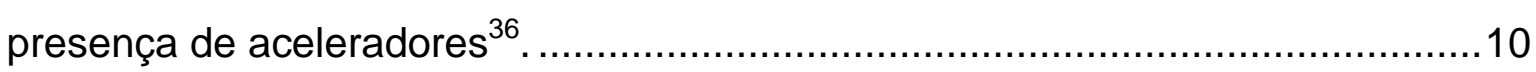

FIGURA 4: Principais aceleradores utilizados na vulcanização de elastômeros com enxofre ${ }^{40}$

FIGURA 5: Tipos de ligações estabelecidas na vulcanização com enxofre (a) ligação na cadeia principal de duas macromoléculas de borracha (b) ligação em que o enxofre e o acelerador estão ligados à cadeia principal; (c) ligações mono e dissulfídica cíclicas (extra reticulares)......

FIGURA 6: Rota geral para o processo de vulcanização com acelerador e enxofre ${ }^{48}$

FIGURA 7: Variação de propriedades de um elastômero vulcanizado em função da formação de ligações cruzadas ${ }^{50}$.

FIGURA 8: Curva típica de uma análise por reômetro de disco oscilatório ${ }^{61} \ldots . . . .19$

FIGURA 9: Ilustração da estrutura da borracha butílica..................................21

FIGURA 10: Estrutura da borracha butílica halogenada ..................................22

FIGURA 11: Estrutura genérica da resina de cura (resina de octil formol-

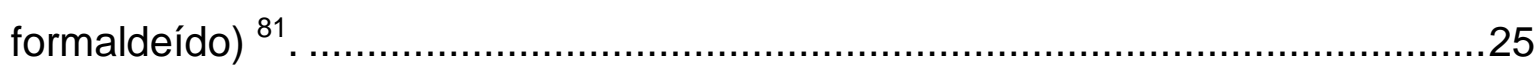

FIGURA 12: Reação da resina de cura com as duplas ligações do C-C da cadeia polimérica $^{81}$.

FIGURA 13: Resumo do esquema da reação da borracha butílica curada com resina.

FIGURA 14: Possível mecanismo de vulcanização das borrachas butílicas com agente de cura do tipo tiuram (TMTD) ${ }^{40}$

FIGURA 15: Esquema de reação de vulcanização das borrachas butílicas usando

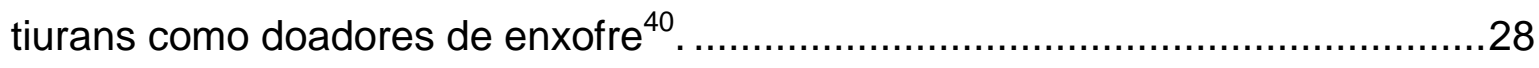

FIGURA 16: Esquema de ionização e excitação. .........................................40

FIGURA 17: Produtos de interação da radiação com átomos ou moléculas. .......41

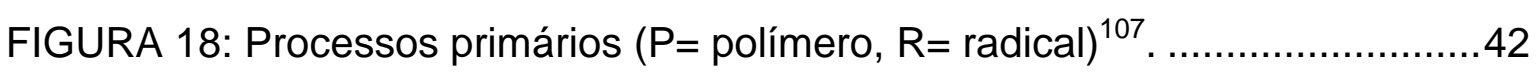

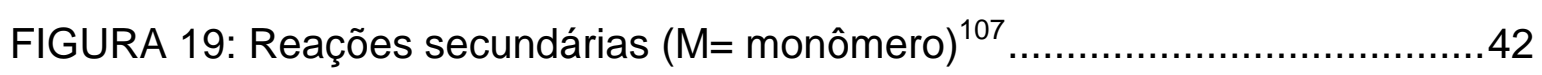

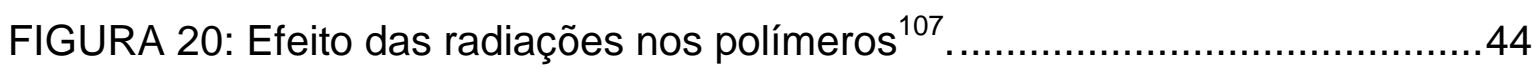


FIGURA 21: Transformação do Cobalto-59 em Cobalto-60.

FIGURA 22: Reações intramoleculares envolvidas no processo de reticulação das borrachas halobutílicas ${ }^{117}$. 49

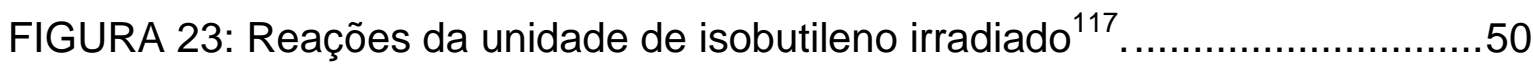

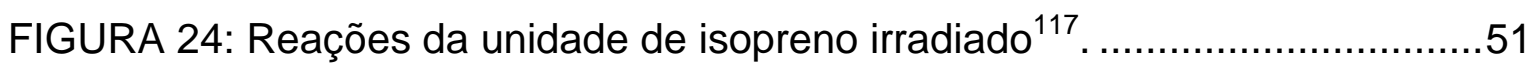

FIGURA 25: Misturador de cilindro aberto de dois rolos (Copê)........................61

FIGURA 26: Modelo de corpo de prova em manta (a) e picotados (b). ...............62 62

FIGURA 27: Fluxograma dos processos e das caracterizações das amostras antes da irradiação

FIGURA 28: Fluxograma dos processos e das caracterizações das amostras depois da irradiação. 63

FIGURA 29: Amostra após a irradiação e cisalhamento .64

FIGURA 30: Foto do corpo-de-prova do ensaio de tensão e alongamento na ruptura, marcado com dois traços. .65

FIGURA 31: Esquema da cavidade de teste dos reômetros tipo MDR ${ }^{58}$. .67

FIGURA 32: Esquema da cavidade de teste de viscosímetro Mooney ${ }^{60}$. 68

FIGURA 33: Fluxograma do processo de mistura das amostras de borrachas butílica e halobutílica contendo 70 phr de borracha virgem e 30 phr de borracha irradiada (25 kGy) e cisalhadas e das amostras das borrachas contendo 100 phr de borracha virgem. .73

FIGURA 34: Viscosidade Mooney da borracha butílica, bromobutílica e clorobutílica irradiada e não irradiada. Butílica (azul), bromobutílica (vermelho) e clorobutílica (verde). .75

FIGURA 35: Reação intramolecular envolvendo formação de reticulação ${ }^{117}$. ......76 FIGURA 36: Aspecto visual das borrachas butílicas, bromobutílicas e clorobutílicas antes e depois de irradiar nas doses de 0, 5, 15, 25, 50, 100, 150 e 200 kGy. .77

FIGURA 37: Torque máximo dos compostos de (a) borracha butílica, (b) borracha bromobutílica e (c) borracha clorobutílica irradiada e não irradiada. Curada com resina (azul), enxofre (vermelho) e doador de enxofre (verde).

FIGURA 38: Efeito da dose de irradiação seguido de cisalhamento para torque máximo dos compostos de (a) borracha butílica, (b) borracha bromobutílica e (c) borracha clorobutílica. Curada com resina (azul), enxofre (vermelho) e doador de enxofre (verde). 
FIGURA 39: Torque mínimo dos compostos de (a) borracha butílica, (b) borracha bromobutílica e (c) borracha clorobutílica irradiada e não irradiada. Curada com resina (azul), enxofre (vermelho) e doador de enxofre (verde). .85 FIGURA 40: Estrutura cíclica de reticulação por resina na borracha butílica ${ }^{81}$.....86 FIGURA 41: Torque mínimo dos compostos de (a) borracha butílica, (b) borracha bromobutílica e (c) borracha clorobutílica irradiadas e cisalhadas. Curada com resina (azul), enxofre (vermelho) e doador de enxofre (verde). .88 FIGURA 42: Tan $\delta$ da amostra 2 (butílica curada com enxofre) em função da temperatura para as amostras irradiadas e não irradiadas.

FIGURA 43: Influência da dose de irradiação no módulo de armazenamento (E') da amostra 2 (butílica curada com enxofre) em função da dose na temperatura de $-80^{\circ} \mathrm{C}$ para amostra não irradiada e irradiada. .93 FIGURA 44: Tan $\delta$ da amostra 2 (butílica curada com enxofre) em função da dose na temperatura de $-80^{\circ} \mathrm{C}$ para amostra irradiada e não irradiada. 93 FIGURA 45: Influência da dose de irradiação no módulo de armazenamento (E') da amostra 2 (butílica curada com enxofre) em função da dose na temperatura de $+80^{\circ} \mathrm{C}$ para amostra não irradiada e irradiada.

FIGURA 46: Tan $\delta$ da amostra 2 (butílica curada com enxofre) em função da dose na temperatura de $+80^{\circ} \mathrm{C}$ para amostra irradiada e não irradiada .95

FIGURA 47: Influência da dose de irradiação no módulo de armazenamento (E') da amostra 2 (butílica curada com enxofre) em função da dose na temperatura de transição vítrea $(\mathrm{Tg})$ para amostra não irradiada e irradiada. .96 FIGURA 48: Tan $\delta$ da amostra 2 (butílica curada com enxofre) em função da dose na temperatura de Tg para amostra irradiada e não irradiada. .96 FIGURA 49: Efeito da dose de radiação na tensão de ruptura dos compostos de borracha butílica curada com resina (azul), enxofre (vermelho) e doador de enxofre (verde), irradiados e não irradiados 97

FIGURA 50: Efeito da dose de radiação no alongamento na ruptura dos compostos de borracha butílica curada com resina (azul), enxofre (vermelho) e doador de enxofre (verde), irradiados e não irradiados .98 FIGURA 51: Efeito da dose de radiação na tensão de ruptura dos compostos de borracha bromobutílica curada com resina (azul), enxofre (vermelho) e doador de enxofre (verde), irradiados e não irradiados. .99 
FIGURA 52: Efeito da dose de radiação no alongamento na ruptura dos compostos de borracha bromobutílica curada com resina (azul), enxofre (vermelho) e doador de enxofre (verde), irradiados e não irradiados. 99 FIGURA 53: Efeito da dose de radiação na tensão de ruptura dos compostos de borracha clorobutílica curada com resina (azul), enxofre (vermelho) e doador de enxofre (verde), irradiados e não irradiados. 100

FIGURA 54: Efeito da dose de radiação no alongamento na ruptura dos compostos de borracha clorobutílica curada com resina (azul), enxofre (vermelho) e doador de enxofre (verde), irradiados e não irradiados. 100 FIGURA 55: Efeito da dose de radiação e do cisalhamento na tensão de ruptura dos compostos de borracha butílica curada com resina (azul), enxofre (vermelho) e doador de enxofre (verde). 102 FIGURA 56: Efeito da dose de radiação seguida de cisalhamento no alongamento na ruptura dos compostos de borracha butílica curada com resina (azul), enxofre (vermelho) e doador de enxofre (verde). 102 FIGURA 57: Efeito da dose de radiação e cisalhamento na tensão de ruptura dos compostos de borracha bromobutílica curada com resina (azul), enxofre (vermelho) e doador de enxofre (verde). 104

FIGURA 58: Efeito da dose de radiação seguida de cisalhamento no alongamento na ruptura dos compostos de borracha bromobutílica curada com resina (azul), enxofre (vermelho) e doador de enxofre (verde). .104

FIGURA 59: Efeito da dose de radiação e cisalhamento na tensão de ruptura dos compostos de borracha clorobutílica curada com resina (azul), enxofre (vermelho) e doador de enxofre (verde). 105 FIGURA 60: Efeito da dose de radiação seguida de cisalhamento no alongamento na ruptura dos compostos de borracha clorobutílica curada com resina (azul), enxofre (vermelho) e doador de enxofre (verde). .105 FIGURA 61: Efeito da dose de irradiação e do cisalhamento na deformação da (a) borracha butílica curada com enxofre, (b) borracha bromobutílica curada com resina e (c) borracha clorobutílica curada com doador de enxofre, não irradiadas, irradiadas e irradiadas e cisalhadas.

FIGURA 62: Efeito da dose de radiação na dureza dos compostos de borracha (a) butílica, (b) bromobutílica e (c) clorobutílica curados com resina (azul), enxofre (vermelho) e doador de enxofre (verde), irradiados e não irradiados. .109 
FIGURA 63: Efeito da dose de radiação e cisalhamento na dureza dos compostos de borracha (a) butílica, (b) bromobutílica e (c) clorobutílica curada com resina (azul), enxofre (vermelho) e doador de enxofre (verde).

FIGURA 64: Resultado do inchamento dos compostos de borracha butílica curados com resina(a) (amostra 1), enxofre (b) (amostra 2) e doador de enxofre (c) (amostra 3) irradiados nas doses de 5, 15, 25, 50, 100, 150, e 200 kGy e não irradiados.

FIGURA 65: Imagem do composto de (borracha butílica curada com resina amostra 1), na dose de 200 kGy, após o teste de inchamento.

FIGURA 66: Resultado do inchamento dos compostos de borracha bromobutílica curados com resina) (a) (amostra 4), enxofre (b) (amostra 5) e doador de enxofre (c) (amostra 6) irradiadas nas doses de 5, 15, 25, 50, 100, 150, e 200 kGy e não irradiadas.

FIGURA 67: Imagem das formulações de borrachas bromobutílicas curadas com enxofre (amostra 5) e doador de enxofre (amostra 6) sem irradiação e irradiadas nas doses de 25 kGy e 200 kGy, após o teste de inchamento.

FIGURA 68: Resultado do inchamento dos compostos de borracha clorobutílica curados com resina (a) (amostra 7), enxofre (b) (amostra 8) e doador de enxofre (c)(amostra 9) irradiadas nas doses de 5, 15, 25, 50, 100, 150, e 200 kGy e não irradiadas. 120

FIGURA 69: Imagem das formulações de compostos de borracha clorobutílica curadas com resina (amostra 7) enxofre (amostra 8) e doador de enxofre (amostra 9) sem irradiação e irradiadas nas doses de 25 kGy e 200 kGy após o teste de inchamento. 121

FIGURA 70: Resultado do inchamento dos compostos de borracha butílica curados com resina (a) (amostra 1), enxofre (b) (amostra 2) e doador de enxofre (c) (amostra 3) irradiados nas doses de 5, 15, 25, 50, 100, 150 e 200 kGy e cisalhados. 123

FIGURA 71: Imagem dos compostos de borracha butílica curados com resina (amostra 1) enxofre (amostra 2) e doador de enxofre (amostra 3) irradiados na dose de 200 kGy e cisalhados, após o teste de inchamento. 125 FIGURA 72: Resultado do inchamento dos compostos de borracha bromobutílica curados com resina (a) (amostra 4), enxofre (b) (amostra 5) e doador de enxofre 
(c) (amostra 6) irradiados nas doses de 5, 15, 25, 50, 100, 150 e 200 kGy e cisalhados.

FIGURA 73: Imagem das borrachas bromobutílicas curadas com resina (amostra 4) enxofre (amostra 5) e doador de enxofre (amostra 6) irradiadas na dose de 200 kGy e cisalhadas após o teste de inchamento.

FIGURA 74: Resultado do inchamento dos compostos de borracha clorobutílica curados com resina (a) (amostra 7), enxofre (b) (amostra 8) e doador de enxofre (c) (amostra 9), irradiados nas doses de 5, 15, 25, 50, 100, 150 e 200 kGy e cisalhados.

FIGURA 75: Imagem dos compostos de borracha clorobutílica curados com resina (amostra 7), enxofre (amostra 8) e doador de enxofre (amostra 9) irradiados na dose de 200 kGy e cisalhados, após o teste de inchamento. 130

FIGURA 76: Micrografias e resultados de EDS da superfície de ruptura do composto de borracha butílica curado com resina (amostra 1) sem irradiar (a) e irradiada nas doses de 25 kGy (b) e 200 kGy (c).

FIGURA 77: Micrografias e resultados de EDS da superfície de ruptura do composto de borracha butílica curado com enxofre (amostra 2) sem irradiar (a) e irradiada nas doses de 25 kGy (b) e 200 kGy (c).

FIGURA 78: Micrografias e resultados de EDS da superfície de ruptura do composto de borracha butílica curado com doador de enxofre (amostra 3) sem irradiar (a) e irradiada nas doses de 25 kGy (b) e 200 kGy (c). 133 FIGURA 79: Micrografias e resultados de EDS da superfície de ruptura dos cimpostos de borracha bromobutílica curado com resina (amostra 4) sem irradiar (a) e irradiada nas doses de 25 kGy (b) e 200 kGy (c). 134 FIGURA 80: Micrografias e resultados de EDS da superfície de ruptura do composto de borracha bromobutílica curada com enxofre (amostra 5) sem irradiar (a) e irradiada nas doses de 25 kGy (b) e 200 kGy (c). 135 FIGURA 81: Micrografias e resultados de EDS da superfície de ruptura do composto de borracha bromobutílica curada com doador de enxofre (amostra 6) sem irradiar (a) e irradiada nas doses de 25 kGy (b) e 200 kGy (c). 136 FIGURA 82: Micrografias e resultados de EDS da superfície de ruptura do composto de borracha clorobutílica curado com resina (amostra 7) sem irradiar (a) e irradiado nas doses de 25 kGy (b) e 200 kGy (c). 
FIGURA 83: Micrografias e resultados de EDS da superfície de ruptura do composto de borracha clorobutílica curado com enxofre (amostra 8) sem irradiar (a) e irradiado nas doses de 25 kGy (b) e 200 kGy (c). 138 FIGURA 84: Micrografias e resultados de EDS da superfície de ruptura do composto de borracha clorobutílica curado com doador de enxofre (amostra 9) sem irradiar (a) e irradiado nas doses de 25 kGy (b) e 200 kGy (c)...............139 FIGURA 85: Micrografias e resultados de EDS da superfície de ruptura do composto de borracha butílica curada com resina (amostra 1) irradiada nas doses de (a) 25 kGy e (b) 200 kGy e cisalhadas.

FIGURA 86: Micrografias e resultados de EDS da superfície de ruptura do composto de borracha butílica curada com enxofre (amostra 2) irradiada nas doses de 25 kGy e 200 kGy e cisalhadas. 142

FIGURA 87: Micrografias e resultados de EDS da superfície de ruptura do composto de borracha butílica curada com doador de enxofre (amostra 3) irradiada nas doses de (a) 25 kGy e (b) 200 kGy e cisalhadas. 142 FIGURA 88: Micrografias e resultados de EDS da superfície de ruptura do composto de borracha bromobutílica curada com resina (amostra 4) irradiada nas doses de (a) 25 kGy e (b) 200 kGy e cisalhadas. 143 FIGURA 89: Micrografias e resultados de EDS da superfície de ruptura do composto de borracha bromobutílica curado com enxofre (amostra 5) irradiada nas doses de (a) 25 kGy e (b) 200 kGy e cisalhadas 144 FIGURA 90: Micrografias e resultados de EDS da superfície de ruptura do composto de borracha bromobutílica curado com doador de enxofre (amostra 6) irradiada nas doses de (a) 25 kGy e (b) 200 kGy e cisalhadas.

FIGURA 91: Micrografias e resultados de EDS da superfície de ruptura do composto de borracha clorobutílica curada com resina (amostra 7) irradiada nas doses de (a) 25 kGy e (b) 200 kGy e cisalhadas. 145 FIGURA 92: Micrografias e resultados de EDS da superfície de ruptura do composto de borracha clorobutílica curado com enxofre (amostra 8) irradiada nas doses de (a) 25 kGy e (b) 200 kGy e cisalhadas.

FIGURA 93: Micrografias e resultados de EDS da superfície de ruptura do composto de borracha clorobutílica curado com doador de enxofre (amostra 9) irradiada nas doses de (a) 25 kGy e (b) 200 kGy e cisalhadas. 
FIGURA 94: Resultado de tensão na ruptura dos compostos de borracha butílica e halobutílicas com 100 phr de borra virgem (azul) e com70 phr de borracha virgem $+30 \mathrm{phr}$ de borracha recuperada enxofre (vermelho). 152 FIGURA 95: Resultado de alongamento na ruptura dos compostos de borracha butílica e halobutílicas com 100 phr de borra virgem (azul) e com 70 phr de borracha virgem $+30 \mathrm{phr}$ de borracha recuperada enxofre (vermelho). 153 FIGURA 96: Resultado da dureza dos compostos de borracha butílica e halobutílicas com 100 phr de borracha virgem (azul) e com 70 phr de borracha virgem +30 phr de borracha recuperada enxofre (vermelho).

FIGURA 97: Resultado de inchamento dos compostos de borracha butílica e halobutílicas com 70 phr de borracha virgem + 30 phr de borracha recuperada.156 FIGURA 98: Imagem das borrachas butílicas, bromobutílica e clorobutílicas contendo $30 \mathrm{phr}$ de borracha recuperada por irradiação e cisalhamento, após o teste de inchamento. 158

FIGURA 99: Micrografias da superfície de ruptura dos compostos de borracha butílica contendo 30 phr de borracha irradiada e cisalhada curados com resina $(R C-1)$, enxofre (RC-2) e doador de enxofre (RC -3).

FIGURA 100: Micrografias da superfície de ruptura dos compostos de borracha bromobutílica contendo $30 \mathrm{phr}$ de borracha irradiada e cisalhada curados com resina ( $R C-4)$, enxofre ( $R C-5)$ e doador de enxofre (RC-6). 160

FIGURA 101: Micrografias da superfície de fratura dos compostos de borracha clorobutílica contendo phr de borracha irradiada e cisalhada curados com resina (RC-7), enxofre (RC-8) e doador de enxofre (RC-9).

FIGURA 102: Viscosidade Mooney $\mathrm{ML}(1+4), 100^{\circ} \mathrm{C}$ dos compostos de borracha butílica e halobutílicas formulados com 100 phr de borracha virgem e compostos de borracha butílica e halobutílicas formulados com 30phr de borracha recuperada por irradiação e cisalhamento. 162 


\section{ÍNDICE DE TABELAS}

TABELA 1: - Sistemas de vulcanização à base de enxofre e acelerador 17

TABELA 2: Valores de energia para ligações cruzadas em elastômeros. 18

TABELA 3: Energia e Comprimento das ligações entre carbono e halogênio 24 TABELA 4: Valores de $G$ para reticulação e cisão de cadeia de alguns polímeros $^{107}$. 45

TABELA 5: Formulação de borracha butílica .59

TABELA 6: Formulação de borracha bromobutílica 60

TABELA 7: Formulação de borracha clorobutílica 60

TABELA 8 : Nomenclatura das borrachas butílica e halobutílica confeccionadas com 30 phr de borracha irradiada e cisalhada. 71

TABELA 9: Formulações de borrachas butílica e halobutílica misturadas com as borrachas butílicas e halobutílicas irradiadas a 25 kGy e posterior mente cisalhadas.

TABELA 10: Tempo ( $\left.T_{90}\right)$ de vulcanização dos compostos de borrachas butílica, bromobutílica e clorobutílica. 79

TABELA 11: Resultado do $\Delta \mathrm{M}$ (dN.m) dos compostos de borrachas butílica, bromobutílica e clorobutílica irradiadas e não irradiadas. .90

TABELA 12: Resultado do $\triangle \mathrm{M}$ (dN.m) dos compostos de borrachas butílica, bromobutílica e clorobutílica irradiadas e cisalhadas.

TABELA 13: Variação da massa seca dos compostos de borracha butílica curado com resina, enxofre e doador de enxofre, irradiados e não irradiados.

TABELA 14: Variação da massa seca dos compostos de borracha bromobutílica curados com resina, enxofre e doador de enxofre, irradiados e não irradiados..118 TABELA 15: Variação da massa seca dos compostos de borracha clorobutílica curados com resina, enxofre e doador de enxofre, irradiados e não irradiados..121 TABELA 16: Variação da massa seca do composto de borracha butílica curados com resina, enxofre e doador de enxofre, irradiadas e cisalhadas.

TABELA 17: Variação da massa seca dos compostos de borracha bromobutílica curados com resina, enxofre e doador de enxofre, irradiados e cisalhados.

TABELA 18: Variação da massa seca dos compostos de borracha clorobutílica curados com resina, enxofre e doador de enxofre, irradiados e cisalhados. 
TABELA 20: Nomenclatura das amostras com 100\% de borracha virgem (AM) e das amostras contendo $30 \mathrm{phr}$ de borracha recuperada (RC). 148

TABELA 20: Parâmetros reométricos dos compostos de borracha butílica e halobutílicas com 100 phr de borracha virgem e com 70 phr de borracha virgem + $30 \mathrm{phr}$ de borracha irradiada e cisalhada. 150 TABELA 21: Tempo ( $\left.T_{90}\right)$ e temperatura de vulcanização dos compostos de borrachas butílica e halobutílica contendo 70 phr de borracha virgem e 30 phr de borracha irradiada e cisalhada. 151 TABELA 22: Variação da massa seca dos compostos de borrachas butílicas, bromobutílica e clorobutílica contendo 30 phr de borracha recuperada. 157 


\section{LISTA DE ABREVIAÇÕES, ACRÔNIMOS E SíMBOLOS}

ANIP - Associação Nacional da Indústria de Pneumáticos

ASTM - Sociedade Americana de Testes e Materiais (American Society for Testing and Materials)

BIIR - Borracha bromobutílica

BR - Borracha de polibutadieno

CBS - N-cicloexil benzotiazol 2-sulfenamida

CIIR - Borracha clorobutílica

CONAMA - Conselho Nacional do Meio Ambiente

CR - Borracha de neoprene

DCBS - N-dicicloexil benzotiazol 2-sulfenamida

DMM - Distribuição de massa molar

DSC - Calorimetria diferencial de varredura (Differential scanning calorimetry)

E' - Módulo de armazenamento

E" - Módulo de perda

EDS - Sistema de energia dispersiva

EPDM - Compósitos de borracha de etileno-propileno

ESR - Espectroscopia de ressonância paramagnética (Eléctron Spin Resonance)

FNMA - Fundo Nacional do Meio Ambiente

$\mathrm{G}(\mathrm{S})$ - valores de $\mathrm{G}$ para cisão de cadeia 
$G(X)$ - valores de $G$ para reticulação

GPC - Cromatografia de permeação em gel

GTR - Pó de borracha de pneus

HDPE - Polietileno de alta densidade

HNBR - Borrachas nitrílica hidrogenada

IAEA - International Atomic Energy Agency

IBAMA - Instituto Brasileiro do Meio Ambiente e dos Recursos Naturais Renováveis

IIR - Borracha butílica

MBS - Morfolinotio benzotiazol

MBT - Acelerante do tipo Mercaptobenzotiazol

MBTS - Dissulfeto de dibenzotiazol

MDR - Reômetro de cavidade móvel

MEV - Microscopia eletrônica de varredura

MH - Torque máximo medido no reômetro

ML - Torque mínimo medido no reômetro

MM - Massa molar

NBR - Denominação de norma da Associação Brasileira de Normas Técnicas (ABNT)

NR - Borracha natural

PDMS - Borracha de silicone 
PHR - Partes por 100 partes de borracha, "per hundred of rubber"

PU - Poliuretano

R - Cadeia do polímero

RC - Borracha recuperada

RMN - Ressonância magnética nuclear

SBR - Copolímero de butadieno e estireno

SBR/NR - Copolímero de butadieno e estireno/ borracha natural

t9o - Tempo necessário para que o torque atinja 90\% do torque máximo

TBBS - N-t-butil benzotiazol 2-sulfenamida

TBzTD - Tetrabenziltiuram dissulfeto

Tg - Temperatura de transição vítrea

$t_{M H}-$ Mesmo que $t_{100}$

TMTD - Dissulfeto de tetratiltiuram

TMTM - Monossulfeto de tetratiltiuram

ts1 - tempo, em minutos, necessário para aumentar o torque mínimo ML em uma unidade de torque.

ts2 - tempo, em minutos, necessário para aumentar o torque mínimo ML em duas unidades de torque.

tanঠ - Tangente de delta - relação módulo de perda pelo módulo de armazenamento

UV - Ultravioleta 
Z - Número atômico

ZBDC - Dibenzil ditiocarbamato de zinco

ZBEC - Ditiocarbamato de zinco

ZEDC - Dietil ditiocarbamato de zinco

ZMBT - 2-mercaptobenzotiazol de zinco

ZMDC -Dimetilditiocarbamato de zinco 


\section{INTRODUÇÃO}

Um dos maiores problemas enfrentados na preservação do meio ambiente é o gerenciamento dos resíduos de materiais poliméricos, após o consumo, ou seja, sobras de produção e artefatos usados ${ }^{1}$. A coleta seletiva de lixo é um dos caminhos utilizados para administrar a disposição destes produtos. Porém, a estrutura para tratamento dos resíduos, ainda se baseia na simples destinação à queima (com eventual aproveitamento de energia) ou doação/venda à atividade sucateira, que após a seleção, lavagem e regranulação, os recoloca no mercado para misturar com resinas virgens, barateando, assim, o novo processamento. A atividade deste setor é dirigida aos materiais termoplásticos, que, após novo aquecimento, adquirem comportamento propício à nova extrusão ou injeção ${ }^{2}$.

Este comportamento não é verificado nos polímeros reticulados (termofixos), principalmente nos elastômeros vulcanizados (comumente chamados de borrachas vulcanizadas). Geralmente estes resíduos são queimados, destinados ao aterro sanitário ou utilizados como carga inerte (após moagem e pulverização), em aplicações diversas, ou mesmo no próprio processo que os originou (neste caso, com deterioração das propriedades mecânicas do produto final e com o benefício da redução de custo $)^{1}$.

No Brasil, como no mundo, o destino correto de resíduos sólidos e seus impactos no meio ambiente, é cada vez mais preocupante e tem sido tratado como política pública de estado, acarretando uma mudança comportamental por parte das empresas e da sociedade ${ }^{3}$. No Brasil, a regulamentação da geração, manuseio e reaproveitamento de resíduos está baseada em leis federais, estaduais e municipais, fiscalizadas pelos órgãos governamentais FNMA, IBAMA e CONAMA. As normas ambientais estão previstas na ISO 14.000 e a disposição dos resíduos é regida pela NBR 10.004 (NBR 10004, 1987) ${ }^{4}$. 
Segundo dados da ANIP $^{5}$ (Associação Nacional da Indústria de Pneumáticos), cerca de 60 milhões de pneus são fabricados por ano no Brasil e de acordo com a Reciclanip ${ }^{6}$ (entidade criada pelos fabricantes de pneus para a coleta e destinação), o volume de pneus destinados de 1999 a março de 2012 foi de 2,28 milhões de toneladas coletadas e destinadas, equivalente a 456 milhões de pneus de passeio. Com baixas taxas de reciclagem, as carcaças de pneus são vistas em rios e riachos; vale a pena ressaltar que pneus velhos contribuem para a proliferação de doenças como a dengue ${ }^{7}$.

As borrachas possuem decomposição natural muito lenta ${ }^{8}$, em virtude de sua estrutura química resistente ao intemperismo e à degradação enzimática e microrganismos. A recuperação da borracha é dificultada por sua insolubilidade em virtude de suas estruturas reticuladas ${ }^{9}$. Além disso, esta estrutura tridimensional acarreta diversos problemas para a recuperação e o reprocessamento desse material ${ }^{10}$. Apenas $8 \%$ a $12 \%$ dos resíduos poliméricos são de polímeros termoplásticos; os restantes são elastômeros, representados, principalmente, pelos pneus pós-consumo ${ }^{11}$. É importante salientar que a reticulação é indispensável para a utilização prática da borracha, esse processo é mundialmente conhecido como processo de vulcanização, descoberto pelo norteamericano Charles Goodyear ${ }^{12}$.

Portanto como mencionado anteriormente, a maioria das sobras de borracha, principalmente os pneus, são descartados e dispostos em aterros. Em outras situações, são usados como combustíveis e incinerados para produzir eletricidade; além disso, os custos destas operações são bastante elevados. Outras formas de reaproveitamento das borrachas compreendem: utilização em asfalto, fabricação de sola de sapatos, borrachas de vedação, dutos pluviais, pisos para quadras poli-esportivas, pisos industriais, além de tapetes para automóveis. De acordo com o exposto, a reciclagem e recuperação se apresentam como as melhores opções de gerenciamento destes resíduos ${ }^{1,13}$.

Apesar dos vários processos já desenvolvidos e aplicados para reciclagem de borracha, a viabilização desses processos ainda apresenta vários desafios, tanto de ordem técnica como em relação à qualidade do material 
recuperado, principalmente quanto ao comprometimento da estrutura principal da borracha, responsável pelas propriedades físicas e mecânicas finais dos artefatos $^{1}$.

A recuperação dos produtos de borrachas pode ser realizada por meio dos seguintes processos:

- Processos químicos: são efetuados principalmente em reatores de alta pressão com solventes específicos e altas temperaturas, para aumentar o rendimento das reações ${ }^{1,4}$, Esses processos apresentam a vantagem de possibilitar a quebra seletiva das reticulações polissulfídicas, sem que ocorra uma ruptura significativa da cadeia principal ${ }^{14}$.

- Processos biológicos: são processos seletivos, nos quais as ligações químicas das borrachas vulcanizadas são quebradas e o enxofre é removido por meio de biotratamento com bactérias. Algumas delas têm sido utilizadas, na desvulcanização de NR, SBR e BR, como Nacardia, Thiobacillus e Mycolata, sem causar significativa degradação do hidrocarboneto polimérico. Na literatura, estes métodos são citados como de baixo rendimento de desvulcanização, pois atacam somente a superfície das amostras e ainda não são viáveis de serem aplicados em escala industrial ${ }^{15,16} \mathrm{e}$

- Processos físicos que compreendem os processos:

- Mecânicos (borracha é cisalhada por meio de misturadores abertos)룰

- Termomecânicos (borracha é colocada num solvente apropriado para ser inchada e posteriormente transferida para um cilindro $)^{1}$;

- Crio-mecânicos (borracha é mergulhada em nitrogênio liquido e, micronizada em moinhos de bolas ou martelo $)^{1}$;

- Ultrassom (no intervalo de $16 \mathrm{KHz}$ a $1 \mathrm{MHz}$, a desvulcanização é realizada através da combinação entre a extrusão e aplicação de energia de ultrassom. $)^{12,17,18} \mathrm{e}$ 
- Micro-ondas (com frequências na faixa de $300 \mathrm{MHz}$ a $300 \mathrm{GHz}$, eficaz para realizar a reciclagem de reticulados de borrachas polares, causa a desestabilização da rede tridimensional) ${ }^{19,20}$.

Nos processos físicos apresentados, a maior parte deles gera borracha na forma de um pó, que pode ser utilizado como carga inerte. Portanto é desejável um sistema físico que possibilite a obtenção de borrachas recicladas que funcionem como carga ativa.

Este estudo para recuperação e/ou reciclagem de borrachas utilizou o processamento com raios gama seguido de cisalhamento em cilindro aberto. Especificamente foi estudada a obtenção de borrachas devulcanizadas, que permitem uma nova reticulação (ou vulcanização). 


\section{OBJETIVO}

O objetivo geral deste trabalho foi desenvolver um processo de degradação controlada (desvulcanização) para compostos de borrachas butílicas e halobutílicas (cloro e bromo), por meio da degradação induzida via radiação, visando posteriormente o reaproveitamento.

O objetivo específico foi estudar o efeito da interação da radiação ionizante em compostos de borrachas butílicas e halobutílicas. Analisar a influência da halogenação das borrachas butílicas e também dos diferentes sistemas de cura das composições desenvolvidas, após a irradiação

A degradação induzida por radiação ionizante da borracha foi avaliada conforme a alteração de suas propriedades, tais como: tração, alongamento, dureza, e propriedades reológicas, etc. A borracha desvulcanizada por degradação induzida via radiação foi testada para reuso na formulação original da mistura de borracha, em substituição a algumas partes da borracha virgem na confecção de novos compostos.

\subsection{Originalidade do tema}

Em vários trabalhos de diferentes autores, foram pesquisados métodos de degradação induzida por radiação de borracha butílica e halobutílicas virgem e de restos de pneus. Até o presente momento, não existe nenhum trabalho de irradiação em borrachas butílicas e halobutílicas com base em formulações criadas pelo autor, que compare o efeito da irradiação entre estes compostos e seus diferentes sistemas de cura. 


\section{FUNDAMENTOS TEÓRICOS}

\subsection{Borrachas}

As borrachas são materiais de natureza polimérica que possuem como principal característica a elasticidade, podendo, em condições normais, deformarse e rapidamente voltar ao seu estado inicial. Esses materiais são comumente conhecidos como elastômeros ${ }^{21}$.

As borrachas são compostas por uma sequência repetitiva de um ou mais tipos de monômeros ${ }^{22}$. Estruturalmente possuem alta massa molar, formadas por emaranhados de longas cadeias de macromoléculas, como se observa na FIG. 1.

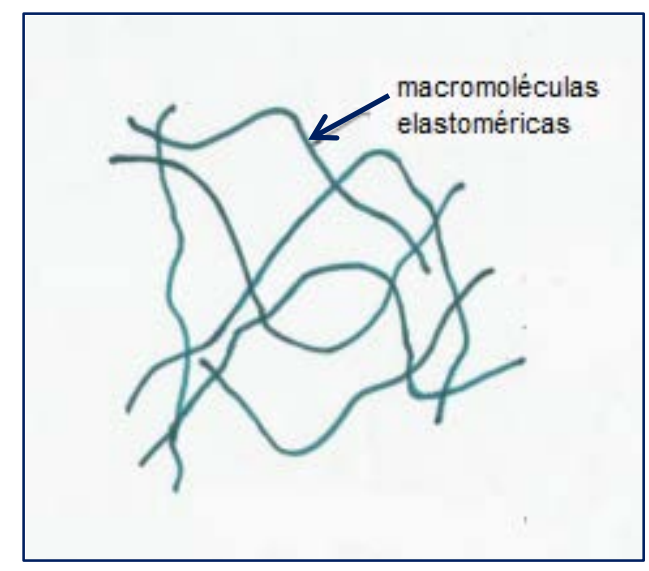

FIGURA 1: Esquema da estrutura da borracha não vulcanizada ${ }^{22}$.

As borrachas são classificadas em dois grandes grupos:

- Naturais (NR), nome químico (cis e trans poliisopreno), é obtida a partir de seringueiras onde a principal representante é a Hevea brasiliensis;

- Sintéticas a partir de derivados de petróleo e com diversas formulações ${ }^{23,24}$. 
Atualmente existem mais de 500 tipos e variedades de borrachas, classificadas em aproximadamente 20 grupos $^{25}$. A borracha tornou-se, uma das mais importantes matérias primas utilizadas em nível industrial. Seu emprego tem crescido tanto em qualidade como em diversidade. Os conjuntos de características exibidos pelos diferentes tipos de borracha viabilizam um mercado diversificado, englobando desde a fabricação de pneus até aplicações em peças cirúrgicas e equipamentos industriais tais como correias transportadoras e de transmissão, absorvedores de impacto, solas de calçados, entre muitos outros ${ }^{26}$.

\subsubsection{História da borracha}

Antes do descobrimento das Américas, a borracha era uma substância totalmente desconhecida do velho mundo. Colombo em sua segunda viagem à América (1493-1496) informou ter observado os índios jogarem com bolas elásticas. A borracha era usada também em roupas (para torná-las impermeáveis), como espécies primitivas de botinas, em vasilhames flexíveis e seringas ${ }^{27}$.

A utilização mundial da borracha foi atingida devido ao engenheiro francês Condamine que em 1735, conclui que a borracha da Guiana Francesa era "uma espécie de óleo resinoso condensado". O primeiro emprego da borracha proposto por Magellan foi como apagador. O inglês Priestley difundiu este uso e foi dado à borracha o nome de Índia Rubber, que significa Borracha da Índia ${ }^{28}$.

Macquer, retomando os trabalhos de Condamine, propôs a fabricação de tubos flexíveis de borracha. Em 1820, um industrial inglês chamado Nadier, fabricou fios de borracha e utilizou-os como acessórios de vestuário. Assim, começou a reinar na América a "febre" da borracha, com a produção de tecidos impermeáveis e botas de neve ${ }^{29}$. Entretanto, todos esses produtos eram influenciados pelo frio, tornando-se quebradiçosno frio e pegajosos quando expostos ao calor ${ }^{30}$. Além disso, produziam odores desagradáveis após um curto período de tempo ${ }^{31}$. 
Essas deficiências foram superadas quando Hayward (1838) descobriu que, a partir da mistura de enxofre com borracha e exposição posterior à luz solar (processo de solarização)m, a superfície do composto deixava de ser pegajosa. Foi a partir desta descoberta que Charles Goodyear, em 1839-1840, na tentativa de desenvolver um processo para aperfeiçoar a qualidade da borracha (com a incorporação de ácido nítrico $-\mathrm{HNO}_{3}$ ), descobriu acidentalmente que, após a adição de enxofre à borracha, sob aquecimento, era obtida uma goma elástica que não esfarelava e nem colava. Este processo foi denominado "vulcanização" 32 e foi patenteado por Goodyear em $1844^{33}$. Paralelamente, Thomas Hancok aparentemente desconhecedor da descoberta de Goodyear, patenteou na Inglaterra e publicou em 1843 um processo semelhante ${ }^{34}$.

O termo vulcanização foi inventado e sugerido a Hancok por Willian Brockedon e tem origem na mitologia romana (Vulcano, Deus do fogo); é usado para descrever o processo pelo qual a borracha reage com enxofre para produzir uma rede de ligações cruzadas e artefatos de forma rígida, impossível de ser moldado, porém ainda flexível e elástico. Goodyear empregava a palavra "cura" para descrever o mesmo processo. De qualquer forma atualmente, vulcanização e cura são utilizadas como sinônimos quando aplicadas à borracha ${ }^{35}$.

\subsubsection{Vulcanização}

Para que a borracha possa ter uma aplicação industrial é necessário que seja submetida ao processo de vulcanização. As propriedades físicas dos materiais elastoméricos tais como: módulo, dureza, resiliência, alongamento, geração de calor entre outras, são basicamente definidas, durante o processo de vulcanização, em função das ligações cruzadas entre as cadeias da borracha ${ }^{36}$.

A vulcanização é um processo de reticulação pelo qual a estrutura química da borracha, é alterada pela conversão das moléculas do polímero, numa rede tridimensional. A vulcanização converte um emaranhamento viscoso de moléculas com cadeia longa numa rede elástica tridimensional (FIG. 2), unindo quimicamente (reticulação) estas moléculas em vários pontos ao longo da cadeia $^{22}$. 
(a) Fluido viscoso

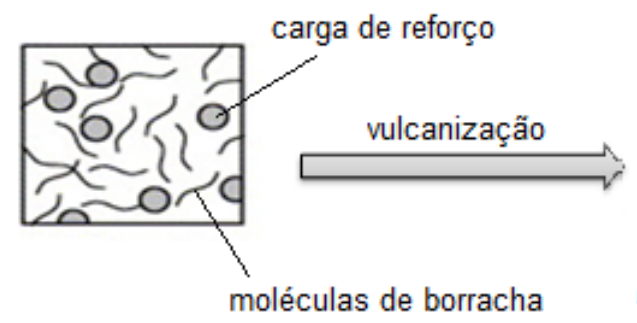

material não curado (b) Solido elástico

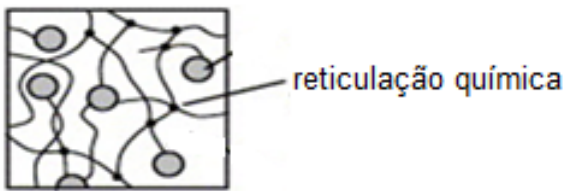

material curado

FIGURA 2: Modelo molecular do processo de vulcanização ${ }^{37}$.

Resumindo os elastômeros são redes de cadeias de polímeros unidos por meio de ligações cruzadas; cuja força resistente às deformações é proporcional ao número de reticulações por unidade de volume. A vulcanização é o processo químico capaz de produzir a união entre as cadeias de polímeros pela inserção de ligações cruzadas na cadeia polimérica ${ }^{38}$.

Segundo Costa $^{34}$ e colaboradores (2003), a rede de ligações cruzadas formadas pela vulcanização, sem aceleradores ou em presença de aceleradores inorgânicos (em geral óxidos metálicos tais como óxidos de zinco, cálcio, magnésio ou chumbo) é muito complexa. A vulcanização com enxofre e sem aceleradores gera além dos diferentes tipos de ligações cruzadas com enxofre, grande proporção de modificações na cadeia principal como: ciclizações sulfídicas, insaturações conjugadas, e isomerização cis/trans da dupla ligação. Portanto. a vulcanização com enxofre sem a presença de aceleradores é, um processo ineficaz ${ }^{22}$. As ligações cruzadas introduzidas com maior frequência em borrachas são obtidas a partir da utilização de enxofre ${ }^{36}$ ou peróxidos ${ }^{39}$.

\subsubsection{Vulcanização por enxofre}

O enxofre (S) foi o primeiro agente de vulcanização utilizado, em seu estado elementar e, também com estrutura molecular em forma de anel com oito elementos $\left(\mathrm{S}_{8}\right)$. A vulcanização de elastômeros com enxofre e sem aceleradores pode ocorrer conforme observado na FIG. 3, onde a vulcanização da borracha é realizada com a adição de enxofre, sob aquecimento, e na presença de catalizadores. Nesse processo, os atómos de enxofre tomam lugar dos 
hidrogênios alílicos (hidrogênio ligado ao carbono vizinho ao carbono que possui a dupla ligação); esta nova estrutura permite que as moléculas deslizem uma sobre as outras. Com a vulcanização, os átomos de enxofre ligam as macromoléculas umas as outras, formando pontes de enxofre que aumentam a resistência e a dureza da borracha. A vulcanização com enxofre é mais comumente aplicadas na reticulação de borrachas insaturadas ${ }^{40}$.

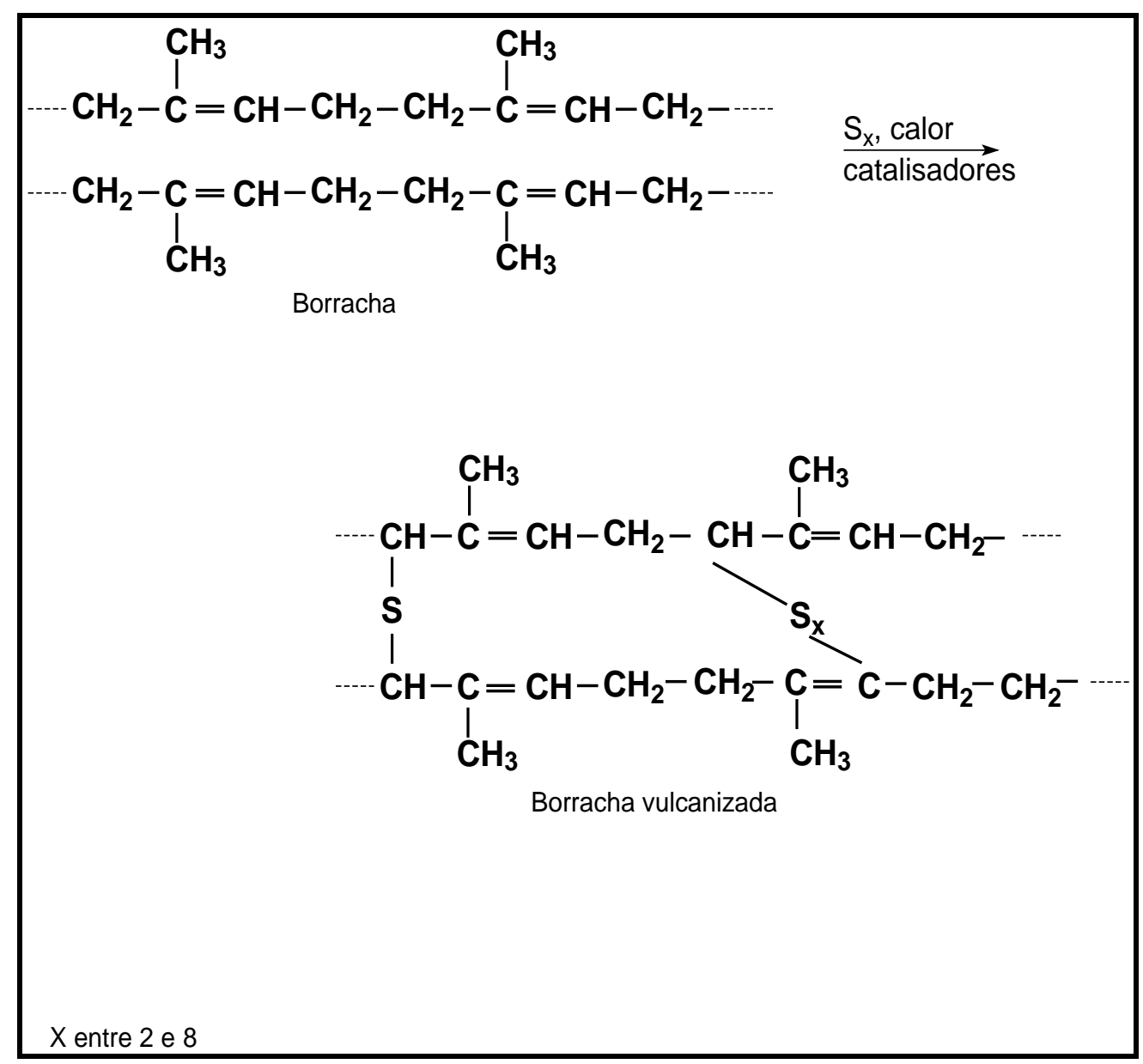

FIGURA 3: Reações de vulcanização de elastômero utilizando enxofre sem a presença de aceleradores ${ }^{36}$.

O processo de vulcanização com enxofre sem aceleradores é demorado, o que torna inviável sua aplicação para fins industriais. A reação de vulcanização é determinada pela temperatura e tempo de vulcanização. 


\subsubsection{Vulcanização com enxofre e aceleradores orgânicos}

A partir da descoberta dos aceleradores orgânicos em aproximadamente 1900, o tempo de vulcanização da borracha foi reduzido, com isso, houve uma maior aplicação industrial, pois o uso de aceleradores permitiu o aumento da velocidade de vulcanização e o emprego de temperaturas mais baixas $^{27}$.

Os principais tipos de aceleradores geralmente utilizados na vulcanização de elastômeros com enxofre são mostrados na FIG. 5.

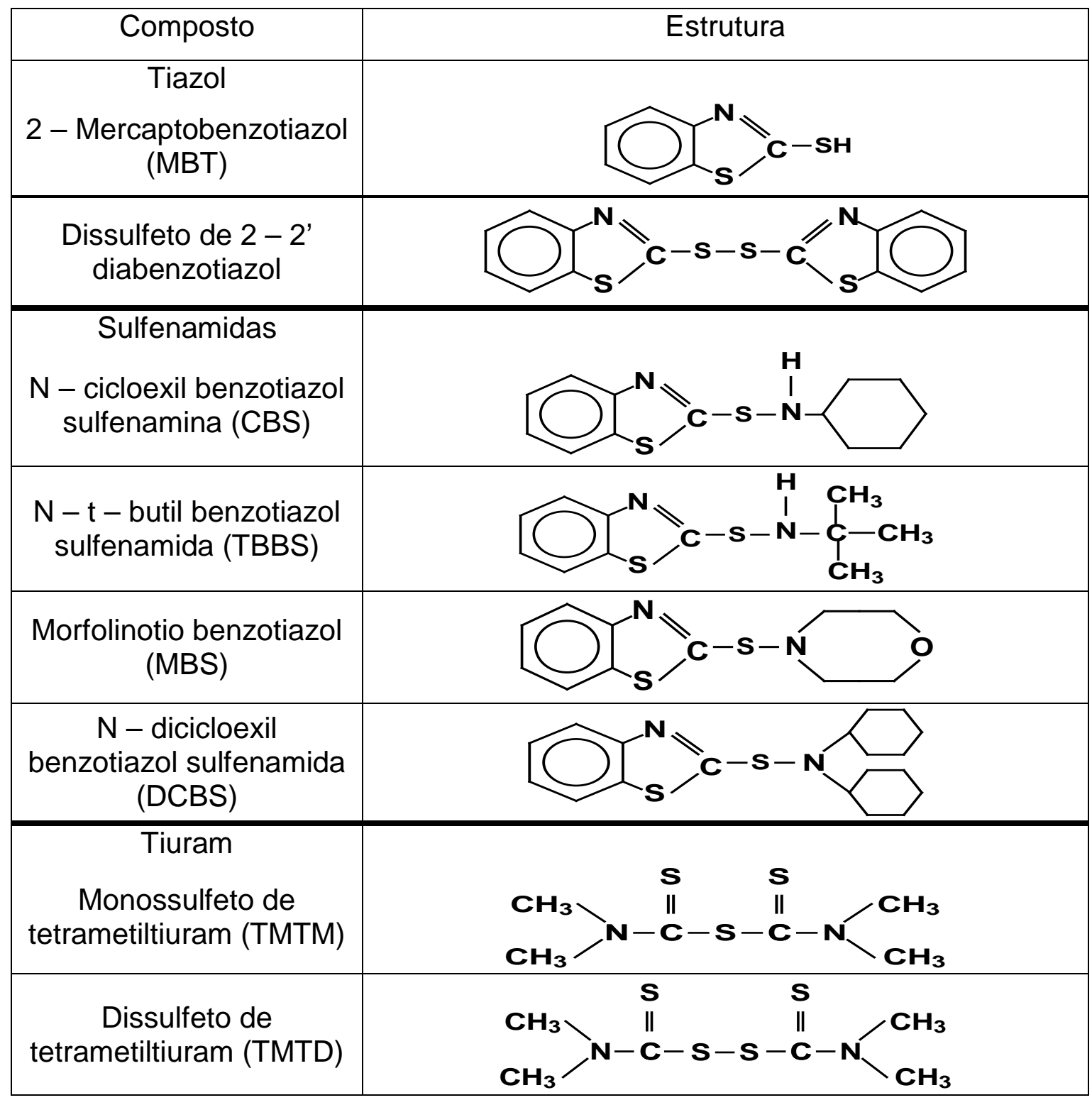

FIGURA 4: Principais aceleradores utilizados na vulcanização de elastômeros com enxofre ${ }^{40}$. 
A rede de ligações cruzadas derivada da vulcanização em presença de aceleradores orgânicos é mais simples e com menos modificações do que a rede produzida somente com o enxofre, daí o processo ser chamado de eficiente ${ }^{41}$.

Os sistemas de vulcanização com enxofre são classificados de acordo com a quantidade relativa de enxofre e aceleradores orgânicos utilizados, bem como o tipo de ligação sulfídica predominante após a vulcanização.

- Monossulfídicas (-C-S-C-): quando um átomo de enxofre se liga a duas cadeias poliméricas através de duas unidades de isopreno. Este sistema proporciona ao artefato maiores propriedades dinâmicas e de flexão, mas menor resistência térmica e à reversão ${ }^{1}$. Ao aumentar a quantidade de acelerador, a quantidade de enxofre deve diminuir para se obter a mesma densidade de reticulação. Consequentemente são formadas reticulações com menor número de átomos de enxofre.

- Dissulfídicas (-C-S $-\mathrm{C}-$ ): quando dois átomos de enxofre ligam duas cadeias por meio de duas unidades de isopreno. Como consequência, são obtidos vulcanizados, com excelente resistência ao calor e à reversão, mas menor resistência à fadiga.

- Polissulfídicas (-C-S $-\mathrm{C}-$ ): quando mais de dois átomos de enxofre ligam duas cadeias poliméricas por meio de duas unidades de isopreno. Estes sistemas conferem aos vulcanizados boas propriedades mecânicas e dinâmicas, além de propriedades intermediárias de resistência ao calor e reversão ${ }^{42}$.

Na FIG. 5 estão mostrados, os vários tipos de ligações que o enxofre pode estabelecer entre as cadeias macromoleculares de borracha.

\footnotetext{
${ }^{1}$ Reversão é a degradação térmica das ligações polisulfídicas, causando a redução da densidade de reticulação, a mudança na distribuição dos tipos de ligações e a modificação na estrutura da cadeia principal.
} 


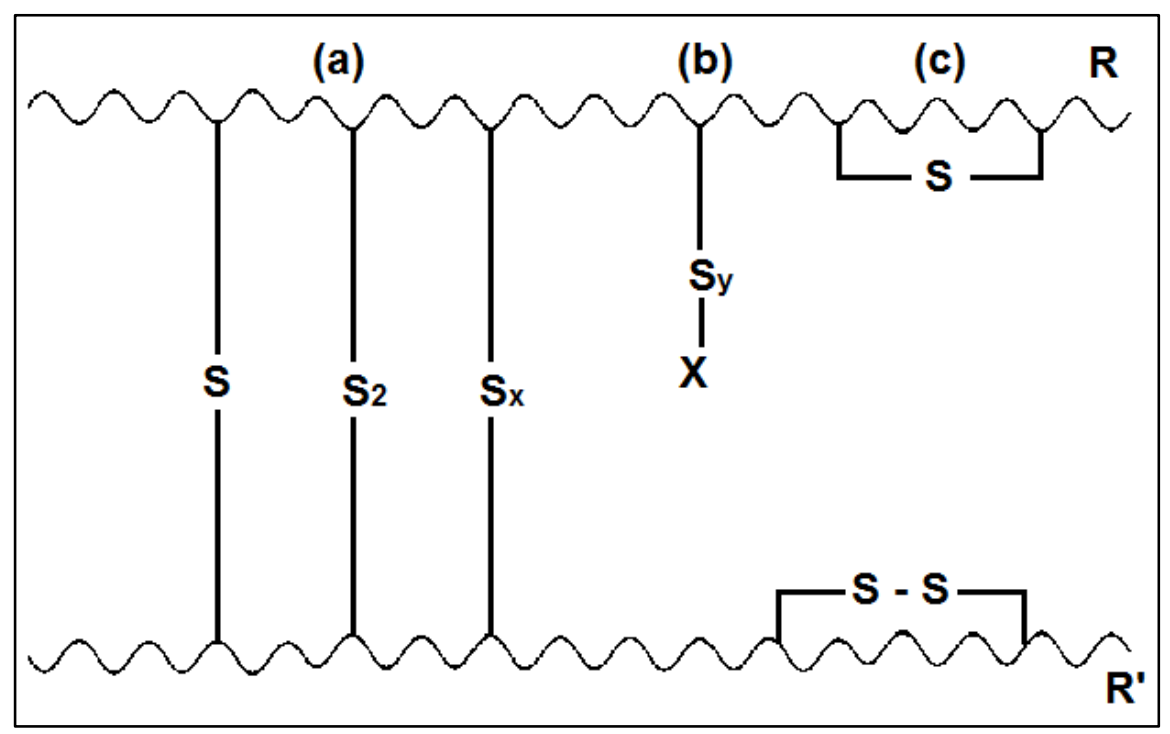

FIGURA 5: Tipos de ligações estabelecidas na vulcanização com enxofre (a) ligação na cadeia principal de duas macromoléculas de borracha (b) ligação em que o enxofre e o acelerador estão ligados à cadeia principal; (c) ligações mono e dissulfídica cíclicas (extra reticulares) ${ }^{43}$.

As ligações dissulfídicas e polissulfídicas resultam da relação entre 0 enxofre e o acelerador utilizado ${ }^{44}$. De acordo com estudos realizados por Bin Chung e Miller (2001) ${ }^{45}$ a razão entre as quantidades de enxofre e de acelerador de um composto elastomérico influência o sistema de reticulação, bem como os tipos de ligações cruzadas (monossulfídicas, dissulfídicas e polissulfídicas). Além de influenciar as propriedades do produto final, afeta diretamente sua processabilidade em virtude da modificação do tempo de pré-vulcanização, assim como o tempo máximo que a composição pode ser exposta à temperatura de processo, sem a formação de um teor de ligações cruzadas que comprometam o comportamento reológico e a processabilidade.

O processo de vulcanização com acelerador e enxofre é descrito na FIG.6. Um complexo ativo do acelerador é formado pela interação preliminar entre o acelerador e o oxido de zinco ( $\mathrm{ZnO})$, na presença de zinco solúvel. Esse complexo pode reagir com o enxofre molecular, mediante a abertura do anel de $\mathrm{S}_{8}$, para formar um agente sulfurante ${ }^{34}$. Posteriormente, o agente sulfurante pode reagir com as cadeias de borracha para formar um precursor de ligações cruzadas. O precursor foi detectado por evidências experimentais na forma de um polissulfeto, ligado a um fragmento da molécula do acelerador, e está presente como grupo pendente na cadeia principal de borracha. 
O precursor, posteriormente, conduz à formação de ligações cruzadas polissulfídicas. Ocorre então, a diminuição de eficiência na formação de ligações cruzadas devido a reações laterais, como decomposição ou dessulfurização (diminuição do tamanho das ligações cruzadas, eventualmente levando a ligações monossulfídicas) dos precursores ${ }^{46,47}$. Devido a estas reações laterais, a formação de sulfetos cíclicos, dienos conjugados, trienos, sulfeto de zinco (ZnS), e grupos monossulfídicos pendentes pode ser observada.

Estas espécies são incapazes de contribuir para a geração de ligações cruzadas. Foi verificado que a atividade, a concentração do complexo zincoacelerador e a temperatura são as principais variáveis de controle para as possíveis reações laterais citadas ${ }^{48}$.

Finalmente, a rede de ligações cruzadas formada inicialmente sofre maturação e, durante esse processo, ocorre a dessulfurização (diminuição do tamanho das ligações cruzadas, eventualmente levando a ligações monossulfídicas) e/ou a decomposição das ligações cruzadas polissulfídicas ${ }^{48}$. 


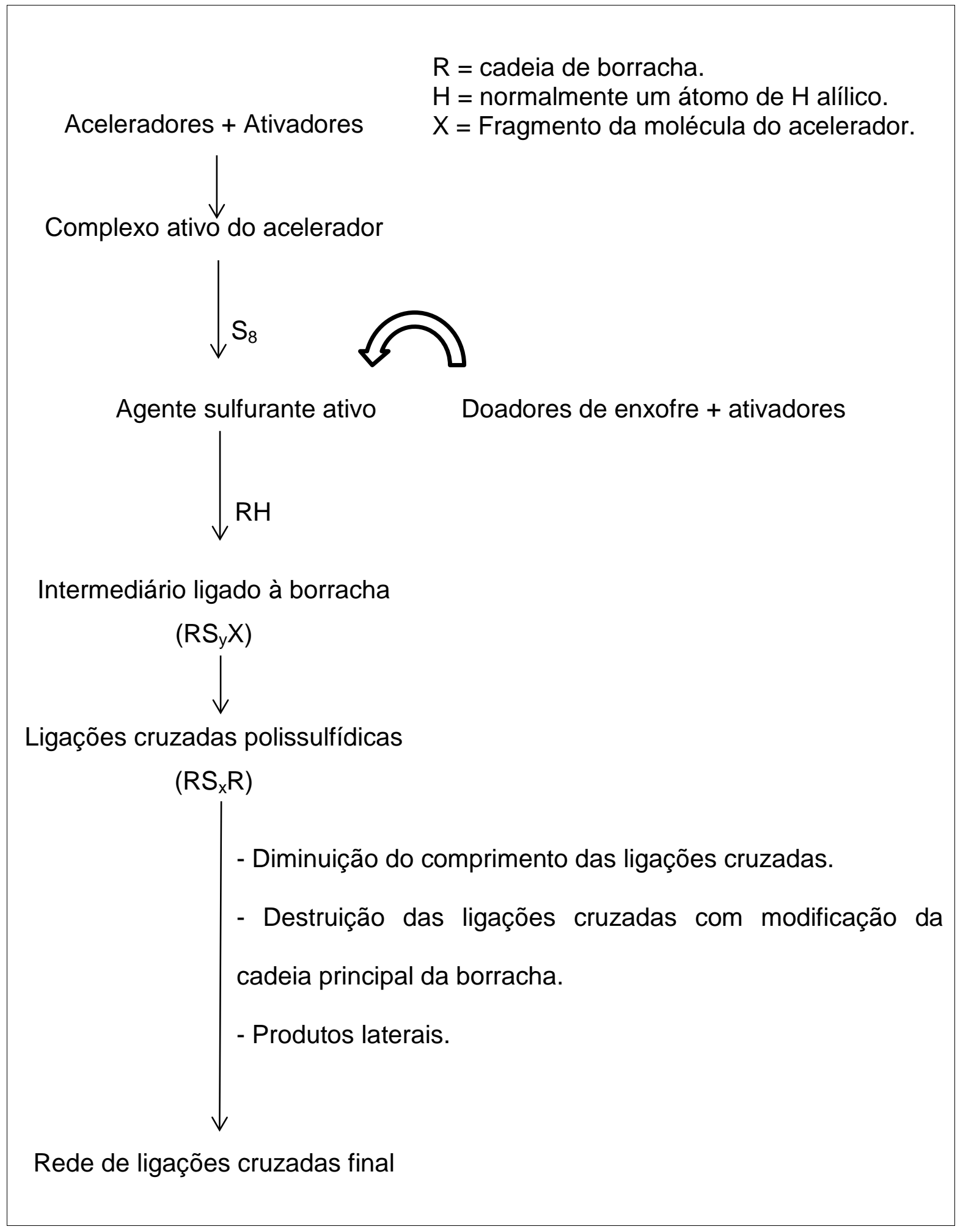

FIGURA 6: Rota geral para o processo de vulcanização com acelerador e enxofre ${ }^{48}$.

Os aceleradores, por serem doadores de enxofre, promovem no elastômero uma determinada característica de reticulação, diferente da obtida ao utilizar enxofre $^{49}$. O comportamento do elastômero varia em razão da natureza das ligações cruzadas formadas. O tipo, a densidade e a distribuição das ligações 
cruzadas são muito importantes na determinação das propriedades de um composto de borracha ${ }^{39}$. A influência do teor de ligações cruzadas nas propriedades mecânicas das composições de borrachas vulcanizadas ${ }^{50}$ pode ser observada na FIG. 7. E também a dependência das propriedades de um vulcanizado em virtude da densidade de reticulação, pois o aumento de ligações cruzadas pode favorecer um conjunto de propriedades, como resistência ao rasgo; e ser pior para outras, como a histerese que é a relação entre o componente viscoso e o elástico da resistência à deformação. Esta é também uma medida da energia de deformação a qual não é armazenada, mas sim convertida em calor ${ }^{51}$.

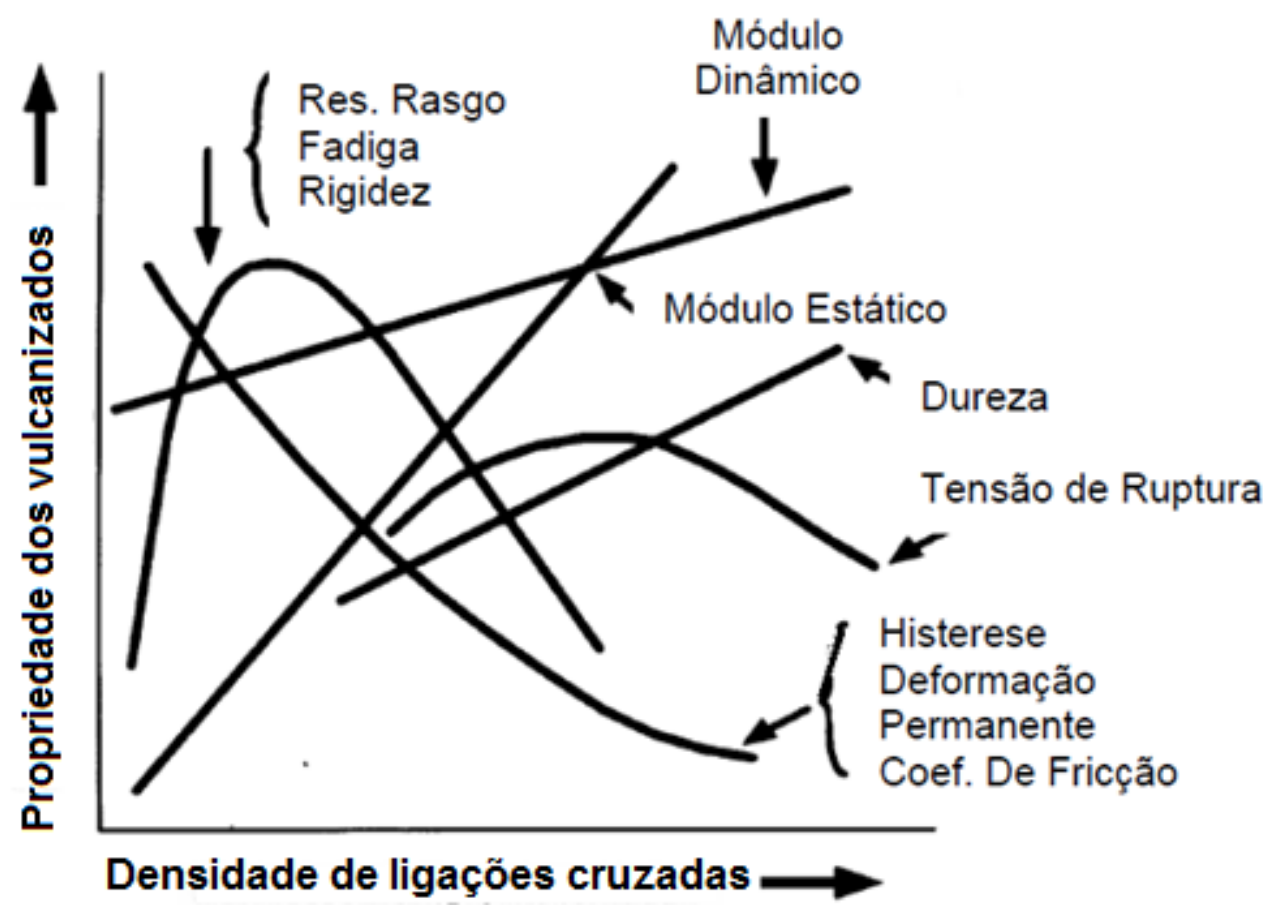

FIGURA 7: Variação de propriedades de um elastômero vulcanizado em função da formação de ligações cruzadas ${ }^{50}$.

Com o aumento da formação de ligações cruzadas, a massa molar aumenta, e podem aparecer ramificações na cadeia molecular e uma distribuição de massa molar maior, ocorrendo um acréscimo na força de coesão. Nota-se que a tensão de ruptura e resistência ao rasgo aumenta com o acréscimo da densidade de reticulação até um valor máximo, e chega-se a um ponto em que 
estas propriedades decaem com a formação de ligações cruzadas. Com o aumento destas ligações os movimentos moleculares diminuem e as estruturas tridimensionais, não conseguem mais dissipar energia em forma de calor. Consequentemente há um decréscimo da tensão de ruptura das cadeias, com baixos alongamentos.

As resistências ao rasgo e à fadiga estão relacionadas com a energia de ruptura; assim estes valores aumentam com pequenas quantidades de reticulação, mas diminuem à medida que a densidade de ligações aumenta.

O módulo elástico (rigidez) aumenta com o número de ligações cruzadas por unidade de volume, a estrutura tridimensional torna-se mais resistente à deformação sob tensão, o que exige maior esforço para uma dada deformação. Como excesso de reticulação, a estrutura de ligações cruzadas é degradada, reduzindo assim o módulo (como acontece com borracha natural) ${ }^{52,53}$. Cada uma dessas propriedades está associada à quantidade de ligações cruzadas presentes na cadeia polimerica, e também o tipo de ligação formada ${ }^{54}$.

De acordo com a relação enxofre e aceleradores presente na formulação, os sistemas de vulcanização podem ser classificados comoconvencional, semi-eficiente e eficiente ${ }^{55}$, conforme a TAB.1.

TABELA 1: - Sistemas de vulcanização à base de enxofre e acelerador ${ }^{56}$.

\begin{tabular}{|c|c|c|c|c|}
\hline Tipo & $\begin{array}{c}\text { Nível enxofre } \\
\text { (phr) }\end{array}$ & $\begin{array}{c}\text { Nível } \\
\text { acelerador } \\
\text { (phr) }\end{array}$ & $\begin{array}{c}\text { Relação } \\
\text { Acelerador/ } \\
\text { Enxofre (phr) }\end{array}$ & $\begin{array}{c}\text { Relação } \\
\text { Enxofre/ } \\
\text { Acelerador } \\
\text { (phr) }\end{array}$ \\
\hline Convencional & $2,0-3,5$ & $1,2-0,4$ & $0,1-0,6$ & $1,7-8,8$ \\
\hline $\begin{array}{c}\text { Semi-eficiente } \\
\text { (SEV) }\end{array}$ & $1,0-1,7$ & $2,4-1,2$ & $0,7-2,5$ & $1,4-0,4$ \\
\hline Eficiente (EV) & $0,4-0,8$ & $5,0-2,0$ & $2,5-12$ & $0,08-0,4$ \\
\hline
\end{tabular}

A sigla phr significa partes (do ingrediente) por 100 partes de borracha (parts per hundred rubber), é o sistema adotado pelas indústrias de borracha para 
dosar os componentes das formulações (ingredientes) ${ }^{57}$. O componente principal é a borracha; desta forma, ficou convencionado que a quantidade dos outros ingredientes está sempre relacionada à quantidade de borracha.

A estabilidade destes sistemas (convencional, semi-eficiente e eficiente) é variável; quanto maior o número de átomos de enxofre maior é facilidade de cisão dessas ligações, como no processo de envelhecimento. Isto está relacionado com a energia de ligação dos átomos, conforme demonstrado na TAB. 2. Existem duas teorias: a da formação de radicais livres e a da formação de compostos intermédios de natureza iônica. A estrutura tridimensional das ligações cruzadas depende da escolha do sistema de vulcanização, ou seja, da quantidade de enxofre, ativadores e aceleradores da formulação. O sistema convencional possui maior quantidade de enxofre, se comparado com os outros sistemas; a possibilidade de formação de grandes quantidades de ligações polissulfídicas é maior neste sistema ${ }^{49}$.

TABELA 2: Valores de energia para ligações cruzadas em elastômeros ${ }^{58}$.

\begin{tabular}{|c|c|}
\hline Tipo de ligação cruzada & Energia de ligação* $\left(\mathrm{kJ} \mathrm{mol}^{-1}\right)$ \\
\hline - C - C - & 347 \\
\hline - C - S - C - & 280 \\
\hline - C - S - S - C - & 262 \\
\hline - C - S - C - & $<262$ \\
\hline
\end{tabular}

* Estes valores sofrem pequenas variações, de acordo com as ligações adjacentes.

Conforme citado anteriormente, a escolha do sistema de cura impacta diretamente em dois fatores: velocidade ou cinética de vulcanização e tipo e forma das ligações cruzadas, influenciando as propriedades do produto final ${ }^{59}$.

\subsubsection{Cinética de vulcanização}

A vulcanização dos elastômeros ocorre por uma combinação dos aditivos de vulcanização, temperatura, pressão e tempo, portanto conhecer a cinética de vulcanização de um composto de borracha significa conhecer a curva 
de vulcanização em função do tempo, sob determinadas condições de pressão e temperatura.

A reometria de disco oscilatório é empregada para avaliar esses parâmetros. A combinação de agentes de vulcanização, aceleradores, ativadores, tipo de elastômero, teor de cargas reforçantes e outros aditivos da formulação do composto elastomérico são caracterizados por meio da curva reométrica.

Neste ensaio, a amostra é mantida numa cavidade fechada sob pressão e alta temperatura, simulando a vulcanização. Envolve um disco bicônico que oscila com pequeno arco. Esta ação exerce uma deformação cisalhante e a força é proporcional à rigidez da amostra na amplitude máxima de deslocamento (torque).

As taxas de vulcanização dos composto de borracha são desenvolvidas em consequência do tempo e temperatura na qual são expostos ${ }^{60}$. Estas mudanças geralmente ocorrem em três estágios: período de indução; estágio de cura ou vulcanização e estágio de reversão ou sobrecura ${ }^{61,62}$. Como mostra a FIG.8.

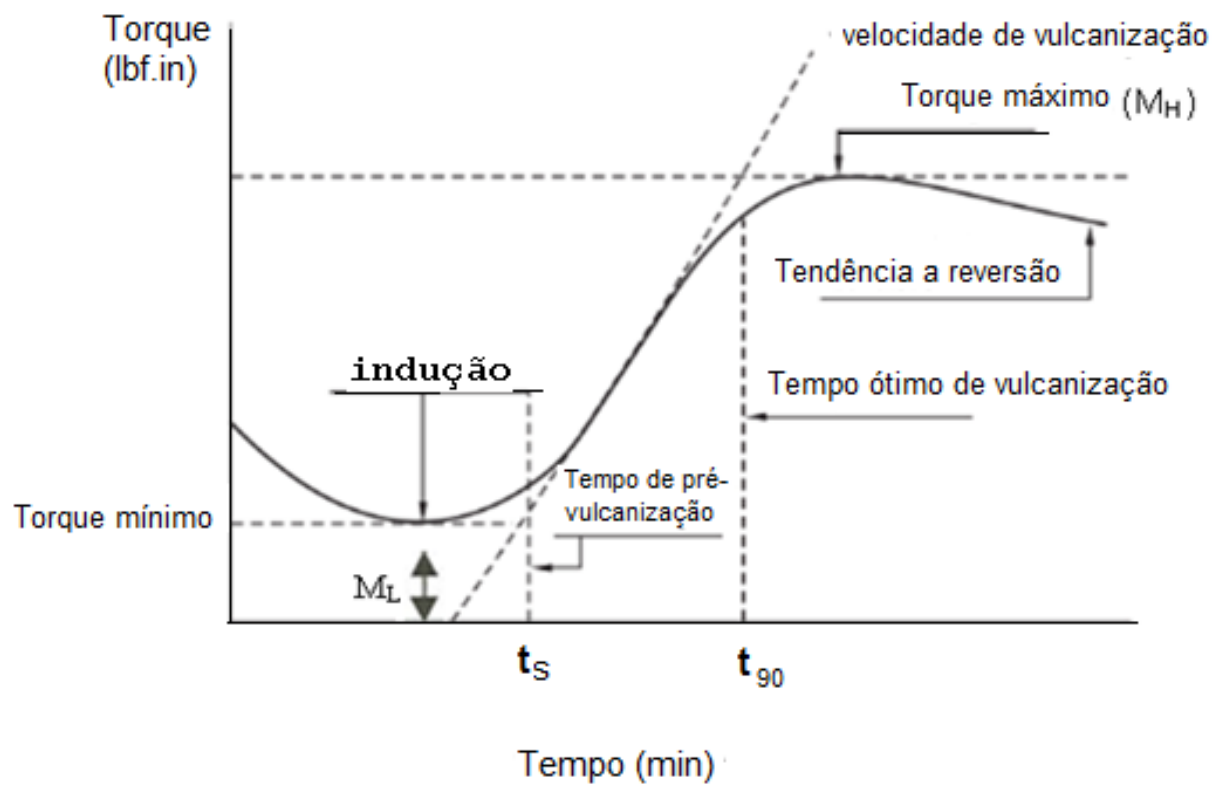

FIGURA 8: Curva típica de uma análise por reômetro de disco oscilatório ${ }^{61}$. 
As principais informações fornecidas pelo equipamento são: torque mínimo (ML), que fornece as caracteristicas viscosas da mistura não vulcanizada; torque máximo $(\mathrm{MH})$, que indica o máximo de reticulação alcançada; tempo de pré-cura $\left(T_{S}\right)$, que é o tempo disponível até o inicio das reações de vulcanização e ( $\left.T_{90}\right)$, que é o tempo a $90 \%$ do valor de torque máximo ${ }^{63}$, também chamado de tempo ótimo de vulcanização e pode ser obtido pela EQ 1.

$$
\mathrm{T}_{90}=(\mathrm{MH}-\mathrm{ML}) \times 0,9+\mathrm{ML}
$$

Pode-se identificar também na FIG.8, as três fases encontradas na vulcanização de um composto de borracha. A indução que representa o tempo, na temperatura de vulcanização, durante o qual não ocorre formação das ligações cruzadas $^{64}$. Após o período de indução, há a formação das ligações cruzadas em uma velocidade dependente da temperatura, do tipo de borracha e do sistema de cura empregado. À medida que os aditivos do sistema de cura são consumidos, as reações de vulcanização tornam-se lentas até que uma rigidez ótima é atingida. Este ponto representa a vulcanização completa. O aquecimento adicional pode favorecer um aumento muito lento ou decréscimo da rigidez, dependendo do tipo de borracha utilizada. Estas mudanças finais são conhecidas como sobrecura, no qual as ligações começam a se romper e o composto perde propriedades $^{65}$.

\subsection{Borracha butílica e halobutilica}

\subsubsection{Borracha butílica}

A borracha butílica (IIR) é um copolímero de isobutileno (98\%) e de isopreno (2\%); começou a ser produzido comercialmente em $1942^{66}$. Em sua cadeia hidrocarbonada (FIG. 9), o nível de insaturação é muito baixo, o que lhe confere excelente resistência ao envelhecimento, baixa permeabilidade a gases, boa estabilidade térmica, elevada resistência à ação do oxigênio, ozônio, radiação solar e excelente resistência à umidade e ao ataque de substâncias químicas ${ }^{67,68}$. Tem sido empregada em uma grande variedade de aplicações tais como: pneus 
(câmaras de ar, revestimento interno de pneus, etc.) e artefatos diversos (tampas, vedações, etc.) ${ }^{69}$.

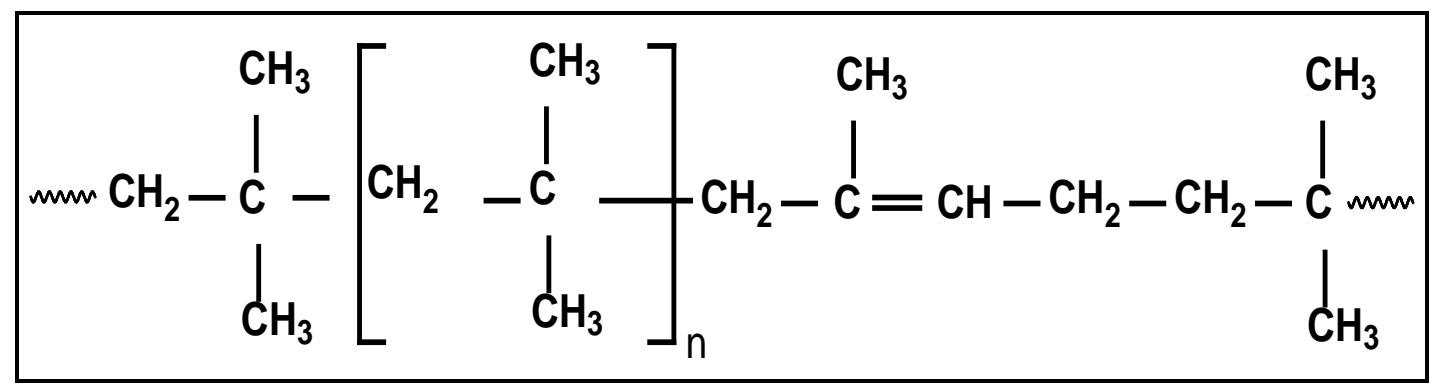

FIGURA 9: Ilustração da estrutura da borracha butílica

A borracha butílica pode ser vulcanizada por três métodos básicos ${ }^{70}$ :

- Vulcanização com enxofre e aceleradores;

- Vulcanização com quinona dioxima;

- Vulcanização com resina.

\subsubsection{Borrachas butílicas halogenadas}

\subsubsection{Borracha bromobutílica}

A borracha bromobutílica (BIIR) é um copolímero de isobutileno e isopreno, contendo 1,9 a $2,1 \%$ de bromo $^{71}$. Devido à alta saturação da cadeia principal da borracha bromobutílica, sua cura pode ser mais complexa do que as borrachas de uso geral, como elastômeros de borracha natural ou de polibutadieno. Possuem outras aplicações além de utilização em câmaras de ar de pneus, tais como: paredes laterais do pneu, montagem de motores automotivos, para fins especiais, capas de correia transportadora, e aplicações farmacêuticas $^{72}$. A vulcanização da borracha bromobutílica, pode ser realizada pelos seguintes métodos:

- Vulcanização com enxofre;

- Vulcanização isenta de zinco, com diaminas;

- Vulcanização com resina;

- Vulcanização com peróxido ${ }^{73}$. 


\subsubsection{Borracha clorobutílica}

A borracha clorobutílica (CIIR) é um copolímero de isobutileno e isopreno contendo 1,1 a 1,3 \% de cloro. Esta borracha também possui alta saturação da cadeia principal, permitindo a confecção de produtos de borracha com excelentes propriedades, como: amortecimento de vibrações, baixa transição vítrea, resistência às baixas temperaturas, baixa permeabilidade a gases, e resistência ao envelhecimento quando exposta a condições atmosféricas. A presença da insaturação olefínica e de cloro reativo no butil clorado proporciona uma grande variedade de técnicas de vulcanização ${ }^{70}$. A vulcanização da borracha clorobutílica pode ser realizada pelos seguintes métodos ${ }^{74}$.

- Vulcanização com óxido de zinco;

- Vulcanização com resina;

- Vulcanização com dissulfureto de alquil fenol;

- Vulcanização com amina e tiouréia;

- Vulcanização a baixa temperatura (cloreto de zinco ou cloreto estanhoso (1 phr) com enxofre e ditiocarbamatos, tiurans e tiouréias).

A halogenação da borracha butílica (FIG.10) tem por finalidade criar outros pontos de reatividade nas unidades funcionais da borracha butílica e aumentar as possibilidades de vulcanização, inclusive com agentes de vulcanização como o óxido de zinco e resinas fenólicas ${ }^{75}$.

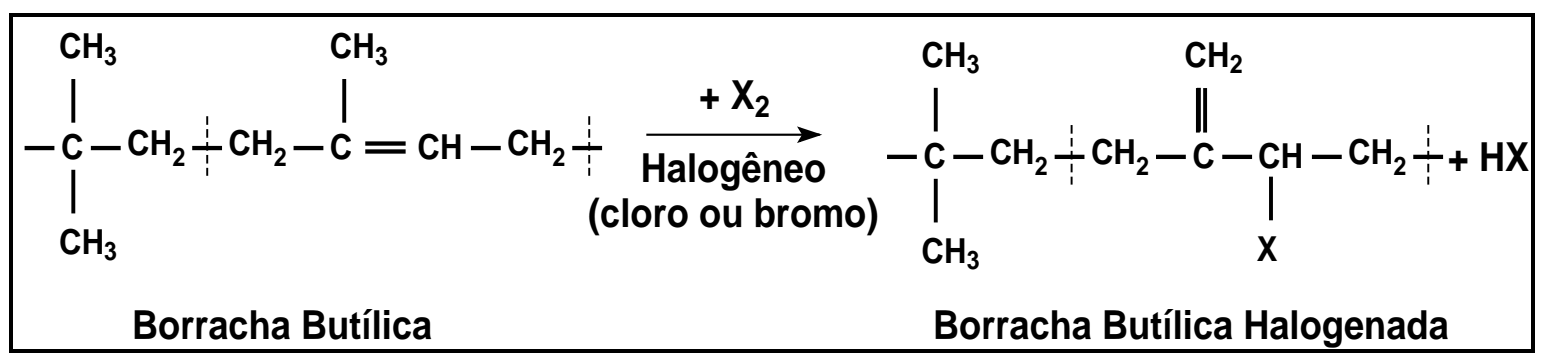

FIGURA 10: Estrutura da borracha butílica halogenada 


\subsubsection{Vulcanização da borracha butílica e butílica halogenada}

Em virtude do baixo grau de insaturação na estrutura polimérica das borrachas butílicas, é necessário o emprego de agentes de cura mais rápidos, como os tiurans ou tiocarbamatos. As resinas fenólicas e os derivados de quinona também podem ser usados. A reticulação química promovida pela vulcanização introduz ligações covalentes ao longo da cadeia molecular. As reticulações polissulfídicas possuem baixa estabilidade em altas temperaturas e em muitos casos podem sofrer um novo rearranjo na forma de reticulação monossulfídicas e dissulfídica, que se tornam permanentes quando submetidos a altas temperaturas por um longo período de tempo. No sistema de cura por resina fenólica os vulcanizados são mais estáveis a altas temperaturas ${ }^{76,77}$.

As borrachas butílicas halogenadas podem ser vulcanizadas com os mesmos agentes de cura das borrachas butílicas, como óxido de zinco, ditiazóis, sulfenamidas e tiurans. Os halogênios são átomos que são substituídos nas reações de reticulação devido à baixa energia de ligação entre carbono e halogênio (TAB. 3) em relação a energia de ligação entre C-C. As principais diferenças entre a borracha bromobutílica e a borracha clorobutílica ${ }^{71,}$ encontrase na maior versatilidade na vulcanização, isto é:

- Maior possibilidade de escolha nos agentes de vulcanização;

- Vulcanização mais rápida, em geral;

- Menor ts 2 em geral;

- Necessidade de menor quantidade de agentes de vulcanização.

- Elevada tendência para covulcanização com borrachas de elevada insaturação.

Em alguns casos nos compostos butílicos halogenados é indispensável à adição de óxido de magnésio ativo ou estearato de cálcio para neutralizar os gases ácidos gerados durante a vulcanização, dos halogêneos existentes no polímero $^{78}$. 
TABELA 3: Energia e Comprimento das ligações entre carbono e halogênio ${ }^{79}$

\begin{tabular}{|c|c|c|}
\hline Ligação & Energia kJ/mol & $\begin{array}{c}\text { Comprimento } \\
\text { (nm) }\end{array}$ \\
\hline - C - C - & 347 & 0,154 \\
\hline - C - H & 413 & 0,109 \\
\hline- C - F & 434 & 0,138 \\
\hline- C - Cl & 327 & 0,177 \\
\hline- C - Br & 281 & 0,194 \\
\hline
\end{tabular}

As aplicações de maior utilidade das borrachas butílicas consistem em revestimento interno de pneus, câmaras de ar e tampas farmacêuticas ${ }^{80}$. A escolha do sistema de cura depende do emprego do produto final.

\subsubsection{Mecanismo de vulcanização com resina}

Compostos de borracha butilica curados com resina podem exibir melhor resistência aos efeitos prejudiciais da exposição a altas temperaturas em comparação com as borrachas butilicas vulcanizadas com enxofre, que tendem a amolecer durante exposição prolongada a temperaturas elevadas $\left(150^{\circ} \mathrm{C}\right.$ $\left.200^{\circ} \mathrm{C}\right)$.

A cura dos compostos de borracha butílica com resina depende da reatividade do grupo fenil-metilol da resina de octil formol-formaldeído ${ }^{70}$. Em virtude do baixo nível de insaturação da borracha butílica a cura com resina requer a adição de um ativador que contenha grupos halogenados em sua composição e capaz de doar halogênios, como a borracha de policloropreno ${ }^{81}$.

Neste caso, a borracha de policloropreno não é considerada como ingrediente da formulação; esta borracha age como ativador de cura, pois o óxido de zinco presente na formulação reage com o halogênio da borracha de cloropreno para formar haleto de zinco que atua como catalizador de vulcanização na cura da borracha butílica com resina ${ }^{81}$.

A estrutura genérica do octilfenol para-terciário das resinas de cura é mostrada na FIG.11. As características principais destas resinas são suas 
estruturas fenólicas poliméricas, contendo o grupo octil terciário na posição parafenólica e o grupo terminal metilol.

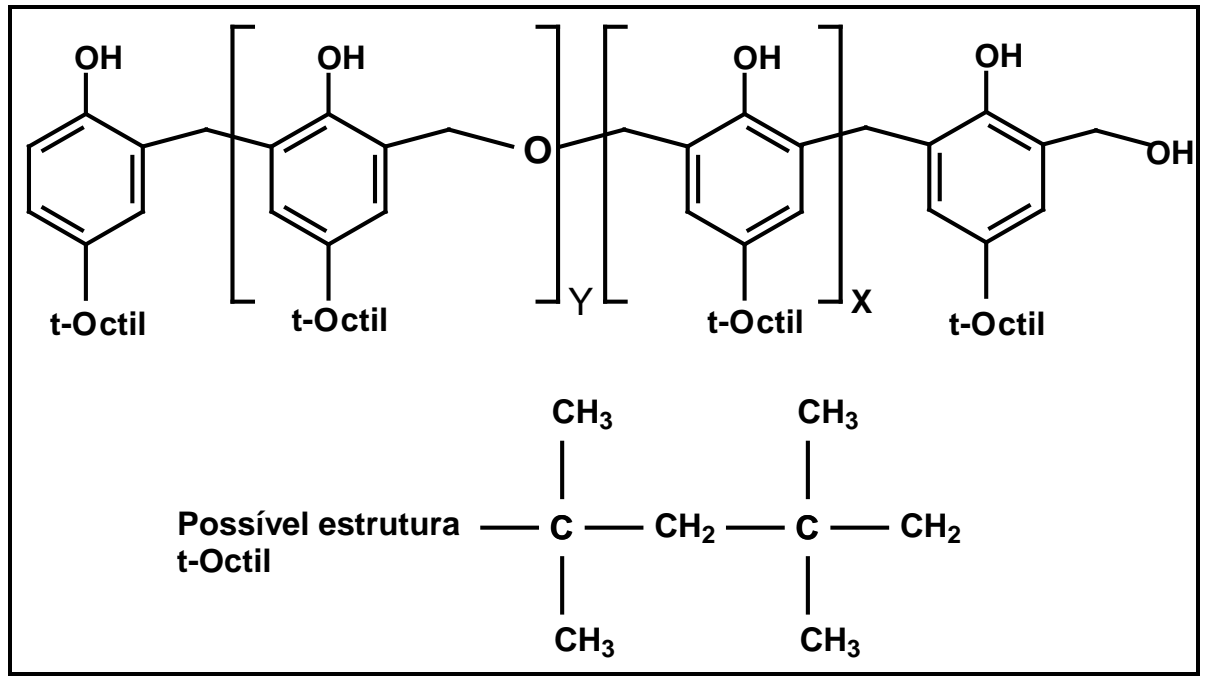

FIGURA 11: Estrutura genérica da resina de cura (resina de octil formolformaldeído) ${ }^{81}$.

Supõe-se que a cura por resinas ocorra pela formação de um éter cíclico via reação entre seus grupos fenólicos (resina) e a cadeia isoprênica insaturada da borracha butílica (FIG. 12). Como mencionado anteriormente, os sistemas de cura por resina necessitam de um doador de halogênio para formação de haletos de zinco que reagem com os grupos terminais $\mathrm{OH}$, para aumentar a reatividade da resina. Estas reações adicionais resultam numa taxa de cura muito lenta ${ }^{81}$.

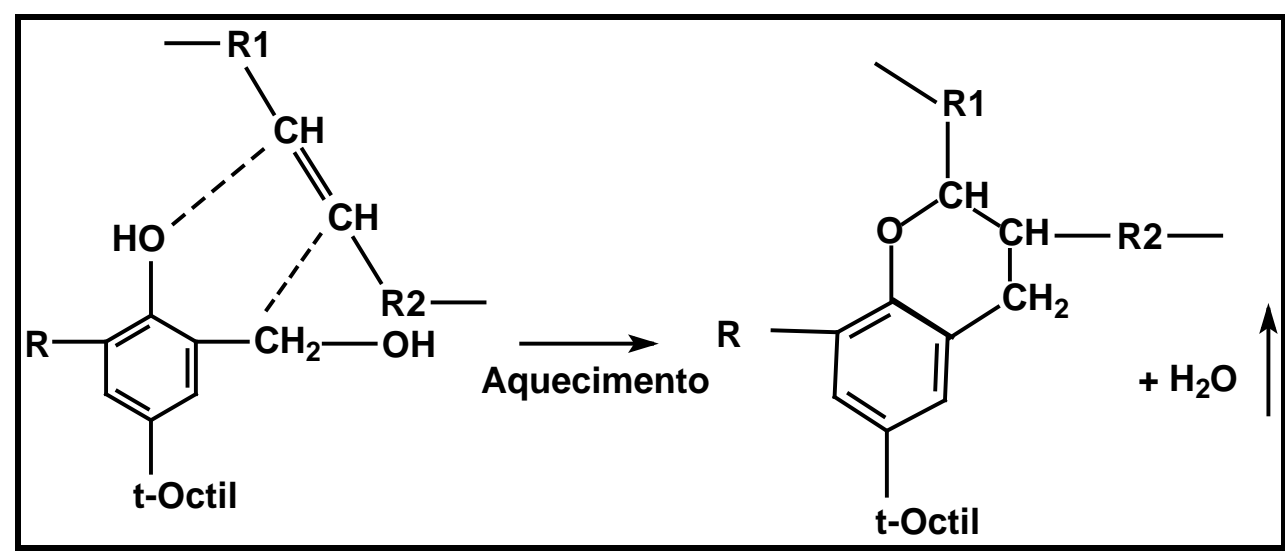

FIGURA 12: Reação da resina de cura com as duplas ligações do C-C da cadeia polimérica $^{81}$. 
A vulcanização com resina ocorre quando os anéis da cadeia fenólica se ligam aos grupos metilenos da cadeia polimérica. Os grupos terminais metilol $\left(-\mathrm{CH}_{2} \mathrm{OH}\right)$ são os pontos em que a molécula de resina se liga com a molécula do polímero butílico. O hidrogênio que está ligado ao carbono da dupla ligação reage com o $\mathrm{OH}$ do grupo metilol, estabelecendo uma ligação entre carbono-carbono (C-C) entre as moléculas da borracha butílica e a resina. A reação de reticulação é formada quando essas ligações ocorrem nas extremidades da molécula da resina ${ }^{82}$. O mecanismo de cura envolve tanto as hidroxilas fenólicas como as hidroxilas do grupo metilol numa reação de substituição através da dupla ligação, resultando numa estrutura cíclica, como mostra a FIG. 12.

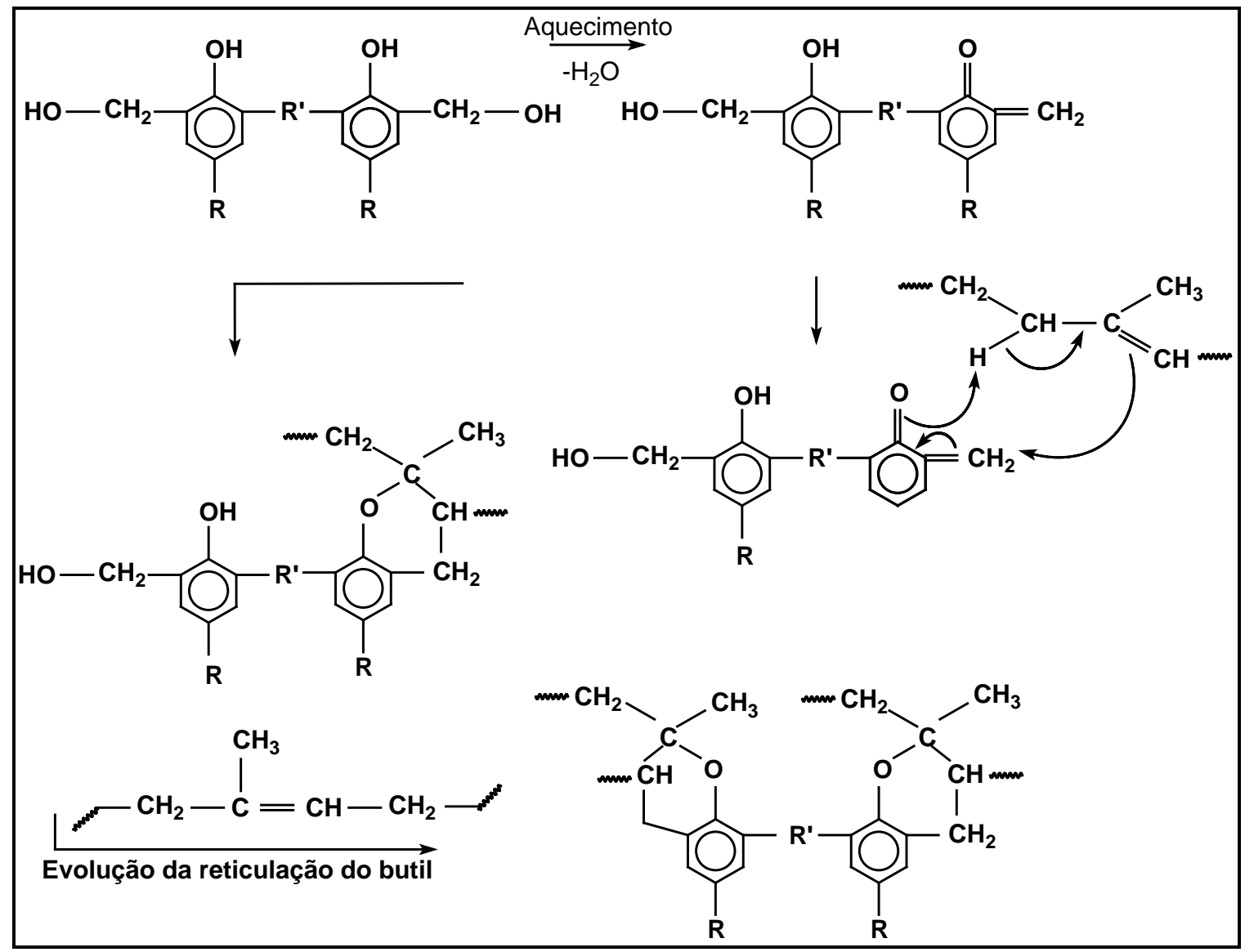

FIGURA 13: Resumo do esquema da reação da borracha butílica curada com resina.

O mecanismo de reação de cura por resina da borracha butílica é ilustrado no FIG. 13. Observa-se que, após a eliminação da água, o grupo hexametileno e o oxigênio do grupo carbonila reagem com a unidade de isopreno 
da borracha butílica, para formar uma cadeia cíclica, estas estruturas são bastante estáveis ${ }^{63}$.

\subsubsection{Mecanismo de vulcanização com enxofre e aceleradores.}

A borracha butílica pode ser reticulada com enxofre e ativada com óxido de zinco e aceleradores orgânicos, pois possui baixo grau de insaturação em sua cadeia. São obtidos estados de vulcanização adequados, somente com aceleradores muito ativos como os tiurans e ditiocarbamatos ${ }^{70}$, que viabilizam a atividade primária de aceleração, tornando o enxofre mais eficiente.

Quando uma mistura de borracha com enxofre é submetida à ação do calor, os átomos de enxofre atacam a dupla ligação e estabelecem, mediante ligações do tipo covalente, pontes de átomos de enxofre entre as cadeias moleculares, formando uma rede tridimensional (FIG. 14). O enxofre tem o papel de agente de vulcanização ${ }^{83}$.

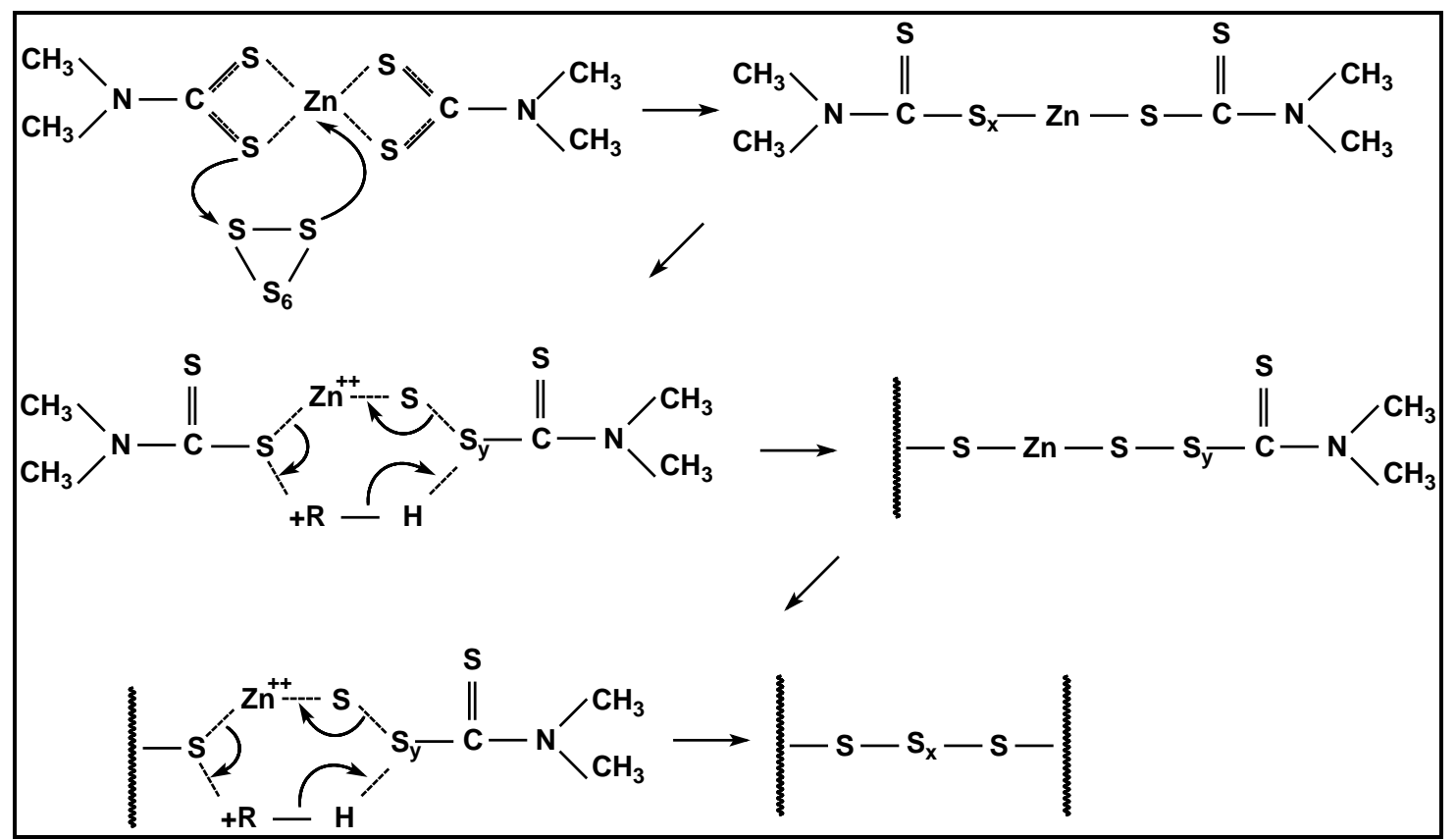

FIGURA 14: Possível mecanismo de vulcanização das borrachas butílicas com agente de cura do tipo tiuram (TMTD $)^{40}$. 


\subsubsection{Vulcanização com doadores de enxofre.}

$\mathrm{Na}$ ausência de enxofre, podem-se utilizar agentes de cura que são doadores de enxofre, como por exemplo, o TMTD (tetrametil tiuram), que aumenta o grau de cura do composto de borracha sem perdas significativas de propriedades $^{40}$. Outros agentes de cura podem ser utilizados tais como MBTS (mercaptobenzotiazol), ZBEC (ditiocarbamato de zinco) e TBzTD (tetrabenziltiuram dissulfeto) $^{84}$. A FIG. 15 ilustra o mecanismo de reação de vulcanização das borrachas butílicas usando os tiurans como doadores de enxofre.

Os agentes de cura do tipo tiurans (TMTD, TMTM) e ditiocarbamatos (ZMDC, ZBDC, ZEDC) são usados como componentes na vulcanização das borrachas butílicas. Os aceleradores a base de tiurans participam do processo de vulcanização através da formação de um complexo de zinco. Ricos complexos de enxofre são formados pela inserção do enxofre pela molécula de zinco dimetil carbamato (ZMDC), na sequência, ocorrem ligações intermediárias e reticulações polissulfídicas. Essas reações envolvem também reticulações monossulfídicas e dissulfídicas ${ }^{40}$.

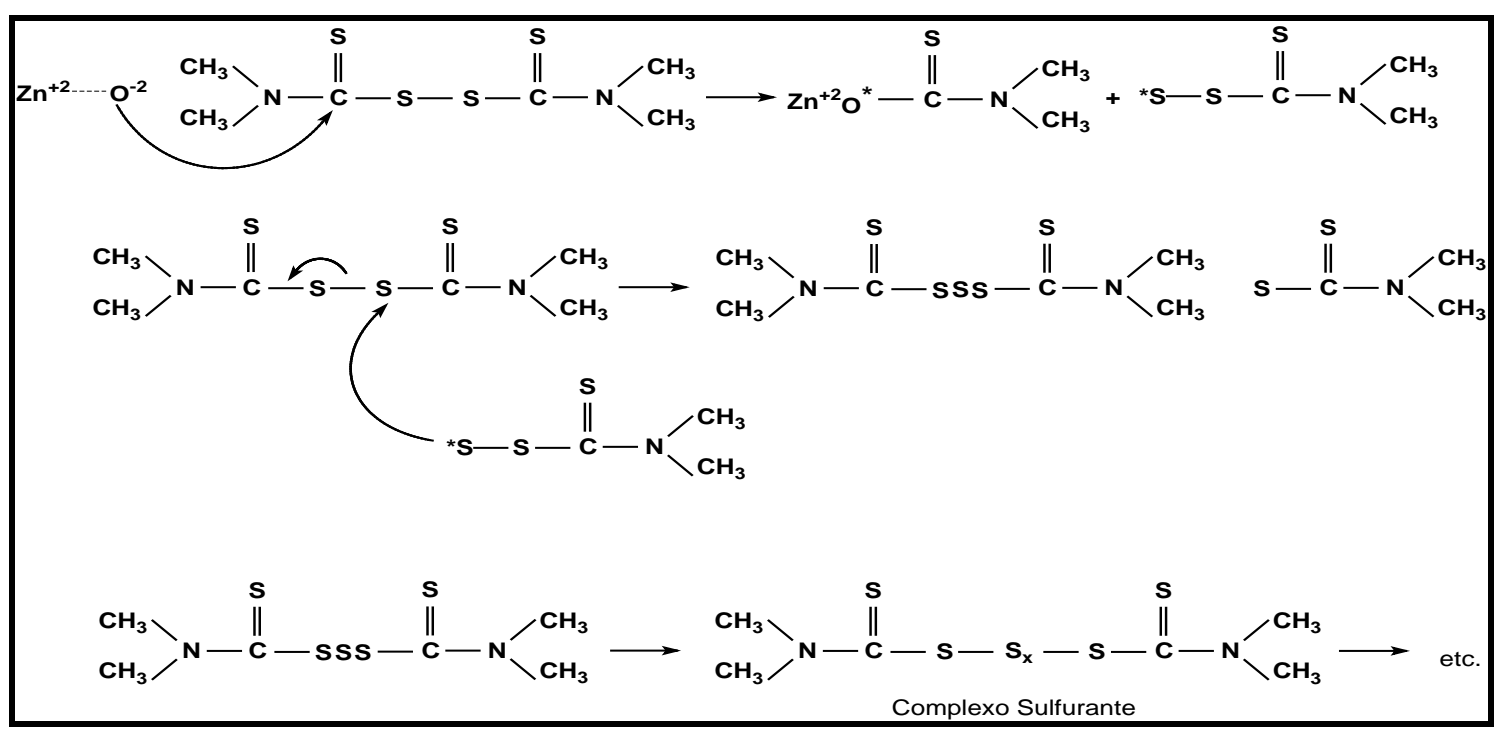

FIGURA 15: Esquema de reação de vulcanização das borrachas butílicas usando tiurans como doadores de enxofre ${ }^{40}$. 


\subsection{Reaproveitamento/Reciclagem de borrachas}

A reciclagem da borracha preserva o meio ambiente, evita a degradação do solo e reduz os impactos negativos sobre a natureza, impedindo que substâncias altamente tóxicas da borracha entrem em contato com a terra ou com as águas, deteriorando esses ambientes a longo prazo. A reciclagem de materiais elastoméricos pode atingir a taxa de 100\% de aproveitamento, dependendo das técnicas de recuperação.

A borracha obtida com base nos métodos de reciclagem pode ser aproveitada para confecção de novos produtos, como artigos de decoração, componentes e ferramentas. O Brasil e alguns países recorrem à borracha reciclada misturada a outros materiais de construção, tais como: concreto e cimento, para a pavimentação de rodovias, ruas e estradas de alto tráfego, diminuindo a abrasão do pneu dos carros com o pavimento ${ }^{85}$.

A desvulcanização da borracha tem sido amplamente estudada, com o objetivo de romper as ligações cruzadas carbono-enxofre (C-S) e enxofre-enxofre $(\mathrm{S}-\mathrm{S})^{1}$. A borracha desvulcanizada pode substituir partes da borracha virgem, em alguns casos, na formulação de um composto, sem alterar significativamente as propriedades e ainda diminuir os custos de produção ${ }^{86}$.

A estrutura molecular da borracha devulcanizada é diferente da estrutura molecular da borracha não vulcanizada. A desvulcanização promove uma série de modificações no material, o que lhe confere propriedades únicas, diferentes das propriedades da composição de borracha antes da vulcanização ${ }^{87,88}$. A borracha devulcanizada apresenta a formação de estruturas secundárias na cadeia do polímero, devido à quebra das ligações químicas e o consequente aparecimento de radicais livres; a formação de ramificações; e a diminuição da massa molar do polímero. Essas modificações na estrutura polimérica da borracha devulcanizada afetam as propriedades mecânicas e reológicas dos compostos que contêm este tipo de borracha. Além disso, as condições de revulcanização contribuem para influenciar a mudança na massa molar ${ }^{8}$. 
É necessário realizar uma caracterização completa destes materiais, para permitir um conhecimento teórico dos processos que ocorrem durante a desvulcanização, e ampliar a faixa de possíveis aplicações deste material.

No processo de recuperação, a cadeia macromolecular da borracha é transformada em pequenos fragmentos de baixa massa molecular, de maneira que ela possa ser facilmente misturada com borracha virgem, para a formação do composto ${ }^{1}$.

Roy ${ }^{89}$ et al, em 1990 desenvolveram um processo de recuperação de borrachas via decomposição térmica sob baixa pressão. Verificaram também a possibilidade de recuperar materiais reaproveitáveis dos pneus, a partir de um reator em escala, de bancada, para processar uma unidade de borracha e o desenvolvimento de uma planta-piloto para testar e desenvolver pirólise a vácuo de pneus usados. Os rendimentos dos materiais recuperados foram: $55 \%$ de óleo, $25 \%$ de negro de fumo, $9 \%$ de aço, $5 \%$ de fibra e $6 \%$ de gás. 0 processo foi testado numa unidade piloto de $200 \mathrm{~kg} / \mathrm{h}$ e mostrou de forma positiva a possibilidade de alimentar continuamente grandes pedaços de borracha sob vácuo. A viabilização do processo foi promissora, com retorno estimado sobre 0 investimento de $31 \%$, depois de três anos de funcionamento.

Binglin $^{90}$ et al, em 1993 usaram o cobalto-60 como fonte de radiação de raios-y para recuperar mais de 400 toneladas de BIIR provenientes de câmaras de pneus; as borrachas foram irradiadas com doses de 45 a 100 kGy. A borracha butílica recuperada foi misturada com borracha butílica virgem, e o composto produzido foi usado para fabricar câmaras e revestimento interno de pneus. A borracha recuperada, sem mistura ou misturada com o copolímero de etileno propileno pode ser usada para produzir materiais de construção à prova d'água. A borracha recuperada mostrou-se estável e de excelente qualidade. Os produtos produzidos com borracha butílica recuperada por radiação gama e misturados com borracha butílica sem irradiação apresentaram valores de tensão de ruptura $>7,5 \mathrm{MPa}$, alongamento $>400 \%$, extrato de acetona $<6 \%$, propriedades similares às encontradas nos compostos fabricados com borracha butílica virgem. Além disso, o composto de borracha butílica virgem misturada 
com a borracha butílica irradiada apresentou melhor desempenho nos processos de mistura e extrusão e diminuição no tempo de vulcanização. O estudo mostrou que o método de radiação- $\mathrm{Y}$ pode ser usado para recuperação de borracha butílica, em substituição aos métodos convencionais. A vantagem apresentada pelo método de radiação consiste na excelente e estável qualidade da borracha butílica recuperada, que pode substituir partes de borracha virgem na fabricação de produtos de borracha. A aplicação de raios- $\gamma$, utilizando como fonte de radiação o cobalto-60, oferece a vantagem de irradiar produtos de borracha de espessura e dimensões consideráveis, por possuírem forte poder de penetração, evitando assim o pré-tratamento, principalmente o corte de pedaços de borracha. A degradação da borracha foi controlada por meio da dose absorvida. Esse processo também não oferece nenhuma poluição ao meio ambiente e ainda economiza energia.

Isayev $^{91}$ et al, em 1995, desenvolveram uma tecnologia para desvulcanização de resíduos de borrachas. A tecnologia foi baseada na utilização dos ultrassom de alta potência. As ondas de ultrassom de certos níveis, na presença de pressão e calor rompem a rede de ligações tridimensionais das borrachas reticuladas. A borracha devulcanizada pode ser reprocessada, moldada e revulcanizada de maneira similar a borracha virgem. O primeiro reator de laboratório foi projetado para ser usado em uma planta-piloto pela National Feedscrew and Machining, Inc. Vários experimentos foram realizados com a borracha de estireno-butadieno (SBR) e com o pó de borracha de pneu (GRT). O comportamento de cura, as propriedades reológicas, e as características estruturais das borrachas devulcanizada em diversas condições de processamento foram estudadas, assim como as propriedades mecânicas de amostras de borrachas revulcanizadas. O possível mecanismo de desvulcanização foi discutido. As análises realizadas indicaram que as borrachas estavam parcialmente desvulcanizada, e o processo de desvulcanização causou certo grau de degradação nas cadeias macromoleculares. Apesar destas observações, as propriedades mecânicas do revulcanizado foram consideradas boas. 
Manuel $^{92}$ et al, em 2000 descreveram uma aplicação para a borracha butílica reciclada. As sobras de borrachas foram misturadas com óleo capaz de inchar a borracha, a mistura foi colocada por algumas horas em autoclave a vapor sob pressão. Após esse processo a mistura é colocada em uma extrusora e peneirada para eliminar a contaminação. A desvantagem desse processo está na dificuldade em controlar as reações, especialmente as de oxidação que acabam por afetar as propriedades físicas da mistura, tais como tensão de ruptura. A borracha butílica reciclada foi testada em dois compostos diferentes de câmaras de pneus. A adição de 20 phr de borracha butílica reciclada em substituição a borracha virgem em compostos de borracha halobutílicas usadas para fabricar pneus aumentou a viscosidade do composto, mas não alterou o tempo total de vulcanização e melhorou o processamento da mistura. As propriedades mais importantes para um revestimento de pneu tais como: impermeabilidade, resistência ao envelhecimento, resistência à fadiga foram melhoradas. A redução na permeabilidade permite diminuir a espessura da parede do pneu, atenuando desta forma o gasto com matéria-prima, no caso da adição de 30 phr de borracha butílica, a economia pode atingir aproximadamente $10 \%$ do custo total. Portanto, a borracha butílica recuperada é uma matéria-prima valiosa na composição do revestimento interno de pneu.

Teinov $^{68}$ et al, em 2002 estudaram métodos de radiação para modificação de materiais poliméricos, como por exemplo, a borracha butílica utilizada na indústria de pneus. A degradação via radiação em polímeros que contêm um átomo de carbono quaternário é um método bastante promissor. Os experimentos utilizaram feixes de elétrons com energia de 6 a $10 \mathrm{MeV}$. O material degradado por radiação foi testado para reutilização na formulação de mistura inicial de borracha de diafragma para a produção de tecido de cobertura emborrachado. Os testes foram realizados em lotes experimentais de devulcanizados a partir de diafragmas usados de $\approx 50 \mathrm{~cm}$ de diâmetro e $\approx 1 \mathrm{~cm}$ de espessura e irradiados com diferentes doses (67, 116, 165 e 128 kGy). Os diafragmas divididos em dois foram colocados em plataformas de produção em linha de transporte e foram transferidos perpendiculares à zona de irradiação, numa velocidade de aproximadamente $10 \mathrm{~mm} / \mathrm{s}$. A qualidade da borracha recuperada foi controlada pelas propriedades apresentadas pelo material 
recuperado, como: o conteúdo das matérias voláteis, cinzas e dureza e propriedades plásticas. As características dos lotes experimentais de borrachas devulcanizadas foram estudadas em função da dose absorvida pelas amostras de diafragma. Estudos em tecidos emborrachados produzidos com borracha butílica recuperada por irradiação mostrou que:

Temperatura de fragilidade: $60^{\circ} \mathrm{C}$; absorção de água: não mais que 1\% resistência ao ozônio (concentração de ozônio é 10-4\%, 168 h, $40^{\circ}$ C) sem rachaduras;

Resistência à radiação ultravioleta (lâmpada de xénon de $80^{\circ} \mathrm{C}$ durante 4000 h), ausência de fissuras.

As áreas de aplicação da borracha butílica recuperada são: artigos técnicos de borracha, coberturas de rolo e tipos de vedação e impermeabilização, entre outros.

Com base nos dados obtidos foi concluido que é possível, a partir da tecnologia de irradiação, recuperar industrialmente resíduos de borracha IIR usando o acelerador de elétrons, com potência de $50 \mathrm{~kW}$ em volumes de até 800 ton./ano.

Wicks $^{93}$ e colaboradores, em 2002, inventaram um processo para tratar e reciclar produtos de borracha, mais particularmente aqueles provenientes de banda de rodagem de pneus. Foi utilizada fonte de micro-ondas, entre $85 \mathrm{~kW}$ e 850 kW de potência, em atmosfera de nitrogênio (para prevenir oxidação excessiva) na frequência de 2,450 MHz. As amostras empregadas possuíam granulometria de 40 mesh, massa entre $30 \mathrm{~g}$ a $300 \mathrm{~g}$ e temperaturas que atingiram até $500^{\circ} \mathrm{C}$. Os melhores resultados foram obtidos para temperaturas no intervalo entre $360^{\circ} \mathrm{C}$ e $380^{\circ} \mathrm{C}$, nos quais as ligações C-S e S-S sofreram modificações. Cerca de $10 \%$ a $50 \%$ de migalhas de borracha reciclada de granulometria entre 200-240 mesh foram incorporadas como carga de reforço em formulções de pneus. Uma das principais limitações na reciclagem de material de pneu usado é a dificuldade de se misturar facilmente, em grandes proporções para formar uma nova mistura de polímero de pneus com propriedades mecânicas e físicas aceitáveis. A borracha reciclada fragmentada foi adicionada 
como carga de reforço na proporção de $12 \%$ e $20 \%$ a novas composições de pneus. Os bons resultados obtidos em ambos os níveis de carga sugerem que cargas entre $25-30 \%$, ou $\geq 50 \%$, podem ser utilizadas em formulações de pneus ou outras aplicações, e ainda obter um produto final com qualidade.

Tang $^{94}$, em 2003 desenvolveu um processo para a recuperação de borracha curada com enxofre, como: borracha natural (NR), Polibutadieno (BR), estireno-butadieno (SBR), polímero de dieno etileno-propileno (EPDM), neoprene (CR), e borracha nitrílica (NBR). O processo da invenção utiliza uma combinação com pequena quantidade de produtos químicos não tóxicos, e uma extrusora com dupla rosca especialmente usada para recuperar sucata de borracha vulcanizada. Os produtos químicos adicionados à borracha vulcanizada, em combinação com o processo de extrusão, contribuem para o cisalhamento adequado para devulcanizar borrachas naturais e sintéticas curadas com enxofre. A borracha recuperada, produzida por esse processo, pode ser revulcanizada como um produto novo, sem a adição de quaisquer aglutinantes e ainda reter a maior parte das propriedades físicas do composto de borracha original; ou ainda, as propriedades da borracha recuperada podem ser melhoradas pela adição de borracha virgem. Em resumo, todo devulcanizado de pneu pode ser moído e combinado com aditivos convencionais e curados durante 10 minutos a $160^{\circ} \mathrm{C}$, para obter um produto revulcanizado com propriedades físicas em torno de 700 Psi de resistência à tração, 180\% de alongamento, e $71 \mathrm{~N} / \mathrm{mm}$ de resistência ao rasgamento. Além disso, a borracha recuperada pode ser misturada com borracha virgem, em proporções variadas, para produção de novos compostos. As propriedades do revulcanizado resultante dependem das características do composto original e da matéria-prima. Por exemplo, sucata de borracha industrial fornece melhores propriedades físicas do que a sucata do pós-consumo.

Wenlay $^{95}$ e colaboradores, em 2004 estudaram a aplicação de ultrassom para a reciclagem de borrachas, com o objetivo de observar mudanças estruturais em vários tipos de borrachas, como: pneu de borracha moída, borracha natural, termopolímero de dieno - etileno-propileno (EPDM), borracha de estireno-butadieno SBR, poli dimetilsiloxano (PDMS, borracha de silicone), borracha de poliuretano (PU) e a borracha de butadieno (BR). Nesse estudo foi 
aplicado tratamento de ultrassom na borracha butílica e na borracha butílica devulcanizada. Para estudar o efeito do ultrassom na estrutura destas borrachas, realizaram um estudo complementar da mobilidade molecular e da rede de ligações cruzadas. Os resultados deste estudo foram comparados com os estudos anteriores de RMN, em outras borrachas devulcanizada. A maioria das evidências apontou para um efeito destrutivo das ligaçãoes físicas e químicas da cadeia polimérica, porém alguns indicadores (fração gel e sol) sugerem que o ultrassom induziu a formação de reticulações.

Jana e Das ${ }^{96}$, em 2005 descreveram que a borracha natural vulcanizada com enxofre foi devulcanizada usando duas concentrações diferentes de dissulfeto dialil. O processo de desvulcanização foi realizado a $110^{\circ} \mathrm{C}$ durante 10 minutos em cilindrio aberto de dois rolos. Foram utilizadas composições curadas com enxofre/aceleradores em diversas proporções para o estudo da clivagem de reticulações monossulfidicas, dissulfídicas e polissulfídicas. Foi demonstrado que as propriedades da borracha natural devulcanizada, melhoraram com o aumento do número de ligações dissulfídicas; e também, as propriedades mecânicas da borracha natural revulcanizada melhoraram em consequência da diminuição do teor de enxofre dos vulcanizados de borracha virgem. Com esse processo foi possível recuperar $70-80 \%$ das propriedades originais da borracha natural. $\mathrm{Na}$ análise espectroscópica ao UV, não foi verificada a ocorrência da oxidação da cadeia principal durante a alta temperatura de moagem.

Wenlai e Isayev $^{97}$, em 2006 utilizaram um método para reciclar borracha butílica empregando como base câmaras de pneus. O processo foi realizado por meio de uma extrusora de tambor de ranhuras com ultrassom. Estes resultados foram correlacionados com propriedades dinâmicas e 0 comportamento de cura da borracha devulcanizada. As propriedades mecânicas da borracha revulcanizada dependem das condições de processamento durante a desvulcanização. Foram obtidos bons resultados para as propriedades mecânicas (tração e alongamento na ruptura) da borracha revulcanizada, e o decréscimo de valores de tração e alongamento na ruptura foram de $86 \%$ e $71 \%$, 
respectivamente, o módulo aumentou em 44\%. Na borracha revulcanizada foram encontradas pequenas partículas de gel, com um tamanho predominante $<4 \mathrm{~mm}$.

Zeid $^{98}$ e colaboradores, em 2008 estudaram a mistura de compósitos de borracha de dieno etileno-propileno (EPDM), polietileno de alta densidade (HDPE) e de pó de borracha de pneus (GTR) que foram misturados em diferentes proporções e submetidos à irradiação gama, em várias doses até 250 kGy. As propriedades físicas, mecânicas e térmicas foram investigadas em função da dose de irradiação e composição da mistura. A irradiação gama conduziu a uma melhoria significativa nas propriedades de todas as composições de mistura. Os resultados indicam que as melhorias nas propriedades são inversamente proporcionais à razão de GTR substituído, melhoria essa atribuída ao desenvolvimento de uma adesão interfacial entre GTR e componentes da mistura. Os resultados foram confirmados pelas análises das superfícies de fratura por microscopia eletrônica de varredura.

Lagarinhos e Tenório ${ }^{85}$ em 2008 estudaram o problema de pneus usados que estão se tornando um problema mundial. O descarte de pneus cresce ano após ano em nível mundial. No Brasil, em 1999, foi aprovada a Resolução no 2/99 do CONAMA (Conselho Nacional do Meio Ambiente) que instituiu a responsabilidade do produtor e do importador pelo ciclo total do produto, ou seja, a coleta, o transporte e a disposição final. Desde 2002, os fabricantes e importadores de pneus devem coletar e dar a destinação final para os pneus usados. Segundo essa lei, os distribuidores, revendedores, reformadores e consumidores finais são corresponsáveis pela coleta dos pneus servíveis e inservíveis, os quais devem colaborar com a coleta. Neste trabalho foram estudadas as tecnologias mais utilizadas no Brasil para a reutilização, reciclagem e valorização energética de pneus que são: recapagem, recauchutagem e remoldagem de pneus; processamento em fornos de cimenteiras; retortagem ou processamento de pneus com a rocha de xisto pira betuminosa; pavimentação com asfalto-borracha; queima de pneus em caldeiras; utilização na construção civil; regeneração de borracha; desvulcanização; obras de contenção de encostas (geotécnica); indústria moveleira; equipamentos agrícolas; mineração; tapetes para reposição da indústria; solados de sapato; cintas de sofás; borrachas de 
rodos; pisos esportivos; equipamentos de playground; tapetes automotivos; borracha de vedação; confecção de tatames; criadouros de peixes e camarões; amortecedores para cancelas em fazendas; leitos de drenagem em aterros, entre outras. Os autores verificaram que as atividades de laminação, trituração e fabricação de artefatos de borracha representaram 50,02\% do total destinado, o processamento em fornos de clínquer representou 35,73\%, a regeneração de borracha sintética representou $13,22 \%$ e a extração e tratamento de minerais $1,03 \%$.

Van Duin ${ }^{99}$ e colaboradores, em 2009 descreveram uma invenção referente a um método para devulcanizar borracha de EPDM curada com enxofre. A desvulcanização ocorre sob aquecimento $\left(+/-275^{\circ} \mathrm{C}\right)$ da borracha na presença de uma agente devulcanizante. O agente devulcanizante é um composto de amina selecionada a partir do grupo consistituido de octilamina, hexadecilamina, dioctilamina, trioctilamina, benzilamina e 4-piperidinopiperidina. Uma desvantagem deste método é que apenas uma parte das reticulações entre enxofre e a cadeia principal dos polímeros de borracha é quebrada. Outra desvantagem deste método é que também ocorre a cisão da cadeia principal. Além disso, outras reações secundárias indesejáveis podem ocorrer, como a formação de compostos cíclicos. A desvulcanização das borrachas curadas com enxofre foi realizada durante 2 horas, em prensa de alta pressão a $267^{\circ} \mathrm{C}$ e pressão de 7,6 MPa, em uma atmosfera de azoto, sem agente devulcanizante. 0 método mostrou-se particularmente adequado para utilização na desvulcanização de borrachas curadas com enxofre e para polímeros com poucas ligações insaturadas carbono-carbono na cadeia principal.

Liang $^{100}$ e colaboradores, em 2010 estudaram a dessulfuração de resíduos de borracha butílica (IIR) em reômetro Haake em elevada temperatura e ação de cisalhamento. Foi investigado o efeito da elevada temperatura na dessulfuração dos residuos de IIR e as propriedades mecânicas desta borracha recuperada, assim como as propriedades de amortecimento dos resíduos da borracha de IIR. Os resulstados mostraram que os residuos de IIR poderiam ser desulfurizados em reómetro Haake. Observou-se que o grau de dessulfurização aumenta com o aumento da temperatura de processamento do reómetro Haake 
entre $200 \mathrm{C}-320^{\circ} \mathrm{C}$. As propriedades dos resíduos de IIR recuperado foram melhores às dos resíduos de IIR puro.

Romualdo ${ }^{101}$ e colaboradores, em 2011 desenvolveram uma tecnologia capaz de reaproveitar resíduos de pneus inserindo-os na composição de concreto para pavimentação de calçadas ecológicas, em substituição ao agregado de pedra moída. Foram feitos quatro traços de concreto, sendo um convencional e três com adição de 5\%, 10\% e 15\% de raspas de pneus para serem avaliadas suas potencialidades. Os ensaios foram realizados aos 3, 7 e 28 dias de idade, em corpos-de-prova cilíndricos de dimensões de $10 \mathrm{~cm}$ x $20 \mathrm{~cm}$ e corpos-deprova prismáticos de dimensões de $5 \mathrm{~cm} \times 5 \mathrm{~cm} \times 20 \mathrm{~cm}$, onde foram avaliadas propriedades como resistência à compressão e tração na flexão, respectivamente. Os resultados indicaram que o traço que melhor satisfaz o uso para pavimentação de calçadas foi o de 5\% de adição de fibras de pneus; porém, apesar de perder em resistência, o concreto borracha ganhou em outras propriedades mecânicas inerentes aos concretos convencionais, principalmente relacionadas à flexibilidade. A utilização deste concreto poderá promover a redução dos pneus inservíveis dispostos inadequadamente no meio ambiente.

Weber $^{102}$ e colaboradores, 2011 desenvolveram e caracterizararam formulações contendo um tipo de resíduo industrial, proveniente da fabricação de perfis automotivos, à base de copolímero de butadieno e estireno (SBR) para possível aplicação industrial. Foram preparadas composições e as mesmas caracterizadas por determinação das propriedades térmicas (calorimetria diferencial de varredura), reológicas (analisador de processamento de borracha), reométricas (reometria de disco oscilatório), mecânicas (resistência à tração e ao rasgamento), químicas (densidade de ligações cruzadas) e morfológicas (microscopia eletrônica de varredura). Os resultados mecânicos indicaram que foi efetivo o processo de revulcanização proposto. Os valores dos parâmetros de tensão na ruptura e resistência ao rasgamento decresceram de 70\% e 50\%, respectivamente, em relação aos valores encontrados para a amostra controle, indicando a possibilidade do uso deste resíduo em artefatos de menor exigência técnica. 
Hirayama e Saron ${ }^{103}$, em 2012 estudaram o processo de moagem da borracha estireno-butadieno (SBR) para posterior desvulcanização e avaliaram os parâmetros dos processos de desvulcanização por micro-ondas. Os resultados mostraram que a redução efetiva do tamanho de partícula de borracha só foi possível com a moagem criogênica e que a desvulcanização realizada em batelada foi mais eficiente quando comparada com o método desenvolvido em modo contínuo. O aperfeiçoamento das técnicas de desvulcanização de elastômeros por micro-ondas mostra perspectivas promissoras para a reciclagem mecânica de elastômeros termofixos.

Tao $^{104}$ e colaboradores, em 2013 investigaram a característica de desempenho e de reprocessamento de borracha moida de pneu recuperado e preparada por desvulcanização, com cisalhamento termo-mecânico. Foi analisada a relação entre o nível de desvulcanização (indicado por fracção de gel e densidade de ligações cruzadas) e a propriedade mecânica. Após desvulcanização foram realizados testes de espectroscopia de infravermelho com transformada de Fourier e estudos de análise elementar, revelaram mudanças na estrutura química dos resíduos de pneus de borracha e ocorrência de muitas reações complexas. A cromatografia de permeação a gel indicou alterações na massa molar e distribuição de peso molecular depois do processo de desvulcanização. A calorimetria diferencial exploratória revelou várias diferenças de estrutura entre a borracha vulcanizada e a borracha reciclada. A microscopia de varredura eletrônica confirmou que a recuperação da plasticidade é distinta entre a borracha devulcanizada e a vulcanizada. A determinação do nível de desvulcanização e as propriedades mecânicas, principalmente à tensão na ruptura só é atingida com o nível ótimo de desvulcanização.

\subsection{Processo de Irradiação}

\subsubsection{Efeitos da radiação de alta energia em polímeros}

Os materiais poliméricos são expostos à radiação de alta energia para modificar ou melhorar suas propriedades para fins industriais. Pesquisas sobre os 
efeitos da radiação ionizante de alta energia em polímeros vem atraindo cada vez mais atenção sob vários pontos de vista:

- Desenvolvimento da radiação como uma ferramenta para pesquisa básica em polímeros;

- Modificações em polímeros por irradiação controlada;

- Desenvolvimento de materiais resistentes à radiação ${ }^{105}$.

Estas áreas são de vital importância para a compreensão da química basica da irradiação envolvendo polímeros específicos.

As principais fontes de irradiação para modificação de polímeros são os raios gama, proveniente de isotópos radiotivos como o Cobalto-60 $\left({ }^{60} \mathrm{Co}\right)$, feixe de elétrons de um acelerador de elétrons e raios $X$ convertidos de um gerador de feixe de elétrons ${ }^{106}$.

Nos processos de interação da energia com a matéria, as radiações ionizantes perdem a sua energia principalmente pela interação com os elétrons orbitais das moléculas localizadas ao longo da sua trajetória, originando estados excitados ou ionizando-as e gerando radicais livres ou íons (FIG. 16).

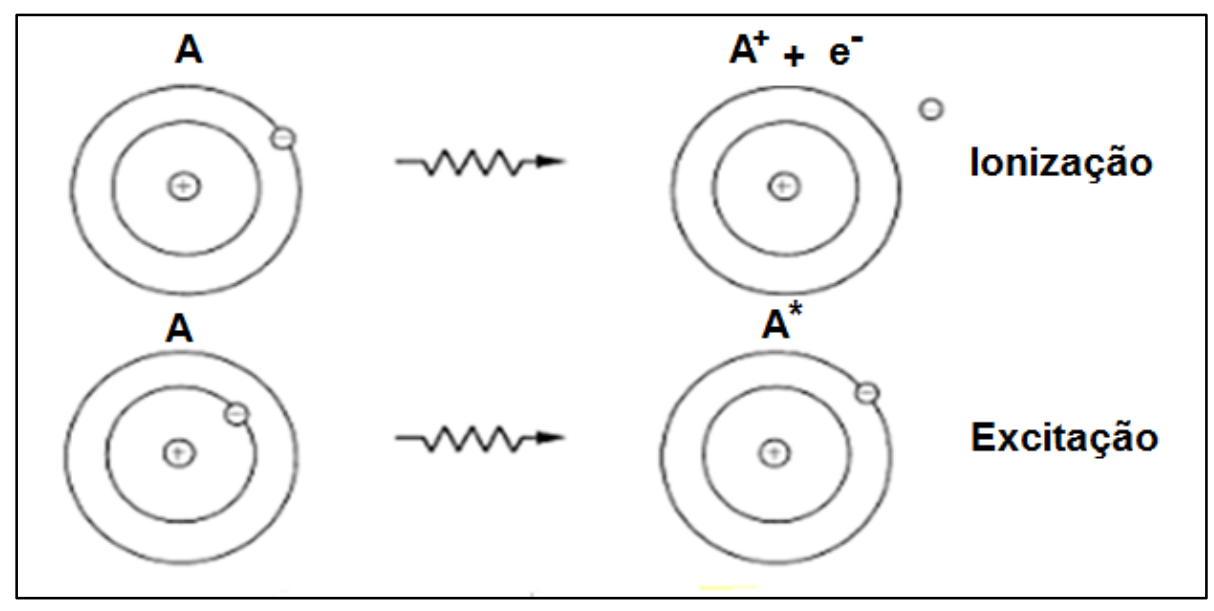

FIGURA 16: Esquema de ionização e excitação ${ }^{107}$. 
Um átomo de uma molécula pode ser ionizado quando a quantidade de energia transferida, proveniente da partícula incidente, é suficiente para arrancar um elétron, ionizando esse átomo ${ }^{108,109}$. Quando a quantidade de energia transferida, proveniente da partícula incidente, é menor que o potencial de ionização da molécula, podem ocorrer excitações eletrônicas, conduzindo um elétron de seu estado de menor energia (estado fundamental) para um estado de maior energia, tornando a molécula instável e reativa quimicamente.

A energia absorvida pela matéria devido à interação com a radiação ionizante pode ser medida diretamente e o rendimento da química das radiações é expresso em termos de um valor $\mathrm{G}$, que representa o número de moléculas modificadas ou formadas por $100 \mathrm{eV}$ de energia absorvida ${ }^{107}$.

Em geral, os eventos induzidos por radiação estão representados na FIG. 17.

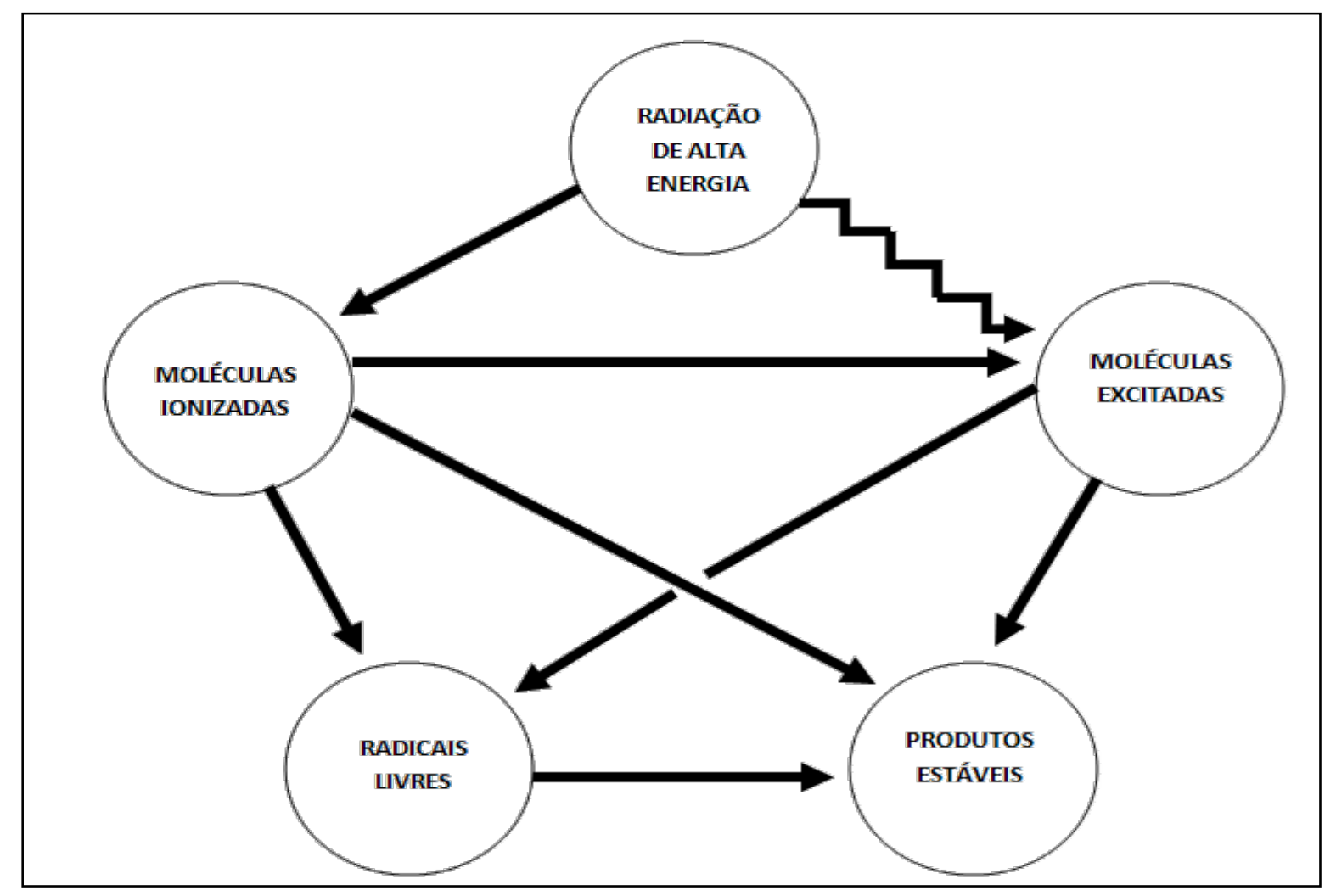

FIGURA 17: Produtos de interação da radiação com átomos ou moléculas ${ }^{110}$. 
As interações primárias de radiação ionizante com polímeros consistem em: ionização, excitação, ocorrendo rapidamente e seguidas da estabilização térmica de elétrons, neutralização de ions e formação de radicais livres. A formação de radicais livres ocorre pela cisão da cadeia polimérica ou pela dissociação da ligação C-H da extremidade da cadeia polimérca. No FIG. 18 são mostrados os processos primários das interações da radiação ionizante com polímeros.

\begin{tabular}{|llll|}
\hline Ionização & $\mathrm{P}$ & $\rightarrow$ & \\
Excitação & $\mathrm{P}$ & $\mathrm{P}^{+}+\mathrm{e}^{-}$ \\
Estabilização térmica do elétron & $\mathrm{e}$ & $\mathrm{P}_{\text {th }}$ \\
Neutralização & $\mathrm{P}^{+}+\mathrm{e}_{\text {th }}{ }^{-}$ & $\longrightarrow \mathrm{P}^{-}$ \\
Formação de radicais livres & $\mathrm{P}^{\bullet}$ & $\longrightarrow \mathrm{R}_{1} \cdot+\mathrm{R}_{2} \cdot$ \\
& & $\longrightarrow \mathrm{R}_{\cdot}+\mathrm{H} \cdot$ \\
\hline
\end{tabular}

FIGURA 18: Processos primários $(\mathrm{P}=\text { polímero, } \mathrm{R}=\text { radical })^{107}$.

Após a formação de radicais livres, as reações secundárias incluem: abstração de hidrogênio, formação de dupla ligação, recombinação (reticulação ou ramificação), cisão de cadeia, oxidação e enxertia (FIG. 19).

\begin{tabular}{|c|c|c|}
\hline Abstração de hidrogênio & $R \cdot+P$ & $\mathrm{RH}+\mathrm{P}$. \\
\hline Adição de dupla ligação & $\mathrm{RCH}=\mathrm{CH}_{2}+\mathrm{H}$. & $\mathrm{RCH}_{2} \mathrm{CH}_{2} \cdot$ \\
\hline Reticulação ou ramificação & $R_{m} \cdot+R_{n} \cdot$ & $R_{m}+R_{n}$ \\
\hline Cisão de cadeia & $\mathrm{R}$. & $\mathrm{R}_{k}=+\mathrm{R}_{i}$ \\
\hline \multirow[t]{2}{*}{ Oxidação } & $\mathrm{R} \cdot+\mathrm{O}_{2}$ & ROO. \\
\hline & ROO. & $-\mathrm{C}=\mathrm{O},-\mathrm{OH},-\mathrm{COOH}$ \\
\hline \multirow[t]{2}{*}{ Enxertia } & $R=+M$ & $\mathrm{RM}$. \\
\hline & $\mathrm{RM} \cdot+n \mathrm{M}$ & $\mathrm{RM}_{\mathrm{n}+1}$. \\
\hline
\end{tabular}

FIGURA 19: Reações secundárias (M= monômero) ${ }^{107}$

Quando a radiação ionizante interage com os materiais poliméricos a energia é absorvida por estes materiais e espécies ativas, analogamente à 
produção de radicais, originam várias reações químicas. Os processos fundamentais que resultam destas reações são:

Reticulação: ocorre quando é formada a ligação entre as cadeias e uma rede de ligações.

Cisão de cadeia: ocorre quando há redução da massa molar do polímero.

Oxidação: ocorre quando as moléculas do polímero reagem com o oxigênio por meio dos radicais de peróxidos (oxidação e cisão de cadeia podem ocorrer simultaneamente).

Enxertia: ocorre quando um novo monômero é polimerizado e enxertado no polímero $^{107}$.

As reticulações são formadas pela recombinação dos radicais polímericos. A FIG. 20 mostra os efeitos da radiação nos polímeros. Conforme a estrutura do polímero, a reticulação e cisão de cadeia são os dois processos que podem ocorrer simultaneamente. Quando o número de pontos de reticulação for duas vezes maior do que os da cisão da cadeia principal, são formados pontos de reticulação ${ }^{107}$. Esse efeito já foi amplamente estudado por vários autores como Charlesby $^{111}$, Lawton e Balwit ${ }^{112}$. Estas descobertas foram confirmadas por estudos posteriores realizados por Chapiro ${ }^{113}$ entre outros. 


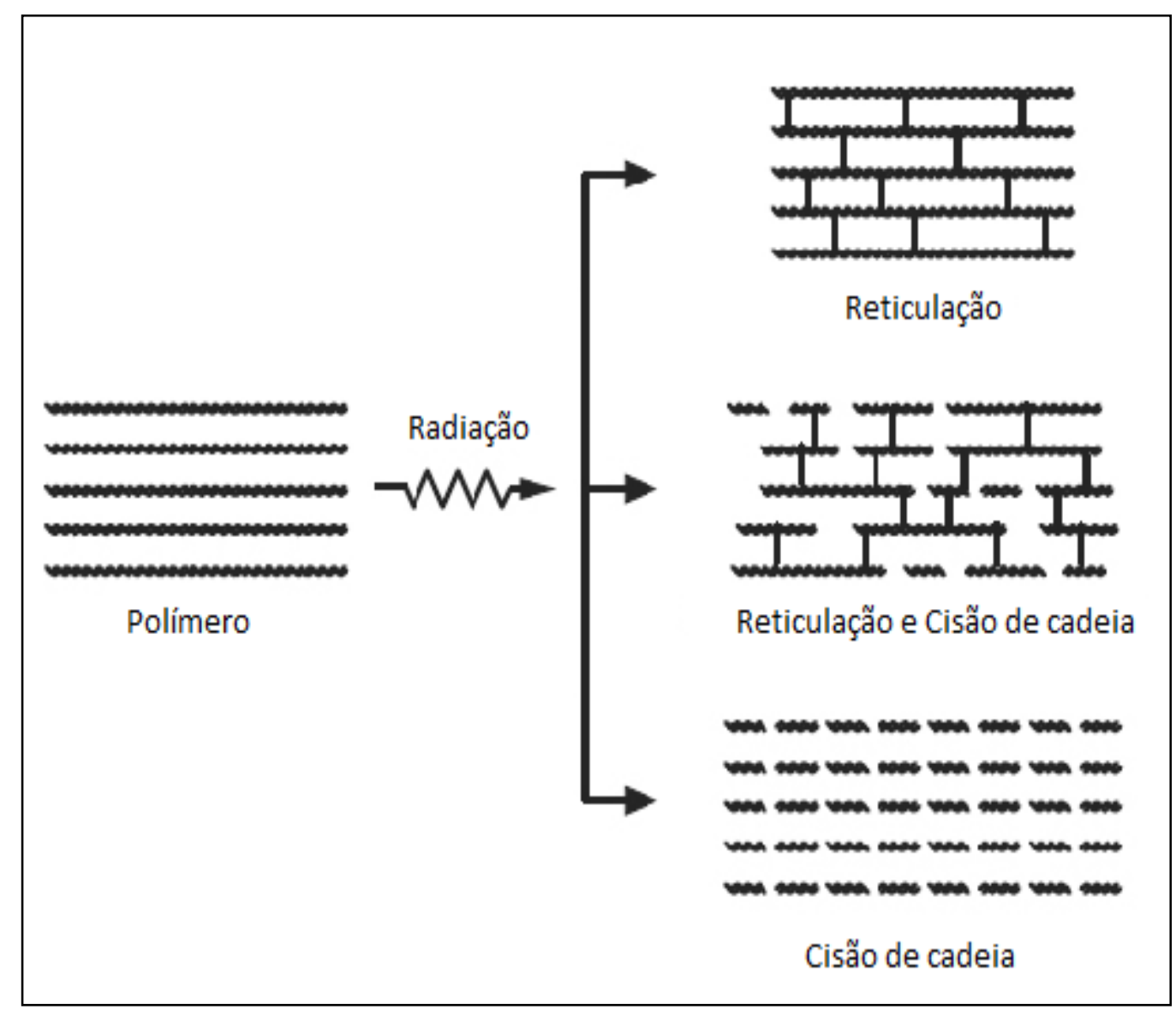

FIGURA 20: Efeito das radiações nos polímeros ${ }^{107}$.

Diferentes polímeros reagem de maneira distinta quando expostos a radiação, especialmente quando ocorre reticulação e cisão de cadeia. Na TAB. 4 são mostrados os valores de $G(X)$ para reticulação e $G(S)$ para cisão de cadeia $^{114,115}$, para alguns tipos de polímeros irradiados na temperatura ambiente e na ausência de oxigênio. Materiais com valores de $G(S): G(X)<1,00$ - a reticulação é favorecida; materiais com valores de $G(S)$ : $G(X)>1,00$ - tendem a degradar e materiais com valores de $G(S)$ e $G(X)$ baixos - são mais resistentes à radiação. As diferentes reações dos polímeros à radiação estão intrinsicamente ligadas à estrutura química do polímero ${ }^{107}$. 
TABELA 4: Valores de $G$ para reticulação e cisão de cadeia de alguns polímeros ${ }^{107}$.

\begin{tabular}{l|l|l|l}
\hline \multicolumn{1}{c|}{ Polímero } & \multicolumn{1}{|c|}{$\begin{array}{c}\text { Reticulação } \\
\mathrm{G}(\mathrm{X})\end{array}$} & \multicolumn{1}{c|}{$\begin{array}{c}\text { Cisão } \\
\mathrm{G}(\mathrm{S})\end{array}$} & \multicolumn{1}{|c}{$\mathrm{G}(\mathrm{S}): \mathrm{G}(\mathrm{X})$} \\
\hline Polietileno de baixa densidade & 1,42 & 0,48 & 0,34 \\
\hline Polietileno de alta densidade & 0,96 & 0,19 & 0,20 \\
\hline Polipropileno isotático & $0,16-0,26$ & $0,29-0,31$ & $1,1-1,5$ \\
\hline Polipropileno atático & $0,4-0,5$ & $0,3-0,6$ & $0,7-0,9$ \\
\hline Polimetilmetacrilato & $<0,50$ & $1,1-1,7$ & $>2$ \\
\hline Politetrafluoroetileno & $0,1-0,3$ & $3,0-5,0$ & 10 \\
\hline Borracha natural & $1,3-3,5$ & $0,1-0,2$ & 0,14 \\
\hline Nylon 6 & $0,35-0,7$ & 0,7 & 1,0 \\
\hline Nylon 6,6 & $0,5-09$ & $07-2,4$ & 1,4 \\
\hline Polivinil acetato & $0,1-0,3$ & 0,06 & 0,2 \\
\hline Fluoreto de polivinilideno & $0,6-1,0$ & $0,3-0,6$ & 0,3 \\
\hline Polimetacrilato & $0,45-0,52$ & 0,08 & 0,15 \\
\hline Poliestireno & $0,019-0,051$ & $0,0094-0,019$ & 0,4 \\
\hline Polibutadieno & 5,3 & 0,53 & 0,10 \\
\hline Poliisobutileno & $0,05-0,5$ & 5,0 & $>10$ \\
\hline Borracha butílica & $<\mathbf{0 , 5}$ & $\mathbf{2 , 9}-\mathbf{3 , 7}$ & $>\mathbf{6}$ \\
\hline & & &
\end{tabular}

A radiação influencia as propriedades mecânicas dos polímeros, em consequência da degradação ou reticulação. A reticulação aumenta as propriedades mecânicas, viscosidade e a estabilidade térmica e diminui o índice de fluidez. A cisão de cadeia, ao contrário, deteriora as propriedades mecânicas e diminui a resistência térmica e a viscosidade do polímero, aumenta o índice de fluide $z^{107,}{ }^{111}$. A presença de oxigênio no processo de irradiação favorece a degradação pela formação de radicais livres peroxídicos (degradação oxidativa) ${ }^{116}$.

Nas borrachas butílicas e halobutílicas expostas a altas energias de radiação, são verificados dois efeitos químicos: reticulação e cisão de cadeia com 
consequente degradação, prevalecendo a cisão de cadeia; e a formação de um gel insolúvel, caso ocorra a predominancia da reticulação ${ }^{107,117}$.

\subsubsection{Raios gama ( $\mathrm{Y})$}

Raios gama são ondas eletromagnéticas, assim como ondas de rádio, luz, raios-X, etc., mas de altíssima frequência; são ondas com comprimento de extraordinariamente curto, com uma enorme capacidade de penetração. A energia deste tipo de radiação é medida em Megaelétron-volts (MeV). Um Mev corresponde a fótons gama de comprimentos de onda inferiores a $10^{-11}$ metros ou frequências superiores a $10^{19} \mathrm{~Hz}$. Os raios gama ionizam a matéria por três processos $^{107}$.

Efeito Fotoelétrico (Ef <1 MeV): Fótons de baixa energia são absorvidos principalmente pelo efeito fotoelétrico. Nesse tipo de interação toda a energia do fóton incidente é transferida para um único elétron atômico, ejetado do átomo com uma energia igual à diferença entre a energia do fóton incidente e a energia de ligação do elétron no átomo ${ }^{107}$.

Efeito Compton ( $\mathrm{Ef}=1$ - $6 \mathrm{MeV}$ ): Um fóton interage com um elétron que pode estar fisicamente ligado a um átomo. Uma parte da energia do fóton incidente é transmitida ao elétron que é acelerado e a outra parte da energia é utilizada na criação de outro fóton, com energia menor que a do fóton incidente. A energia total transferida pela absorção Compton, em qualquer volume, é diretamente proporcional à densidade eletrônica do meio irradiado. O efeito Compton predomina para energias de fótons entre 1 e $6 \mathrm{MeV}$, para materiais de alto número atômico $(Z)$ e para a maioria dos materiais de baixo $Z$ nos demais intervalos de energia ${ }^{107}$.

Produção de pares. (Ef >10 MeV): Envolve a absorção completa de um fóton na vizinhança do núcleo atômico, ou, menos frequentemente, de um fóton elétron com a produção de duas partículas: um elétron e um pósitron. A energia do fóton menos a energia das duas partículas é dividida entre a energia cinética do elétron e do pósitron. O momento é dividido pelos núcleos de recuo. O pósitron é freado de maneira similar ao elétron e a recombinação 
entre o elétron e o pósitron consiste na emissão de raios gama de 0,51 MeV, em direções opostas e é chamada de radiação de aniquilação. Esta interação predomina com fótons com $\mathrm{E}>10 \mathrm{MeV}^{107}$.

O decaimento de alguns isotópos tais como Césio $137\left({ }^{137} \mathrm{Ce}\right)$ também produz raios gama, mas a fonte de emissão de raios gama mais usada para fins industriais é o Cobalto-60 ( $\left.{ }^{60} \mathrm{Co}\right)$. Lascas ou pellets radioativos são feitos a partir de pó sinterizado do isótopo estável de Cobalto 59 (FIG. 21) por soldagem e reação nuclear (período de 18 a 24 meses) através da absorção de nêutrons em um reator nuclear.

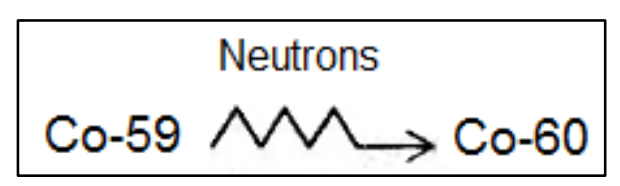

FIGURA 21: Transformação do Cobalto-59 em Cobalto-60

Os raios gama têm sido muito utilizados nos últimos 50 anos para processos de irradiação em polímeros ${ }^{118}$. Segundo a IAEA (International Atomic Energy Agency) ${ }^{119}$ existem ao redor do mundo aproximadamente 160 instalações de processamento de raios gama, sendo que $30 \%$ destas são de processamento de polímeros para melhoria das propriedades destes materiais ${ }^{107}$.

A irradiação via raios gama quando comparada com a irradiação por feixe de eletrons, é mais penetrante, o que lhe confere vantagens para irradiação de produtos com grandes volumes e de formas irregulares. Entretanto a dose absorvida dos raios gama decresce exponencialmente dentro do material com o aumento da profundidade do mesmo ${ }^{120}$.

\subsubsection{Interação das radiações ionizantes com borrachas butílicas e halobutílicas}

Nas borrachas butílicas e halobutílicas, submetidas à radiação de alta energia, podem ocorrer uma variedade de reações químicas na sequência das ionizações iniciais e eventos de excitação. Essas reações alteram a massa molar das borrachas por meio de cisão ou reticulação e afetam as propriedades físicas e mecânicas ${ }^{121}$. O principal efeito da radiação ionizante na borracha butílica é a 
cisão de cadeia acompanhada de redução significativa da massa molar ${ }^{117}$. A transferência de energia da radiação para a borracha butílica não ocorre seletivamente, mas o baixo grau de insaturação dessas borrachas faz com que a cisão ocorra mais rapidamente ${ }^{122}$. Entretanto as borrachas butílicas halogenadas respondem diferentemente aos efeitos da radiação de alta energia. Rápida gelificação ocorre nestes polímeros em doses baixas ${ }^{123}$. As alterações da massa molar média muda também o teor de gel ${ }^{117}$.

A energia de ligação do $\mathrm{C}-\mathrm{Br}(281 \mathrm{~kJ} / \mathrm{mol})^{124}$ é menor do que a energia de ligação do $\mathrm{C}-\mathrm{Cl}(327 \mathrm{~kJ} / \mathrm{mol})^{123}$ que é menor que a energia de ligação $\mathrm{C}-\mathrm{H}$ $(414, \mathrm{~kJ} / \mathrm{mol})^{123}$, portanto a halogenação da borracha butílica para formar a borracha clorobutílica e bromobutílica, melhora a eficiência de reticulação durante a radiação ${ }^{125}$. A adição de átomos de halogênio na borracha butílica promove também um rearranjo molecular durante a dehidrohalogenação da borracha halobutílica formando uma dupla ligação no carbono secundário e terciário para as borrachas bromobutílicas e clorobutílicas respectivamente, o que facilita a formação de ligações cruzadas quando expostas a radiação de alta energia. A bromatação da borracha butílica é ainda mais eficaz para aumentar reticulação por radiação ionizante ${ }^{107}$.

Segundo Zaharescu ${ }^{117}$ e colaboradores, a radiólise da borracha butil halogenada começa com a dehalogenação e dehidrohalogenação com subsequente reticulação promovida pelas estruturas de vinil $\left(\mathrm{CH}_{2}=\mathrm{CH}-\right)$ e vinilideno $\left(\mathrm{CH}_{2}=\mathrm{C}-\right)$. Esta afirmação é baseada na quantidade de polienos que mudam durante a irradiação (FIG. 22). O grande volume do átomo de bromo promove reações mais rápidas e a probabilidade de reagir com qualquer radical vizinho é maior do que para os átomos de cloro ${ }^{117}$. 


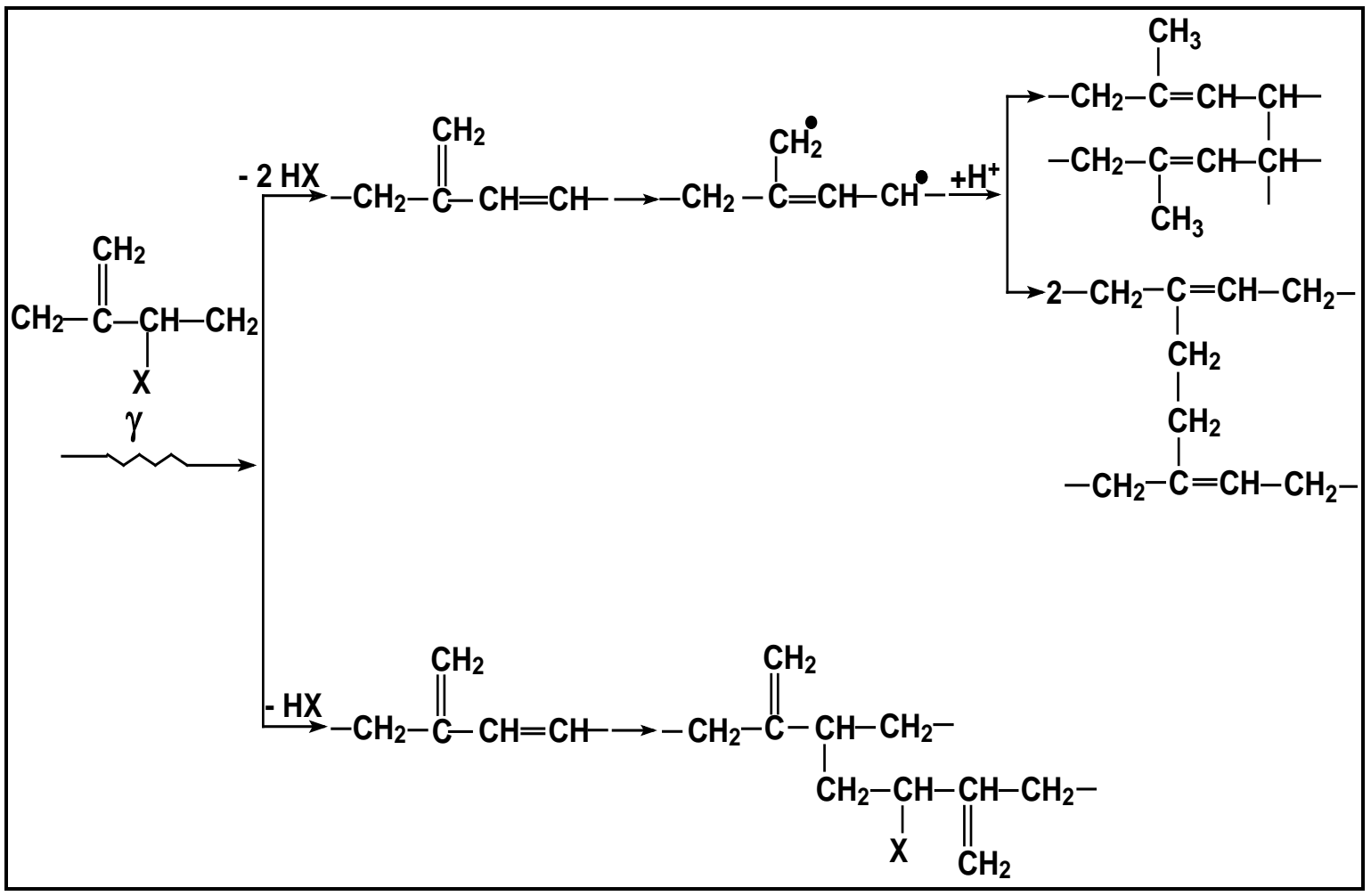

FIGURA 22: Reações intramoleculares envolvidas no processo de reticulação das borrachas halobutílicas ${ }^{117}$.

As principais reações do sistema ocorrem nas unidades de isobutileno (no caso das borrachas butílicas halogenadas-fragmentos isoprênicos). As unidades de isobutileno atingem um estado ativado, que gera moléculas estáveis e radicais livres pela desproporcionalidade; ao mesmo tempo, eles também são direcionados para as estruturas finais de insaturação como vinil e vinilideno (FIG. 23). A quantidade de produtos oxigenados (aldeídos, cetonas, dicetonas, etc.) aumenta em virtude do grande número de radicais peróxidos formados depois das reações de difusão do oxigênio com os radicais livres e a dupla ligação ${ }^{117}$. 


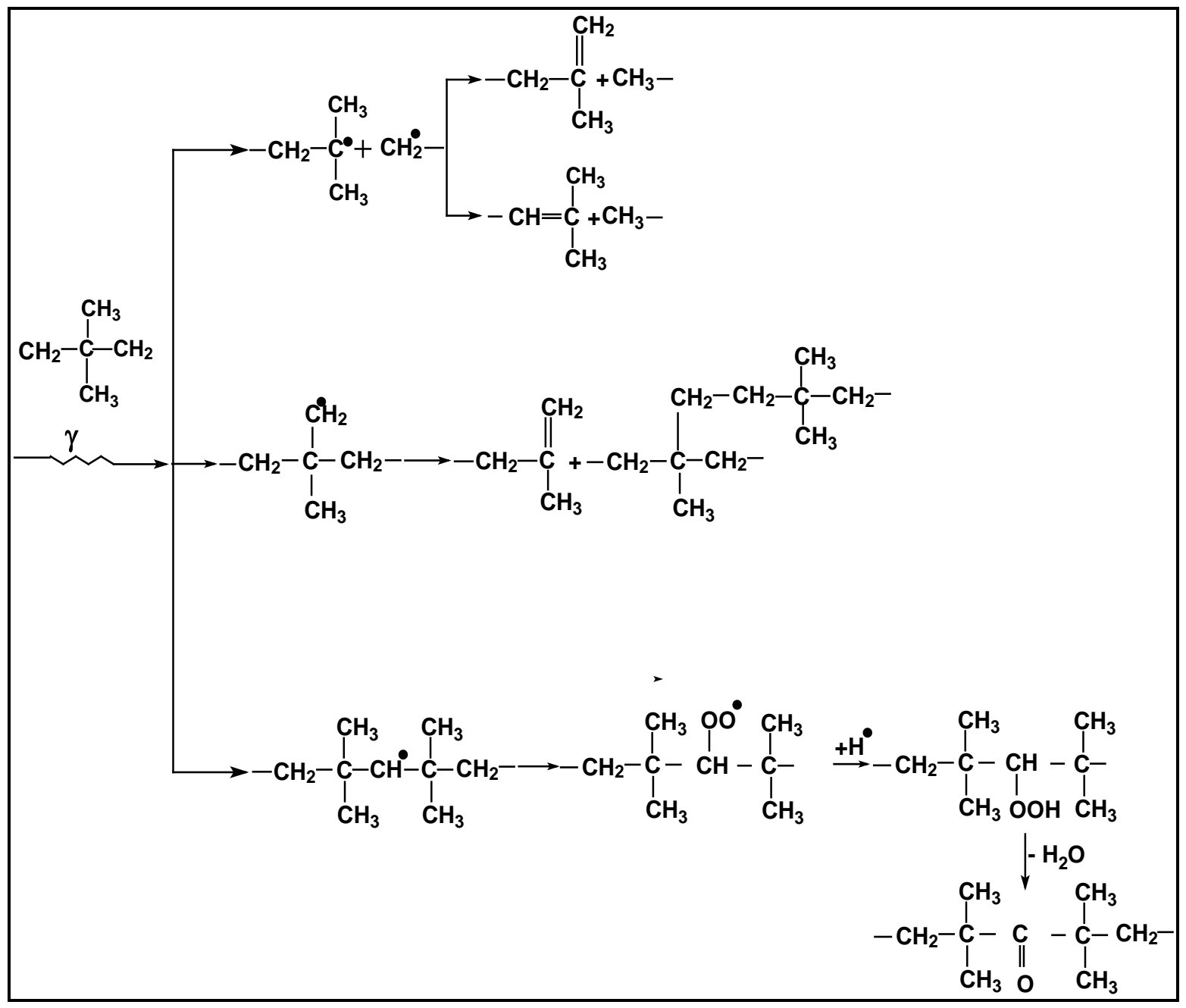

FIGURA 23: Reações da unidade de isobutileno irradiado ${ }^{117}$.

A degradação das borrachas halogenadas seguem as reações mostradas na FIG. 22, porém ocorrem reações adicionais em virtude das unidades de isopreno. A FIG.24 mostra estas reações específicas. Após rearranjos estas estruturas são estabilizadas, ou por reticulação ou por ataque de oxigênio. Denver ${ }^{126}$ sugeriu um mecanismo semelhante de degradação por ataque do átomo de oxigênio. 


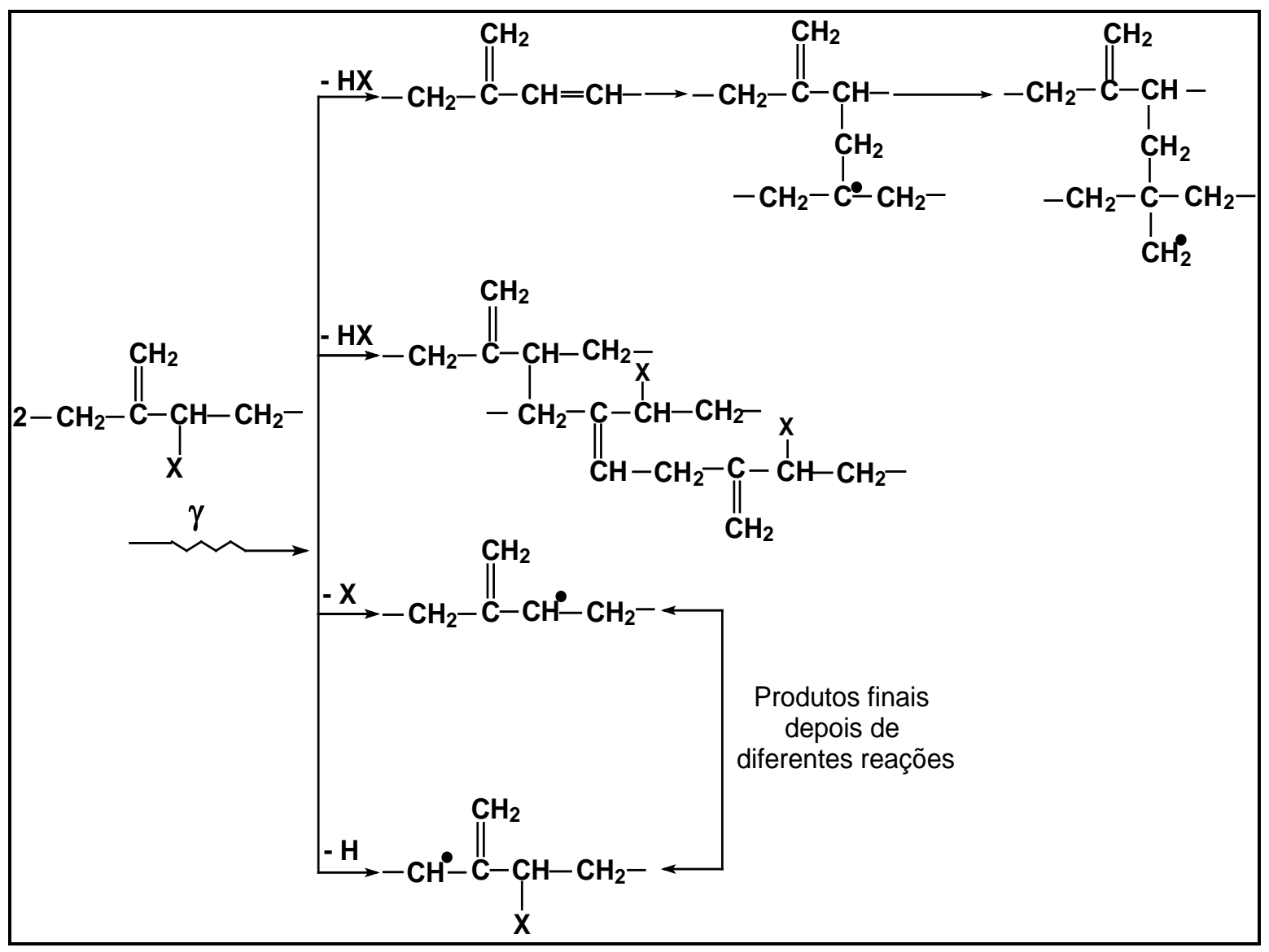

FIGURA 24: Reações da unidade de isopreno irradiado ${ }^{117}$.

Segundo Hill ${ }^{122}$ e colaboradores, o efeito da irradiação em ambas as borrachas halogenadas é predominantemente a reticulação para doses limites de 50 a 100 kGy; acima dessas doses prevalece a cisão de cadeia e a formação de gel aumenta. A cisão de cadeia na borracha clorobutílica é mais intensa do que a cisão de cadeia da borracha bromobutílica, uma vez que os átomos de cloro que são formados durante o rompimento das ligações $\mathrm{C}-\mathrm{Cl}$, abstraem átomos de hidrogênio mais rapidamente do que os átomos de bromo.

Charlesby ${ }^{111}$ em 1953 estudou o processamento de borrachas butílicas por radiação e mostrou tendência à cisão de cadeia. Chapiro ${ }^{108}$ em 1979, também estudou a química de radiação da borracha butílica e observou a sua tendência à cisão da cadeia principal, em virtude da presença de um átomo de carbono terciário. A irradiação de polímeros, utilizando radiação ionizante de fontes industriais (raios gama, elétrons acelerados) promove a criação de intermediários 
muito reativos (íons e estados excitados), que podem seguir caminhos diversos, resultando em: reação de radicais livres e, abstração de hidrogênio, arranjos e/ou formação de novas ligações ${ }^{127}$.

Vários autores concluíram que o principal e praticamente único efeito das radiações ionizantes na borracha butílica é a cisão de cadeia com redução significativa da massa molar afetando as propriedades físicas e mecânicas da borracha $^{116,117,128}$. As borrachas butílicas exibem significante grau de degradação pela ação da radiação ionizante, Ranby e Rabeck ${ }^{129}$, em 1977 estudaram a borracha butílica irradiada com raios gama pela técnica de Eléctron Spin Resonance (ESR) e verificaram que a cisão molecular gera radicais livres alílicos.

Embora os vulcanizados de borrachas butílicas e halobutílicas contenham ingredientes diversos como cargas, negro de fumo, ativadores e agentes vulcanizantes, o comportamento químico à radiação é determinado pela estrutura química destas borrachas; entretanto o grau de degradação vai depender da natureza das cargas e do sistema de vulcanização utilizado ${ }^{130}$.

\subsubsection{Aplicação da radiação ionizante para reciclagem das borrachas butílicas e halobutílicas}

Uma das mais promissoras aplicações de degradação por radiação induzida é a recuperação de sucata de borracha butílica. Essa tecnologia tem sido aplicada comercialmente na China, onde uma planta piloto está em operação para recuperar camaras de pneus após moagem e irradiação ${ }^{131,132,133}$. Pesquisas e desenvolvimento de tecnologias em degradação por radiação têm sido estudados por vários grupos de cientistas, principalmente na Romênia, Russia e Turquia ${ }^{107}$.

Davisdson e Geib ${ }^{134}$, em 1948 foram um dos primeiros a reportarem a possibilidade de recuperar sobras de borrachas butílicas curadas com enxofre por meio de radiação.

Wang $^{135}$ e colaboradores, em 1993 estudaram o efeito da dose de raios y na insaturação e na massa molar da borracha butílica de componentes de 
pneus descartados. Observaram que a média da viscosidade e da massa molar $\left(\mathrm{M}_{\mathrm{v}}\right)$ decresceram rapidamente com o aumento da dose. A insaturação também aumentou com o aumento da dose. A tensão e o alongamento na ruptura assim como o módulo elástico e a dureza diminuíram com o aumento da dose, porém a plasticidade aumentou.

Zaharescu ${ }^{122}$ e colaboradores, em 2001 observaram que a massa molar da borracha butílica decresce com o aumento da dose. O consumo de oxigênio da borracha irradiada aumenta com o acrécimo da dose na medida em que a reação de oxidação forma radicais peróxidicos; isto indica deterioração da estabilidade de oxidação. A radiação $Y$ possibilita o aumento da insaturação da cadeia principal da borracha butílica mais rapidamente do que a radiação com feixe de elétrons.

Telnov ${ }^{136}$ e colaboradores, em 2002 estudaram um método para modificação de borrachas butílicas proveniente de pneus descartados via radiação. Essa tecnologia foi desenvolvida para obter melhores vantagens econômicas e sociais quando comparada com metódos químicos, térmicos e mecânicos. As borachas butílicas foram irradiadas com feixe de eletrons em doses de 6 a $10 \mathrm{MeV}$. Foi observado que a borracha irradiada sofreu uma redução de propriedades mecãnicas e aumento da plasticidade com o aumento da dose. O material degradado por radiação foi testado para reuso em uma formulação de diafragma.

Zhao e $\operatorname{Pan}^{137}$, em 2003 estudaram a degradação por radiação da borracha butilica e verificaram que com o aumento da dose a plasticidade dos pedaços de borracha é aumentada, contribuindo desta forma a elevar a moldabilidade das misturas. As propriedades mecânicas como alongamento e tensão de ruptura são moderamente reduzidas na borracha irradiada. Câmaras de ar contendo em sua formulação $25 \%$ de reciclado são produzidas comercialmente na China. Neste processo o reciclado de borracha butílica é misturado com borracha virgem (borracha butílica ou borracha de etileno e propileno- EPDM) e a mistura é usada para confeccionar pisos e coberturas emborrachadas. O uso de formulações contendo reciclado de borracha butílica irradiada além de trazer 
benefícios ambientais, ajuda a reduzir custos e o tempo de vulcanização, além de produzir vulcanizados com boas propriedades de rasgamento e estabilidade térmica.

Sen ${ }^{138}$ e colaboradores, em 2003 investigaram o efeito da irradiação gama na desvulcanização de borracha comercial de isobutileno-isopreno por meio da degradação induzida por radiação. Neste estudo foi avaliada a Influência da dose de irradiação e da atmosfera na degradação da borracha de butílica por meio das análises de cromatografia e viscosimetria Foi observado que a viscosidade de todas as borrachas butílica diminuiram acentuadamente até a dose de 100 kGy e se estabilizou ao nível da mesma massa molar, independente da dose. O decréscimo da viscosidade foi ligeiramente superior para a amostra irradiada em atmosfera de oxigênio do que em nitrogênio, especialmente para doses baixas. Os rendimentos de reticulação $G(X)$, e de cisão de cadeia $G(S)$ das borrachas butílicas foram calculados usando a média das massas molares da borracha irradiada, obtidas por análises de cromatografia de exclusão de tamanho. Os resultados dos valores de G mostraram que as reações de cisão de cadeia da borracha de isobutileno-isopreno em atmosfera de oxigênio, são mais favoráveis à recuperação do que as amostras irradiadas em atmosfera de nitrogênio; e também que, em doses mais baixa predomina a cisão de cadeia e não a reticulação.

Karaagaç $^{69}$ e colaboradores, em 2007 estudaram a reciclagem da borracha butílica de resíduos interno de pneus e sobras comerciais por meio de radiação $\mathrm{Y}$. A borracha butílica devulcanizada, por métodos convencionais e a devulcanizada por irradiação substituiram até 15 phr na formulação original do composto. As propriedades reológicas, mecânicas e o grau de dispersão do negro de fumo foram analisados para ambas as composições e comparadas com a formulação com $100 \%$ de borarcha virgem. É sabido que as propriedades mecânicas são deterioradas quando se acrescenta borracha fragmentada misturada com borracha virgem em um composto. Portanto, foi concluído que os compostos preparados com borracha butílica irradiada a 120 kGy apresentaram propriedades mecânicas menos deterioradas do que as preparadas somente com 
resíduos de borracha picada. A cura (revulcanização) da formulação contendo borracha irradiada também foi mais rápida.

Vagizova $^{139}$ e colaboradores, em 2007 estudaram e compararam a recuperação de borrachas butílicas utilizando três métodos, que são os mais utilizados para recuperação destes resíduos: água neutra, termomecânica, e radiação. Foi realizado o estudo das propriedades mecânicas da borracha butílica recuperada pelos três diferentes métodos de recuperação. Foi verificado que o método de recuperação via irradiação conferiu melhor qualidade ao produto cujos vulcanizados apresentaram uma melhor estabilidade térmica para as propriedades de tensão e deformação. Foi também mostrado que a borracha butílica recuperada por radiação pode ser usada para a produção de betumes para telhados, vedantes, adesivos e aditivos. $\mathrm{O}$ material com melhores características adesivas é obtido com dose de radiação de 200 kGy.

Landini $^{140}$ e colaboradores, em 2007 estudaram a desvulcanização e recuperação da borracha bromobutílica (BIIR) usando o processo de micro-ondas. Neste trabalho, foi utilizado um sistema de geração de calor com frequência de micro-ondas de 2,45 GHz. As amostras de BIIR (cerca de 0,250 kg), de restos de: borrachas de produção de tampas farmacêuticas foram irradiadas em potências de 1000 W, 2000 W e 3000 W, com diversos tempos de aquecimento: 540s (9 min) até 1500s (25 min). As amostras não irradiadas e irradiadas foram caracterizadas por análise reométrica, dureza e teste de cinzas. As melhores condições de operação foram obtidas a 780s e 2000 W. Os resultados mostraram que o processo de micro-ondas causou efeito expressivo na recuperação BIIR. Algumas amostras apresentaram a tendência de uma nova vulcanização. Os autores concluiram que existe grande expectativa para reutilização e reciclagem do BIIR pelo processo de micro-ondas, sem a utilização de qualquer agente químico.

Khakimullin ${ }^{141}$ e colaboradores, em 2008 estudaram a possibilidade de substituir a borracha butílica virgem por borracha butílica degradada via irradiação induzida para a produção de impermeabilizante e materiais de cobertura utilizados na indústria de construção. Foi investigada a eficiência de utilização de 
compostos nitrosos, tais como éter p-dinitrobenzeno e quinol como agentes de vulcanização. A radiação foi aplicada a tubos de diafragmas que possuem elevadas propriedades mecânicas. O produto irradiadao com 20 Mrad se mostrou satisfatório para uso como adesivo. Conforme conhecido, à massa molar da borracha butílica diminui depois da irradiação. A adição de 30 partes do produto irradiado em uma massa de 100 partes de borracha virgem melhorou a aderência ao concreto, aço, polietileno, etc., outras propriedades permaneceram inalteradas.

Smith ${ }^{142}$ e colaboradores, em 2013 estudaram o efeito da radiação gama usando uma fonte de ${ }^{60} \mathrm{Co}$ em atmosfera inerte a $25^{\circ} \mathrm{C}$ e $70^{\circ} \mathrm{C}$ em um elastômero de borracha butílica, carregado com negro de fumo. Durante o envelhecimento foi observado um aumento da resistência à tração do material. A melhora das propriedades mecânicas ocorreu devido a uma modificação da estrutura da rede da borracha; esta hipótese foi confirmada pelo teste de inchamento realizado antes e após envelhecimento, em várias doses de irradiação e foram associadas com a densidade de reticulação obtida pela equação de Flory-Rehner. Sob irradiação ocorreram reações de reticulação e cisão de cadeia; a contribuição de ambos os processos foi dada pela equação de Charlesby-Pinner. O elevado conteúdo de negro de fumo na formulação de borracha butílica também ajudou no processo de degradação. Foram também apresentadas as correlações entre as propriedades mecânicas e a densidade de reticulação. A modificação das propriedades mecânicas da borracha enfatiza que o mecanismo de degradação é altamente influenciado pela temperatura, especialmente para doses elevadas de irradiação. A $25^{\circ} \mathrm{C}$, o processo de reticulação predomina sobre a cisão de cadeia; e os dois fenômenos estão em competição, à temperatura de envelhecimento de $70^{\circ} \mathrm{C}$. O estudo revela uma mudança completa das propriedades desta borracha durante o envelhecimento.

Os avanços nas tecnologias de reciclagem podem ser úteis para os esforços futuros na área da reciclagem por meio de radiação. Como apontado anteriormente, a vasta gama de pesquisa foi realizada em borrachas (matériaprima) e sobre as composições de pneus usados. 
Trabalhos foram publicados com sucesso sobre desvulcanização de borracha usando reagentes químicos, microondas ou ultra-som .Embora a pesquisa sobre a aplicação da radiação para o problema da reciclagem de polímero ainda não é generalizado, uma série de pesquisas que envolve o tratamento de sucata de polímero por radiação estão sendo desenvolvidas .

O uso de raios gama para reciclagem de borrachas, é um processo bastante limpo, sem resíduos de refino. Algumas publicações descrevem experiências em que são misturadas borracha virgem com borracha recuperada por irradiação, e são relatados que para alguns casos as características das borrachas são melhoradas, incluindo a diminuição no tempo de vulcanização.

As perspectivas futuras para o uso de radiação em reciclagem de borrachas, oferece possibilidades únicas, devido à sua capacidade para promover reticulação, cisão de cadeia ou cisão e reticulação nas borrachas butílica e butílica halogenada. A recuperação de borracha butílica e halobutílca pelo processamento de raios gama seguido de cisalhamento pode representar um papel significativo no futuro para a recuperação destes resíduos. Embora, alguns aspectos tecnológicos devam ser desenvolvidos de modo a tornar mais atraente a implementação desta tecnologia em escala industrial.

A tecnologia de recuperação de borrachas butílica e halobutílica, por irradiação seguida de cisalhamento mecânico, mostrou-se promissora no cenário da reciclagem, pois a metodologia empregada para a recuperação das borrachas difere das aplicações já conhecidas. Com base nos resultados experimentais, este processo de recuperação/reciclagem, mostrou-se eficaz para recuperar borrachas butílica e halobutílica. Principalmente para a borracha clorobutílica, pois não foram encontrados trabalhos a respeito da recuperação deste tipo de borracha. 


\section{MATERIAIS E MÉTODOS}

\subsection{Matérias-primas}

Os polímeros estudados no processo de reciclagem e/ou reaproveitamento das borrachas butílicas e halobutílicas foram:

- Butil 268: viscosidade Mooney $\left(\mathrm{ML} 1=8,125^{\circ}\right)=51 \mathrm{e}$ insaturação de 1,70\% mol.

- Bromobutil 2222: viscosidade Mooney $\left(\mathrm{ML} 1=8,125^{\circ}\right)=32 \mathrm{e}$ bromo $=1,03 \% \mathrm{~mol}$.

- $\quad$ Clorobutil HT 1066: viscosidade Mooney $\left(\mathrm{ML} 1=8,125^{\circ}\right)=32 \mathrm{e}$ cloro $=1,26 \% \mathrm{~mol}$.

Todas as borrachas foram fabricadas pela EXXON MOBIL CHEMICAL e vulcanizadas por três diferentes sistemas de cura:

- Cura com resina;

- Cura com enxofre e aceleradores;

- Cura com doadores de enxofre.

$\mathrm{Na}$ cura dos compostos de borracha butílica e halobutílica com resina foi utilizada a resina de octilformol formaldeído (nome comercial, resina SP 1045) da Schenectady Chemical's. Os outros aditivos utililizados foram: óxido de zinco, enxofre, estearina e plastificante (Basile Química); TMTD, MBTS, ZMDC, ZBDC e ZBEC (Enro Industrial Ltda); negro de fumo N-330 (Cabot Brasil, e Columbian Chemicals Brasil). Todos os materiais são grau comercial e foram utilizados como recebidos. 


\subsection{Preparação das amostras}

Foram preparadas amostras de borracha butílica com os três diferentes sistemas de cura (TAB. 5), o mesmo procedimento foi efetuado para a borracha bromobutílica (TAB.6) e borracha clorobutílica (TAB.7) e, teve como referência, formulações usadas na indústria de pneus e autopeças. As formulações estão em phr, ou em partes em peso de material por cem partes de borracha.

TABELA 5: Formulação de borracha butílica

\begin{tabular}{c|c|c|c}
\hline Ingredientes & $\begin{array}{c}\text { Amostra 1 } \\
(\text { phr })\end{array}$ & $\begin{array}{c}\text { Amostra 2 } \\
(\text { phr })\end{array}$ & $\begin{array}{c}\text { Amostra 3 } \\
\text { (phr) }\end{array}$ \\
\hline Borracha butílica & 100 & 100 & 100 \\
\hline $\begin{array}{c}\text { Borracha de } \\
\text { cloropreno }\end{array}$ & 5 & - & - \\
\hline Óxido de Zinco & 5 & 5 & 5 \\
\hline Estearina & 0,5 & 1 & 1,5 \\
\hline Plastificante & 5 & 25 & 20 \\
\hline Negro de Fumo & 60 & 70 & 50 \\
\hline Resina Fenólica & 10 & - & - \\
\hline Enxofre & - & 2 & 1,75 \\
\hline TMTD & - & 1 & 1,0 \\
\hline MBTS & - & 0,5 & \\
\hline
\end{tabular}


TABELA 6: Formulação de borracha bromobutílica

\begin{tabular}{c|c|c|c}
\hline Ingredientes & Amostra 4 $\quad$ (phr) & Amostra 5 (phr) & Amostra 6 (phr) \\
\hline Borracha bromo butílica & 100 & 100 & 100 \\
\hline Óxido de Zinco & 5 & 3 & 5 \\
\hline Estearina & 0,5 & 1 & 1 \\
\hline Plastificante & 5 & 25 & 25 \\
\hline Negro de Fumo & 60 & 70 & 70 \\
\hline Resina Fenólica & 10 & - & - \\
\hline Enxofre & - & 0,5 & - \\
\hline TMTD & - & - & 1,0 \\
\hline MBTS & - & 0,5 & 2,0 \\
\hline ZMDC & - & 0,1 & - \\
\hline
\end{tabular}

TABELA 7: Formulação de borracha clorobutílica

\begin{tabular}{c|c|c|c}
\hline Ingredientes & Amostra 7 (phr) & Amostra 8 (phr) & Amostra 9 (phr) \\
\hline Borracha cloro butílica & 100 & 100 & 100 \\
\hline Óxido de Zinco & 5 & 5 & 5 \\
\hline Estearina & 0,5 & 1 & 1 \\
\hline Óxido de magnésio & - & 0,5 & 0,3 \\
\hline Plastificante & 5 & 28 & 15 \\
\hline Negro de Fumo & 60 & 75 & 50 \\
\hline Resina Fenólica & 10 & - & - \\
\hline Enxofre & - & 0,5 & - \\
\hline ZBDC & - & - & 2 \\
\hline ZBEC & - & 2 & - \\
\hline
\end{tabular}


As amostras foram preparadas em um misturador de cilindro aberto (Copê), com dois rolos (FIG. 25), capacidade para $40 \mathrm{~kg}$, segundo norma ASTM $\mathrm{D}-3182^{143}$, em temperatura entre $50^{\circ} \mathrm{C}$ e $60^{\circ} \mathrm{C}$.

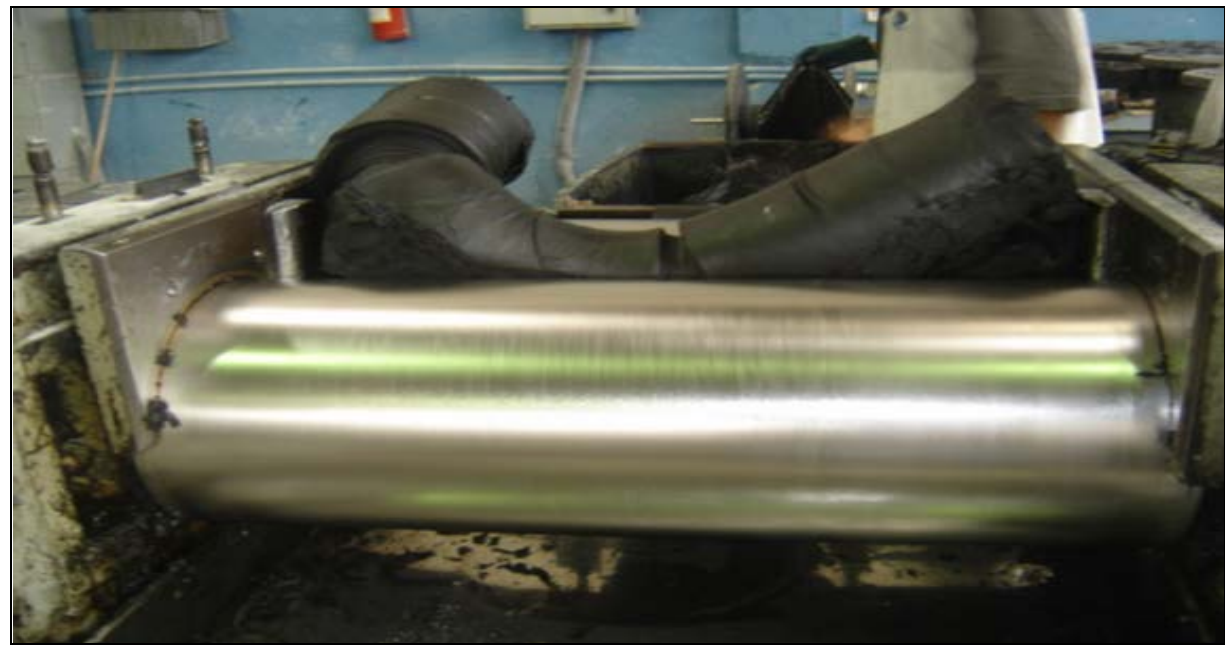

FIGURA 25: Misturador de cilindro aberto de dois rolos (Copê).

Depois da preparação das misturas (cujas composições encontram-se nas TAB. 5, 6 e 7), foram realizados testes de Reômetro Monsanto MDR 2000, para predizer os parâmetros de processamento dos compostos e medir suas características de cura e o tempo $\left(T_{90}\right)$ de prensagem. Em seguida as misturas foram vulcanizadas em prensa hidráulica da marca HIDRAUL-MAQ, pressão de 5 MPa e preparadas conforme norma ASTM D-3182 ${ }^{143}$.

Após a confecção dos corpos de prova, de dimensões 12 x 15 cm e 2 $\mathrm{mm}$ de espessura, os mesmos foram divididos em duas partes, sendo que uma delas foi cortada em pedaços de aproximadamente $1 \mathrm{~cm} \times 1 \mathrm{~cm}$, a outra metade foi mantida em manta, conforme apresentado na FIG. 26 e embalados em sacos plásticos e enviados para irradiar na CBE/EMBRARAD (Companhia Brasileira de Esterelização). 


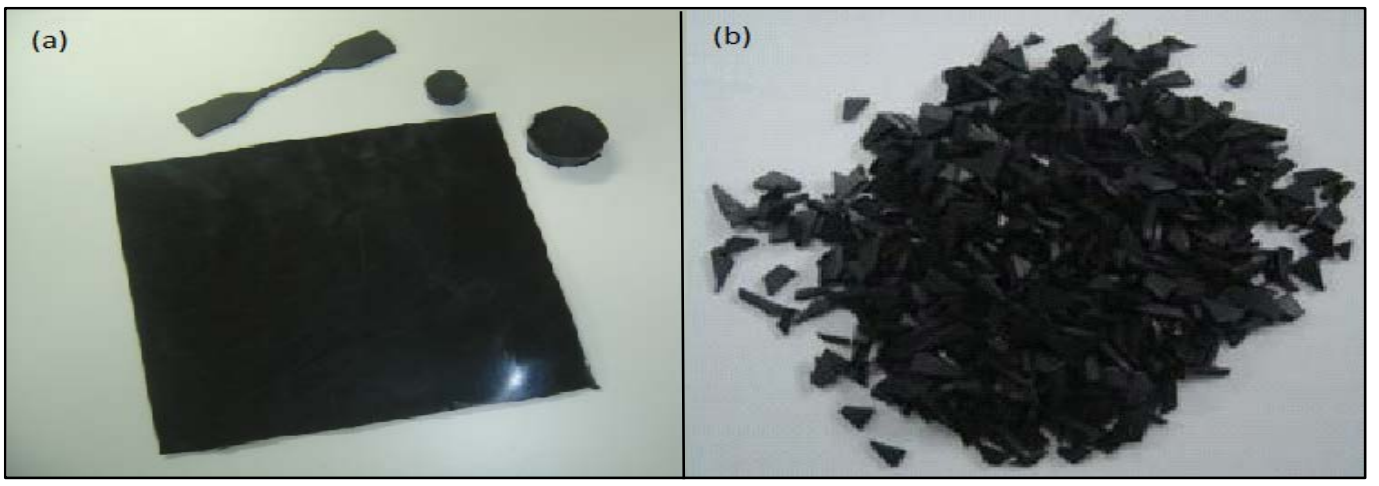

FIGURA 26: Modelo de corpo de prova em manta (a) e picotados (b).

A FIG. 27 apresenta um fluxograma com o resumo dos processos e análises realizadas antes da irradiação.

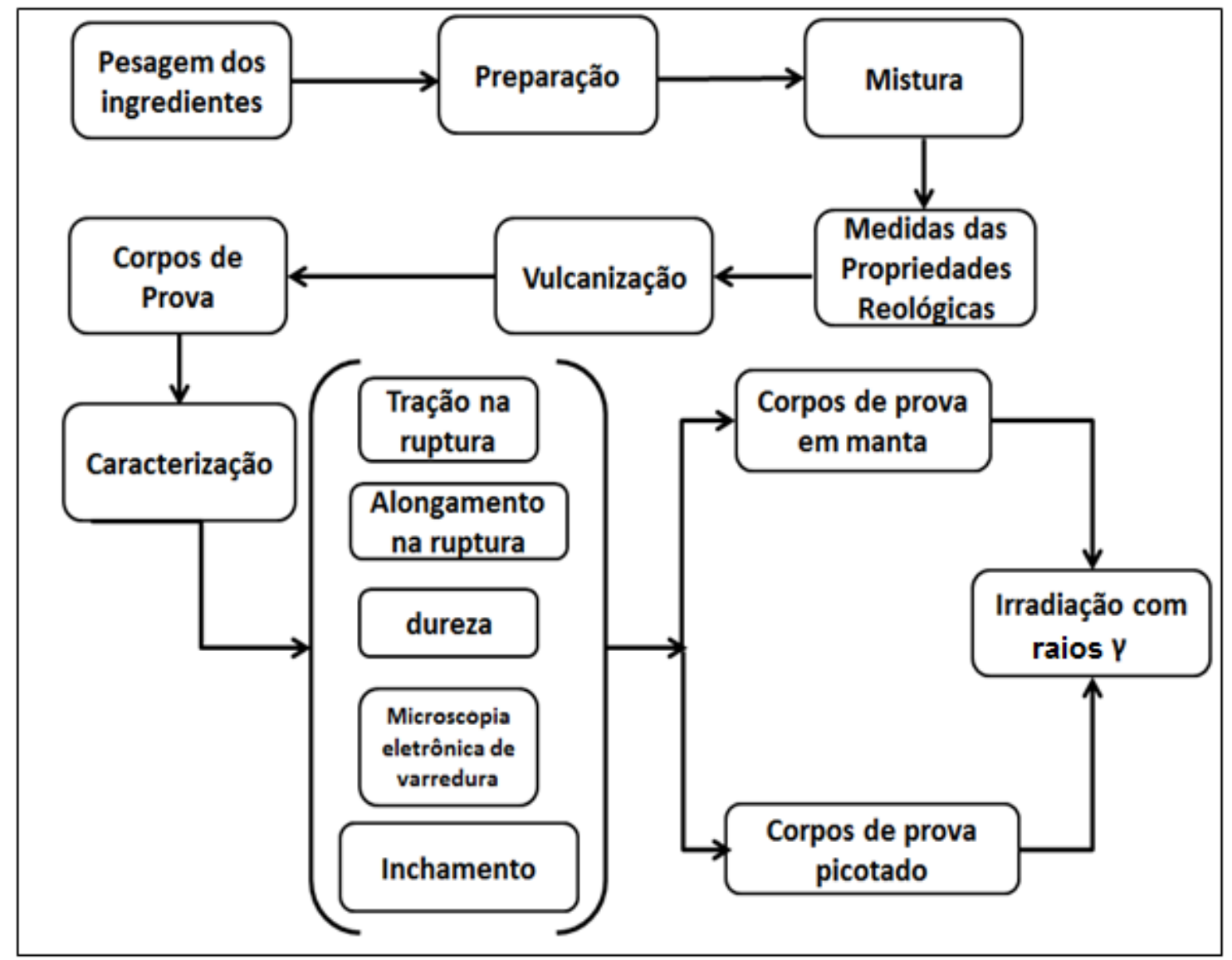

FIGURA 27: Fluxograma dos processos e das caracterizações das amostras antes da irradiação. 


\subsection{Irradiação das amostras}

As amostras foram irradiadas na CBE/EMBRARAD e corpos de prova, em mantas e picotados, foram submetidos à radiação gama em atmosfera de ar, nas doses de 5 kGy, 15 kGy, 25 kGy, 50 kGy, 100 kGy, 150 kGy e 200 kGy, em irradiador gama, a base de cobalto-60, da Nordion modelo JS 7500 com taxa de dose aproximada de $5 \mathrm{kGy} \mathrm{h}^{-1}$, em 2011.

Depois de irradiadas, as amostras picotadas foram reprocessadas em cilindro de dois rolos para homogeneização da mistura e confecção de novos corpos de prova. As amostras irradiadas em mantas foram caracterizadas sem reprocessamento. De acordo com os resultados dessa etapa foram selecionadas as amostras, utilizadas em substituição a partes da borracha virgem na confecção de novos compostos. A FIG. 28 apresenta um fluxograma com os processos e análises realizadas nas amostras após a irradiação.

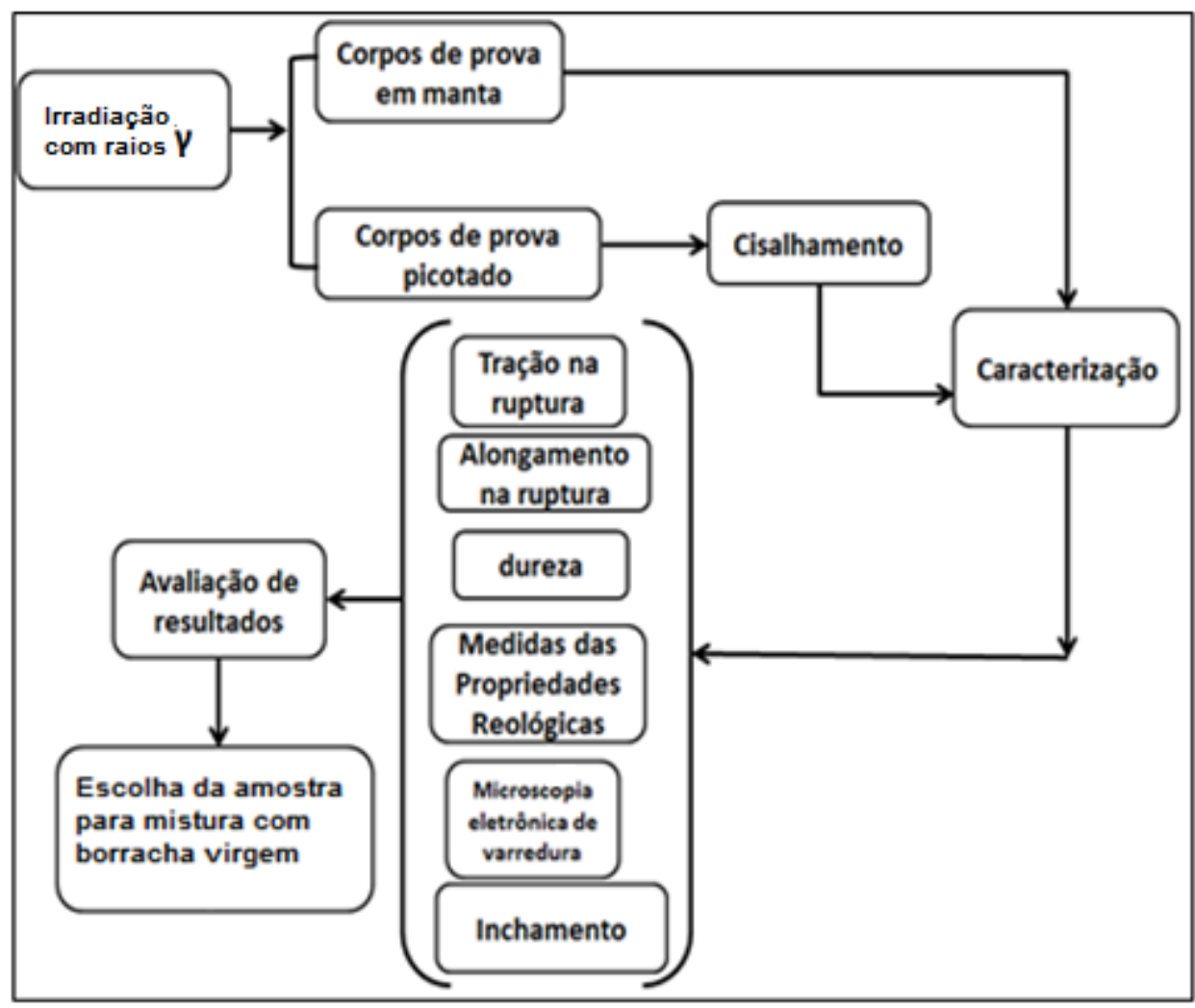

FIGURA 28: Fluxograma dos processos e das caracterizações das amostras depois da irradiação. 


\subsection{Processamento em cilindro (cisalhamento)}

Nos processos mecânicos de regeneração, a borracha é degradada, por ação mecânica (cilindros, moinhos e extrusoras), provocando o seu alongamento e, consequentemente, a ruptura das macromoléculas ${ }^{144,145}$, diminuindo sua massa molar. No caso das borrachas vulcanizadas e irradiadas, o processo de degradação mecânica ocorre de modo análogo.

A homogeneização dos compostos irradiados picotados foi realizada em um misturador aberto de dois rolos da marca Copê. As mantas de borracha obtidas (FIG. 29) foram posteriormente caracterizadas.

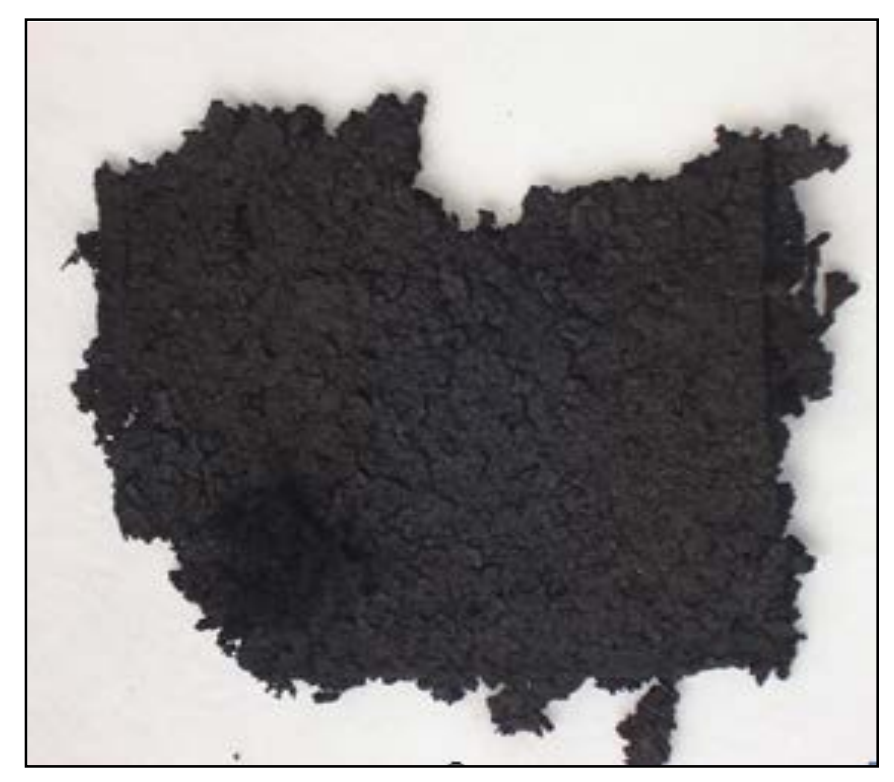

FIGURA 29: Amostra após a irradiação e cisalhamento.

\subsection{Caracterizações dos compostos}

Os ensaios realizados nas composições foram em triplicata, e os resultados obtidos são as médias aritméticas dos valores parciais. As análises foram feitas segundo as normas ASTM. Os corpos-de-prova foram preparados, em prensa hidraulica e cortados de acordo com os métodos específicos de cada ensaio. Para controle do processo, foram avaliadas as propriedades a seguir. 


\subsubsection{Dureza}

Os valores de dureza foram determinados segundo a norma ASTM D$2240^{146}$. O aparelho empregado foi um durômetro shore A da marca Instrutemp, modelo digital portátil Dp-100. Esta propriedade está relacionada com a densidade de ligações cruzadas.

\subsubsection{Resistência à tensão e alongamento na ruptura}

Os valores de resistência à tração e alongamento na ruptura foram determinados seguindo a norma ASTM D-412 ${ }^{147}$, utilizando corpo de prova modelo C, em máquina universal de ensaio (EMIC), modelo DL $300 \mathrm{com}$ capacidade máxima de $300 \mathrm{kN}$ e velocidade de separação entre as garras de 500 $\mathrm{mm} / \mathrm{min}$ em temperatura ambiente (FIG. 30).

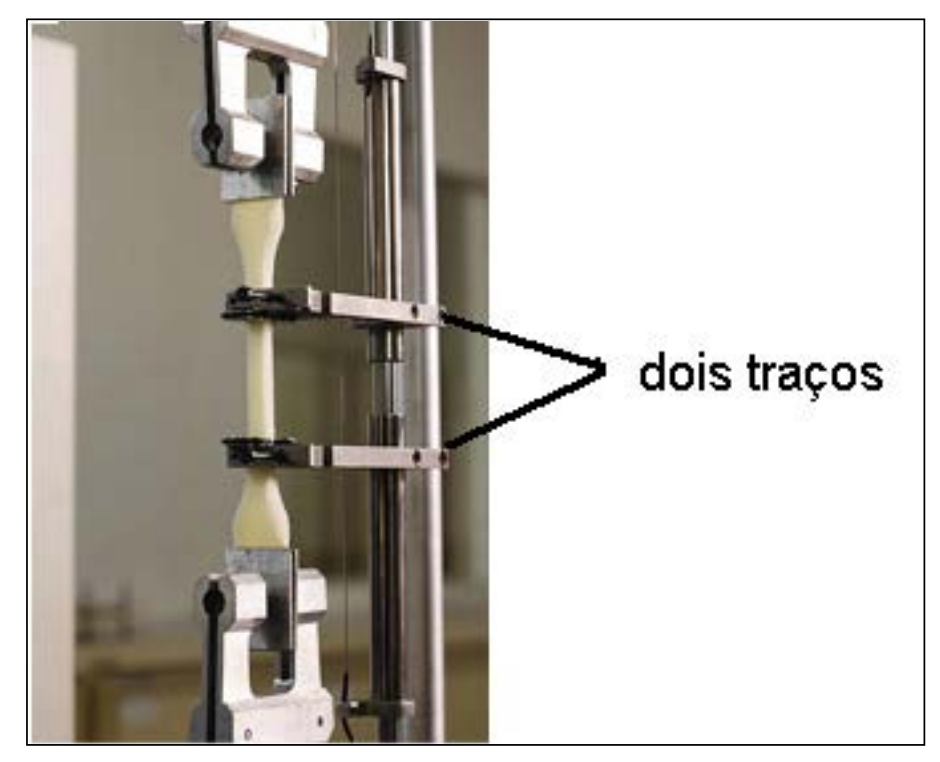

FIGURA 30: Foto do corpo-de-prova do ensaio de tensão e alongamento na ruptura, marcado com dois traços.

\subsubsection{Determinação do índice de inchamento de borracha}

Os corpos de prova nas dimensões aproximadas $1,5 \mathrm{~cm} \times 1,5 \mathrm{~cm}$ foram previamente pesados e imersos em tolueno até estabilização do peso (mais ou menos cinco dias). Ao término do ensaio os corpos de prova foram pesados e 
depois secos à temperatura ambiente por 24 horas. Para estas análises, foi utilizada a norma ASTM D-3616 ${ }^{148}$.

O grau de inchamento foi calculado de acordo com a EQ. 2:

$$
\mathrm{Q}=\left(\mathrm{M}-\mathrm{M}_{0}\right) / \mathrm{M}_{\mathrm{O}} \times 100
$$

Onde:

$M_{0}$ é a massa inicial da amostra (g) e

M é a massa final da amostra $(g)^{149}$.

Para o cálculo da variação de massa seca $(P)$ foi utilizada a relação apresentada na EQ 3:

$$
\mathrm{P} \%=\frac{\text { Mo }- \text { Ms }}{\text { Mo }} \times 100
$$

Onde:

Mo é o peso da amostra (g) antes do inchamento e

Ms é o peso da amostra seca (g) após o ensaio de inchamento.

\subsubsection{Características reométricas}

A análise reométrica dos compostos elastoméricos foi realizada submetendo uma amostra não vulcanizada do composto a um ensaio no Reômetro Monsanto MDR 2000 (FIG. 31), o qual fornece a curva reométrica sob a qual são calculados os dados de interesse. As análises foram realizadas de acordo com a norma ASTM D-2084 ${ }^{150}$. 


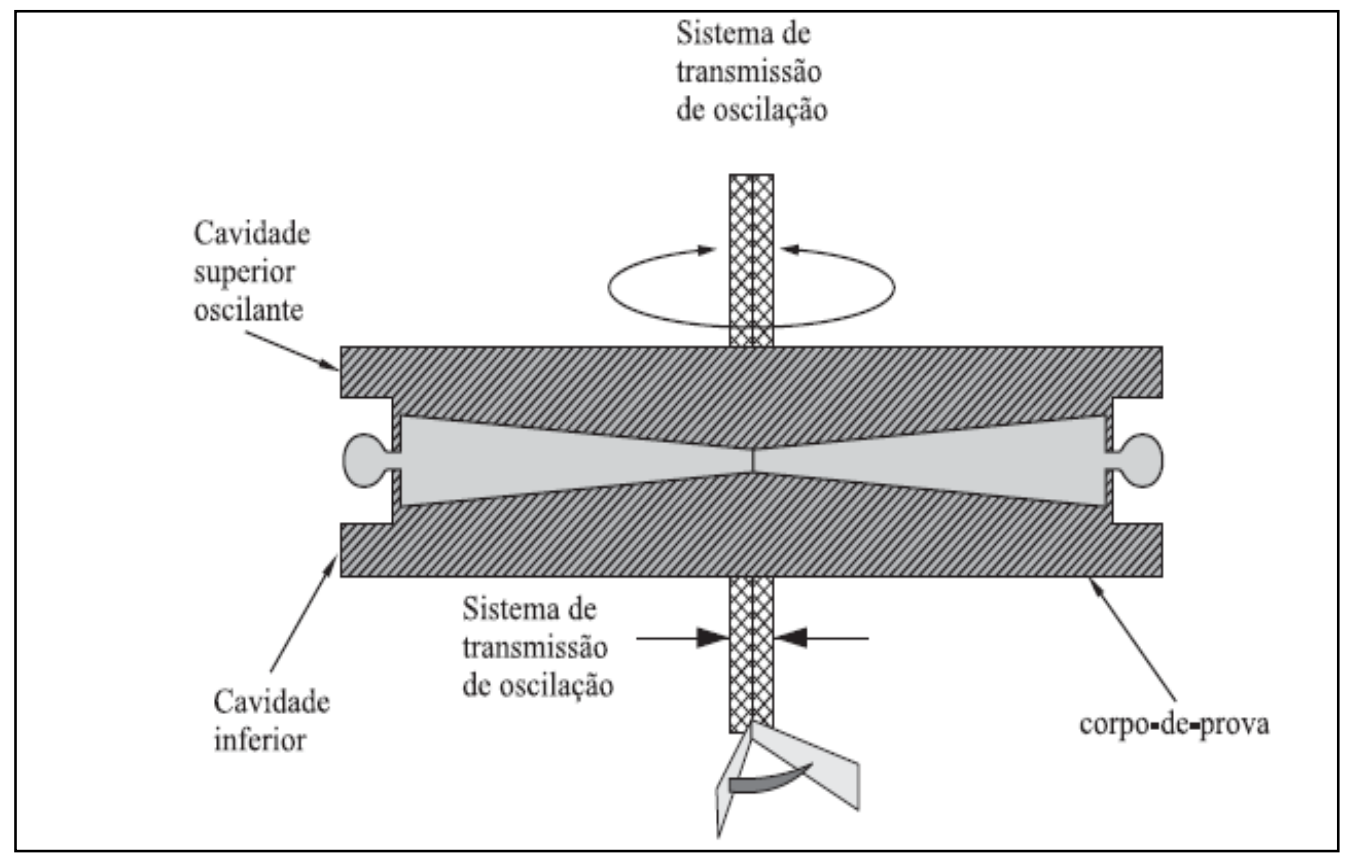

FIGURA 31: Esquema da cavidade de teste dos reômetros tipo MDR ${ }^{58}$.

O método especifica frequência de trabalho de $1,67 \mathrm{~Hz}$ e amplitude de oscilação de $+/-3^{\circ}$. A partir da curva reométrica, o ensaio fornece os seguintes dados:

$\mathrm{ML}=$ Torque mínimo atingido $(\mathrm{dN} . \mathrm{m})$, que reflete razoavelmente a viscosidade de uma composição à temperatura de vulcanização considerada.

$\mathrm{MH}=$ Torque máximo atingido ( $\mathrm{dN} . \mathrm{m})$, que reflete razoavelmente o módulo do vulcanizado.

$\mathrm{T}_{\mathrm{S} 1}$ = tempo, em minutos, necessário para aumentar o torque mínimo $\mathrm{ML}$ em uma unidade de torque.

$\mathrm{T}_{\mathrm{S} 2}=$ tempo, em minutos, necessário para aumentar o torque mínimo $\mathrm{ML}$ em duas unidades de torque.

$\mathrm{T}_{90}=$ tempo, em minutos, necessário para que o torque atinja o valor de $\mathrm{ML}+$ 0,9 (MH - ML). Também chamado de tempo ótimo de vulcanização, que é o tempo necessário para atingir $90 \%$ do torque máximo.

$\mathrm{T}_{\mathrm{MH}}\left(\mathrm{ou} \mathrm{T}_{100}\right)$ = tempo, em minutos, necessário para que o torque atinja o valor máximo $(\mathrm{MH})^{59}$. 
Para esse trabalho, foi definido o tempo de vulcanização como o tempo necessário para que seja alcançado o $\mathrm{T}_{90}$ em cada formulação.

\subsubsection{Viscosidade Mooney}

Os testes de viscosidade Mooney foram realizados em um viscosímetro da marca Alpha Technologies modelo MV 2000. O viscosímetro Mooney determina a viscosidade do elastômero puro e/ou da composição não vulcanizada, em função da resistência ao cisalhamento ${ }^{57}$.

O viscosímetro Mooney consiste essencialmente de um rotor de metal, que gira a uma velocidade de 2 rpm, conforme indicado na FIG. 32. Existem dois rotores padrões para o teste de viscosidade Mooney: o rotor grande (L) com diâmetro de 1,5 \pm 0,001" (usado para polímeros e composições de baixa viscosidade) e o rotor pequeno (S) com diâmetro de 1,2 \pm 0,001" (usado para polímeros e composições de alta viscosidade).

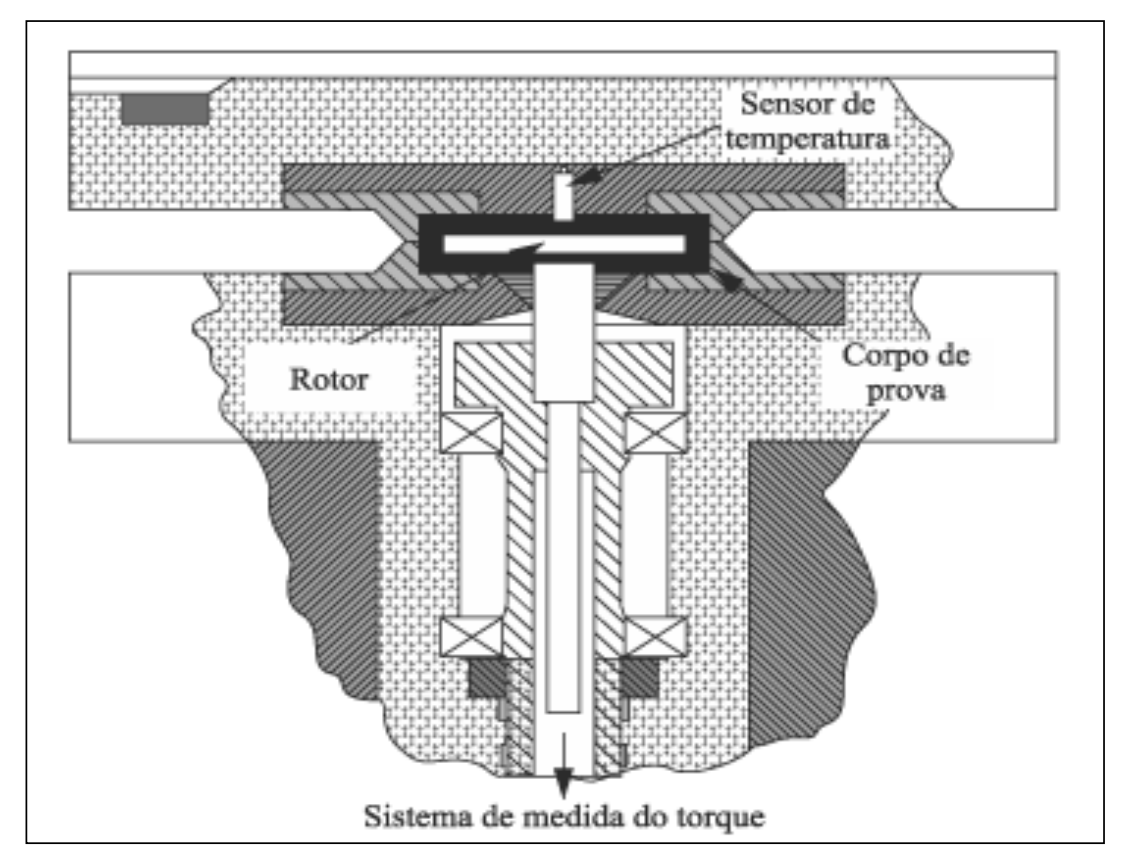

FIGURA 32: Esquema da cavidade de teste de viscosímetro Mooney ${ }^{60}$.

A temperatura do ensaio é normalmente de $100^{\circ} \mathrm{C}$, porém outras temperaturas também podem ser usadas. O corpo-de-prova consiste de duas partes do material a ser testado, com diâmetros e espessuras suficientes para 
preencher totalmente a cavidade do aparelho. As duas partes do corpo de prova envolvem o rotor de metal, que gira lenta e continuamente por determinado período de tempo. A resistência à rotação é medida em unidades arbitrárias como viscosidade Mooney ${ }^{60}$ e é apresentada da seguinte forma, na EQ. 4:

$50-\mathrm{ML} 1+4\left(100^{\circ} \mathrm{C}\right)$

onde:

50 - indica viscosidade (unidades);

M - indica Mooney;

$\mathrm{L}$ - indica o tipo do rotor usado (grande);

1 - indica o tempo de pré-aquecimento, em minutos

4 - indica o tempo do ensaio contado após a partida do rotor, em minutos

$\left(100{ }^{\circ} \mathrm{C}\right)$ - indica a temperatura do ensaio.

Foi utilizada a norma ASTM D-1646 ${ }^{151151}$, para determinação da viscosidade Mooney. Quanto maior for à viscosidade, menor a plasticidade do elastômero ou da composição.

\subsubsection{Microscopia eletrônica de varredura (MEV)}

A caracterização da morfologia das composições de borrachas butílicas e halobutílicas, com os diferentes sistemas de cura, foram realizadas utilizando EDS (sistema de energia dispersiva); em microscópio eletrônico da marca HITACHI, modelo TM 3000, alocado no Centro de Ciência e Tecnologia de Materiais (CCTM) do IPEN-CNEN/SP.

As amostras foram analisadas no ponto de ruptura do corpo de prova submetido ao teste de tração e alongamento e aumentado 200 e 250 vezes. 


\subsubsection{Análise mecânico-dinâmica (DMA)}

A análise Mecânica Dinâmica foi utilizada para a determinação o módulo de elasticidade (módulo de armazenamento ou, E'), módulo viscoso (ou módulo de perda, E") e coeficiente de amortecimento (Tanঠ= E"/E'), em função da frequência da temperatura ou do tempo. Os testes foram realizados num equipamento de DMA 50 da marca Metravib.

\subsection{Obtenção de compostos contendo borracha recuperada/reciclada}

As amostras de borrachas butílicas e halobutílicas curadas com resina, enxofre e doador de enxofre irradiadas na dose de 25 kGy e posteriormente cisalhadas foram escolhidas como ponto de partida para realizar os testes de mistura de borracha recuperada com borracha virgem. Os resultados das análises mostraram que, para essa dose de irradiação seguida de cisalhamento, em todas as borrachas, ocorreram cisão de cadeia e de reticulação, sem degradação acentuada da cadeia polimérica.

A capacidade do material revulcanizar foi testada por meio da mistura da borracha desvulcanizada por irradiação e posteriormente cisalhada com partes de borracha virgem em formulações já pré-determinadas.

\subsection{Materiais reciclados}

Para todas as amostras foram efetuadas as combinações de $70 \mathrm{phr}$ de borracha virgem com 30 phr de borracha irradiada a 25 kGy e cisalhada. As amostras contendo $30 \mathrm{phr}$ de borracha recuperada, foram denominadas com a sigla RC (TAB. 8), e a numeração refere-se à formulação do composto. 
TABELA 8 : Nomenclatura das borrachas butílica e halobutílica confeccionadas com 30 phr de borracha irradiada e cisalhada.

\begin{tabular}{|l} 
RC $1=$ formulação de borracha butílica com borracha butílica \\
recuperada curada com resina. \\
\hline $\mathrm{RC} 2=$ formulação de borracha butílica com borracha butílica \\
recuperada curada com enxofre. \\
RC $3=$ formulação de borracha butílica com borracha butílica \\
recuperada curada com doador de enxofre. \\
\hline RC $4=$ formulação de borracha bromobutílica com borracha \\
bromobutílica recuperada curada com resina. \\
\hline RC $5=$ formulação de borracha bromobutílica com borracha \\
bromobutílica recuperada curada com enxofre. \\
\hline RC 6 formulação de borracha bromobutílica com borracha \\
bromobutílica recuperada curada com doador de enxofre.
\end{tabular}

As formulações dos compostos de borrachas butílica e halobutílica confeccionados com 70 phr de borracha virgem e 30 phr de borracha recuperada (irradiada a 25 kGy e cisalhada) estão mostrados na TAB 9. 
TABELA 9: Formulações de borrachas butílica e halobutílica misturadas com as borrachas butílicas e halobutílicas irradiadas a 25 kGy e posterior mente cisalhadas.

\begin{tabular}{|c|c|c|c|c|c|c|c|c|c|}
\hline Ingredientes & $\begin{array}{l}\text { RC1 } \\
\text { (phr) }\end{array}$ & $\begin{array}{l}\text { RC2 } \\
\text { (phr) }\end{array}$ & $\begin{array}{l}\text { RC3 } \\
\text { (phr) }\end{array}$ & $\begin{array}{l}\text { RC4 } \\
\text { (phr) }\end{array}$ & $\begin{array}{l}\text { RC5 } \\
\text { (phr) }\end{array}$ & $\begin{array}{l}\text { RC6 } \\
\text { (phr) }\end{array}$ & $\begin{array}{l}\text { RC7 } \\
\text { phr) }\end{array}$ & $\begin{array}{l}\text { RC8 } \\
\text { (phr) }\end{array}$ & $\begin{array}{l}\text { RC9 } \\
\text { (phr) }\end{array}$ \\
\hline Bor. Butílica & 70 & 70 & 70 & - & - & - & - & - & - \\
\hline Bor. Bromobutílica & - & - & - & 70 & 70 & 70 & - & - & - \\
\hline Bor. Clorobutílica & - & - & - & - & - & - & 70 & 70 & 70 \\
\hline Bor. Cloropreno & 5 & - & - & - & - & - & - & - & - \\
\hline $\begin{array}{c}\text { Bor. Butílica } \\
\text { irradiada ( } 25 \text { kGy) } \\
\text { e cisalhada }\end{array}$ & 30 & 30 & 30 & & - & - & - & - & - \\
\hline $\begin{array}{c}\text { Bor. Bromobutílica } \\
\text { irradiada ( } 25 \mathrm{kGy}) \\
\text { e cisalhada }\end{array}$ & - & - & - & 30 & 30 & 30 & - & - & - \\
\hline $\begin{array}{c}\text { Bor. Clorobutílica } \\
\text { irradiada ( } 25 \mathrm{kGy}) \\
\text { e cisalhada }\end{array}$ & - & - & - & - & - & & 30 & 30 & 30 \\
\hline Óxido de Zinco & 5 & 5 & 5 & 5 & 3 & 5 & 5 & 5 & 5 \\
\hline Estearina & 0,5 & 1 & 1,5 & 0,5 & 1 & 1 & 0,5 & 1 & 1 \\
\hline $\begin{array}{l}\text { Òxido de } \\
\text { Magnésio }\end{array}$ & - & - & - & - & - & - & - & 0,5 & 0,3 \\
\hline Plastificante & 5 & 25 & 20 & 5 & 25 & 25 & 5 & 28 & 15 \\
\hline $\begin{array}{l}\text { Negro de Fumo } \\
\text { N } 330\end{array}$ & 60 & 70 & 50 & 60 & 70 & 70 & 60 & 75 & 50 \\
\hline Resina Fenólica & 10 & - & - & 10 & - & - & 10 & - & - \\
\hline Enxofre & - & 2 & - & - & 0,5 & - & - & 0,5 & - \\
\hline TMTD & - & 1 & 1,75 & - & - & 1,0 & - & - & - \\
\hline MBTS & - & 0,5 & 1,0 & - & 0,5 & 2,0 & - & - & - \\
\hline ZMDC & - & - & - & - & 0,1 & - & - & - & - \\
\hline ZBDC & - & - & - & - & - & - & - & - & 2 \\
\hline ZBEC & - & - & - & - & - & - & - & 2 & - \\
\hline
\end{tabular}


Os compostos de borrachas foram preparados em um misturador de dois rolos da marca Copê e depois de misturados, foram analisados para determinar as medidas reológicas e determinar o tempo ótimo de cura. Para efeito comparativo foram preparados compostos de borrachas butílicas e halobutílicas sem a adição de borrachas irradiadas e cisalhadas. A FIG. 33 apresenta um fluxograma com os processos e análises realizados nos compostos contendo 70 phr de borracha virgem e 30 phr de borracha de borracha irradiada (25 kGy) e cisalhada.

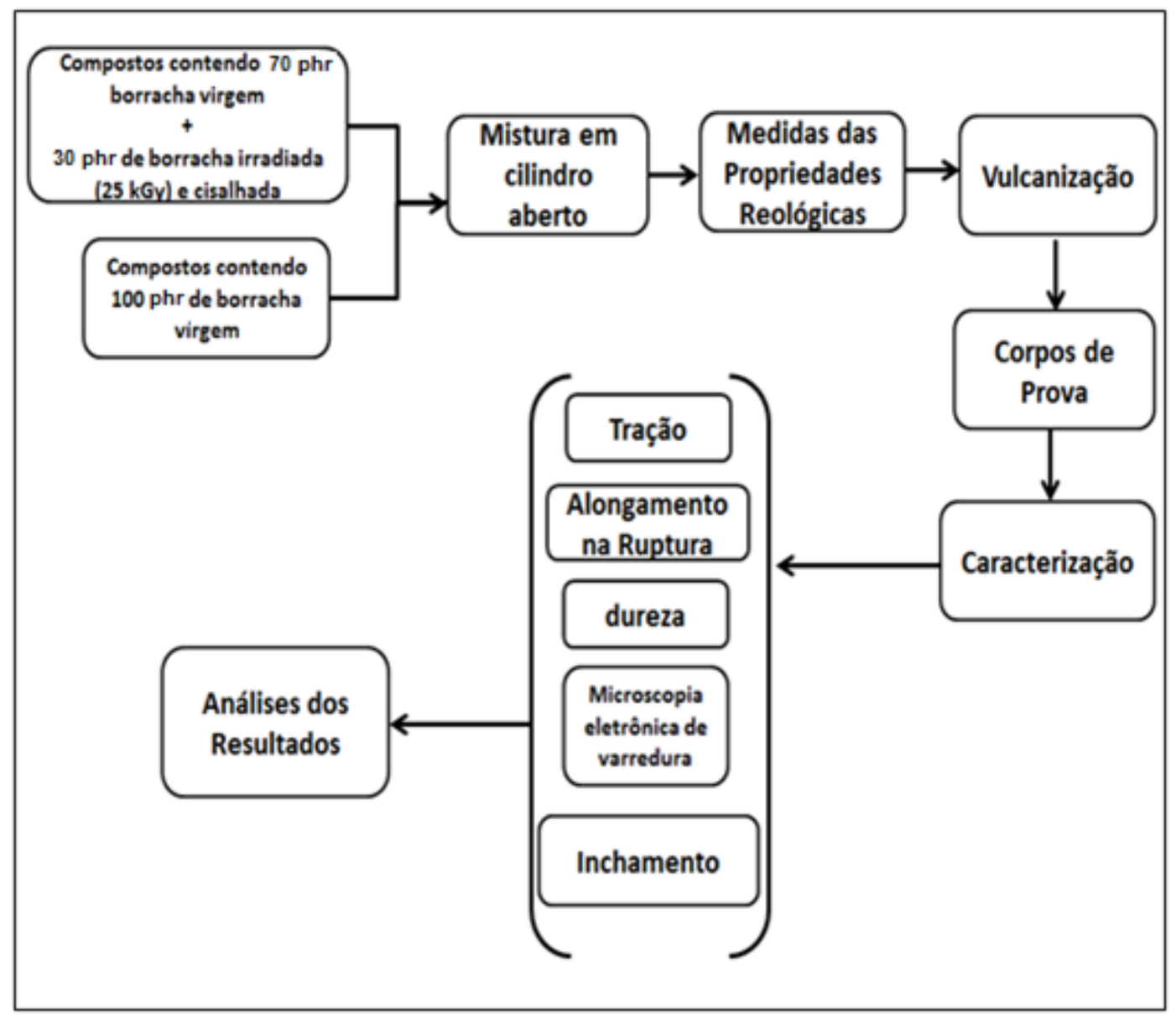

FIGURA 33: Fluxograma do processo de mistura das amostras de borrachas butílica e halobutílica contendo 70 phr de borracha virgem e 30 phr de borracha irradiada ( $25 \mathrm{kGy}$ ) e cisalhadas e das amostras das borrachas contendo 100 phr de borracha virgem. 
As temperaturas empregadas para a vulcanização dos compostos elastoméricos contendo 30 phr de borracha butílica e halobutílicas (bromo e cloro) irradiadas (25 kGy) e cisalhadas foram às mesmas que as empregadas para vulcanizar os compostos de borrachas butílicas e halobutílicas, contendo 100 phrde borracha virgem.

Foram cortados corpos de prova específicos para os ensaios mecânicos propostos: resistência à tração e alongamento na ruptura (ASTM D 412-08) e dureza Shore A (ASTM D 2240-08).

Os testes de inchamento (ASTM D-3616) foram realizados de modo similar ao das amostras irradiadas e irradiadas e cisalhadas, com corpos de prova nas dimensões aproximadas $1,5 \times 1,5 \mathrm{~cm}^{2}$ previamente pesados e imersos em tolueno até estabilização do peso (mais ou menos cinco dias). Ao término do ensaio os corpos de prova foram secos à temperatura ambiente por 24 horas e pesados novamente. 
$5 \quad$ RESULTADOS E DISCUSSÕES

\subsection{Efeito da radiação na viscosidade das borrachas butílicas}

Os resultados da irradiação na viscosidade Mooney das borrachas butílica, bromobutílica e clorobutílica (não vulcanizada), estão mostrados na FIG. 34. A viscosidade foi medida após 1 minuto de pré-aquecimento, seguida por 4 minutos de ação de cisalhamento na temperatura de $100^{\circ} \mathrm{C}$.

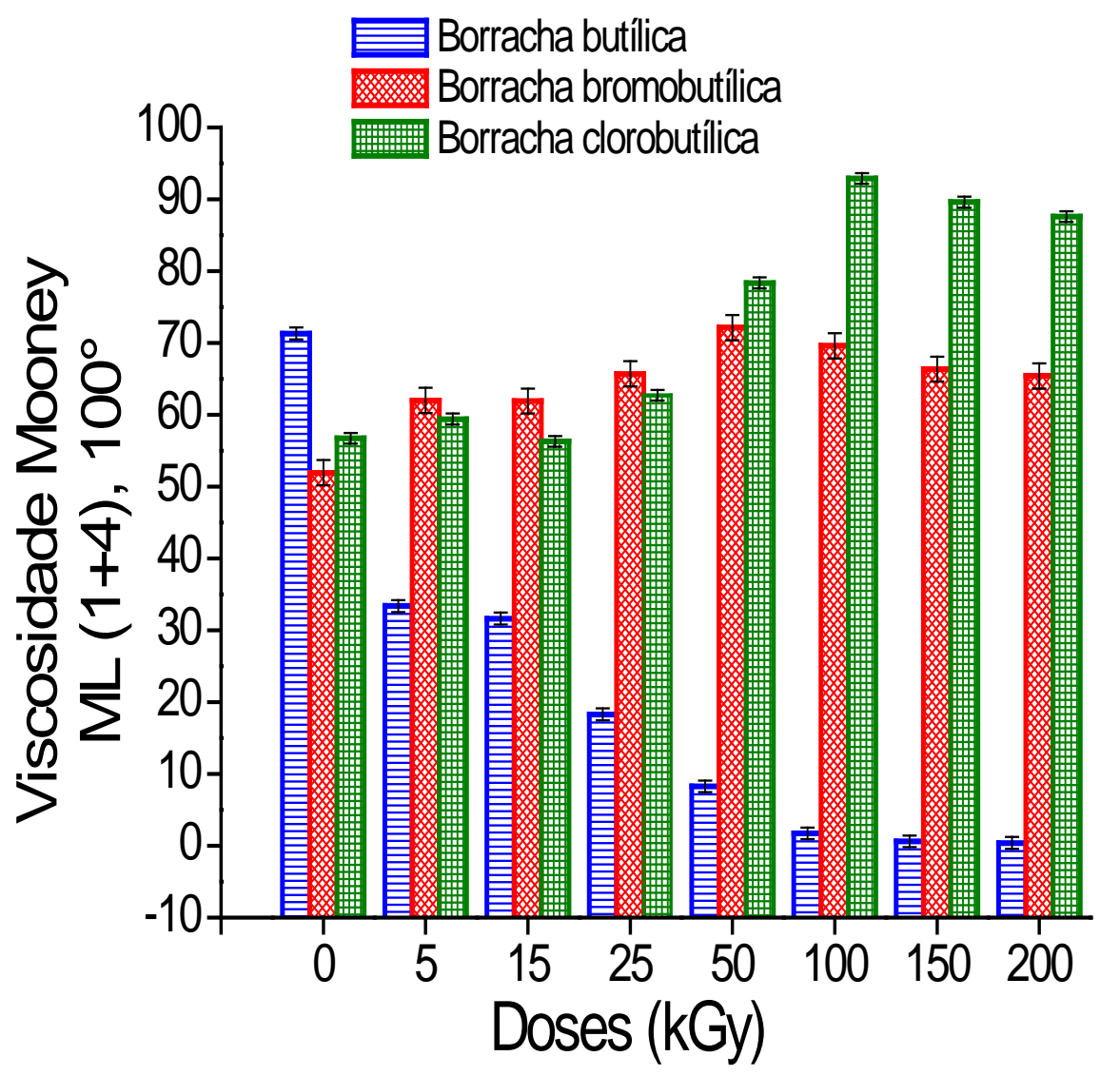

FIGURA 34: Viscosidade Mooney da borracha butílica, bromobutílica e clorobutílica irradiada e não irradiada. Butílica (azul), bromobutílica (vermelho) e clorobutílica (verde). 
A borracha butílica apresenta decréscimo acentuado de viscosidade até a dose de 100 kGy, mas o decréscimo é muito intenso já na dose de 5 kGy, indicando o predomínio total da cisão de cadeia. Observa-se que entre as doses de 100 a 200 kGy um equilíbrio de valores sugerindo a ocorrência simultânea de cisão e reticulação ou a existência de oxidação generalizada criando reticulações e ponte de hidrogênio que contrabalançam parcialmente as cisões induzidas por radiação.

Para as borrachas halogenadas clorobutílica e bromobutílica observam-se pequenos aumentos e decréscimos dos valores de viscosidade até a dose de 200 kGy indicando a presença simultânea de cisão e reticulação ${ }^{107}$ ou o domínio das forças intermoleculares oriundas das ligações de hidrogênio.

A figura 35 mostra a reação intramolecular das borrachas halobutílicas (bromo e cloro), ilustrando a reação de reticulações destas borrachas depois da irradiação. A afinidade dos halogêneos por átomos de hidrogênio facilita a produção de ácido halogenado por interação atómica direta (reação de abstração de $\mathrm{H})^{117}$.

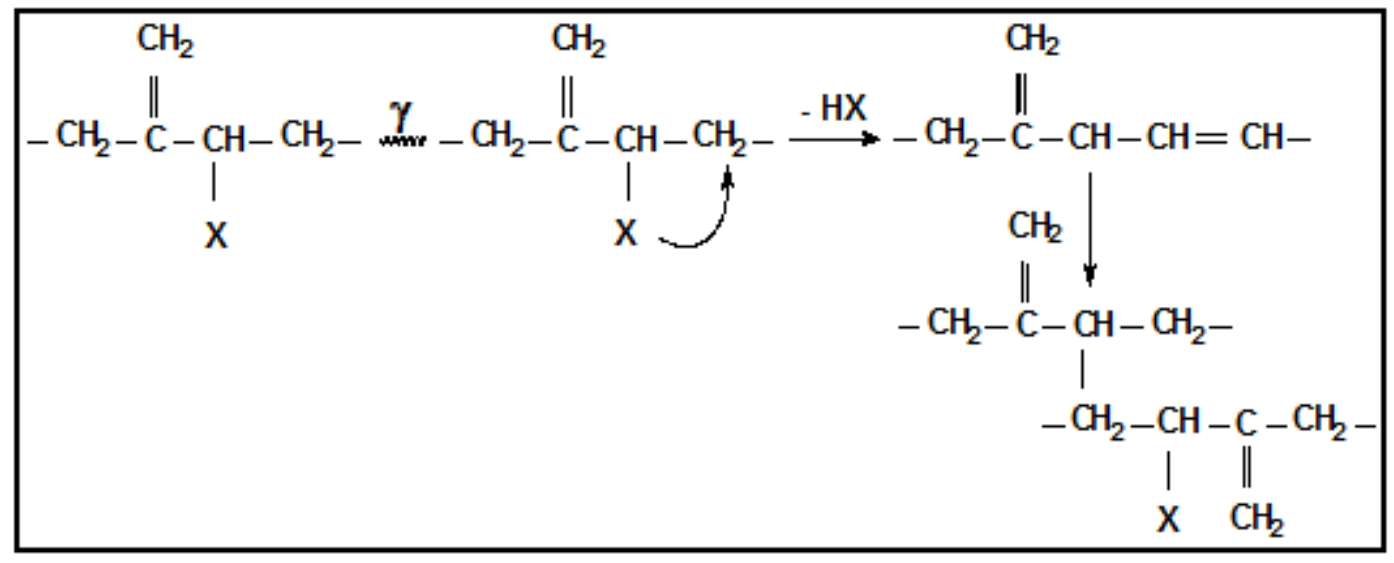

FIGURA 35: Reação intramolecular envolvendo formação de reticulação ${ }^{117}$.

A FIG. 36 mostra 0 aspecto visual das borrachas butílicas, bromobutílicas e clorobutílicas (matéria-prima), antes e depois da irradiação. 


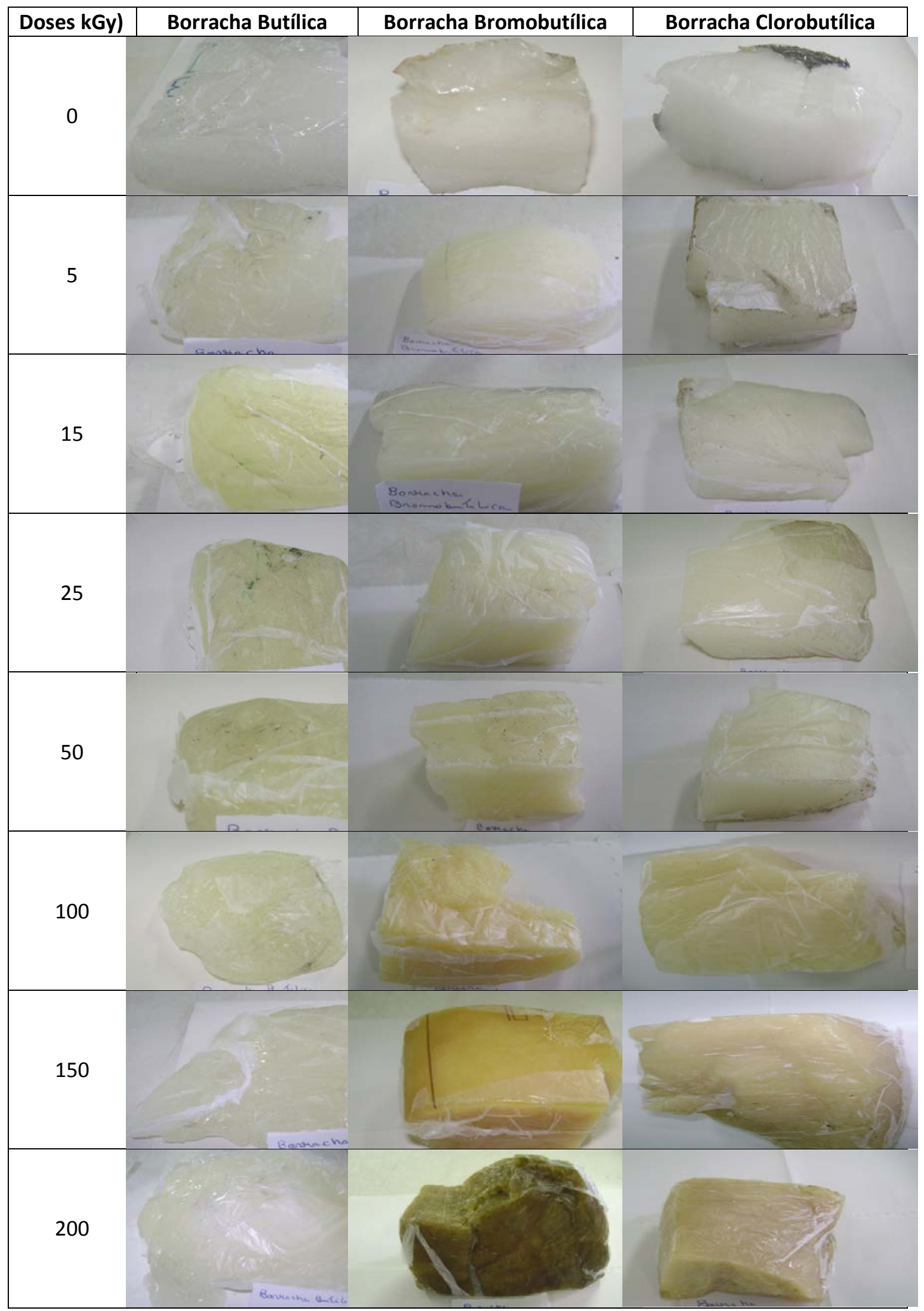

FIGURA 36: Aspecto visual das borrachas butílicas, bromobutílicas e clorobutílicas antes e depois de irradiar nas doses de 0, 5, 15, 25, 50, 100,150 e 200 kGy. 
Observou-se que a borracha butílica, apresentou escurecimento e mudança de forma com o aumento da dose até 200 kGy, corroborando o fenômeno de diminuição da viscosidade observado na FIG.34.

Observou-se que as borrachas halobutílicas mudaram de cor com o aumento da dose. Possivelmente, em consequência da ampla geração de duplas ligações formadas pela intensa cisão de cadeia seguida de oxidação. Notou-se também que as borrachas halogenadas para doses mais elevadas foram as que mostraram escurecimento mais intenso e aspecto visual rígido, sugerindo maior formação de reticulação em virtude do aumento de duplas ligações. Existe também a presença de grupos funcionais decorrentes da oxidação da molécula favorecendo também a descoloração ${ }^{107,117}$.

\subsection{Efeito da radiação nos parâmetros reométricos de vulcanização}

O processo de vulcanização consiste em ligar quimicamente as moléculas do polímero em vários pontos ao longo da cadeia, por meio de ligações covalentes visando a formação de uma rede tridimensional elástica que confere à borracha as propriedades desejadas. Embora este processo seja basicamente de natureza química, os testes usuais para avaliação da vulcanização do material são baseados em mudanças físicas que ocorrem no material. Dentre os principais parâmetros a serem avaliados destacam-se: o tempo ótimo de vulcanização $\left(T_{90}\right)$, o torque mínimo $(\mathrm{ML})$ e o torque máximo $(\mathrm{MH})^{60}$.

A quantidade de ligações cruzadas formadas durante o processo de vulcanização do material depende dos seguintes fatores: temperatura, tipo de borracha e sistema de cura empregado ${ }^{152}$. Os ensaios forneceram os seguintes dados além da própria curva reométrica: $\mathrm{ML}=$ torque mínimo atingido; $\mathrm{MH}=$ torque máximo atingido. 
A TAB. 10 apresenta o tempo ótimo de cura para todas as formulações de borachas butílica e halobutílica.

TABELA 10: Tempo ( $\left.T_{90}\right)$ de vulcanização dos compostos de borrachas butílica, bromobutílica e clorobutílica.

\begin{tabular}{l|c|c}
\hline \multicolumn{1}{c|}{ Amostras } & $\begin{array}{c}\left(\mathrm{T}_{90}\right) \\
\text { (minutos) }\end{array}$ & $\begin{array}{c}\text { Temperaturas de } \\
\text { Vulcanização } \\
\left({ }^{\circ} \mathrm{C}\right)\end{array}$ \\
\hline Am. 1 (butílica curada com resina) & 20 & 190 \\
\hline Am. 2 (butílica curada com enxofre) & 4,0 & 180 \\
\hline Am. 3 (butílica curada com doador de enxofre) & 3,0 & 180 \\
\hline \hline Am. 4 (bromobutílica curada com resina) & 12 & 190 \\
\hline Am. 5 (bromobutílica curada com enxofre) & 4,0 & 180 \\
\hline $\begin{array}{l}\text { Am. 6 (bromobutílica curada com doador de } \\
\text { enxofre) }\end{array}$ & 3,5 & 180 \\
\hline \hline Am. 7 (clorobutílica curada com resina) & 8,0 & 190 \\
\hline Am. 8 (clorobutílica curada com enxofre) & 2,0 & 180 \\
\hline $\begin{array}{l}\text { Am. 9 (clorobutílica curada com doador de } \\
\text { enxofre) }\end{array}$ & 3,0 & 180 \\
\hline
\end{tabular}

Observa-se que o tempo de vulcanização dos compostos de borrachas butílica, bromobutílica e clorobutílica curados com resina, apresentam tempo e temperatura de vulcanização mais elevados em relação aos compostos de borrachas butílica, bromobutílica e clorobutílica, curadas com enxofre e doador de enxofre, em virtude da baixa reatividade das resinas fenólicas.

\subsubsection{Torque máximo $(\mathrm{MH})$ dos compostos de borrachas butílica e halobutílica irradiadas}

Os resultados de torque máximo obtidos para todas as borrachas butílicas, bromobutílicas e clorobutílicas, curadas com resina, enxofre e doador de enxofre, são mostrados na FIG. 37. 
O torque máximo está relacionado com o aumento da rigidez da rede elastomérica quando, praticamente ocorreu toda reticulação. Esta rigidez está associada à densidade das ligações cruzadas formadas ${ }^{153}$.

Observou-se para a amostra 1 (butílica curado com resina), amostra 2 (butílica curada com enxofre) e amostra 3 (butílica curada com doador de enxofre), comportamento similar ao da borracha butílica (matéria-prima), ou seja, decréscimo acentuado nos valores de torque entre 0 kGy e 100 kGy e diminuição de valores menos acentuado entre 150 e 200 kGy.

As borrachas halogenadas (cloro e bromo) também mostraram decréscimo de valores com a dose. Ocorreu a predominância de cisão de cadeia, com um decréscimo de 40\% nos valores de $\mathrm{MH}$, indicando diminuição da quantidade de ligações cruzadas formadas. Para doses acima de 100 kGy observou-se uma manutenção do torque, sugerindo balanço entre cisão e reticulação, ambos proporcionais às doses aplicadas. 
(a)
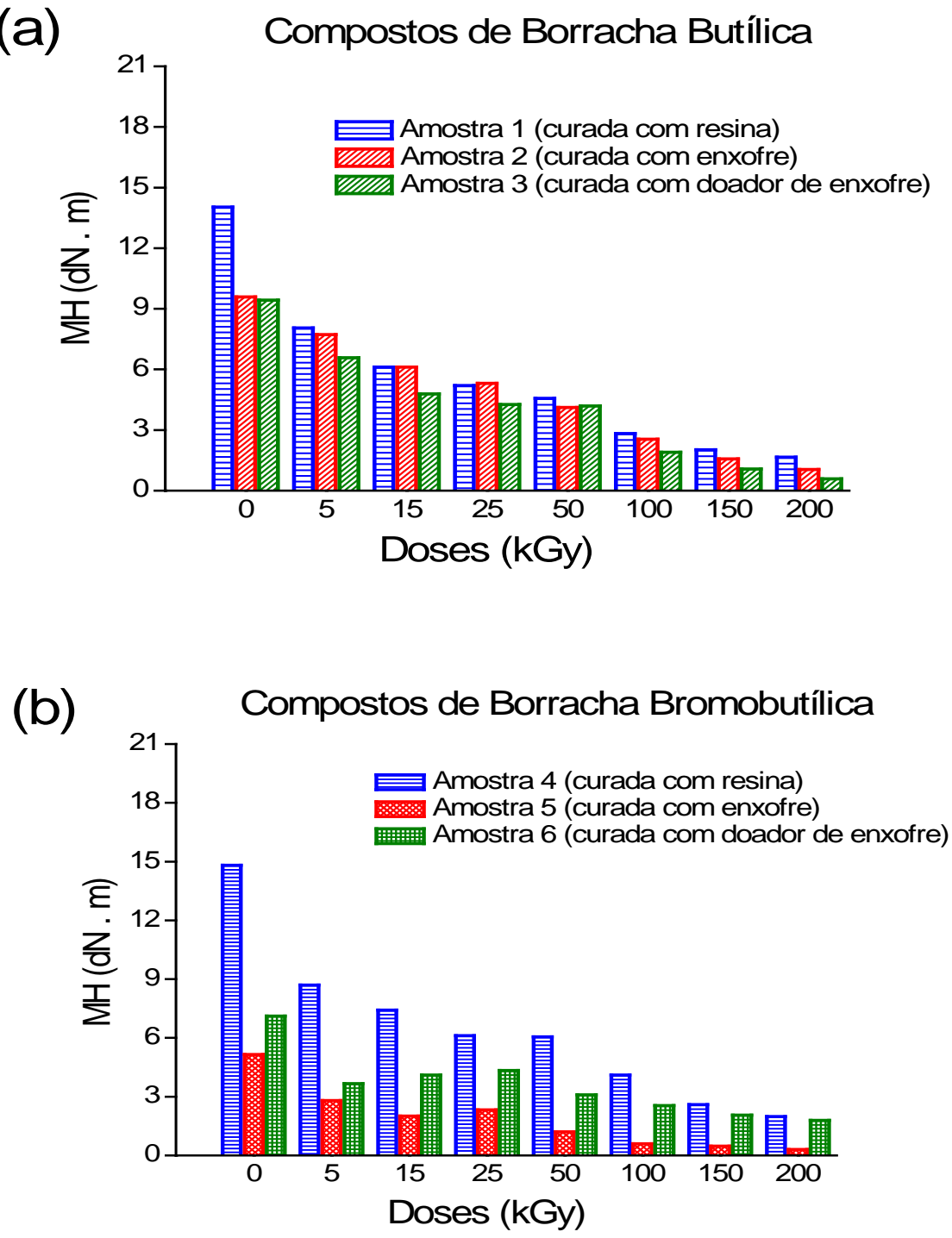

(c)

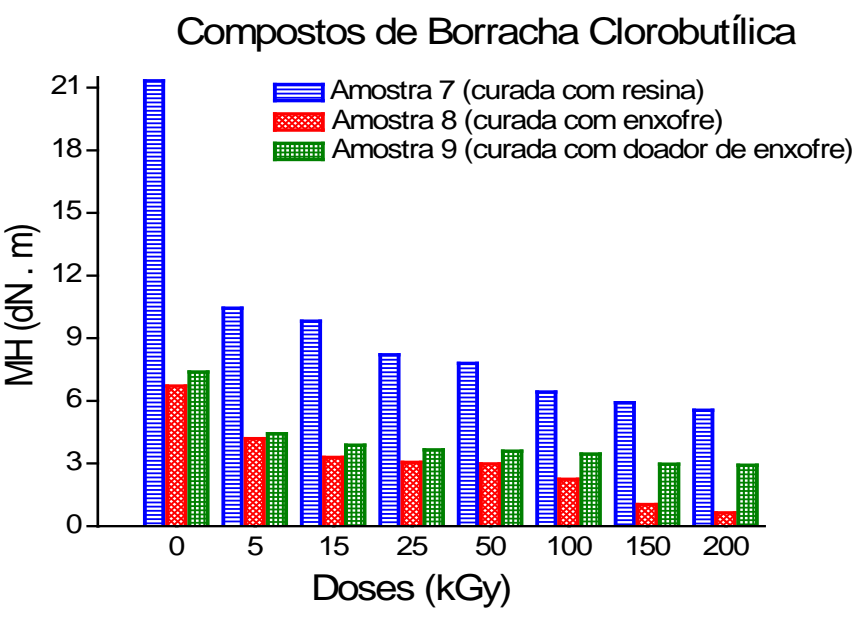

FIGURA 37: Torque máximo dos compostos de (a) borracha butílica, (b) borracha bromobutílica e (c) borracha clorobutílica irradiada e não irradiada. Curada com resina (azul), enxofre (vermelho) e doador de enxofre (verde). 


\subsubsection{Torque máximo $(\mathrm{MH})$ dos compostos de borrachas butílica e halobutílica irradiadas e cisalhadas}

Os resultados obtidos de $\mathrm{MH}$, para as amostras irradiadas e cisalhadas das borrachas butílica, bromobutílica e clorobutílica curadas com resina, enxofre e doador de enxofre, são mostrados na FIG.38.

Os compostos de borrachas butílicas e halobutílicas não irradiadas (0 kGy) não foram cisalhados: pois o cisalhamento realizado em cilindro provoca degradação intensa nas moléculas das borrachas vulcanizadas. Para as amostras irradiadas, o cisalhamento intenso não ocasionou ampla degradação principalmente para doses baixas (menores que $50 \mathrm{kGy}$ ).

Observou-se na FIG 38, do torque máximo da borracha butílica curada com resina (amostra 1), equilíbrio de valores até a dose de $50 \mathrm{kGy}$, indicando a ocorrência simultânea de cisão e reticulação. Verificou-se a predominância da reticulação, provavelmente em razão da baixa taxa de cura deste composto, que com o novo aquecimento provocado pelo cisalhamento da mistura em cilindro aberto e formaram novos pontos de reticulação.

Para doses superiores a 100 kGy, verificou-se uma ligeira diminuição de valores de torque, sugerindo também o equilíbrio entre cisão e reticulação. Entretanto a dominância é de cisão de cadeia, com consequente diminuição da massa molar. Isto indica que a intensa formação de radicais livres não promoveu novos pontos de reticulação. 

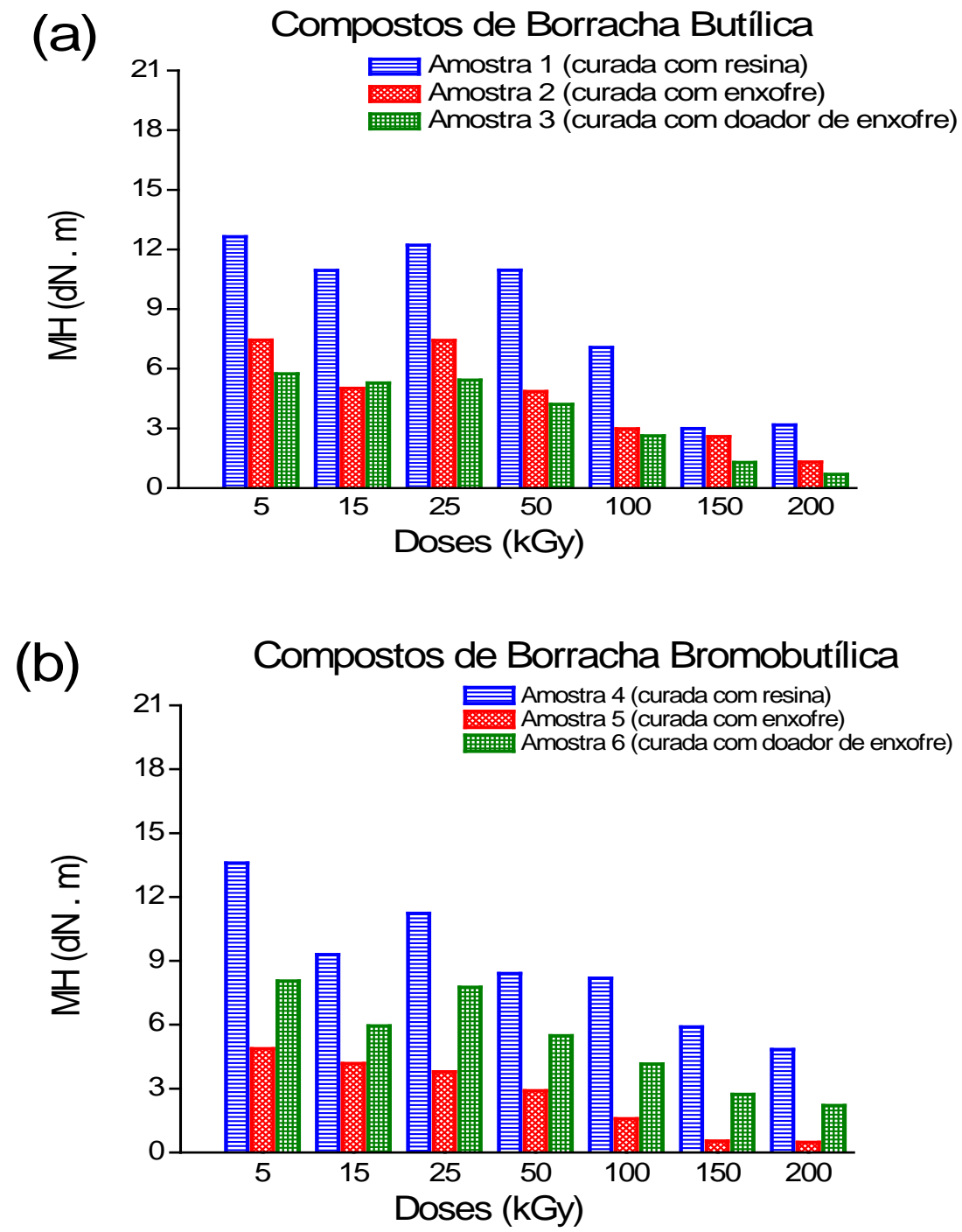

(c)

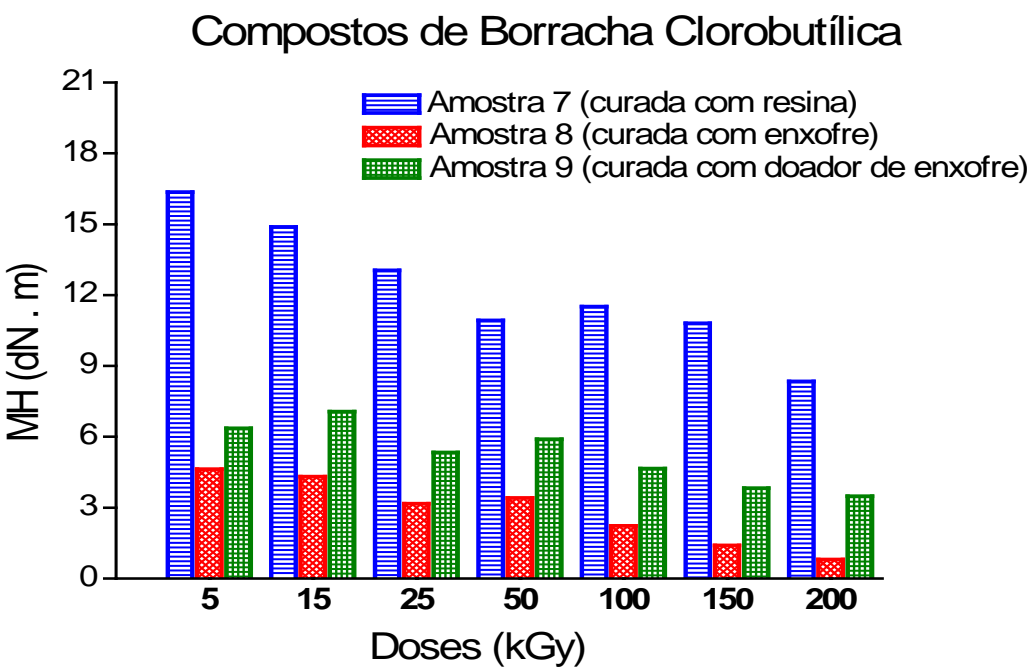

FIGURA 38: Efeito da dose de irradiação seguido de cisalhamento para torque máximo dos compostos de (a) borracha butílica, (b) borracha bromobutílica e (c) borracha clorobutílica. Curada com resina (azul), enxofre (vermelho) e doador de enxofre (verde). 
Para os compostos de borracha butílica, curados com enxofre e doador de enxofre (amostras 2 e 3) se observa que, em baixas doses, há a ocorrência simultânea de cisão e reticulação. Para doses superiores a 50 kGy, há a degradação da cadeia polimérica, em virtude da intensa quebra mecânica das moléculas da borracha.

Os compostos de borrachas bromobutílicas e clorobutílicas curados com resina (amostras 4 e 7) mostraram ligeiro decréscimo de torque entre as doses de 5 kGy e 25 kGy. Isto sugere a ocorrência simultânea de cisão e reticulação, com predomínio da cisão. Para doses entre 50 kGy e 100 kGy equilíbrio nos valores de torque. Em dose superior a 100 kGy leve decréscimo de valores de torque, provavelmente pela degradação oxidativa do polímero.

Para os compostos curados com doador de enxofre (amostras 6 e 9), verifica-se que, para doses de até 50 kGy, equilíbrio nos valores de torque, sugerindo ocorrência simultânea de cisão e reticulação. Em doses acima de 100 kGy, observou-se decréscimo de torque, provavelmente pela degradação do polímero, com maior intensidade para os compostos de borracha bromobutílica. Indicando maior estabilidade das borrachas clorobutílicas em virtude da energia de ligação do C-Br ser ligeiramente menor que a energia de ligação do $\mathrm{C}-\mathrm{Cl}$.

Notou-se também que as borrachas halobutílicas, curadas com enxofre (amostras 5 e 8), para doses superiores a $100 \mathrm{kGy}$, foram as que mostraram degradação mais intensa da borracha. Provavelmente ocasionada pela mastigação mecânica e ruptura das ligações de reticulação do tipo polissulfídicas, consideradas mais fracas que as ligações monossulfídicas e dissulfídicas.

\subsubsection{Torque mínimo (ML) dos compostos de borrachas butílica e halobutílica irradiadas}

Os resultados de torque mínimo (ML) dos compostos irradiados e não irradiados para as borrachas butílica, bromobutílica e clorobutílica curadas com resina, enxofre e doador de enxofre; são mostrados na FIG. 39. 
(a)

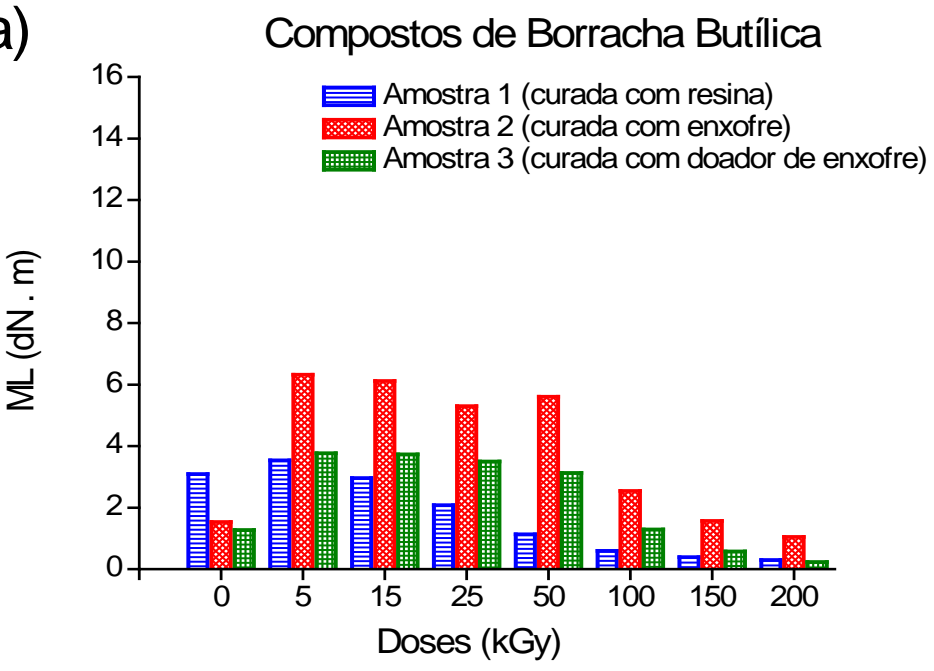

(b)

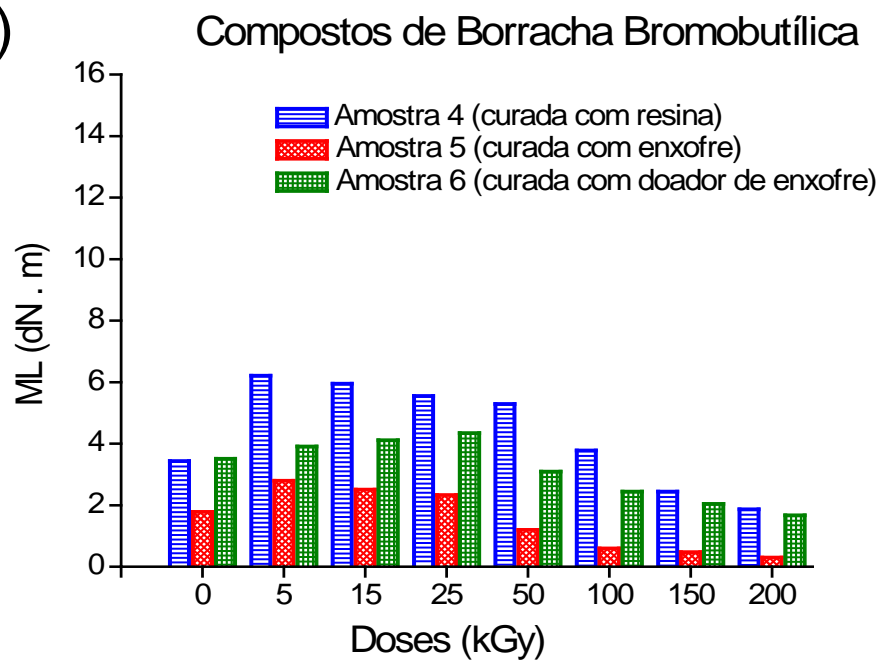

(c)

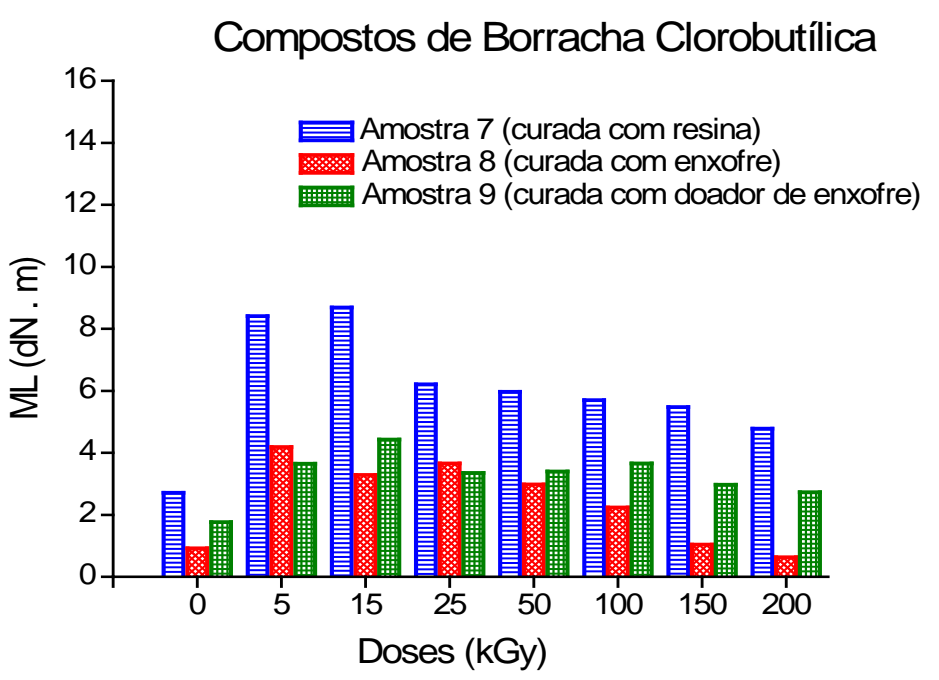

FIGURA 39: Torque mínimo dos compostos de (a) borracha butílica, (b) borracha bromobutílica e (c) borracha clorobutílica irradiada e não irradiada. Curada com resina (azul), enxofre (vermelho) e doador de enxofre (verde). 
O torque mínimo está relacionado à viscosidade da composição na temperatura do ensaio, e, dessa forma, é um indicativo da processabilidade ${ }^{154}$.

Na FIG. 39 os resultados de ML dos compostos de borrachas butílicas e halobutílicas curados com resina, enxofre e doador de enxofre, mostram que, para todos os tipos de borracha, independente do sistema de cura, houve aumento de torque após a irradiação. Indicando aumento na formação de ligações cruzadas.

Os compostos de borracha butílica curada com resina (amostra 1) mostraram o decréscimo dos valores de torque para doses de até 50 kGy. Para doses superiores a 50 kGy, observou-se decréscimo mais acentuado de valores sugerindo a degradação da borracha pela formação de estruturas cícilicas menos estáveis à radiação, visto que a cura por resina forma estruturas cíclica mais fáceis de romperem, após a formação de radicais livres.

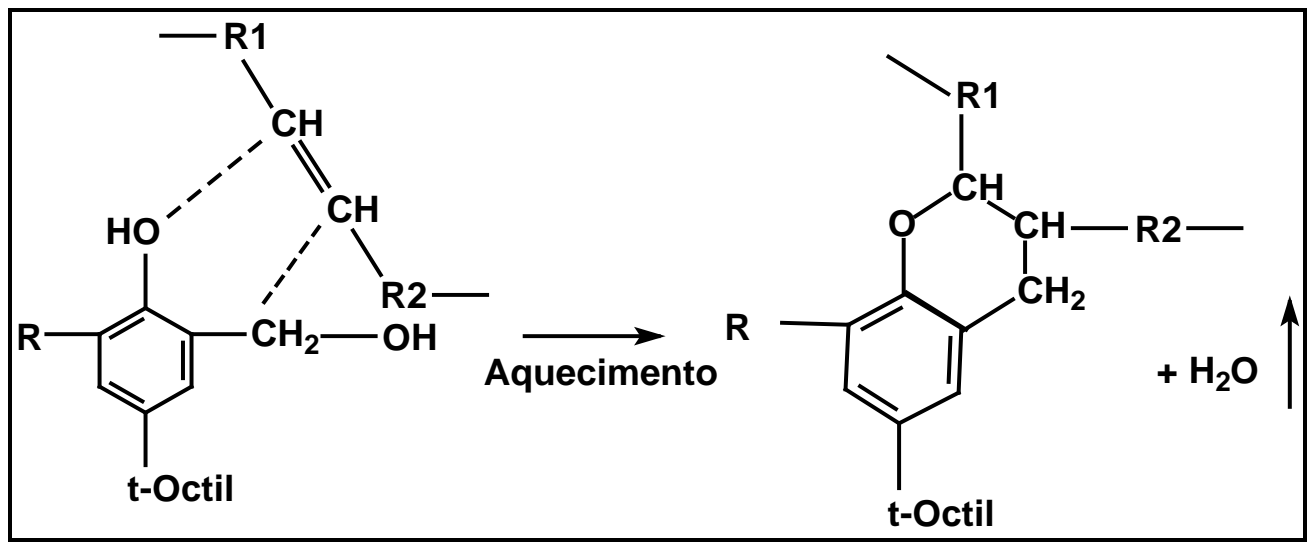

FIGURA 40: Estrutura cíclica de reticulação por resina na borracha butílica ${ }^{81}$.

Os compostos de borracha butílica curados com enxofre e doador de enxofre (amostras 2 e 3) apresentaram acréscimo acentuado de valores de ML, indicando aumento de viscosidade até a dose de 50 kGy sugerindo a competição entre cisão e reticulação.

Para o composto de borracha bromobutílica curada com resina (amostra 4), observou-se a equivalência entre os valores de torque, até a dose de 50 kGy; que é um indicativo da ocorrência simultânea de cisão e reticulação. Já 
para doses superiores a $50 \mathrm{kGy}$, se verifica o decréscimo de valores de torque proporcional a dose, evidênciando-se a predominância da cisão de cadeia.

$\mathrm{Na}$ amostra 5 (bromobutílica curada com enxofre) e a amostra 6 (bromobutílica, curada com doador de enxofre), observou-se que para doses de até 25 kGy, similaridade de valores de torque, sugerindo a ocorrência simultanea de cisão e reticulação, com predominância de reticulação. Para doses entre 50kGy e 200 kGy decréscimo dos valores de torque mínimo, mais acentuado para a borracha bromobutílica curada com enxofre (amostra 5), provavelmente pela intensa cisão de cadeia.

A borracha clorobutílica, curada com resina (amostra 7), apresentou acréscimo abrupto de torque mínimo para doses de 5 kGy e 15 kGy, sugerindo cisão de cadeia e reticulação. Para doses de 25 kGy a 200 kGy mostrou leve decréscimo no valor do torque, indicando, a ocorrência simultânea de cisão e reticulação com predomínio da cisão.

As amostras de borracha clorobutílica, curadas com enxofre e doador de enxofre (amostra 8 e amostra 9), também apresentaram equilíbrio de valores de torque nas doses entre e 50 kGy, indicando a ocorrência de cisão e reticulação, com predominância de reticulação. Para doses superiores a 100 kGy, os valores de torque mostram decréscimo, indicando a tendência à cisão de cadeia.

\subsubsection{Torque mínimo (ML) dos compostos de borrachas butílica e halobutílica irradiadas e cisalhadas}

Os resultados obtidos de torque mínimo (ML) para as amostras, de borrachas butílicas, bromobutílicas e clorobutílicas curadas com resina, enxofre e doador de enxofre irradiadas e cisalhadas, estão mostrados na FIG. 41. 
(a)
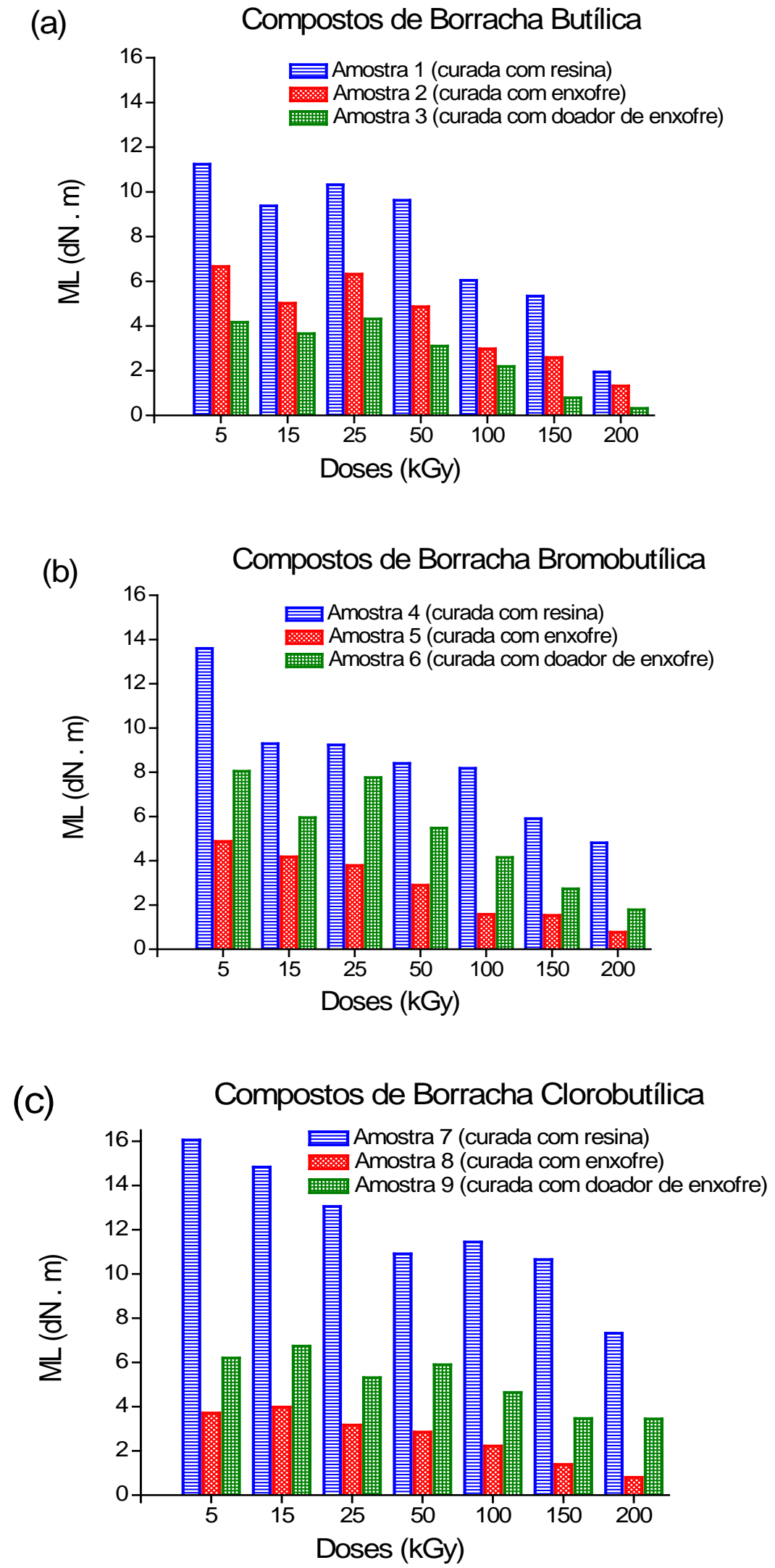

FIGURA 41: Torque mínimo dos compostos de (a) borracha butílica, (b) borracha bromobutílica e (c) borracha clorobutílica irradiadas e cisalhadas. Curada com resina (azul), enxofre (vermelho) e doador de enxofre (verde). 
O composto de borracha butílica curada com resina (amostra 1) mostrou equilíbrio de valores de torque mínimo, até a dose de 50 kGy. Provavelmente pela ocorrência simultânea de cisão e reticulação, com predomínio da reticulação. Em virtude deste composto apresentar sistema de cura mais lento (característica da cura com resina), que com novo aquecimento causado pelo cisalhamento mecânico, ativou novos pontos de reticulação.

Para doses entre 50 kGy e 200 kGy, houve decréscimo de valores de torque, indicando predominância de cisão de cadeia auxiliada pelas reações de degradação a borracha. As amostras de borracha butílica curada com enxofre e doador de enxofre (amostra 2 e 3), também apresentaram equilíbrio de valores de torque mínimo, até a dose de 50 kGy. Indicando a ocorrência de cisão e reticulação. Para doses entre 100 kGy e 200 kGy observou-se diminuição do torque proporcional a dose, sugerindo elevado índice de degradação, e provável destruição da cadeia molecular em virtude do cisalhamento mecânico.

A amostra 4 (curada com resina) mostrou, em doses baixas (5 kGy), o predomínio da reticulação; provavelmente pela baixa taxa de cura característico desse sistema de vulcanização, e com aquecimento promovido pelo cisalhamento mecânico, ativou os pontos de reticulação. Para doses de 15 kGy e 100 kGy, foi observado um equilíbrio de valores apontando para a ocorrência simultânea de cisão e reticulação. Acima de 100 kGy, observou-se diminuição dos valores de torque, indicando predomínio da cisão de cadeia.

A amostra 5 (curada com enxofre) e amostra 6 (curada com doador de enxofre) também apresentaram valores mais elevados de torque, indicando tendência a reticulação, até a dose de 50 kGy. Sugerindo que a mastigação mecânica promoveu novos pontos de reticulação, provavelmente pela presença de enxofre residual. Para doses superiores a 100 kGy observou-se diminuição do torque mínimo, indicando a predominância da cisão e da degradação oxidativa do polímero.

Os resultados obtidos para os compostos formulados com borracha clorobutílica, amostra 7 (curada com resina), amostra 8 (curada com enxofre) e 
amostra 9 (curada com doador de enxofre) foram similares aos encontrados para as borrachas bromobutílicas, ou seja, aumento de valores de torque até a dose de 50 kGy, sugerindo tendência a reticulação. Para doses entre 100 kGy e 200 kGy, houve diminuição de valores, portanto equilíbrio entre cisão e reticulação.

5.2.5 Diferença entre o torque máximo $(\mathrm{MH})$ e torque mínimo $(\mathrm{ML})$ dos compostos de borrachas butílica e halobutílica não irradiadas, irradiadas e das borrachas irradiadas e cisalhadas.

Os valores de $\Delta \mathrm{M}=(\mathrm{MH}-\mathrm{ML})$ fornecem uma ideia qualitativa da densidade de ligações cruzadas, uma vez que o aumento da diferença entre os torques sugere um aumento do grau de reticulação.

A TAB. 11 mostra os valores obtidos de $\Delta M$ para as amostras de borrachas butílica e halobutílica irradiadas. A TAB. 12 mostra os valores obtidos de $\Delta \mathrm{M}$ para as amostras de borrachas butílicas e halobutílicas irradiadas e cisalhadas.

TABELA 11: Resultado do $\Delta \mathrm{M}$ (dN.m) dos compostos de borrachas butílica, bromobutílica e clorobutílica irradiadas e não irradiadas.

\begin{tabular}{c|c|c|c|c|c|c|c|c|c}
\hline $\begin{array}{c}\text { Amostra } \\
\text { Doses }\end{array}$ & 1 & 2 & 3 & 4 & 5 & 6 & 7 & 8 & 9 \\
\hline $0 \mathrm{kGy}$ & 10,94 & 8,06 & 8,16 & 11,38 & 3,37 & 2,23 & 18,62 & 5,79 & 5,62 \\
\hline $5 \mathrm{kGy}$ & 4,51 & 5,04 & 1,81 & 1,49 & 3,45 & 0,56 & 2,03 & - & 0,23 \\
\hline $15 \mathrm{kGy}$ & 3,15 & - & 1,06 & 2,47 & - & - & 3,12 & - & 0,19 \\
\hline $25 \mathrm{kGy}$ & 4,36 & - & 1,16 & 0,57 & - & - & 0,83 & - & 0,19 \\
\hline $50 \mathrm{kGy}$ & 3,34 & - & 1,06 & 0,76 & - & - & 0,72 & - & - \\
\hline $100 \mathrm{kGy}$ & 2,23 & - & 0,61 & 0,33 & - & - & 0,43 & - & - \\
\hline $150 \mathrm{kGy}$ & 1,63 & - & 0,49 & 0,15 & - & - & 0,77 & - & - \\
\hline $200 \mathrm{kGy}$ & 1,36 & - & 0,36 & 0,12 & - & - & - & - & - \\
\hline
\end{tabular}

amostra 1, 2 e 3 (butílica curada com resina, enxofre e doador de enxofre); amostra 4, 5 e 6 (bromobutílica curada com resina, enxofre e doador de enxofre); amostra 7, 8 e 9 (clorobutílica curada com resina, enxofre e doador de enxofre).

As amostras 1 (butílica curada com resina), 4 (bromobutílica curada com resina) e 7 (clorobutílica curada com resina), apresentaram valores mais elevados de $\Delta \mathrm{M}$ para as amostras sem irradiação. Estes resultados podem estar associados à lenta formação de ligações cruzadas típicas desse sistema de cura, 
que exige elevadas temperaturas para serem ativadas $\left(180^{\circ} \mathrm{C}\right.$ a $\left.190^{\circ} \mathrm{C}\right)$. Após a irradiação, observou-se decréscimo de valores, proporcional à dose aplicada indicando diminuição da densidade de reticulação, possivelmente em função de intensa cisão de cadeia. Os valores ausentes estão abaixo da sensibilidade do equipamento.

As amostras 2, 5 e 8 (butílica curada com enxofre, bromobutílica curada com enxofre e clorobutílica curada com enxofre), e as amostras 3, 6 e 9 (butílica curada com doador de enxofre, bromobutílica curada com doador de enxofre e clorobutílica curada com doador de enxofre). Mostraram tendência à cisão, para doses baixas (5 kGy); para doses acima de 15 kGy domínio de cisão, seguida de elevado grau de degradação, principalmente para as amostras curadas com enxofre, nestas composições existem muitas reações do tipo polissulfídicas, pouco estáveis e suscetíveis ao ataque dos radicais livres formados durante a cisão de cadeia. Os valores de $\Delta M$ decrescem em virtude da degradação do material, pois o torque requerido para oscilar o rotor do reômetro é quase nulo em razão da baixa densidade de reticulação.

TABELA 12: Resultado do $\Delta \mathrm{M}$ (dN.m) dos compostos de borrachas butílica, bromobutílica e clorobutílica irradiadas e cisalhadas.

\begin{tabular}{c|c|c|c|c|c|c|c|c|c}
\hline $\begin{array}{c}\text { Amostra } \\
\text { Doses }\end{array}$ & 1 & 2 & 3 & 4 & 5 & 6 & 7 & 8 & 9 \\
\hline $0 \mathrm{kGy}$ & 10,94 & 8,06 & 8,16 & 11,38 & 3,37 & 2,23 & 18,62 & 5,79 & 5,62 \\
\hline $5 \mathrm{kGy}$ & 1,40 & 0,78 & 1,58 & - & 0,21 & $0,42-$ & 0,31 & 0,92 & 0,16 \\
\hline $15 \mathrm{kGy}$ & 1,58 & 1,11 & 1,63 & - & - & - & - & 0,33 & 0,32 \\
\hline $25 \mathrm{kGy}$ & 1,90 & - & 1,11 & - & - & - & - & 0,56 & 0,36 \\
\hline $50 \mathrm{kGy}$ & 1,34 & - & 1,11 & - & - & - & - & - & - \\
\hline $100 \mathrm{kGy}$ & 1,04 & - & 0,44 & - & - & - & - & - & - \\
\hline $150 \mathrm{kGy}$ & 1,03 & - & 0,52 & - & - & - & - & - & - \\
\hline $200 \mathrm{kGy}$ & 1,24 & - & 0,38 & - & - & - & - & - & - \\
\hline
\end{tabular}

Amostra 1, 2 e 3 (butílica curada com resina, enxofre e doador de enxofre);

amostra 4, 5 e 6 (bromobutílica curada com resina, enxofre e doador de enxofre);

amostra 7, 8 e 9 (clorobutílica curada com resina, enxofre e doador de enxofre).

A TAB.12 mostra o resultado de $\Delta \mathrm{M}$ para todas as amostras de borrachas butílicas, bromobutílicas e clorobutílicas (1, 4 e 7 curadas com resina, 2, 5 e 8 curadas com enxofre e 7, 8 e 9 curadas com doador de enxofre); 
irradiadas e cisalhadas. Observa-se que os resultados encontrados foram os mostrados para as amostras irradiadas, ou seja, todos os resultados apresentaram queda abrupta de valores de $\Delta \mathrm{M}$ depois da irradiação $\mathrm{e}$ cisalhamento. Observado elevado grau de cisão de cadeia e degradação oxidativa.

\subsection{Propriedade Dinâmico Mecânico - (DMA)}

Na FIG.42 estão apresentados os resultados de tan $\delta$, em função da temperatura, para amostra 2 (borracha butílica curada com enxofre) irradiada e não irradiada nas doses de 25 kGy, 50 kGy, 100 kGy, 150 kGy e 200 kGy. Todas as curvas de $\tan \delta$ apresentaram um pico de relaxamento próximo a $-30^{\circ} \mathrm{C}$, associados com a transição vítrea $(\mathrm{Tg})$.

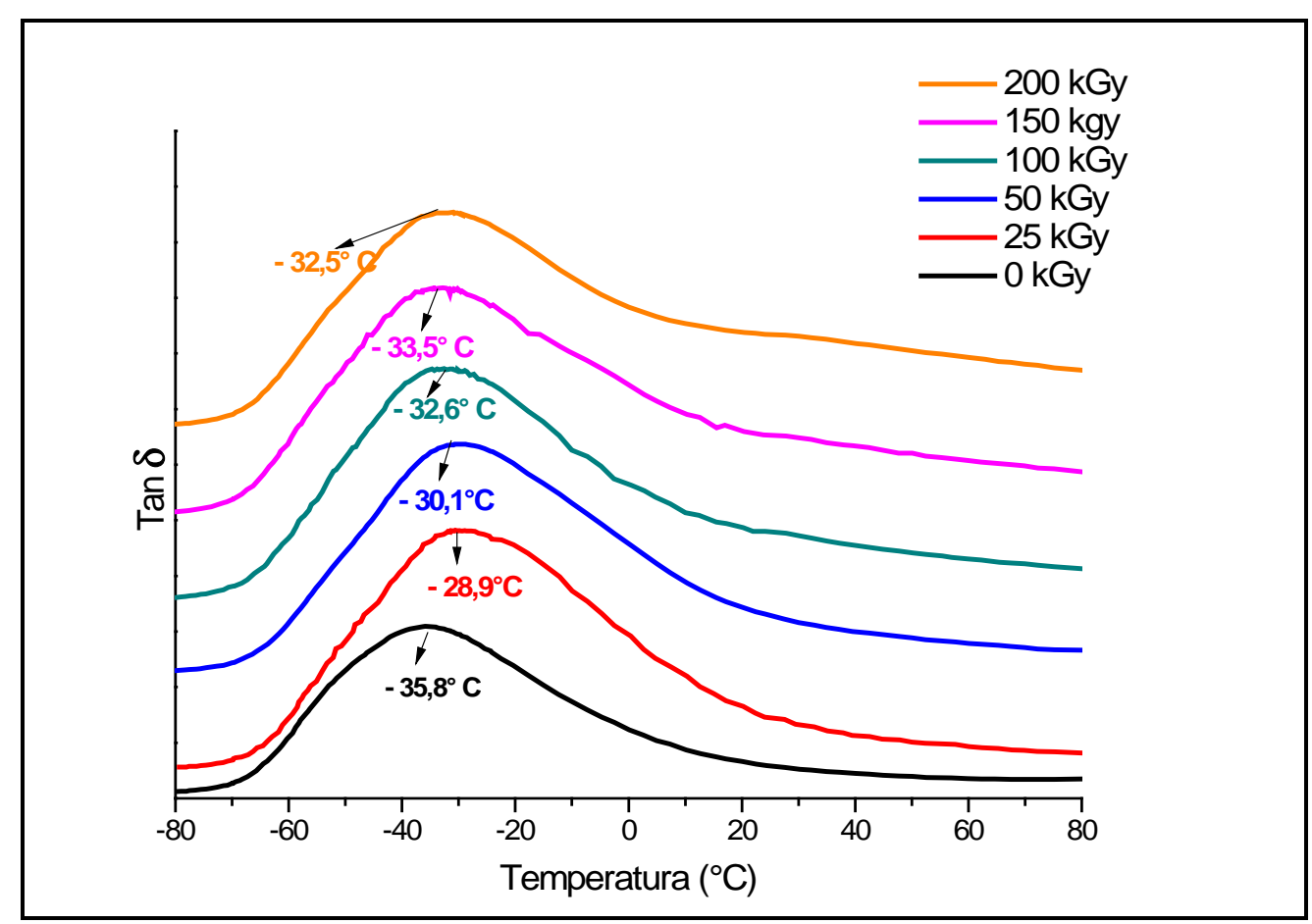

FIGURA 42: Tan $\delta$ da amostra 2 (butílica curada com enxofre) em função da temperatura para as amostras irradiadas e não irradiadas.

Na FIG. 42 pode-se observar aumento da Tg para a dose de 25 kGy, mostrando tendência à reticulação. Para doses entre 50 kGy e 200 kGy observou- 
se diminuição da $\mathrm{Tg}$ indicando a ocorrência de cisão e reticulação, com predominância da cisão de cadeia.

A influência da dose de irradiação sobre estas propriedades mecânicas $E^{\prime}$ (módulo de armazenamento) e tan $\delta$ (E”/E') respectivamente, em função da dose a $-80^{\circ} \mathrm{C}$ é mostrada nas FIG. 43 e Fig. 44.

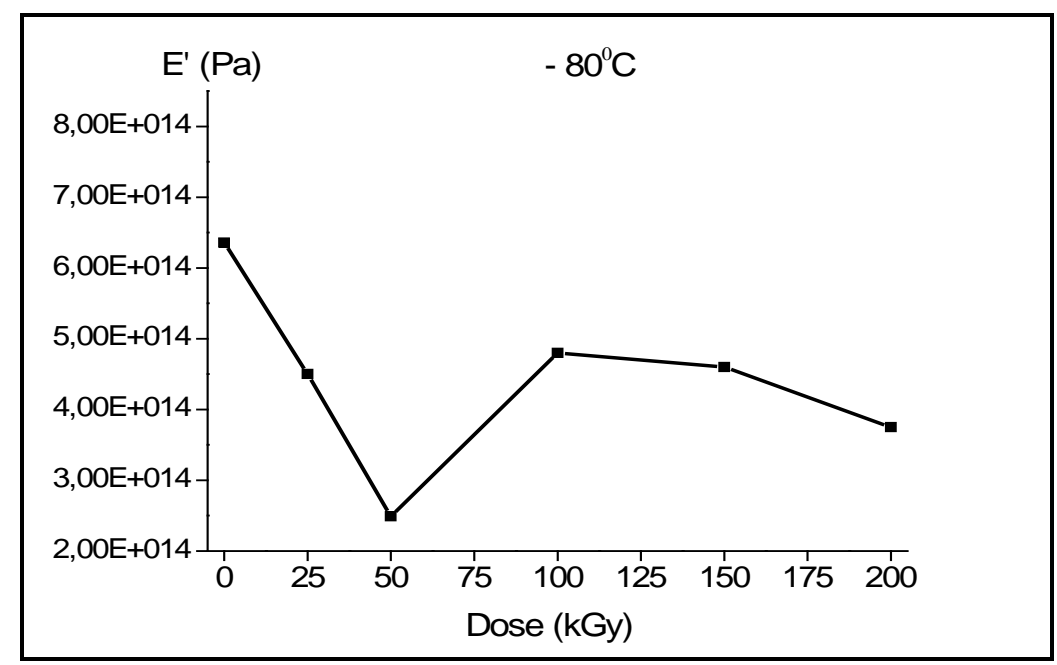

FIGURA 43: Influência da dose de irradiação no módulo de armazenamento (E') da amostra 2 (butílica curada com enxofre) em função da dose na temperatura de $-80^{\circ} \mathrm{C}$ para amostra não irradiada e irradiada.

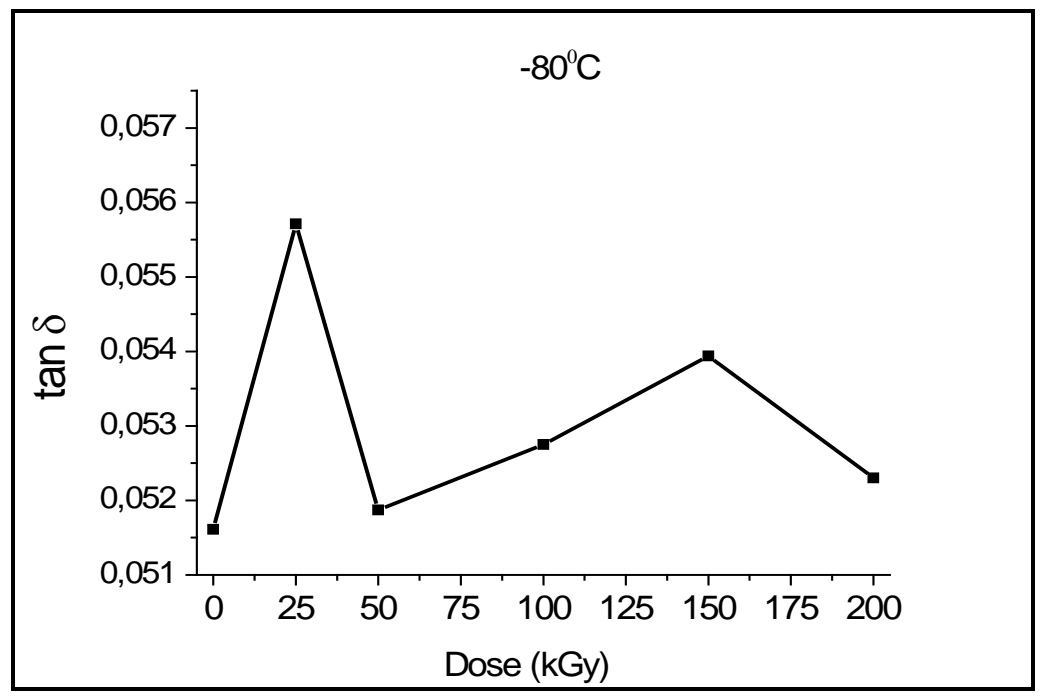

FIGURA 44: Tan $\delta$ da amostra 2 (butílica curada com enxofre) em função da dose na temperatura de $-80^{\circ} \mathrm{C}$ para amostra irradiada e não irradiada. 
Nas FIG. 43 e FIG. 44 pode-se notar que para temperatura menor que a Tg, decréscimo acentuado de E' nas doses ente 0 kGy e 50 kGy, indicando cisão de cadeia. Para doses superiores a 50 kGy oscilação de valores indicando a ocorrência simultânea de cisão e reticulação. Os mesmos resultados são observados para tan $\delta$, verificando-se a oscilação de valores, sugerindo a ocorrência de cisão e reticulação, com predomínio da cisão.

Para a temperatura mais elevada do que a $\mathrm{Tg}, 80^{\circ} \mathrm{C}$, o comportamento de $E^{\prime}$ e tan $\delta$ foi muito diferente, como pode ser observado nas FIG.45 e FIG.46. E' apresentou uma queda inicial em 25 kGy e posteriormente, se manteve constante, enquanto que o aumento da tan $\delta$ é proporcional à dose. Este aumento pode ser associado à cisão da cadeia, que permite a mobilidade e, portanto $E^{\prime}$ diminui.

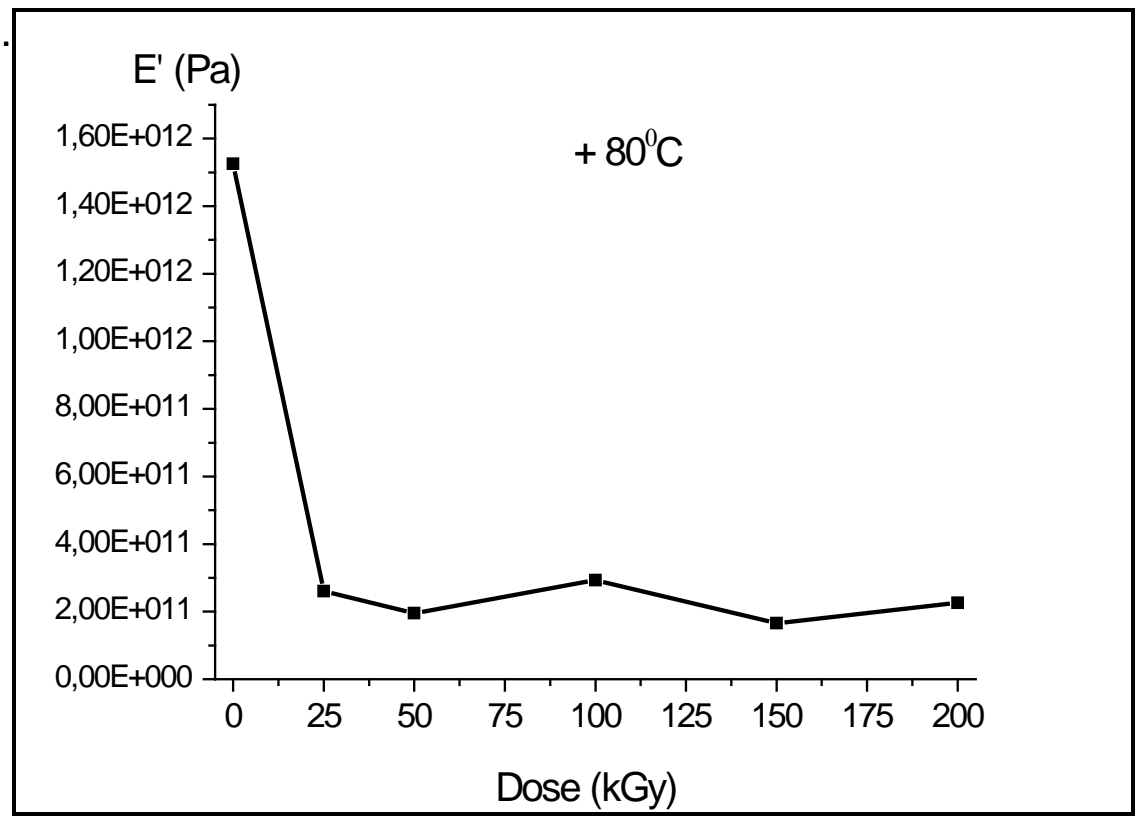

FIGURA 45: Influência da dose de irradiação no módulo de armazenamento (E') da amostra 2 (butílica curada com enxofre) em função da dose na temperatura de $+80^{\circ} \mathrm{C}$ para amostra não irradiada e irradiada. 


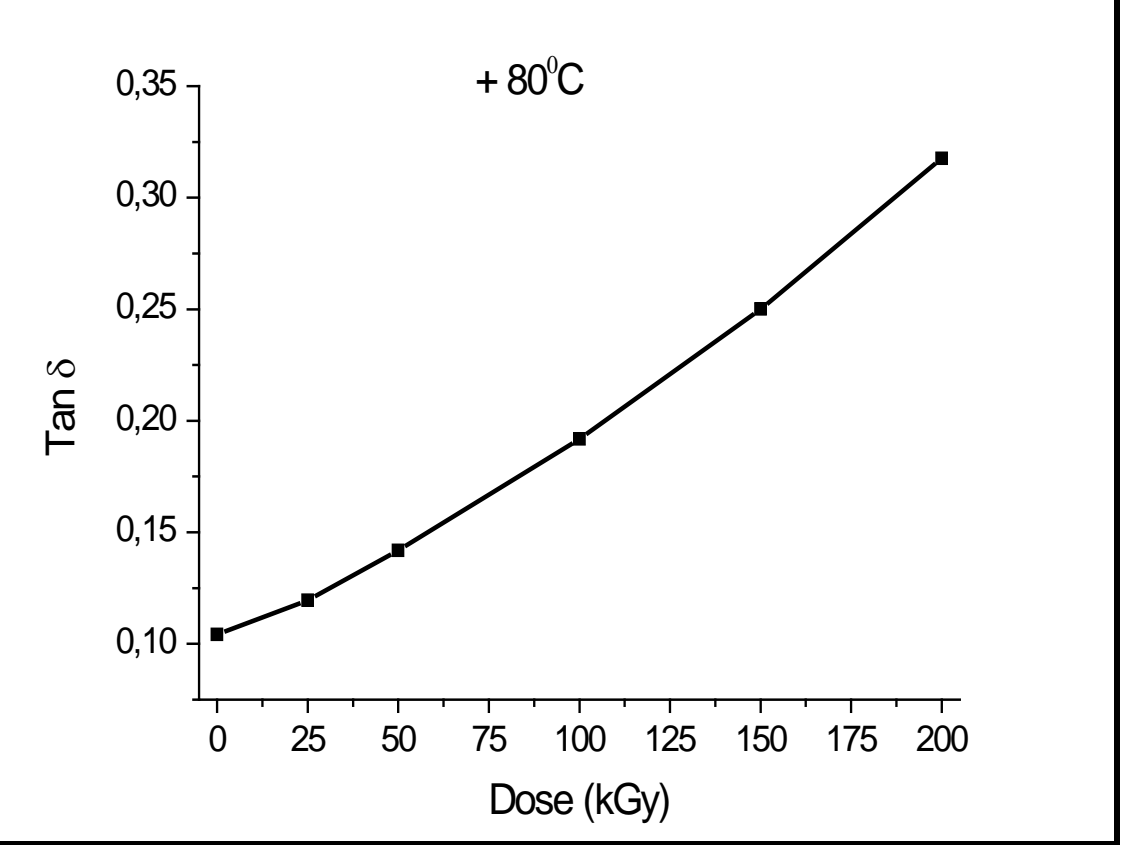

FIGURA 46: Tan $\delta$ da amostra 2 (butílica curada com enxofre) em função da dose na temperatura de $+80^{\circ} \mathrm{C}$ para amostra irradiada e não irradiada.

A Tg (temperatura de transição vítrea) representa a temperatura no qual as móleculas da fase amorfa adquirem maior mobilidade em função do aumento do volume livre. Assim, as curvas mostradas nas FIG. 47 e FIG. 48 confirmam os resultados anteriores, ou seja, os valores de $\tan \delta$ aumentaram consideravelmente enquanto que os valores de E' diminuem abruptamente após a dose de 25 kGy, em consequência da cisão de cadeia. Para as doses mais elevadas estes valores mostraram pequenas mudanças indicando a ocorrência simultânea de cisão e reticulação e degradação oxidativa. 


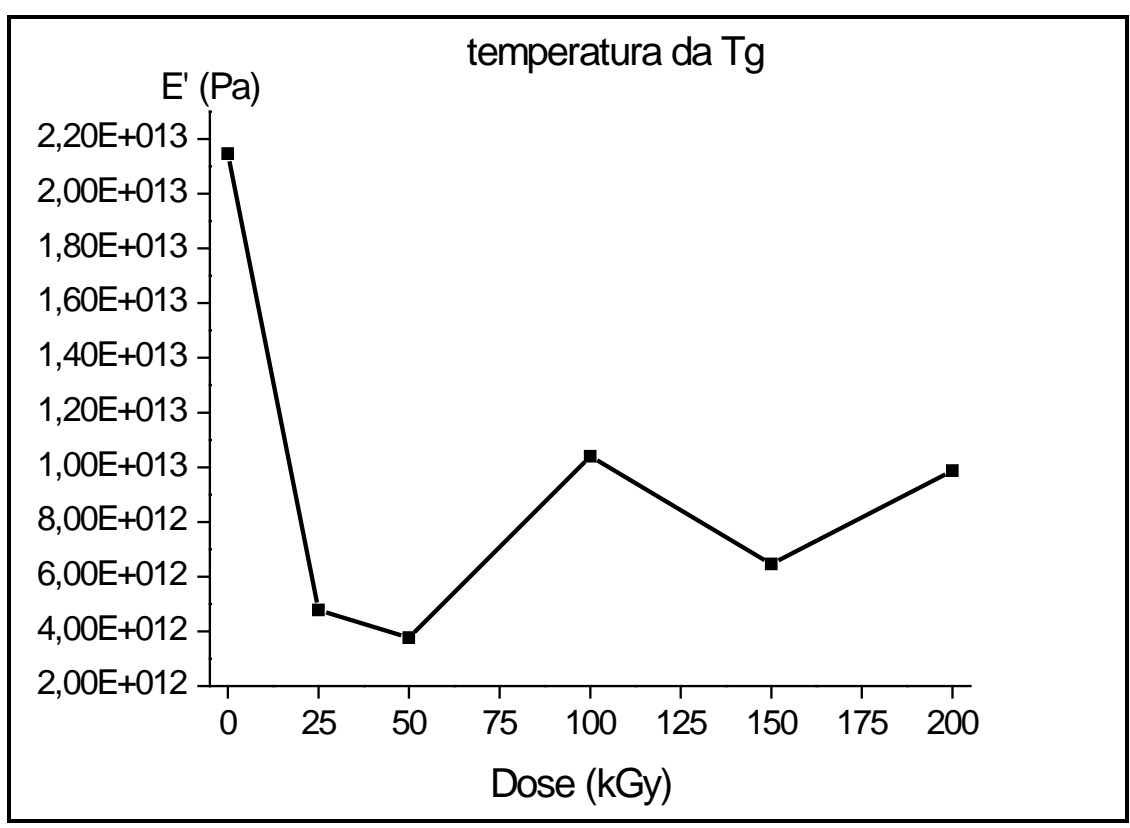

FIGURA 47: Influência da dose de irradiação no módulo de armazenamento (E') da amostra 2 (butílica curada com enxofre) em função da dose na temperatura de transição vítrea (Tg) para amostra não irradiada e irradiada.

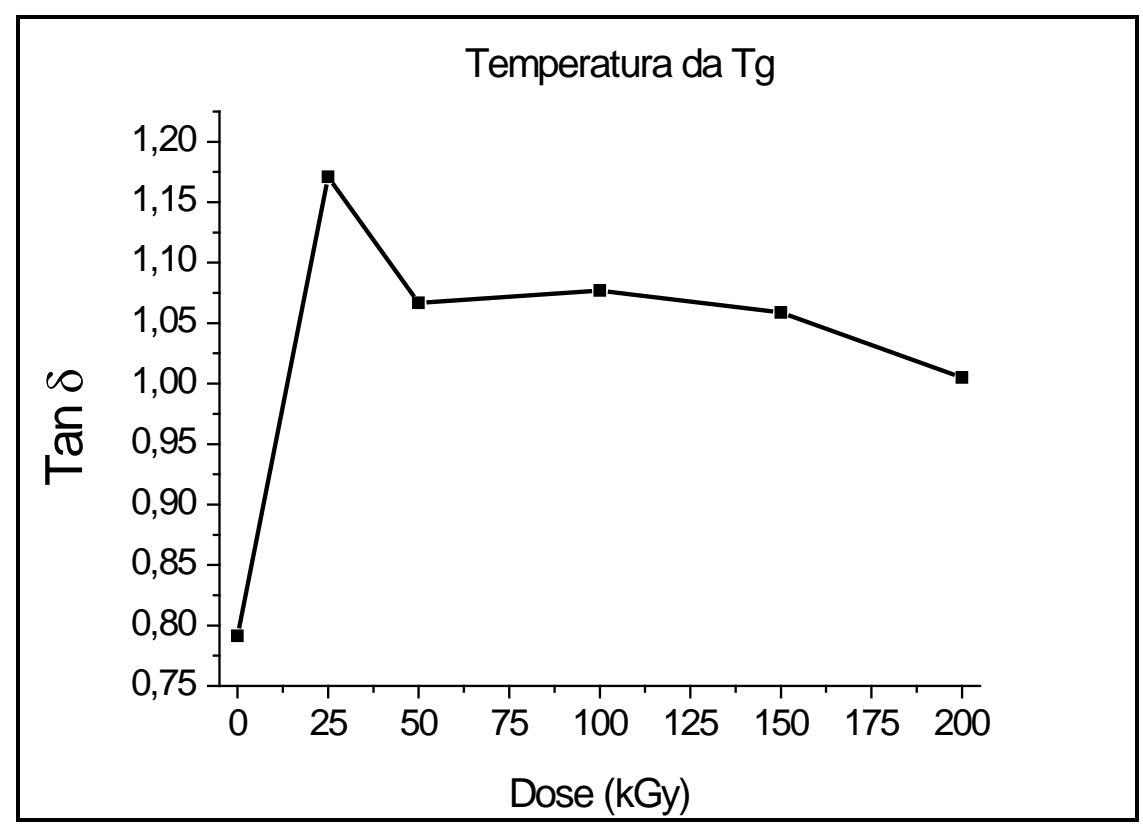

FIGURA 48: Tan $\delta$ da amostra 2 (butílica curada com enxofre) em função da dose na temperatura de Tg para amostra irradiada e não irradiada. 


\subsection{Tensão e Alongamento na Ruptura}

\subsubsection{Tensão e alongamento na ruptura dos compostos de borrachas butílica irradiadas}

Nas FIG. 49 e 50, são apresentados os resultados dos ensaios de tensão e alongamento na ruptura realizada nas formulações de borrachas butílicas curadas com resina, enxofre e doador de enxofre.

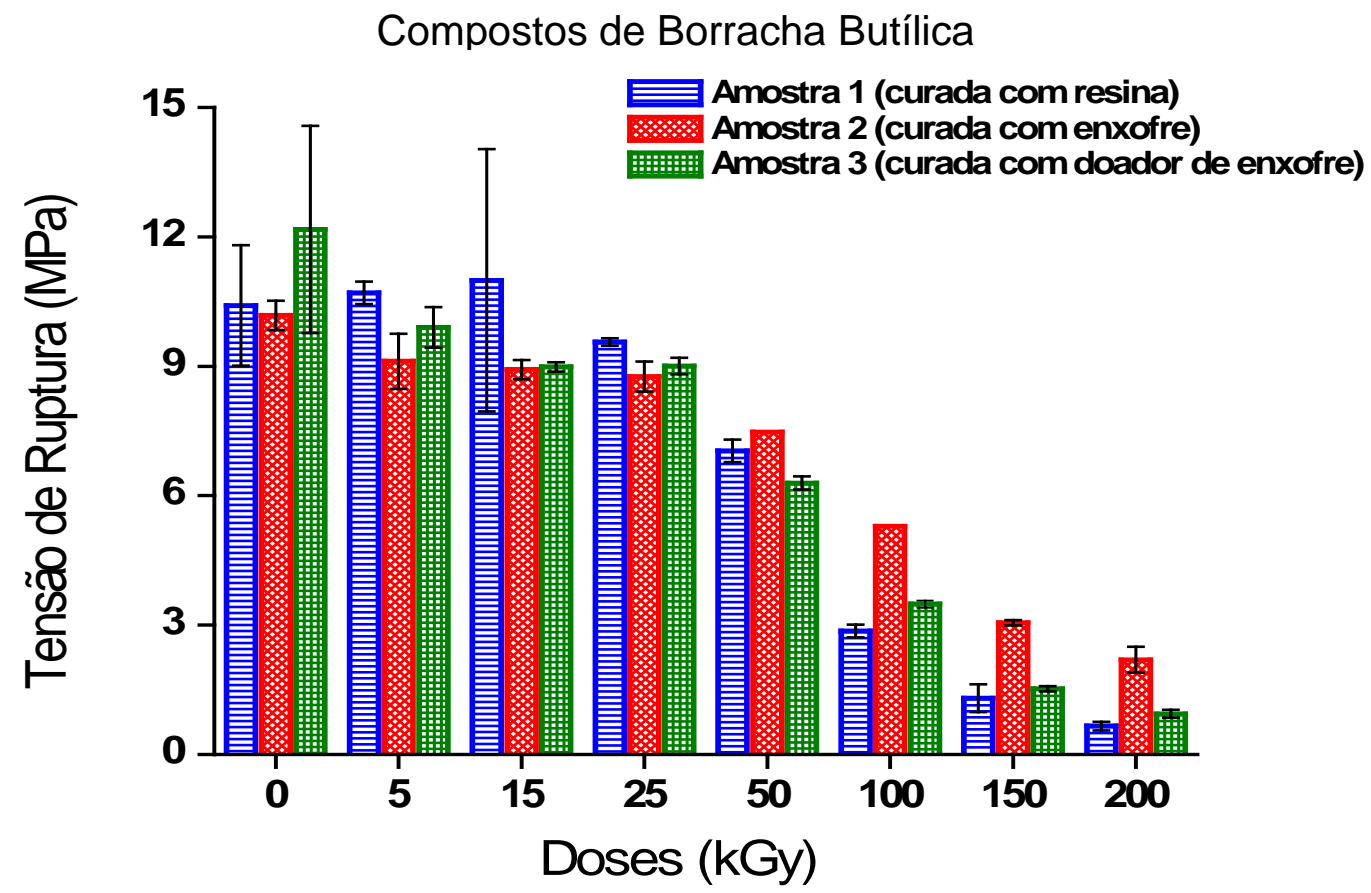

FIGURA 49: Efeito da dose de radiação na tensão de ruptura dos compostos de borracha butílica curada com resina (azul), enxofre (vermelho) e doador de enxofre (verde), irradiados e não irradiados 


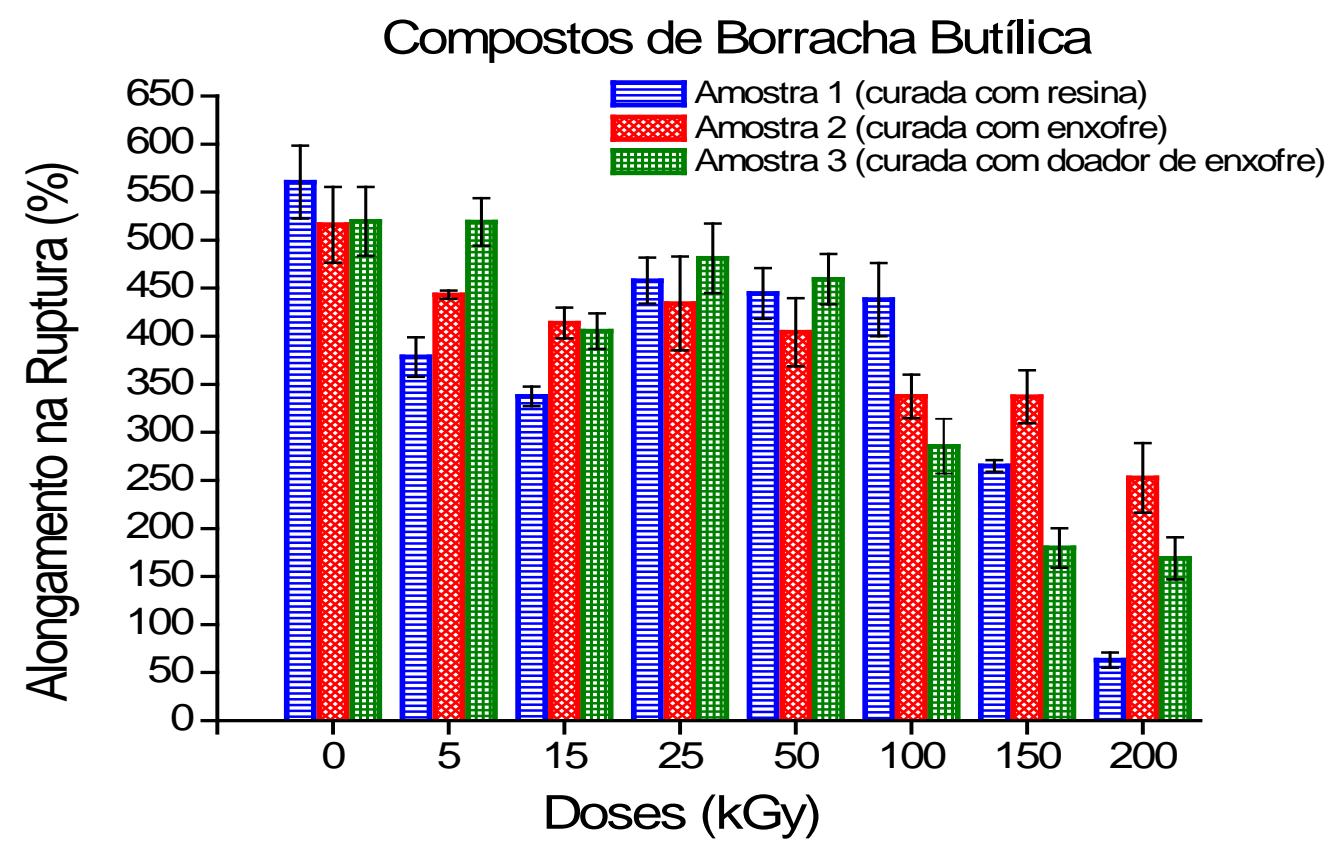

FIGURA 50: Efeito da dose de radiação no alongamento na ruptura dos compostos de borracha butílica curada com resina (azul), enxofre (vermelho) e doador de enxofre (verde), irradiados e não irradiados

Os resultados de tração e alongamento na ruptura da amostra 1 (borracha butílica curada com resina), amostra 2 (borracha butílica curada com enxofre) e amostra 3 (borracha butílica curada com doador de enxofre). Mostraram que, para doses baixas até $25 \mathrm{kGy}$, verifica-se a equivalência de valores de tensão, e também, do alongamento na ruptura, que os efeitos degradativos não foram suficientes para alterar as propriedades. Para doses de 25 kGy e 50kGy, se observa decréscimo na tensão de ruptura e equilíbrio de valores no alongamento na ruptura, provavelmente pela competição entre cisão e reticulação, com o número de reticulações compensando a cisão de cadeia. Já para doses entre 100 kGy e 200 kGy observou-se a predominância da cisão de cadeia, uma vez que cadeias moleculares menores possuem forças intermoleculares mais fracas que não resistem à tração. 


\subsubsection{Tensão e alongamento na ruptura dos compostode borrachas halobutílica irradiadas}

As FIG. 51 e 52 apresentam os resultados dos ensaios de tensão e alongamento na ruptura das formulações de borrachas bromobutílicas curadas com resina, enxofre e doador de enxofre.

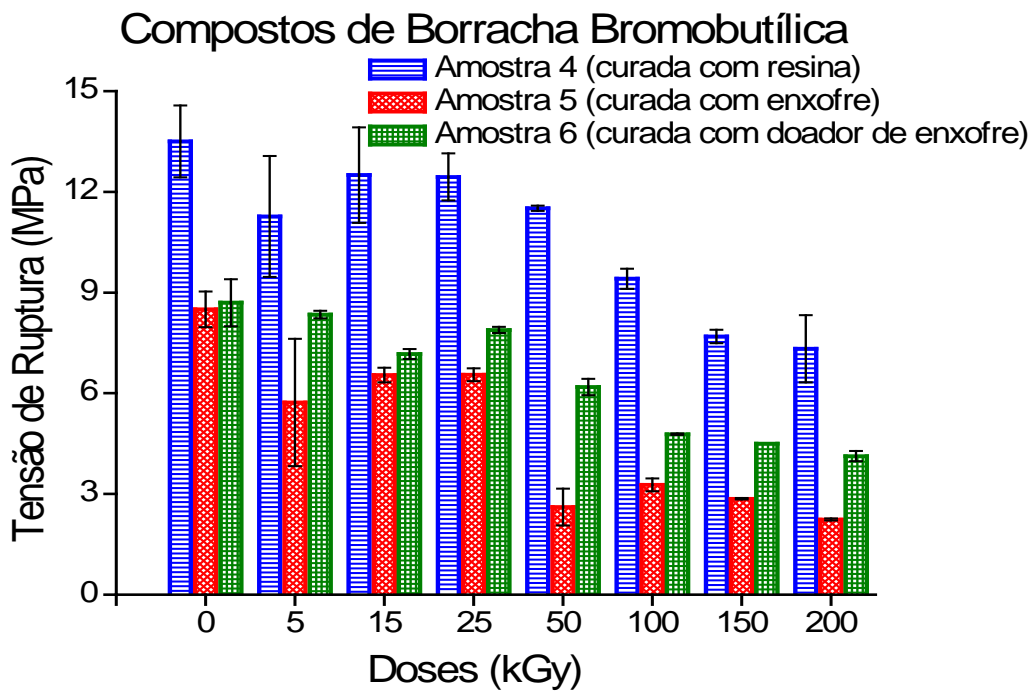

FIGURA 51: Efeito da dose de radiação na tensão de ruptura dos compostos de borracha bromobutílica curada com resina (azul), enxofre (vermelho) e doador de enxofre (verde), irradiados e não irradiados.

Compostos de Borracha Bromobutílica

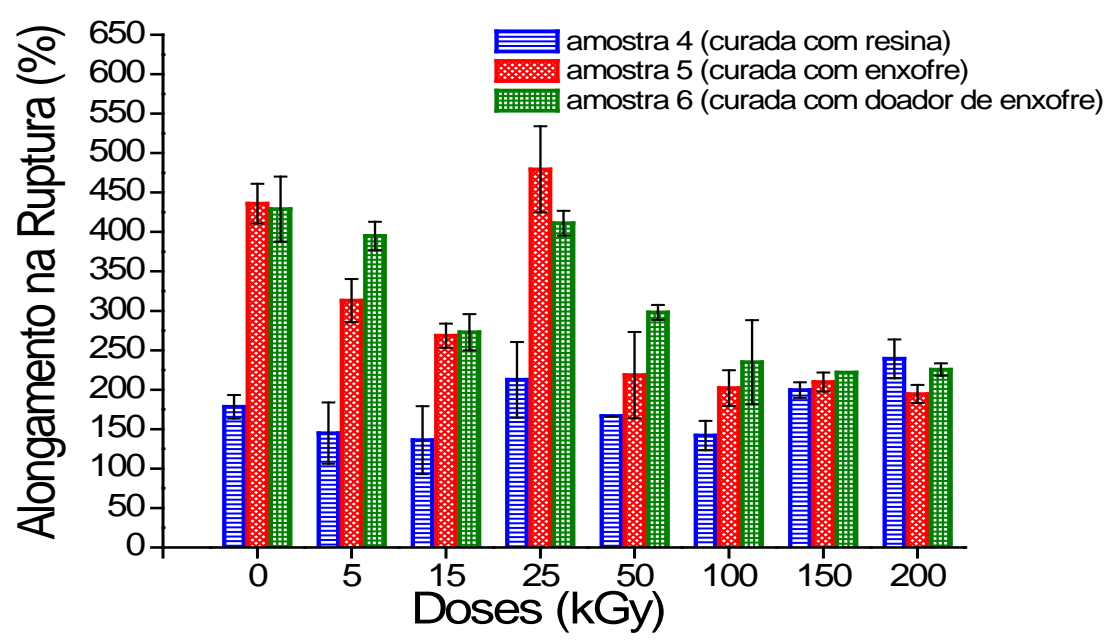

FIGURA 52: Efeito da dose de radiação no alongamento na ruptura dos compostos de borracha bromobutílica curada com resina (azul), enxofre (vermelho) e doador de enxofre (verde), irradiados e não irradiados. 
Os resultados de tensão e alongamento na ruptura dos compostos de borrachas clorobutílicas curadas com resina, enxofre e doador de enxofre são mostrados nas FIG. 53 e 54.

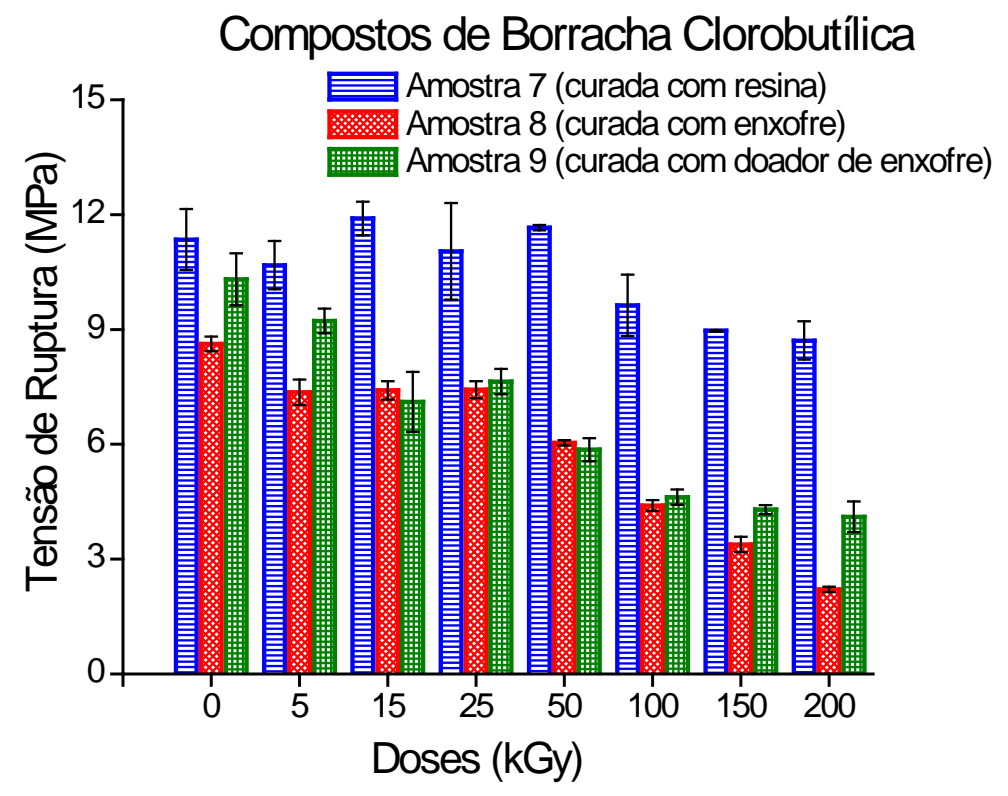

FIGURA 53: Efeito da dose de radiação na tensão de ruptura dos compostos de borracha clorobutílica curada com resina (azul), enxofre (vermelho) e doador de enxofre (verde), irradiados e não irradiados.

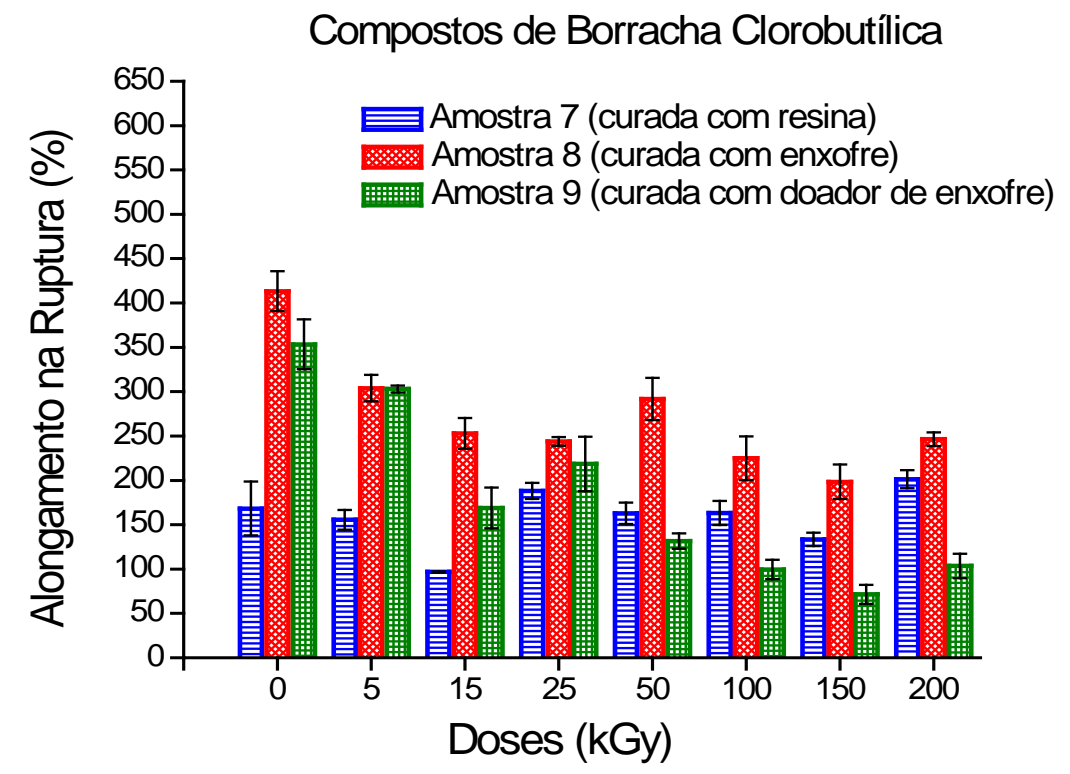

FIGURA 54: Efeito da dose de radiação no alongamento na ruptura dos compostos de borracha clorobutílica curada com resina (azul), enxofre (vermelho) e doador de enxofre (verde), irradiados e não irradiados. 
Para os compostos bromobutílicos e clorobutílicos curados com resina (amostra 4 e 7, respectivamente) observou-se que para as doses entre 5kGy e 50 kGy, os valores de tensão na ruptura são praticamente equivalentes. Assim como o alongamento na ruptura indicando a ocorrência simultânea de cisão e reticulação. Para doses superiores a 100 kGy verificou-se a competição entre cisão e reticulação, com tendência a cisão, uma vez que a cura por resina é realizada através de estruturas cíclicas e o aumento da concentração de radicais livres não propicia a formação de novas cadeias cíclicas para formar reticulação.

Os resultados de tensão e alongamento na ruptura das amostras curadas com enxofre e doador de enxofre (bromobutílica: amostras 5 e 6 e clorobutílica: amostras 8 e 9 respectivamente), mostraram manutenção aproximada dos valores das propriedades até a dose de $25 \mathrm{kGy}$. Acima da dose de 50 kGy, verificou-se uma diminuição dos valores de tensão de ruptura, sugerindo predomínio da cisão sobre a reticulação.

\subsubsection{Tensão e alongamento na ruptura dos compostos de borracha butílica irradiados e cisalhados}

Os resultados de tensão e alongamento na ruptura dos compostos das borrachas butílicas curadas com resina, enxofre e doador de enxofre, que foram irradiadas e cisalhadas estão mostrados nas FIG. 55 e 56 respectivamente. 


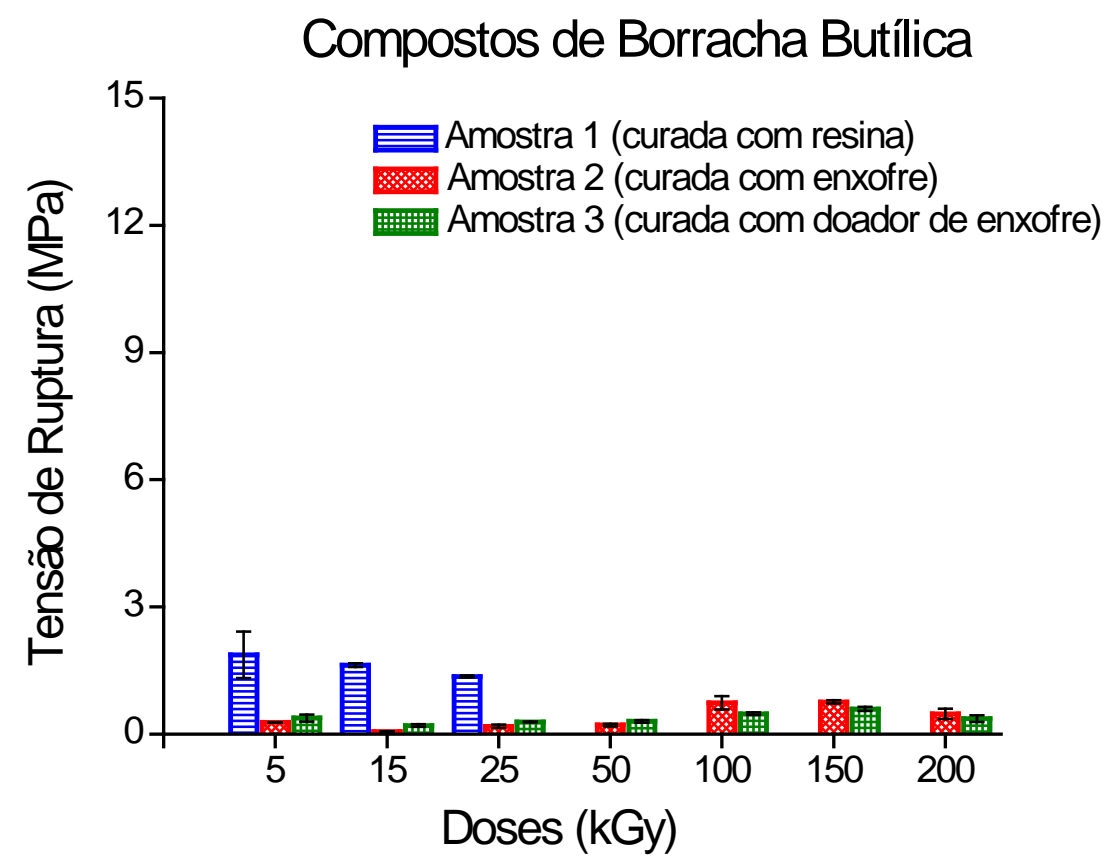

FIGURA 55: Efeito da dose de radiação e do cisalhamento na tensão de ruptura dos compostos de borracha butílica curada com resina (azul), enxofre (vermelho) e doador de enxofre (verde).

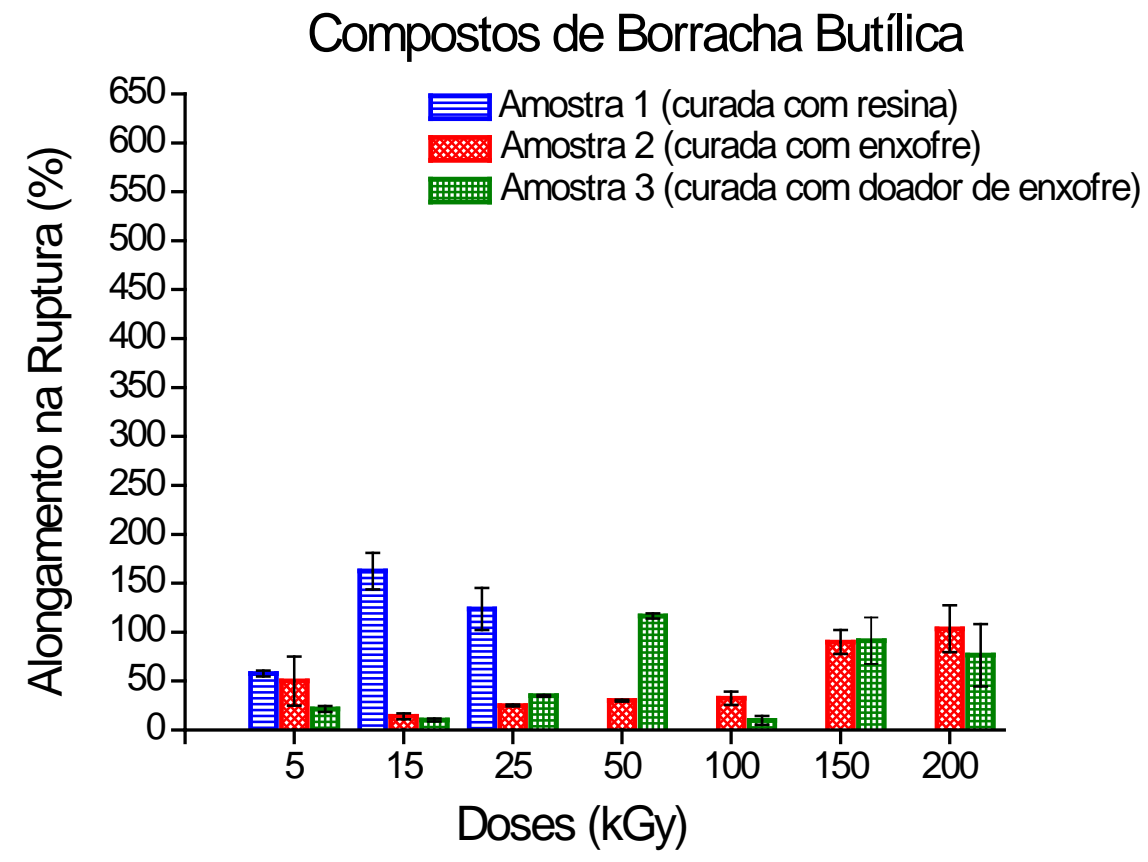

FIGURA 56: Efeito da dose de radiação seguida de cisalhamento no alongamento na ruptura dos compostos de borracha butílica curada com resina (azul), enxofre (vermelho) e doador de enxofre (verde). 
As análises de tensão e alongamento na ruptura do composto curado com resina (amostra 1) mostraram que mesmo em baixas doses houve tendência à elevada cisão de cadeia. Para doses entre 15 kGy e 25 kGy, observou-se a cisão de cadeia e reticulação e para doses superiores a 50 kGy a completa destruição da cadeia polimérica. Sugerindo que, a cisão de cadeia causada pela irradiação e também a cisão causada por degradação oxidativa é intensificada pela mastigação mecânica (cisalhamento), destruindo a integridade das amostras.

Para as amostras 2 e 3 (borracha butílica curada com enxofre e doador de enxofre, respectivamente), verificou-se que para as doses de até $50 \mathrm{kGy}$, houve uma queda acentuada de propriedade, sugerindo predomínio da cisão de cadeia intensificada pelo cisalhamento mecânico. Para doses entre 100 kGy e 200 kGy observou-se aumento dos valores de tração e alongamento na ruptura, sugerindo a formação de novos pontos de reticulações, provavelmente em consequência da presença de enxofre residual nestes compostos, que com o aumento da temperatura gerada pelo cisalhamento, formam novas ligações cruzadas. Observou-se que o cisalhamento mecânico auxilia a degradação da borracha. Pode-se explicar a ampla degradação não somente pela cisão induzida por radiação e pelo cisalhamento, mas também pelas reações de degradação oxidativa.

\subsubsection{Tensão e alongamento na ruptura dos compostos de borrachas halobutílica irradiadas e cisalhadas}

Os resultados de tensão e alongamento na ruptura das formulações de borrachas halobutílicas, curadas com resina, enxofre e doador de enxofre, irradiadas e cisalhadas. Estão apresentados nas FIG. 57 e 58 para os compostos bromobutílicos, e nas FIG. 59 e 60 para os compostos clorobutílicos. 


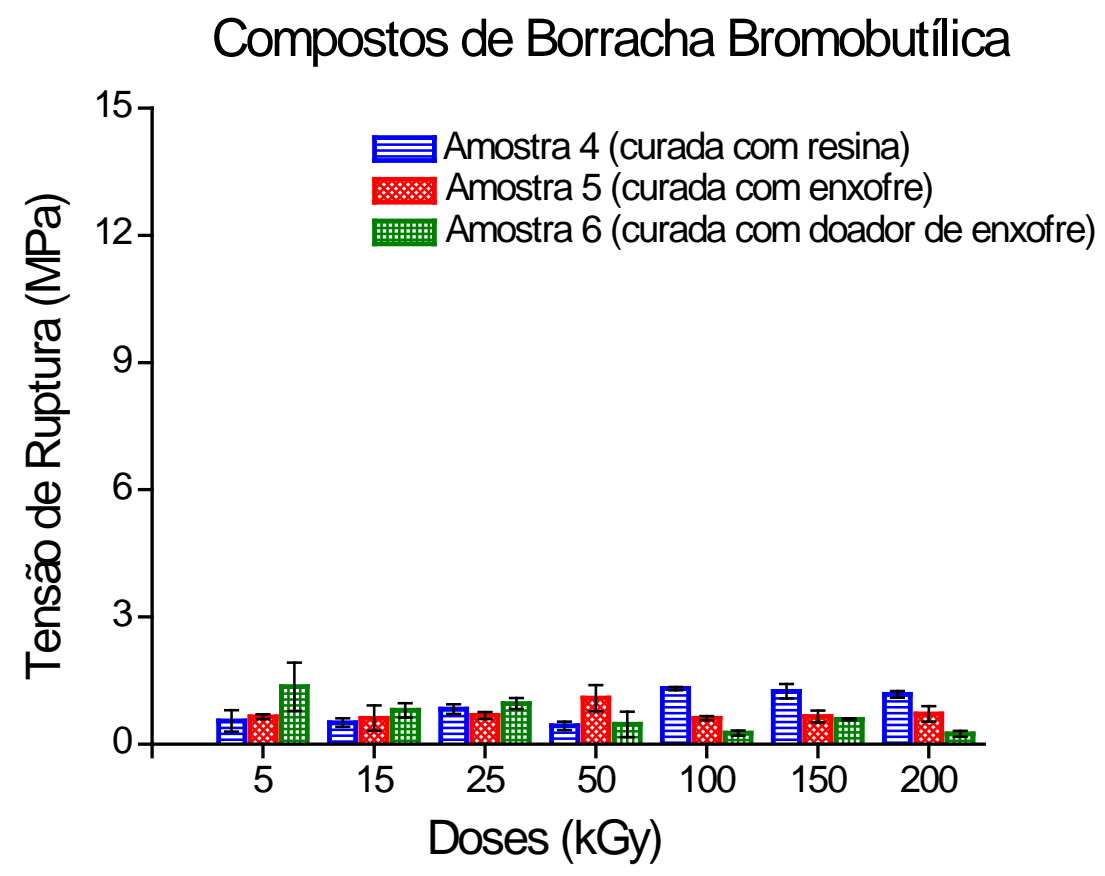

FIGURA 57: Efeito da dose de radiação e cisalhamento na tensão de ruptura dos compostos de borracha bromobutílica curada com resina (azul), enxofre (vermelho) e doador de enxofre (verde).

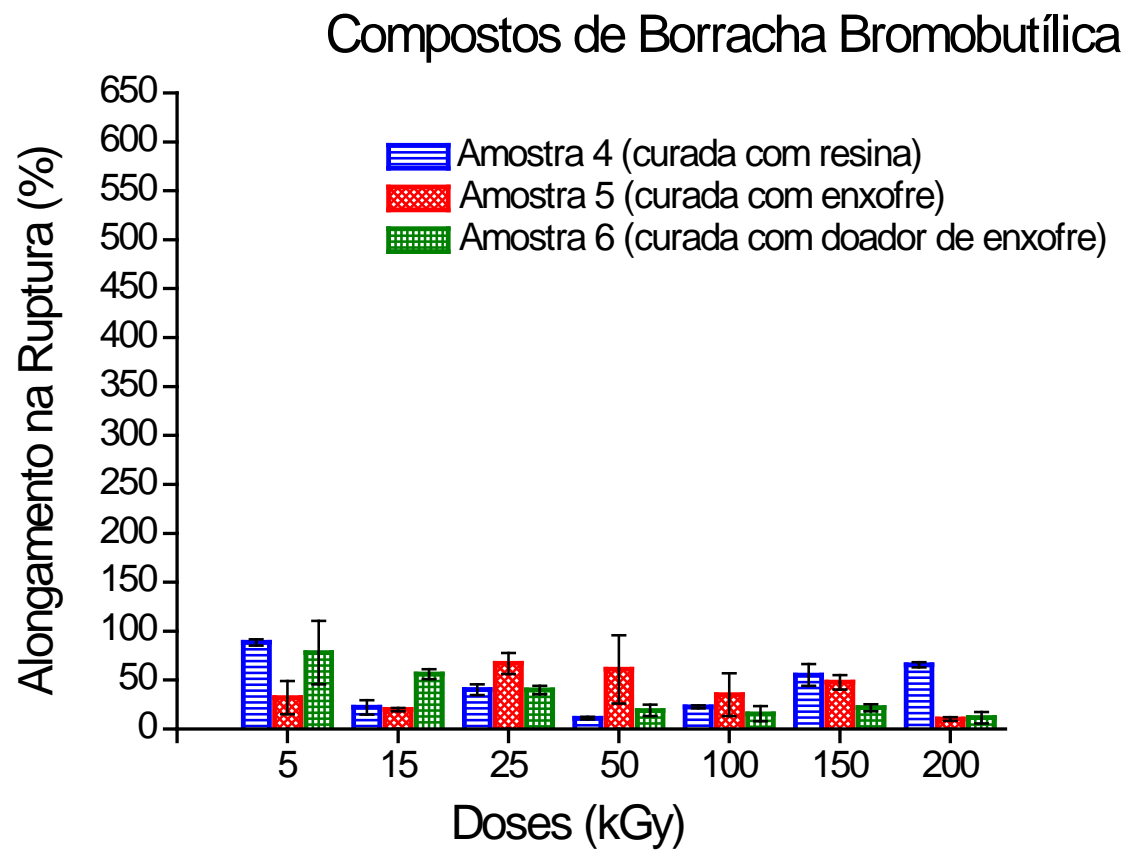

FIGURA 58: Efeito da dose de radiação seguida de cisalhamento no alongamento na ruptura dos compostos de borracha bromobutílica curada com resina (azul), enxofre (vermelho) e doador de enxofre (verde). 


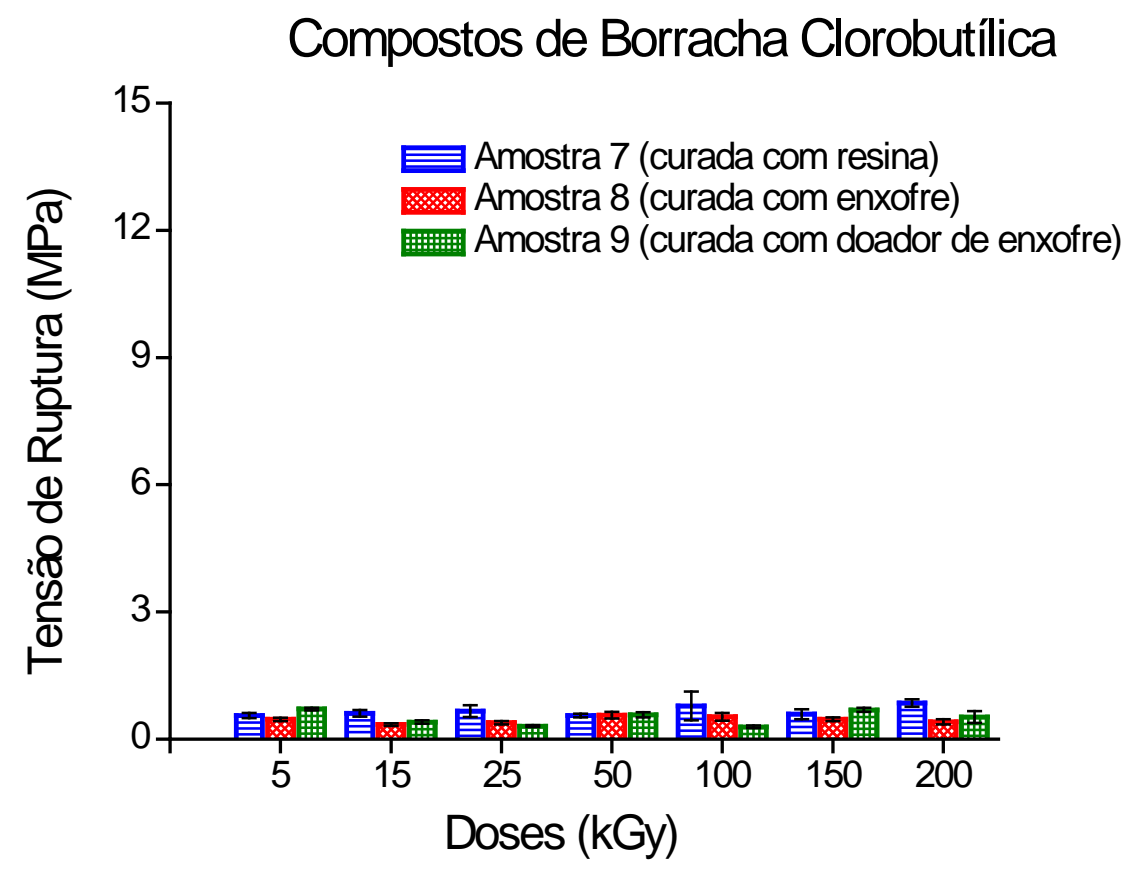

FIGURA 59: Efeito da dose de radiação e cisalhamento na tensão de ruptura dos compostos de borracha clorobutílica curada com resina (azul), enxofre (vermelho) e doador de enxofre (verde).

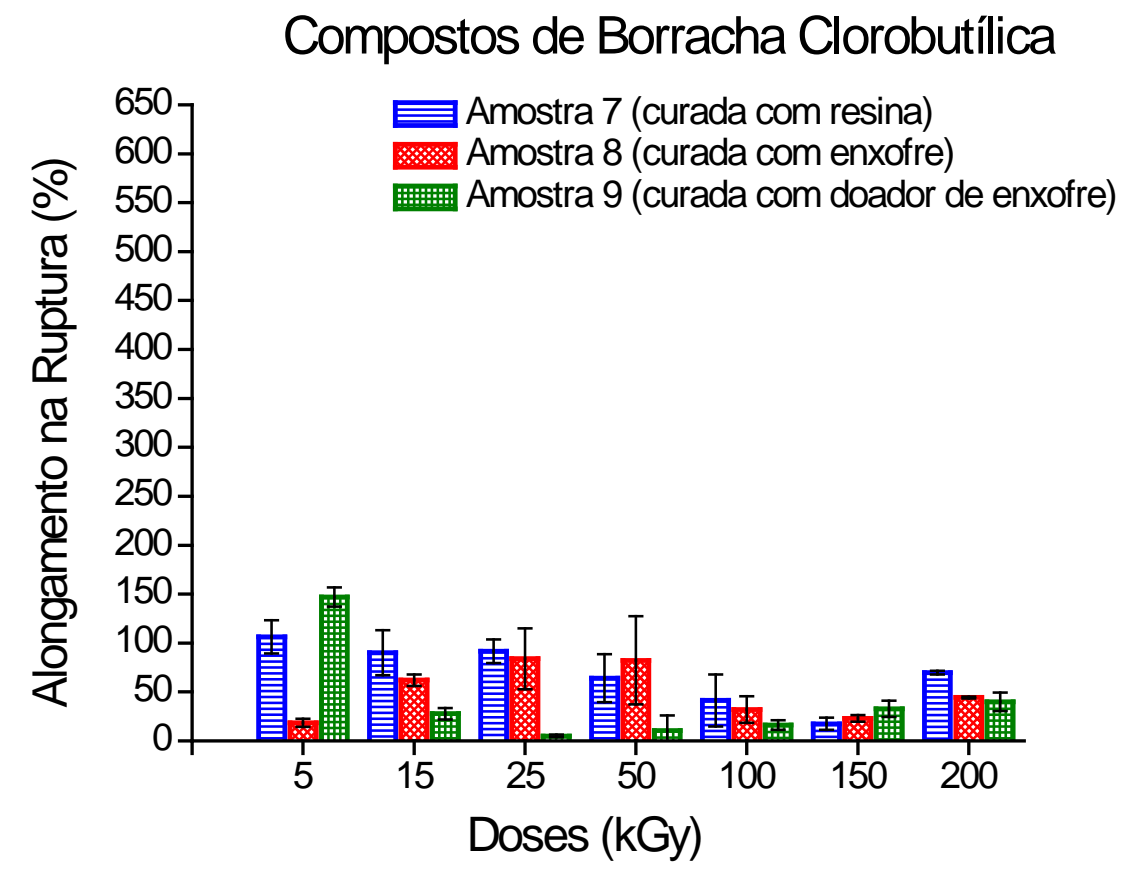

FIGURA 60: Efeito da dose de radiação seguida de cisalhamento no alongamento na ruptura dos compostos de borracha clorobutílica curada com resina (azul), enxofre (vermelho) e doador de enxofre (verde). 
As amostras 4, 5 e 6 (bromobutílica curada com resina, enxofre e doador de enxofre) e as amostras 7, 8 e 9 (clorobutílica curada com resina, enxofre e doador de enxofre), irradiadas e cisalhadas, apresentaram decréscimo acentuado de valores de tensão e alongamento na ruptura já para a dose de 5 kGy indicando aumento da cisão em consequência do cisalhamento, sugerindo que a mastigação mecânica forneceu energia suficiente para romper ligações

Os resultados das análises de tensão e alongamento na ruptura das amostras de borrachas butílicas, bromobutílicas e clorobutílicas curadas com resina, enxofre e doador de enxofre, irradiadas e cisalhadas mostraram decréscimo de tração e alongamento na ruptura, acentuados quando comparados com os resultados das amostras somente irradiadas, indicando que a degradação da borracha irradiada e posteriormente cisalhada é mais intensa.

As curvas de tensão versus deformação foram obtidas diretamente da máquina de ensaio universal (EMIC). Este equipamento permite registar de forma gráfica algumas dessas curvas tensão-deformação dos compostos de borracha. A FIG. 61 mostra as curvas, de tensão versus deformação das amostras de borracha butílica curada com enxofre (amostra 2), borracha bromobutílica curada com resina (amostra 4) e borracha clorobutílica curada com doador de enxofre (amostra 9) não irradiadas, irradiadas nas doses de 25 kGy e 200 kGy e irradiadas nas doses de 25 kGy e 200 kGy e cisalhadas.

Observou-se que, para compostos de borracha butílica curados com enxofre, borracha bromobutílica curados com resina e borracha clorobutílica curados com doador de enxofre, e irradiados com 25 kGy, as amostras apresentaram deformação elástica e plástica, sugerindo que houve competição entre cisão e reticulação. Para dose de 200 kGy, não se observa praticamente nenhuma deformação indicando aumento da cisão, pois moléculas menores deformam menos e sob a ação de oxigênio tendem a se deteriorar. 
(a) Composto de borracha butílica curada com enxofre

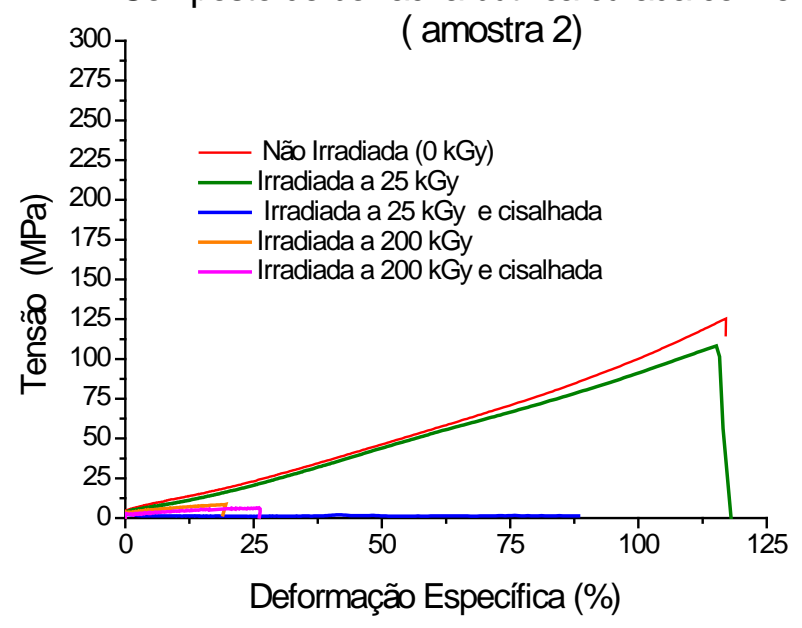

(b) Composto de borracha bromobutílica curada com resinc

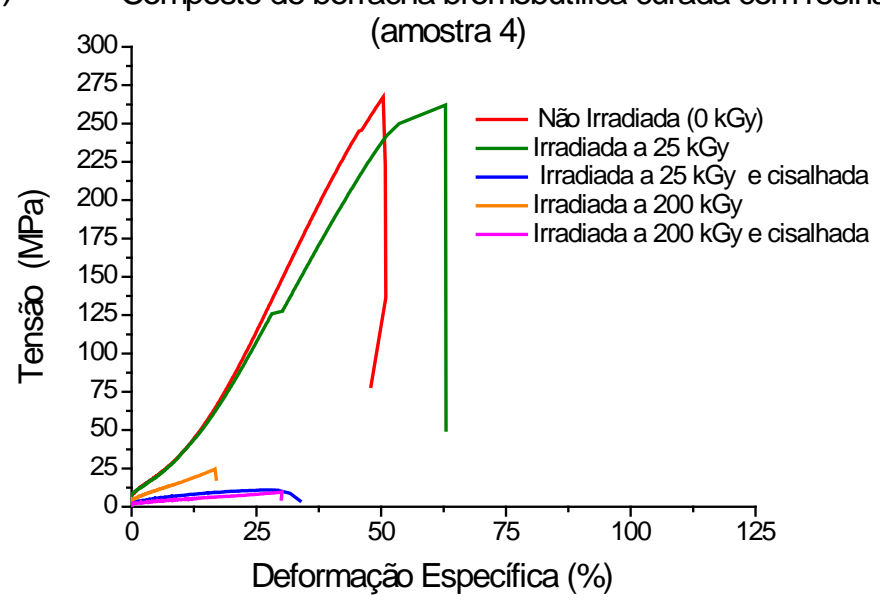

(c) Composto de borracha clorobutilica curada com doador de enxofre

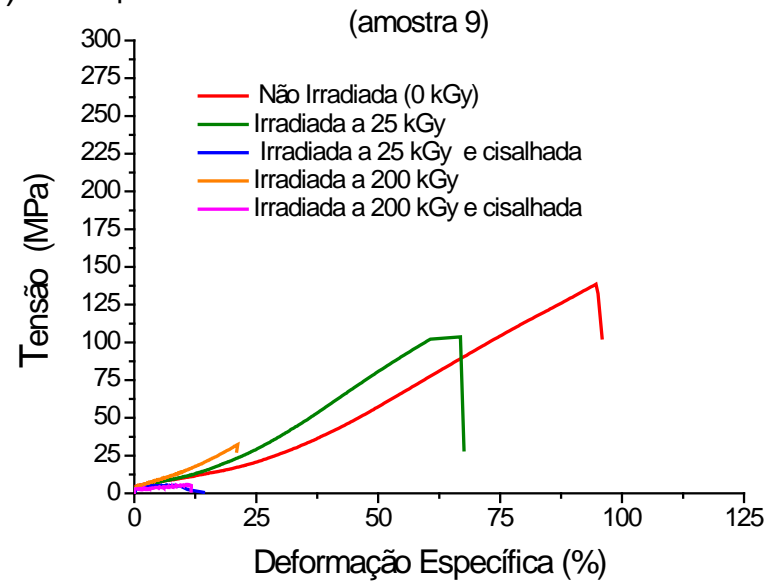

FIGURA 61: Efeito da dose de irradiação e do cisalhamento na deformação da (a) borracha butílica curada com enxofre, (b) borracha bromobutílica curada com resina e (c) borracha clorobutílica curada com doador de enxofre, não irradiadas, irradiadas e irradiadas e cisalhadas. 
Para as amostras irradiadas e cisalhadas, na dose se 25 kGy. Nota-se apenas a deformação plástica, confirmando o aumento da cisão de cadeia em virtude da mastigação mecânica que aumenta a formação de radicais livres, que podem reagir com as moléculas de oxigênio, e promover degradação oxidativa. $\mathrm{Na}$ dose de 200 kGy, se observa a destruição da integridade da amostra em consequência da intensa cisão de cadeia e da degração oxidativa.

\subsubsection{Efeito da irradiação na dureza dos compostos de borrachas butílica e halobutílica irradiadas}

Os efeitos da radiação na dureza dos compostos de borracha butílica, borracha bromobutílica e borracha clorobutílica curadas com resina, enxofre e doador de enxofre, irradiadas e não irradiadas, estão mostrados na FIG. 62.

Observa-se que a amostra 1 (butílica curada com resina) na dose de 15kGy, aumentou levemente o valor de dureza, indicando uma superfície oxidada pela radiação. Para doses entre 25 kGy e 100 kGy verifica-se estabilização de valores de dureza, sugerindo equilíbrio entre cisão e reticulação.

Para os compostos butílicos curados com enxofre e doador de enxofre (amostra 2 e 3), nota-se equilíbrio de valores de dureza para as doses entre 5 kGy e 25 kGy, sugerindo competição entre cisão e reticulação. Para doses superiores a $50 \mathrm{KGy}$ verificou-se ligeiro decréscimo de valores, indicando a aumento da cisão de cadeia e provável degradação oxidativa.

Os compostos de borracha bromobutílica curadas com resina, enxofre e doador de enxofre (amostras 4, 5 e 6), e borracha clorobutílica curados com resina, enxofre e doador de enxofre (amostras 7, 8 e 9) apresentaram similaridade. Para doses baixas entre 5 kGy e 25 kGy, estabilidade de valores indicando competição entre cisão e reticulação em virtude das ligações de hidrogênio que possibilitam a interação intermolecular apesar da intensa cisão de cadeia. 
(a) Compostos de borracha butílica

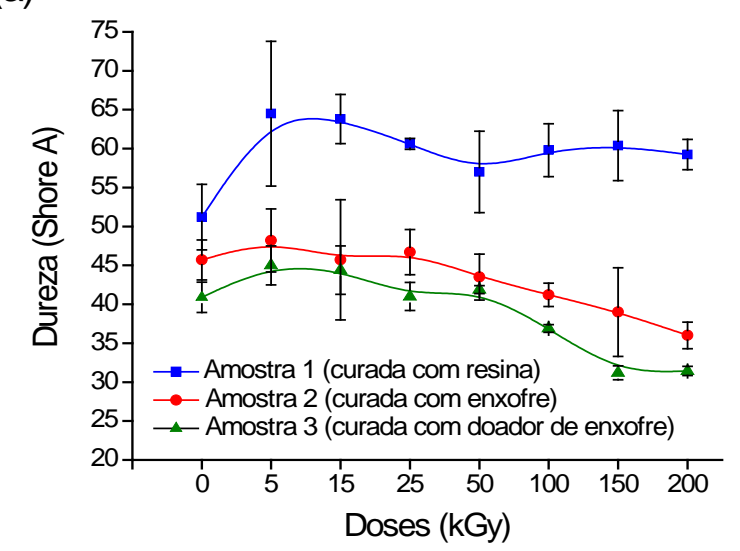

(b)

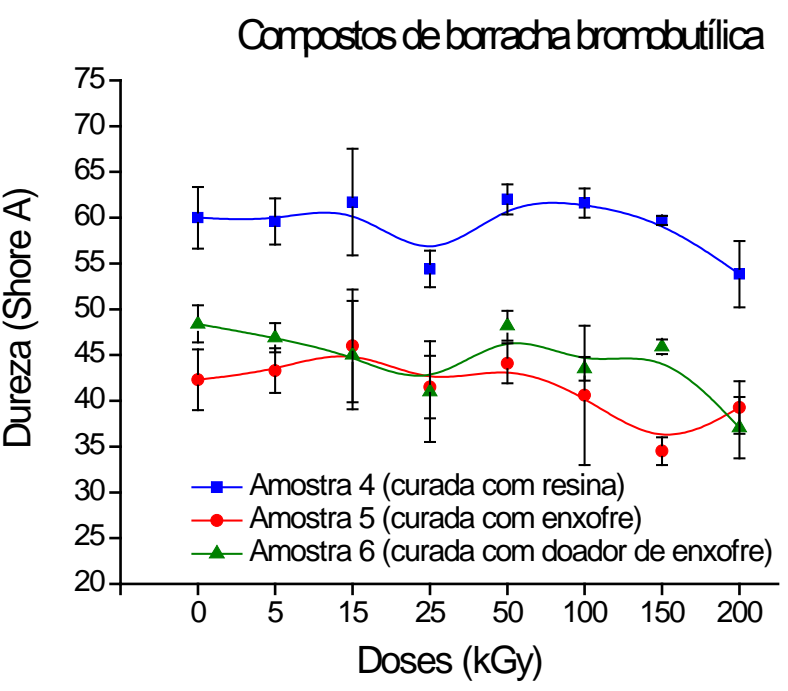

(b)

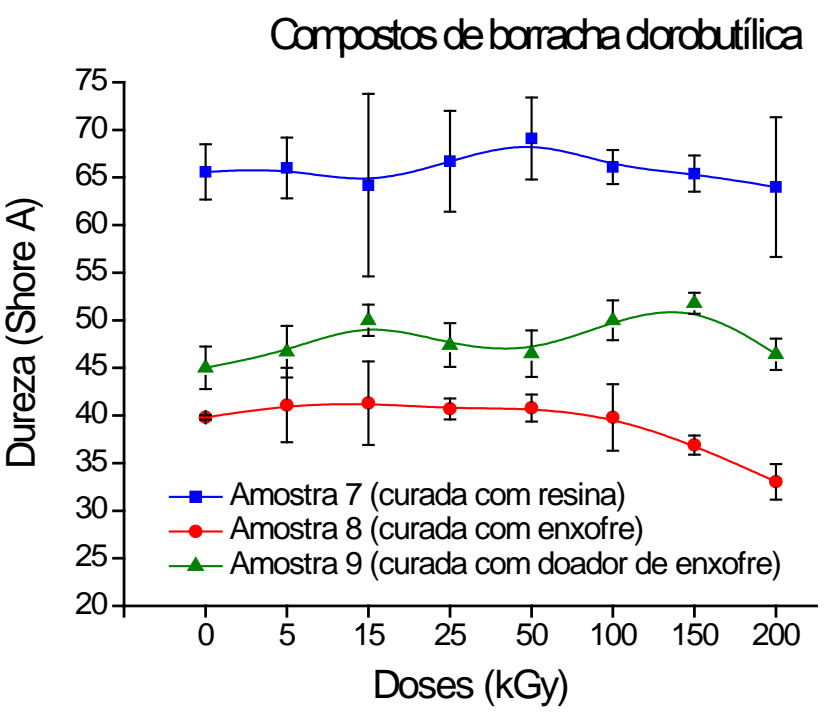

FIGURA 62: Efeito da dose de radiação na dureza dos compostos de borracha (a) butílica, (b) bromobutílica e (c) clorobutílica curados com resina (azul), enxofre (vermelho) e doador de enxofre (verde), irradiados e não irradiados. 


\subsubsection{Efeito da irradiação na dureza dos composto de borrachas butílicas e halobutílicas irradiadas seguidas de cisalhamento}

Os resultados de dureza das borrachas butílicas, bromobutílicas e clorobutílicas curadas com resina, enxofre e doador de enxofre, irradiadas e cisalhadas estão apresentados na FIG. 63.

A amostra 1 (butílica curada com resina) mostrou similaridade de valores para todas as doses, sugerindo que a superfície da amostra se oxidou intensamente já em baixas doses, e também competição entre cisão e reticulação. Provavelmente pelo baixo índice de cura deste composto, uma vez que a reação de reticulação com resina, não contém enxofre, e, portanto, é mais lenta. Provavelmente o aquecimento adicional promovido pela mastigação mecânica, formou novas reticulações, que equilibraram a cisão.

A amostra 2 (butílica curada com enxofre) mostrou decréscimo de valor de dureza para doses baixas, indicando elevada cisão de cadeia. Para doses superiores a 50 kGy, equivalência de valores de dureza, sugerindo ocorrência simultânea de cisão e reticulação com predominância da reticulação. Na amostra de borracha butílica curadas com doador de enxofre, (amostra 3), nota-se que ocorre um ligeiro acréscimo com a dose. Sugerindo ocorrência de cisão e reticulação com o predomínio da cisão.

Os resultados de dureza de todas as amostras de borrachas halobutílicas curadas com resina, enxofre e doador de enxofre, mostraram para as doses entre 5 kGy e 100 kGy, valores de dureza equivalentes, mais uma vez evidenciando a competição entre cisão e reticulação. Entre as doses de 150 kGy e 200 kGy, aumento dos valores de dureza, indicando uma superfície oxidada pela radiação. 
(a)

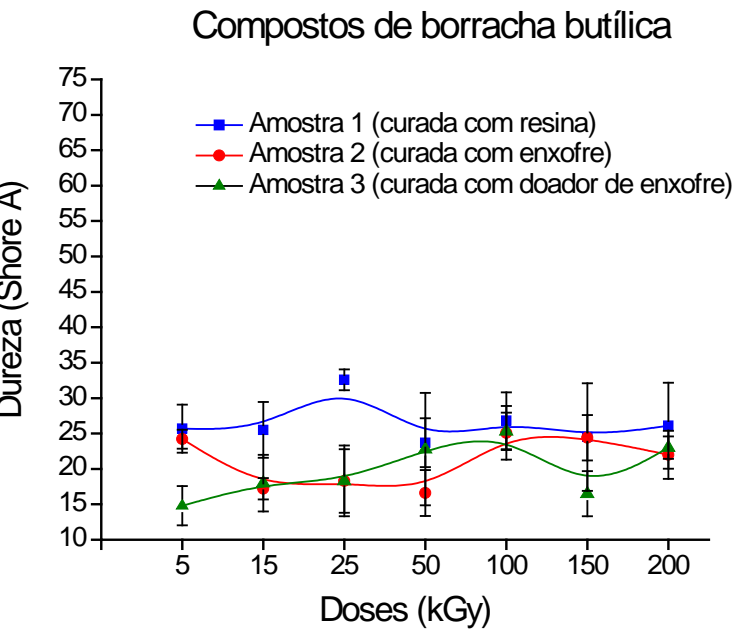

(b) Compostos de borracha bromobutílica

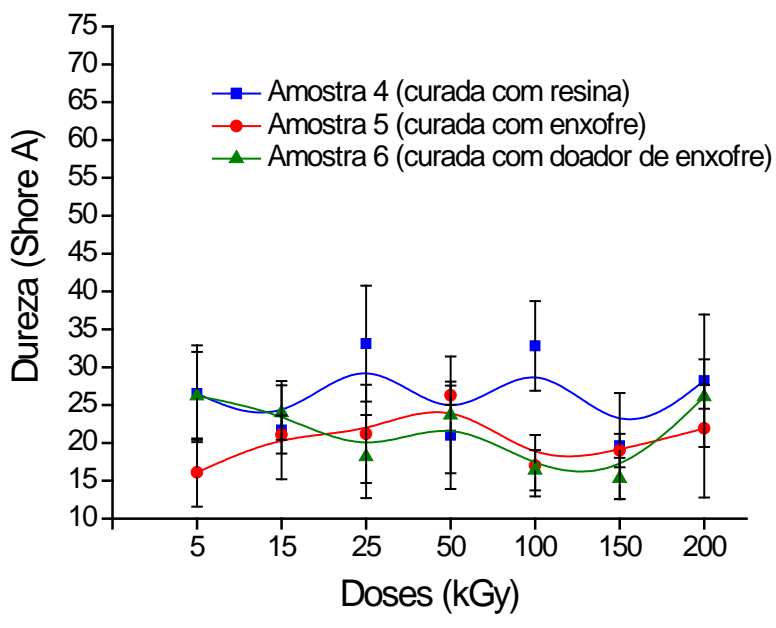

(c)

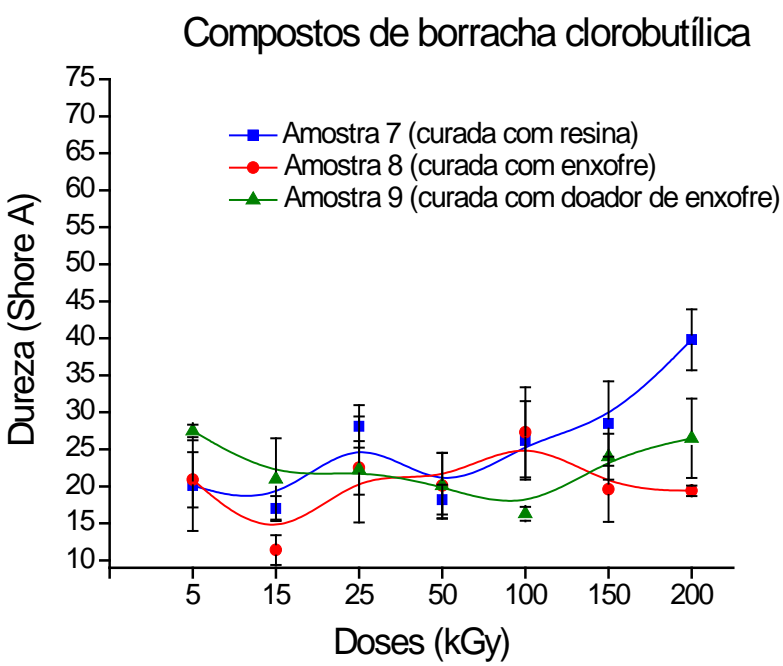

FIGURA 63: Efeito da dose de radiação e cisalhamento na dureza dos compostos de borracha (a) butílica, (b) bromobutílica e (c) clorobutílica curada com resina (azul), enxofre (vermelho) e doador de enxofre (verde). 


\subsection{Inchamento (Swelling)}

\subsubsection{Inchamento (Swelling) dos compostos de borracha butílica irradiadas}

O índice de inchamento é determinado, comparando-se a massa inicial da amostra com a massa final, as variações indicam mudanças no sistema de polimerização. Nas borrachas ocorre o fenômeno de inchamento o qual é inversamente proporcional à densidade de ligações cruzadas ${ }^{155}$. As borrachas vulcanizadas são insolúveis em solventes porque a presença de ligações cruzadas entre as cadeias impede que as moléculas sejam separadas pelo solvente. Porém elas possuem a capacidade de absorver líquidos, o que causa um aumento do seu volume, conhecido como fenômeno do inchamento em solventes. O inchamento no equilíbrio por solvente orgânico é um dos métodos mais simples para caracterizar a estrutura reticulada dos elastômeros.

A variação em massa dos corpos de prova foi acompanhada diariamente e os resultados são mostrados na FIG. 64, onde são exibidos os resultados para a média de três medidas em cada tempo.

Observou-se que a estabilidade mássica de todos os compostos, independente da formulação e do sistema de cura empregado, ocorreu após 24 horas de imersão no tolueno, pois o polímero incha até alcançar um grau de intumescimento de equilíbrio ${ }^{156,157 .}$

Os resultados mostrados na FIG. 64 evidenciam equilíbrio nos valores de inchamento após 24 horas de imersão no tolueno, indicando estabilização da formação de ligações cruzadas. A TAB. 13 apresenta a variação de massa seca em função da dose de irradiação, valores estes obtidos após o ensaio de inchamento das amostras de borracha butílica curada com resina (amostra 1), enxofre (amostra 2) e doador de enxofre (amostra 3), depois de secas durante 24 horas a temperatura ambiente. 
(a) Composto de borracha butílica curada com resina

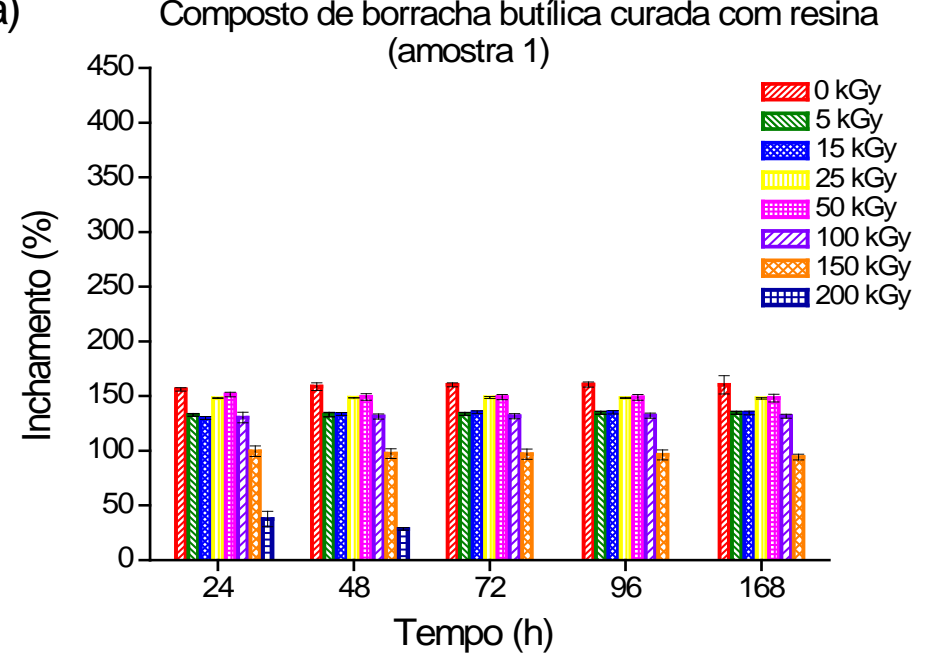

(b) Compostos de borracha butílica curada com enxofre

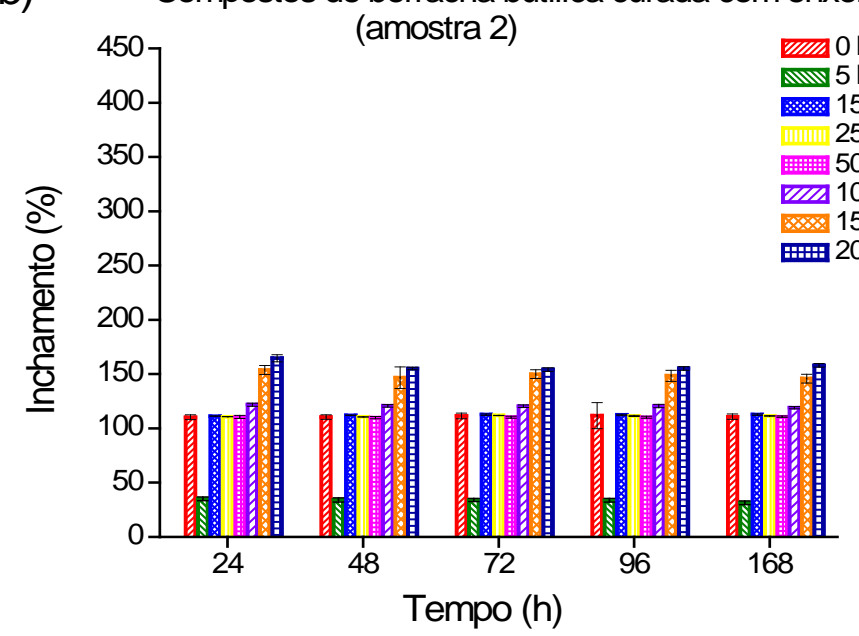

(c) Composto de borracha butílica curada com doador de enxofre

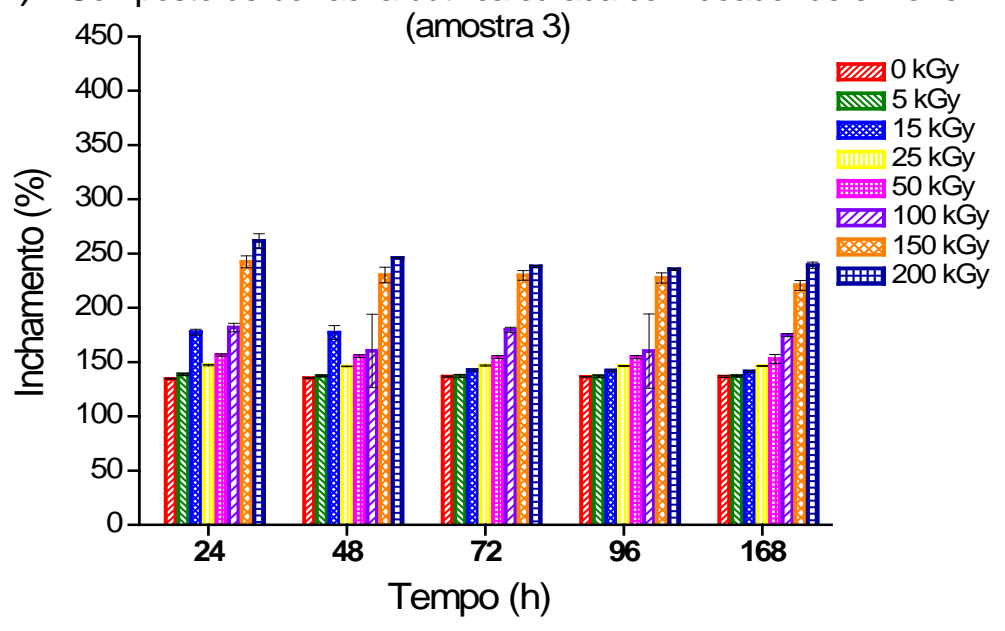

FIGURA 64: Resultado do inchamento dos compostos de borracha butílica curados com resina(a) (amostra 1), enxofre (b) (amostra 2) e doador de enxofre (c) (amostra 3) irradiados nas doses de 5, 15, 25, 50, 100, 150, e 200 kGy e não irradiados. 
TABELA 13: Variação da massa seca dos compostos de borracha butílica curado com resina, enxofre e doador de enxofre, irradiados e não irradiados.

\begin{tabular}{cccc}
\hline Amostras/Doses & $\begin{array}{c}\text { Amostra 1 } \\
\text { (curada com resina) } \\
\%\end{array}$ & $\begin{array}{c}\text { Amostra 2 } \\
\text { (curada com } \\
\text { enxofre) } \\
\%\end{array}$ & $\begin{array}{c}\text { Amostra 3 } \\
\text { (curada com } \\
\text { doador de enxofre) } \\
\%\end{array}$ \\
\hline $0 \mathrm{kGy}$ & 4,63 & $-1,56$ & $-1,19$ \\
$25 \mathrm{kGy}$ & 1,65 & $-9,11$ & $-7,73$ \\
$200 \mathrm{kGy}$ & - & $-15,44$ & $-24,94$ \\
\hline
\end{tabular}

A amostra 1 (butílica curada com resina) mostrou valores equivalentes de inchamento até a dose de 50 kGy, indicando que a cisão e reticulação, atuam com igual intensidade. Pode-se considerar que a cisão seja um pouco mais intensa, pois houve perda de massa nas medidas de inchamento conforme visto na TAB.13. Já para doses entre 100 kGy e 200 kGy houve decréscimo abrupto da massa com solubilização total do polímero na dose de 200 kGy, conforme mostrado na FIG. 65 e TAB 13. Demonstrando a ampla cisão de cadeia sofrida por esse sistema.

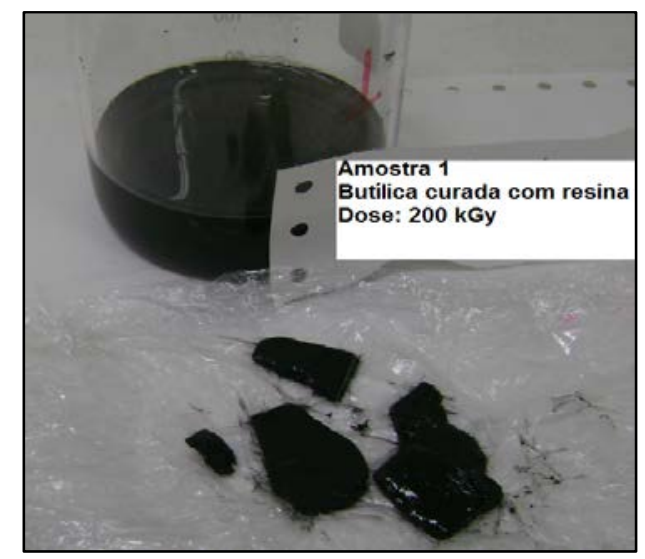

FIGURA 65: Imagem do composto de (borracha butílica curada com resina amostra 1), na dose de 200 kGy, após o teste de inchamento.

Para os compostos de borracha butílica curados com enxofre e doador de enxofre (amostra 2 e amostra 3) também apresentaram estabilidade de inchamento após 24 horas. A borracha butílica curada com enxofre mostrou uma diminuição intensa do inchamento na dose de 5 kGy e rápida recuperação dos valores originais em doses até 100 kGy. Aparentemente ocorre uma reticulação 
intensa que torna a cadeia rígida seguida de rápida degradação à medida que a irradiação prossegue. Para doses superiores a 100 kGy, observou-se, para ambos os sistemas de cura, um aumento expressivo de inchamento, em virtude do decréscimo da densidade de reticulação, indicando intensa cisão de cadeia, permitindo que o solvente penetre mais fácil na cadeia polimérica. Deve-se ressaltar que a partir de 25 kGy os resultados são muito afetados pela perda de massa das amostras, conforme mostrado na TAB.13. Portanto os valores reais de inchamento seriam ainda maiores se não houvesse a diluição de parte considerável da amostra.

Pode-se perceber que todas as amostras mostraram progressiva diminuição de massa em relação à massa inicial. A amostra 1 mostrou um ganho de massa de 0 kGy a 25 kGy, mas esse ganho se deve a presença residual do solvente. Com o aumento da dose, esta variação torna-se mais acentuada, chegando a cerca de $25 \%$ para a borracha curada com enxofre e atingindo a solubilização para a borracha curada com resina. Esta perda de massa está relacionada principalmente à extração de cadeias de baixa massa molar $^{158,159}$, mas também a presença de outros compostos do sistema de cura que podem ser extraídos ${ }^{160}$.

Os ensaios de intumescimento e variação de massa seca das amostras curadas com resina, enxofre e doador de enxofre mostraram a ampla predominância da cisão de cadeia com diminuição da massa molar; porém evidenciaram que a formação de reticulação pode ocorrer de forma intensa em condições específicas (borracha butílica curada com enxofre e irradiada com 5 kGy, amostra 2).

Outro fenômeno que ficou evidenciado é a maior fragilidade à radiação ionizante da borracha butílica curada com resina em virtude de sua solubilização completa após 72 horas no caso da borracha irradiada com 200 kGy. 


\subsubsection{Inchamento (Swelling) dos compostos de borracha bromobutílica irradiadas}

Os resultados de inchamento dos compostos de borracha bromobutílica curadas com resina (amostra 4), enxofre (amostra 5) e doador de enxofre (amostra 6) irradiados e não irradiados, estão apresentados na FIG. 66. Já a TAB. 14 apresenta a variação da massa seca em função da dose de irradiação, obtidos após o ensaio de inchamento das amostras de borracha bromobutílica curada com resina (amostra 4), enxofre (amostra 5) e doador de enxofre (amostra 6).

Similar aos resultados encontrados para as formulações de borracha butílica, os compostos de borracha bromobutílica apresentaram estabilidade de inchamento após 24 horas de imersão no solvente, mostrando que o tolueno se difundiu dentro das amostras de borracha rapidamente.

A amostra 4 (curada com resina) embora tenha mostrado estabilidade de inchamento após 24 horas, para doses superiores a 100 kGy, verificou-se elevado grau de inchamento em relação às outras doses, indicando que em doses mais baixas (até 50 kGy), existe competição entre cisão e reticulação, mas com predomínio de cisão, pois os valores de inchamento são afetados pela perda de massa apontada na TAB. 14. Já para doses mais elevadas o inchamento aumenta consideravelmente mesmo com perdas de massa na faixa de $20 \%$.

Os compostos curados com enxofre e doador de enxofre (amostra 5 e 6) mostraram equivalência de valores de inchamento mesmo após 168 horas de imersão no solvente, sugerindo intensidades equivalentes de cisão de cadeia e reticulação, porém como se verificou perda de massa de 22\% (TAB.14), que alteram significativamente os valores, fica evidente que a cisão de cadeia ou de reticulações é mais intensa. 
(a) Composto de borracha bromobutílica curada com resina

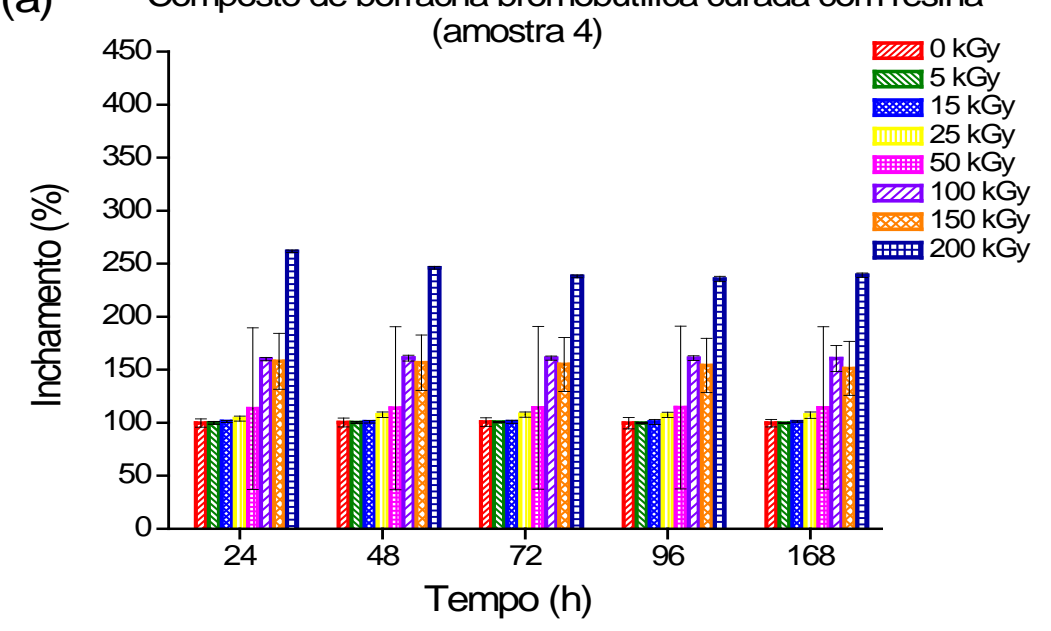

(b) Composto de borracha bromobutílica curada com enxofre

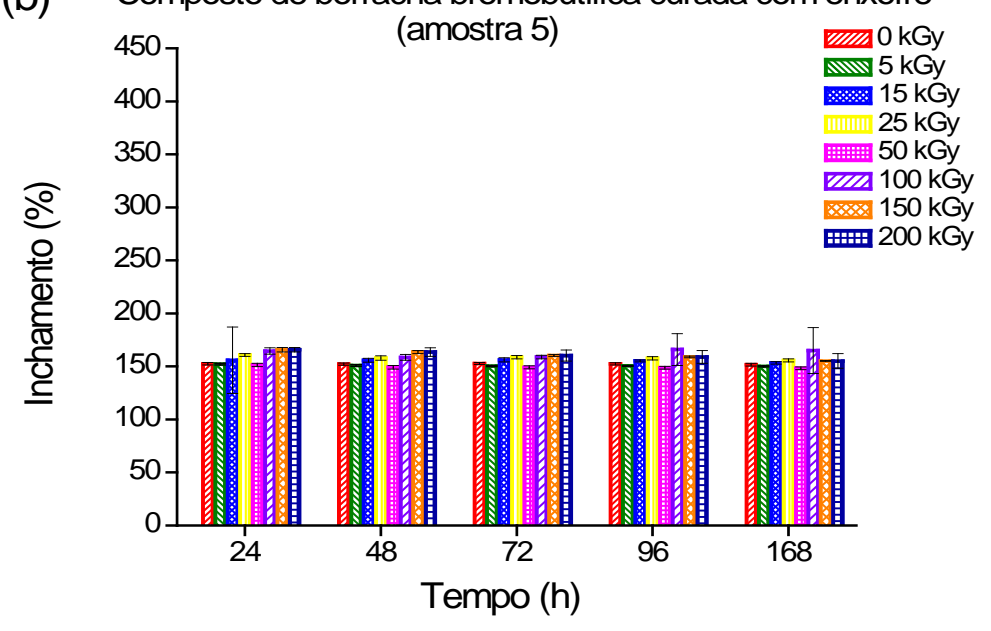

(c) Composto de borracha bromobutílica curada com doador de enxofre

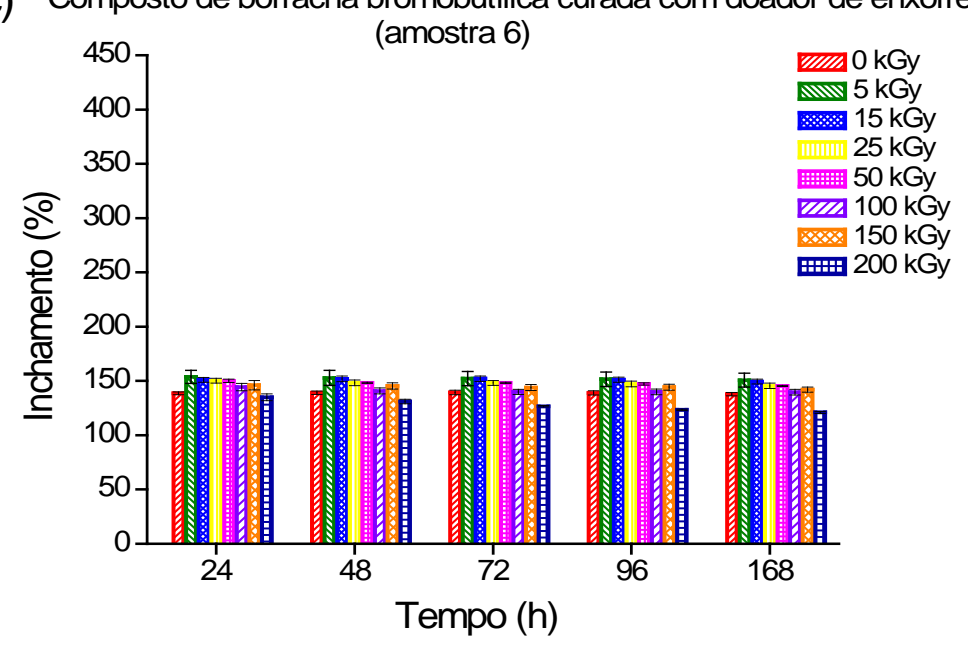

FIGURA 66: Resultado do inchamento dos compostos de borracha bromobutílica curados com resina) (a) (amostra 4), enxofre (b) (amostra 5) e doador de enxofre (c) (amostra 6) irradiadas nas doses de 5, 15, 25, 50, 100, 150, e 200 kGy e não irradiadas. 
Outro fenômeno que ficou evidenciado é a maior fragilidade à radiação ionizante da borracha bromobutílica curada com resina em virtude de variações de valores de inchamento muito mais elevadas

TABELA 14: Variação da massa seca dos compostos de borracha bromobutílica curados com resina, enxofre e doador de enxofre, irradiados e não irradiados.

\begin{tabular}{cccc}
\hline Amostras/Doses & $\begin{array}{c}\text { Amostra 4 } \\
\text { (curada com resina) } \\
\%\end{array}$ & $\begin{array}{c}\text { Amostra 5 } \\
\text { (curada com } \\
\text { enxofre) } \\
\%\end{array}$ & $\begin{array}{c}\text { Amostra 6 } \\
\text { (curada com } \\
\text { doador de enxofre) } \\
\%\end{array}$ \\
\hline $0 \mathrm{kGy}$ & 9,44 & $-3,71$ & $-0,91$ \\
$25 \mathrm{kGy}$ & 13,76 & $-11,11$ & $-11,67$ \\
$200 \mathrm{kGy}$ & $-19,88$ & $-21,71$ & $-21,89$ \\
\hline
\end{tabular}

Os resultados apresentados na TAB 14 mostraram para todos os compostos progressiva perda de massa. O aumento de massa da amostra 4 se deve a secagem insuficiente em 24 horas conforme o método aplicado. Esses resultados confirmam a predominância da cisão de cadeia.

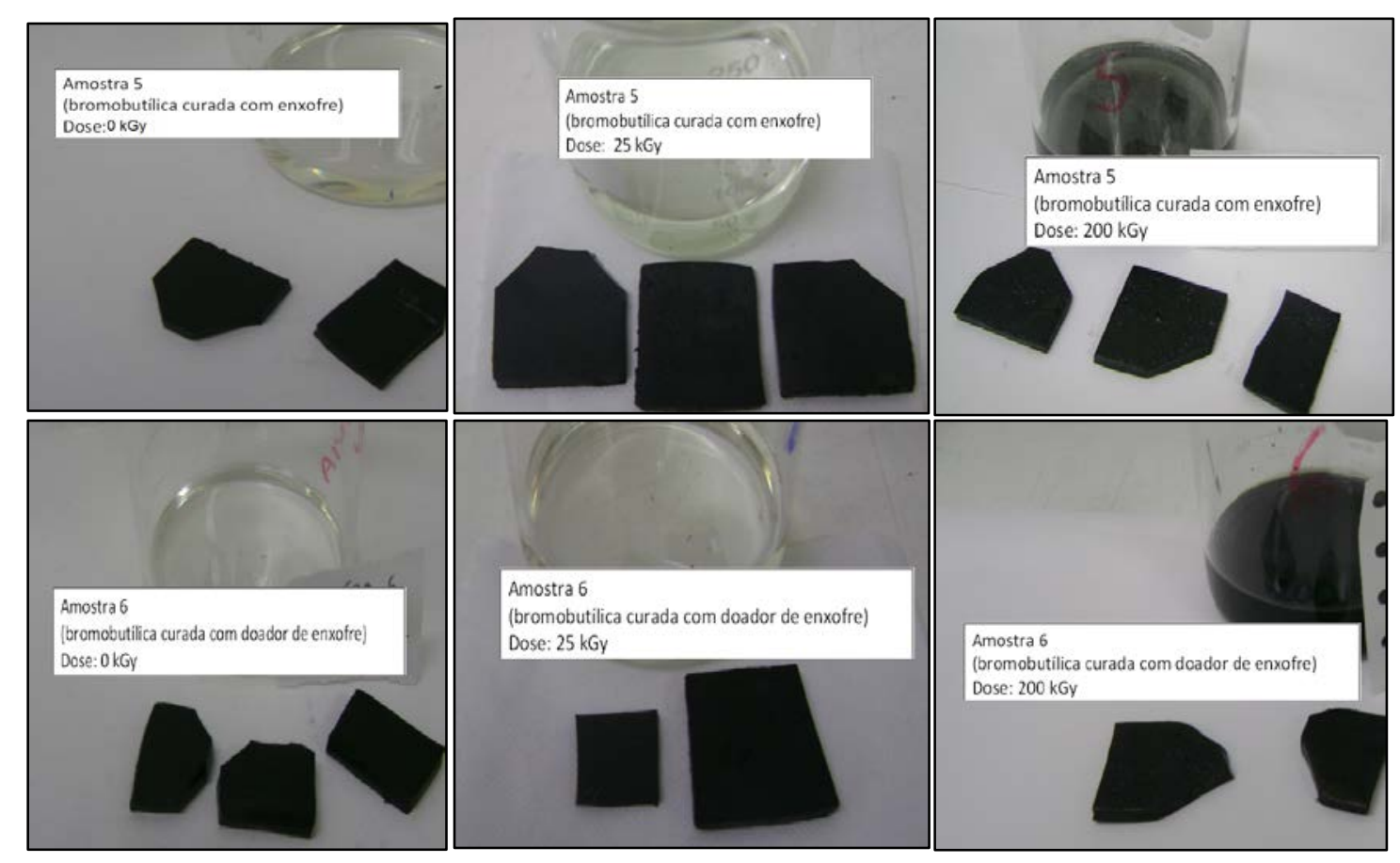

FIGURA 67: Imagem das formulações de borrachas bromobutílicas curadas com enxofre (amostra 5) e doador de enxofre (amostra 6) sem irradiação e irradiadas nas doses de $25 \mathrm{kGy}$ e 200 kGy, após o teste de inchamento. 
A FIG. 67 mostra o aspecto visual do solvente, com o aparecimento da coloração amarela durante o período de imersão das amostras de borracha bromobutílica, curadas com enxofre e doador de enxofre (amostras 5 e 6), especialmente para dose de 200 kGy, além da solubilização de parte da amostra em virtude do elevado grau de degradação dos compostos.

\subsubsection{Inchamento (Swelling) dos compostos de borracha clorobutílica irradiados}

A FIG 68 apresenta os resultados de inchamento dos compostos de borracha clorobutílica curadas com resina (amostra 7), enxofre (amostra 8) e doador de enxofre (amostra 9) irradiado e não irradiados. Já a TAB. 15 mostra a variação de massa seca, em função da dose de irradiação, obtida através do ensaio de inchamento para as mesmas amostras.

Os resultados de inchamento mostrados na FIG. 68 e TAB. 15 foram similares aos encontrados para as borrachas butílicas e bromobutílicas, no que se refere à estabilidade de inchamento depois de 24 horas de imersão no tolueno e à perda de massa respectivamente. Com o aumento da dose ocorre um aumento do inchamento e aumento de perda de massa que pode estar associados a uma diminuição da quantidade de ligações cruzadas.

O composto de borracha clorobutílica curado com doador de enxofre (amostra 9) apresentou um comportamento bem peculiar, pois mostrou um enorme decréscimo do inchamento nas doses de 5 a 15 kGy, seguido de uma recuperação dos valores iniciais para a dose de 25 KGy e a partir dessa dose diminuição do inchamento. A queda dos valores está associada à formação de novas reticulações e o aumento do inchamento à cisão de cadeia. Um aspecto interessante desse ensaio foi a queda acentuada do inchamento já em 5 kGy, mostrando que a borracha clorobutílica curada com doador de enxofre é muito sensível radiação já em baixas doses, provavelmente pela presença do cloro em maior quantidade se comparada com a bromobutílica. Outro aspecto observado foi o decréscimo seguido de aumento considerável do inchamento, levando-se a 
supor que a estrutura muito reticulada ficou por demais rígida e sofreu intensa cisão com a continuidade da irradiação até 25 kGy.

(a) Composto de borracha clorobutílica curada com resina

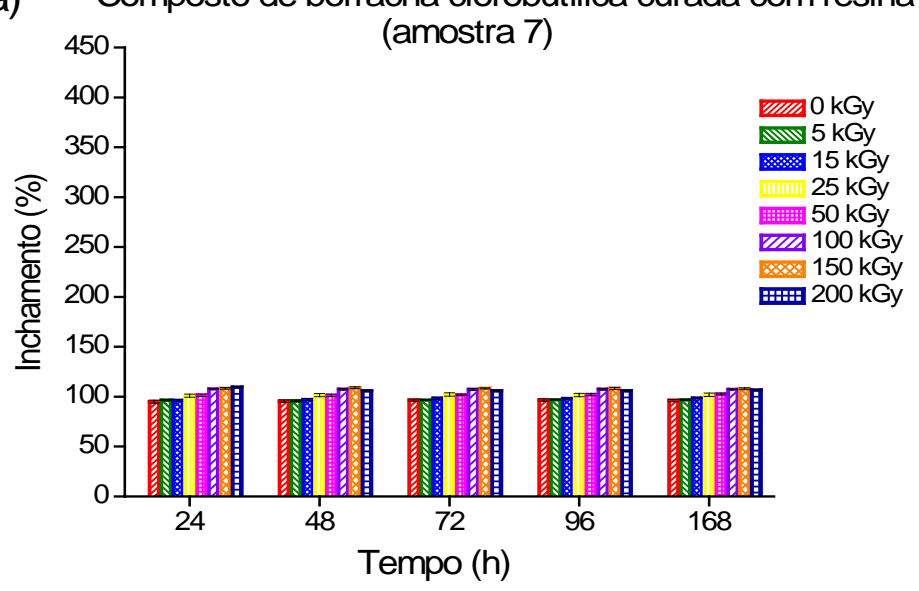

(b) Composto de borracha clorobutílica curada com enxofre

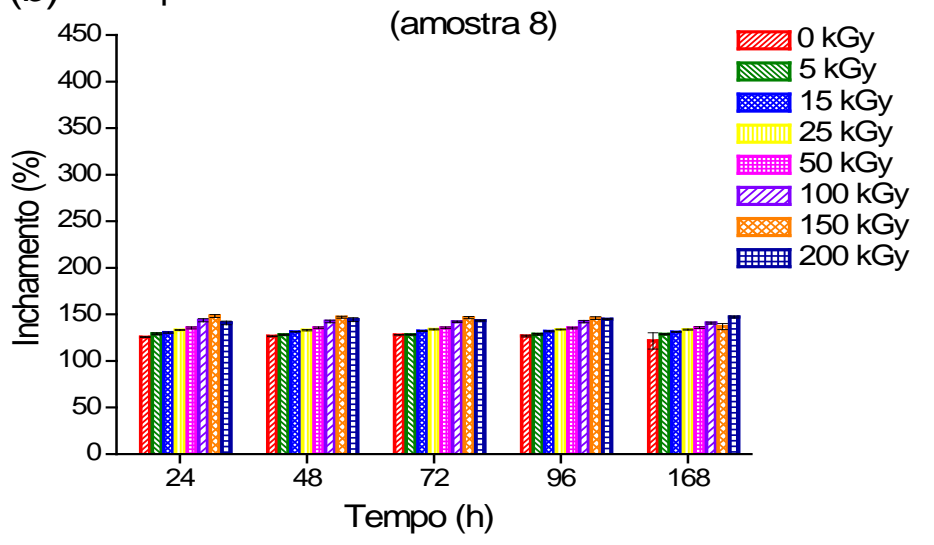

(c) Composto de borracha clorobutílica curada com

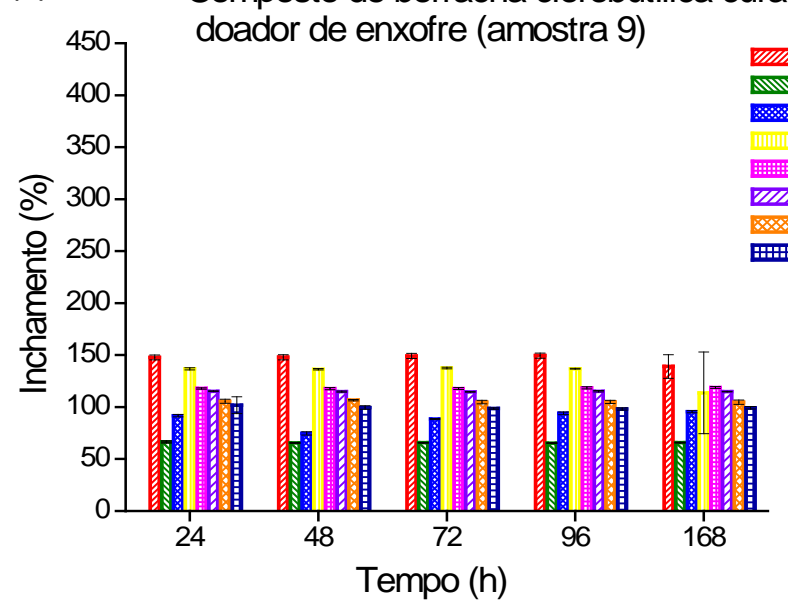

FIGURA 68: Resultado do inchamento dos compostos de borracha clorobutílica curados com resina (a) (amostra 7), enxofre (b) (amostra 8) e doador de enxofre (c)(amostra 9) irradiadas nas doses de 5, 15, 25, 50, 100, 150, e 200 kGy e não irradiadas. 
TABELA 15: Variação da massa seca dos compostos de borracha clorobutílica curados com resina, enxofre e doador de enxofre, irradiados e não irradiados.

\begin{tabular}{cccc}
\hline Amostras/Doses & $\begin{array}{c}\text { Amostra } 7 \\
\text { (curada com } \\
\text { resina) } \%\end{array}$ & $\begin{array}{c}\text { Amostra 8 } \\
\text { (curada com } \\
\text { enxofre) } \\
\%\end{array}$ & $\begin{array}{c}\text { Amostra 9 } \\
\text { (curada com } \\
\text { doador de } \\
\text { enxofre) } \\
\%\end{array}$ \\
\hline $0 \mathrm{kGy}$ & 8,08 & $-0,82$ & $-5,39$ \\
$25 \mathrm{kGy}$ & 1,77 & $-8,91$ & $-5,03$ \\
$200 \mathrm{kGy}$ & $-1,39$ & $-8,23$ & $-4,88$ \\
\hline
\end{tabular}

A variação de massa seca apresentada na TAB. 15 mostrou que as amostras curadas com resina e enxofre (amostras 8 e 9) apresentam extração de moléculas provavelmente de baixa massa molar.

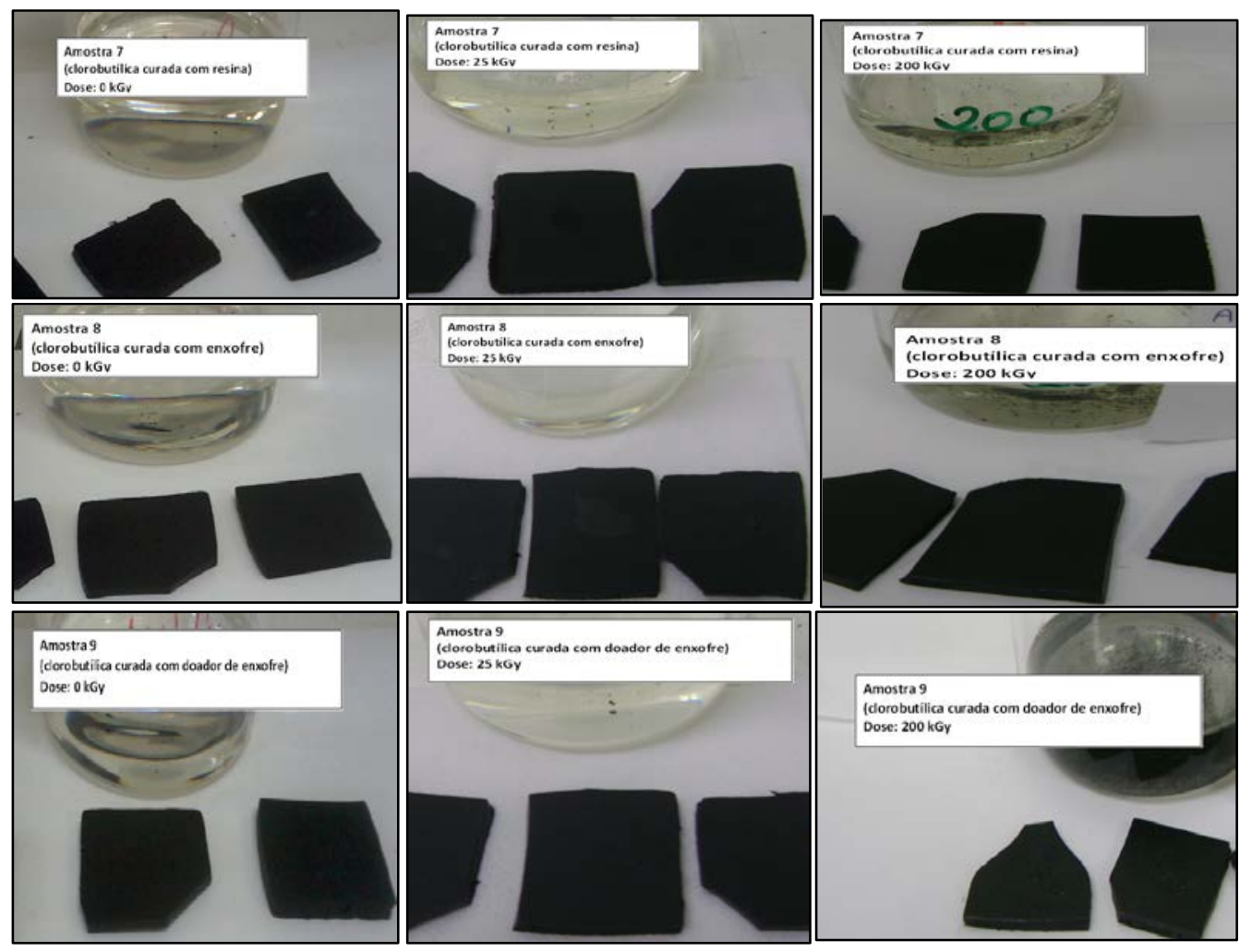

FIGURA 69: Imagem das formulações de compostos de borracha clorobutílica curadas com resina (amostra 7) enxofre (amostra 8) e doador de enxofre (amostra 9) sem irradiação e irradiadas nas doses de 25 kGy e 200 kGy após o teste de inchamento. 
A formulação de borracha clorobutílica curada com doador de enxofre (amostra 9) mostrou uma perda de massa uniforme de 0 a 200 kGy, confirmando os resultados de inchamento que mostraram fenômenos intensos de reticulação e cisão ocorrendo em etapas distintas da irradiação.

A FIG. 69 mostra o aspecto visual das amostras, dos compostos de borracha clorobutílica curados com resina (amostra 7), enxofre (amostra 8) e doador de enxofre (amostra 9) irradiados nas doses de 25 kGy e 200 kGy, e do solvente.

\subsubsection{Inchamento (Swelling) dos compostos de borracha butílica irradiados e cisalhados}

O índice de inchamento das amostras irradiadas e cisalhada da borracha butílica, curada com resina, enxofre e doador de enxofre, estão apresentados na FIG. 70. Já a TAB. 16 apresenta a variação de massa seca em função da dose de irradiação e do cisalhamento, para as mesmas amostras.

Observou-se também nesse caso a estabilidade de inchamento obtido após 24 horas de imersão da amostra no solvente para todas as amostras. O composto 1 (curado com resina) mostrou que a irradiação seguida de cisalhamento mecânico promoveu a degradação ampla do polímero já na dose de 15 kGy, e em doses superiores a 50 kGy fica evidente a solubilização total, sugerindo que a cisão de cadeia, causada pela irradiação foi aumentada pelo cisalhamento mecânico e a degradação oxidativa.

Para os compostos butílicos curados com enxofre (amostra 2) em baixas doses, verifica-se aumento considerável do inchamento associado à intensa cisão de cadeia. Para doses intermediárias, após 24 horas de imersão no solvente verifica-se a completa dissolução da amostra. 
(a)

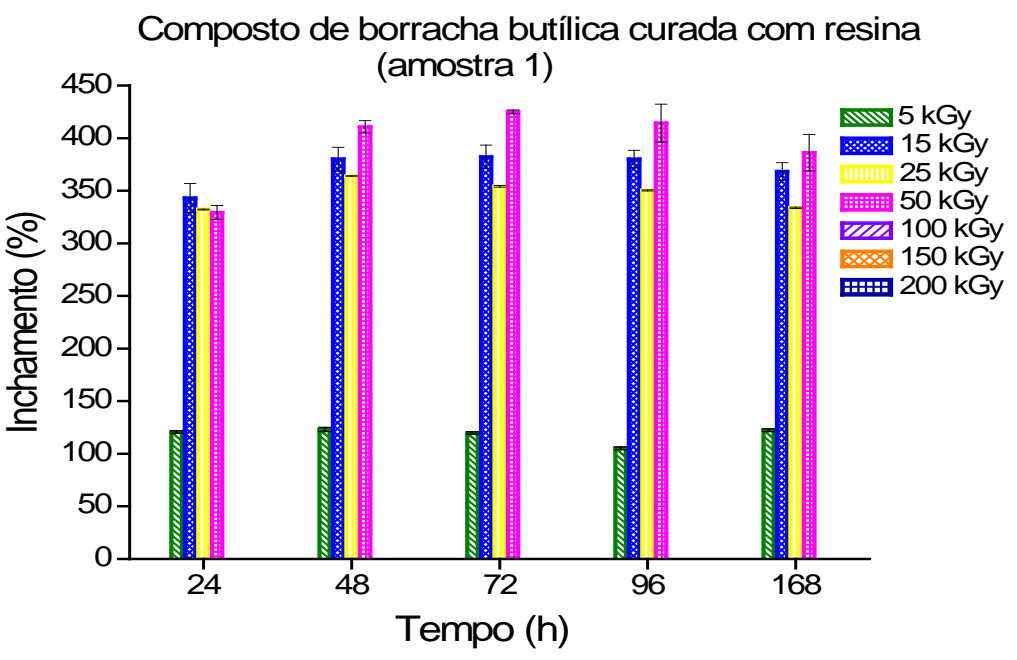

(b) Composto de borracha butílica curada com enxofre

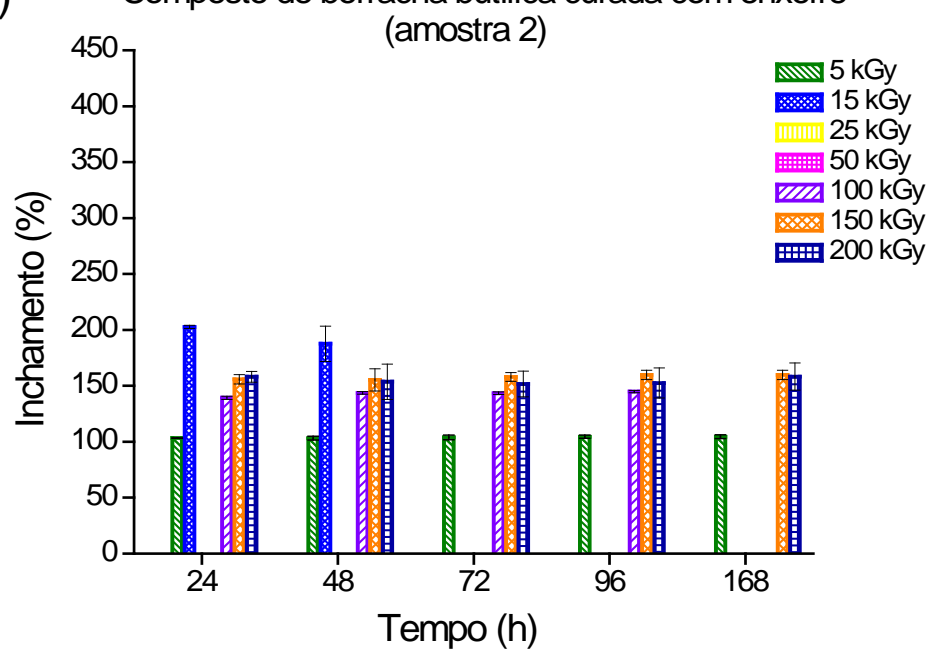

(c) Composto de borracha butílica curada com doador de enxofre

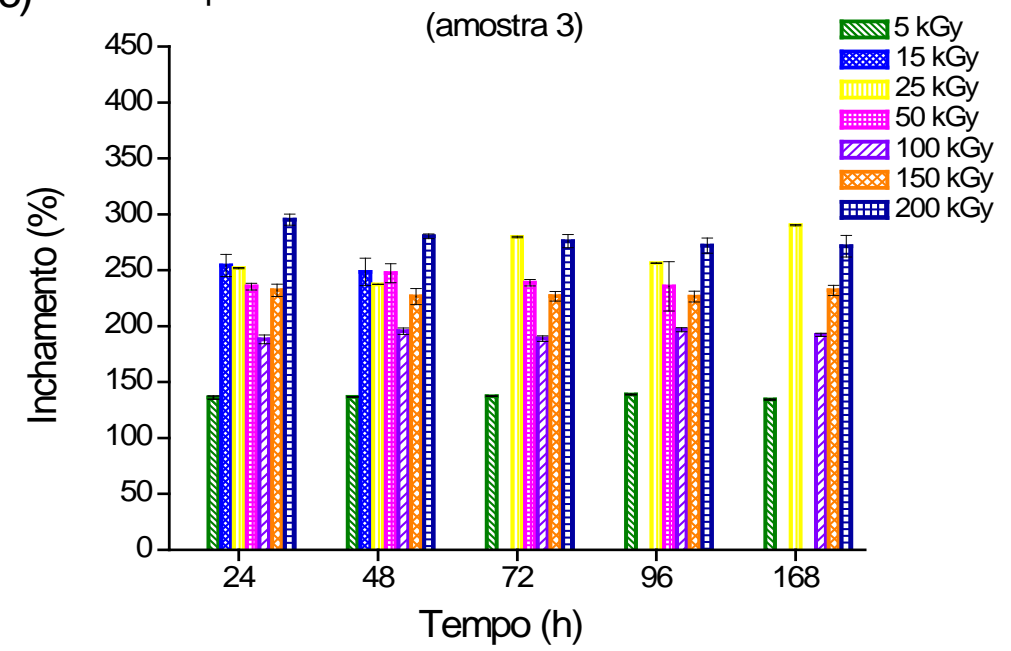

FIGURA 70: Resultado do inchamento dos compostos de borracha butílica curados com resina (a) (amostra 1), enxofre (b) (amostra 2) e doador de enxofre (c) (amostra 3) irradiados nas doses de 5, 15, 25, 50, 100, 150 e 200 kGy e cisalhados. 
Já para doses acima de 100 kGy, verifica-se uma inversão do fenômeno, isto é a não dissolução da amostra e intumescimento moderado. Essa ocorrência pode ser explicada pela formação de géis a partir dos fragmentos altamente degradados (presença de insaturações) e também a eventual formação de reticulações proveniente da oxidação da borracha. O mesmo acontece com a amostra 3 (curada com doador de enxofre) em doses baixas intensa cisão de cadeia, causada pela irradiação e a mastigação mecânica, para doses mais elevadas a recombinação de radicais promove novas reticulações e formação de gel, devido à presença de enxofre residual.

TABELA 16: Variação da massa seca do composto de borracha butílica curados com resina, enxofre e doador de enxofre, irradiadas e cisalhadas.

\begin{tabular}{cccc}
\hline Amostras/Doses & $\begin{array}{c}\text { Amostra 1 } \\
\text { (curada com } \\
\text { resina) } \\
\%\end{array}$ & $\begin{array}{c}\text { Amostra 2 } \\
\text { (curada com } \\
\text { enxofre) } \\
\%\end{array}$ & $\begin{array}{c}\text { Amostra 3 } \\
\text { (curada com } \\
\text { doador de } \\
\text { enxofre) } \\
\%\end{array}$ \\
\hline $0 \mathrm{kGy}$ & 4,63 & $-1,56$ & $-1,19$ \\
$25 \mathrm{kGy}$ & $-2,72$ & - & $-15,37$ \\
$200 \mathrm{kGy}$ & - & $-22,20$ & $-33,06$ \\
\hline
\end{tabular}

Os resultados da variação de massa seca apresentadas na TAB. 16 mostrou que o cisalhamento em amostras irradiadas, auxilia a degradação da cadeia polimérica, pelo aumento da cisão, comprometendo a integridade da amostra, promovendo a dissolução de ingredientes da formulação e a completa dissolução da borracha no solvente, indicando maior penetração das moléculas do solvente na rede polimérica.

A FIG. 71 mostra o aspecto visual dos compostos de borracha butílica curados com resina (amostra 1), enxofre (amostra 2) e doador de enxofre (amostra 3) irradiados na dose de 200 kGy e posteriormente cisalhados, após a imersão no solvente, onde se observa o elevado grau de degradação das amostras. 


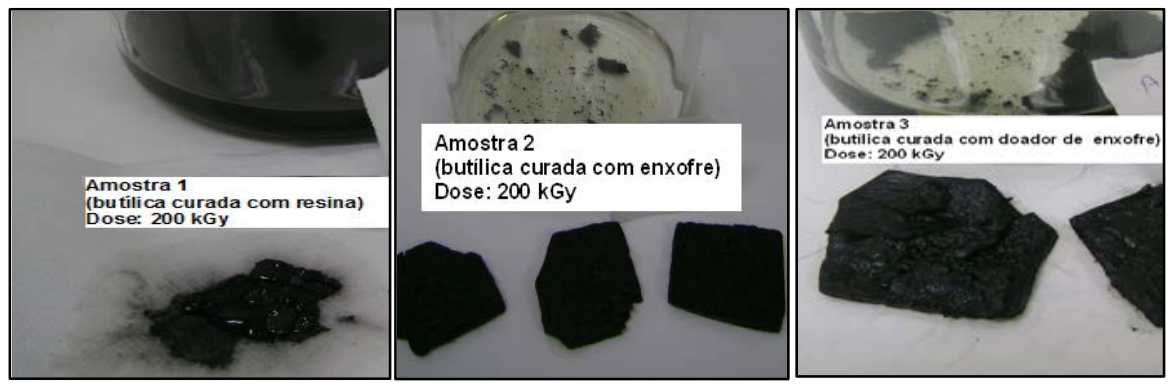

FIGURA 71: Imagem dos compostos de borracha butílica curados com resina (amostra 1) enxofre (amostra 2) e doador de enxofre (amostra 3) irradiados na dose de 200 kGy e cisalhados, após o teste de inchamento.

\subsubsection{Inchamento (Swelling) dos compostos de borracha bromobutílica irradiados e cisalhados}

Os resultados da variação de inchamento das amostras irradiadas e cisalhadas das borrachas bromobutílica curadas com resina, enxofre e doador de enxofre, estão apresentados na FIG. 72. Já a variação da massa seca em função da dose de irradiação e do cisalhamento, obtido através do ensaio de inchamento das mesmas amostras estão apresentados na TAB. 17.

Para a amostra 4 (curada com resina), na dose de 5kGy seguida de cisalhamento, se observa a manutenção dos valores de inchamento. Os valores de perda de massa da TAB. 17 sugerem que a cisão é mais importante que a reticulação. Já a enorme diferença de comportamento entre a borracha butílica e a bromobutílica sugere que as ligações de hidrogênio são as maiores responsáveis pelo comportamento estável. Já para doses superiores a 15 kGy, houve considerável aumento do índice de inchamento somente explicável pela elevada cisão de cadeia causada pela irradiação e aumentada pela mastigação mecânica com oxidação da borracha conforme já visto anteriormente. 


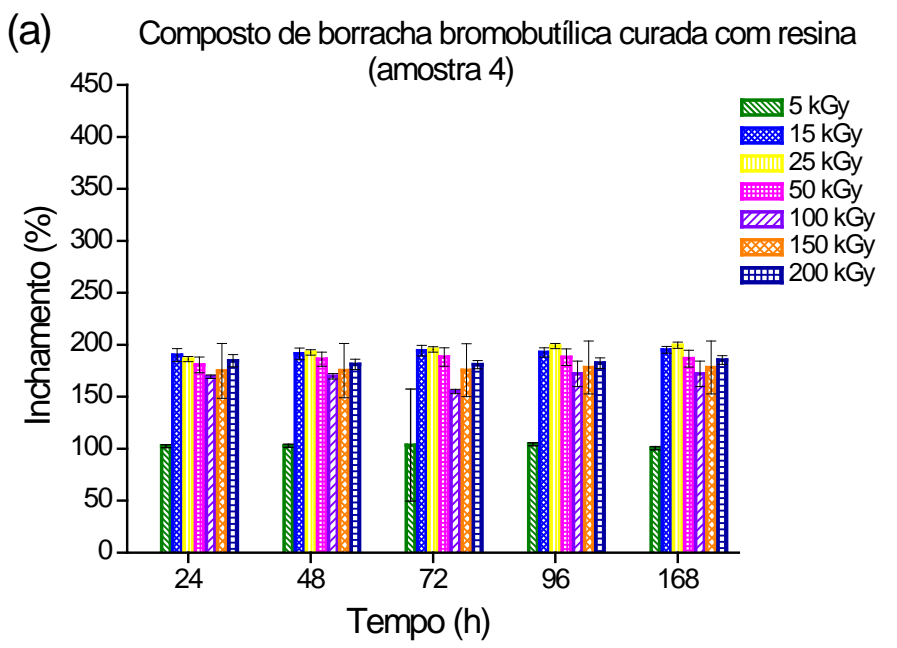

(b) Composto de borracha bromobutílica curada com enxofre
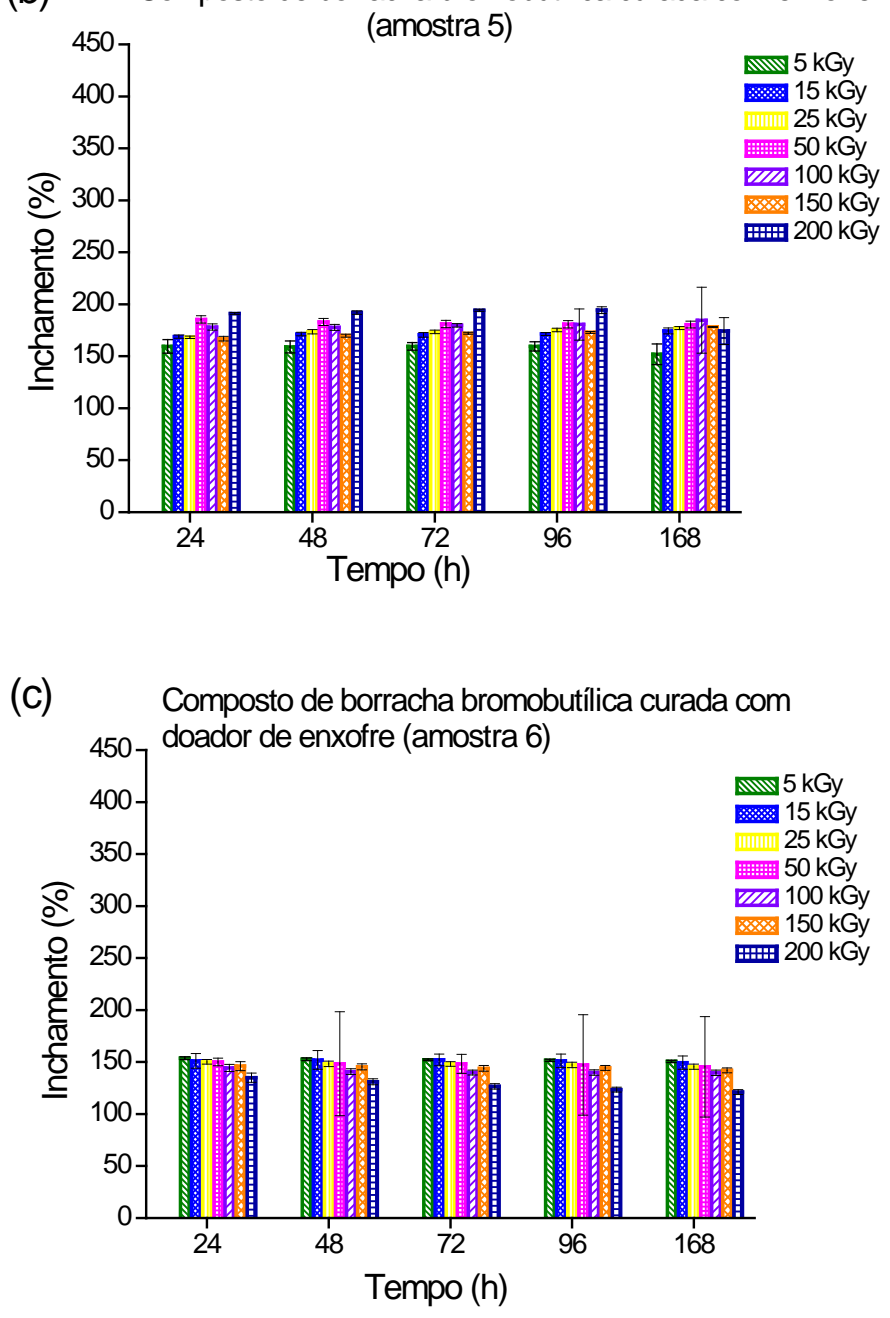

FIGURA 72: Resultado do inchamento dos compostos de borracha bromobutílica curados com resina (a) (amostra 4), enxofre (b) (amostra 5) e doador de enxofre (c) (amostra 6) irradiados nas doses de 5, 15, 25, 50, 100, 150 e 200 kGy e cisalhados. 
Para a amostra 5 (curada com enxofre) e amostra 6 (curada com doador de enxofre), se observou um aumento do inchamento para doses até 50 kGy, associado a uma considerável perda de massa (TAB. 17), sugerindo a ocorrência de cisão intensa. Para dose maiores verifica-se uma pequena diminuição do inchamento; porém associado à elevada perda de massa da ordem de 30\% (amostra 5). A amostra 6 apresenta a mesma tendência; porém, fica totalmente gelificada a 200 kGy. Portanto apesar de haver evidência de ampla cisão de cadeia, a geração simultânea de radicais durante a irradiação possibilita a criação de uma rede densamente reticulada.

TABELA 17: Variação da massa seca dos compostos de borracha bromobutílica curados com resina, enxofre e doador de enxofre, irradiados e cisalhados.

\begin{tabular}{cccc}
\hline Amostras/Doses & $\begin{array}{c}\text { Amostra 4 } \\
\text { (curada com resina) }\end{array}$ & $\begin{array}{c}\text { Amostra 5 } \\
\text { (curada com } \\
\text { enxofre) }\end{array}$ & $\begin{array}{c}\text { Amostra 6 } \\
\text { (curada com } \\
\text { doador de enxofre) }\end{array}$ \\
\hline 0 kGy & 9,44 & $-3,71$ & $-0,91$ \\
25 kGy & $-4,38$ & $-13,05$ & $-16,33$ \\
200 kGy & $-9,83$ & $-31,51$ & 0 \\
\hline
\end{tabular}

Os compostos de borracha bromobutílica curados com resina (amostra 1), enxofre (amostra 2) e doador de enxofre (amostra 3), irradiados a 200 kGy e cisalhados, imersos no solvente, são mostrados na FIG. 73, onde se verifica o aspecto quebradiço das amostras.

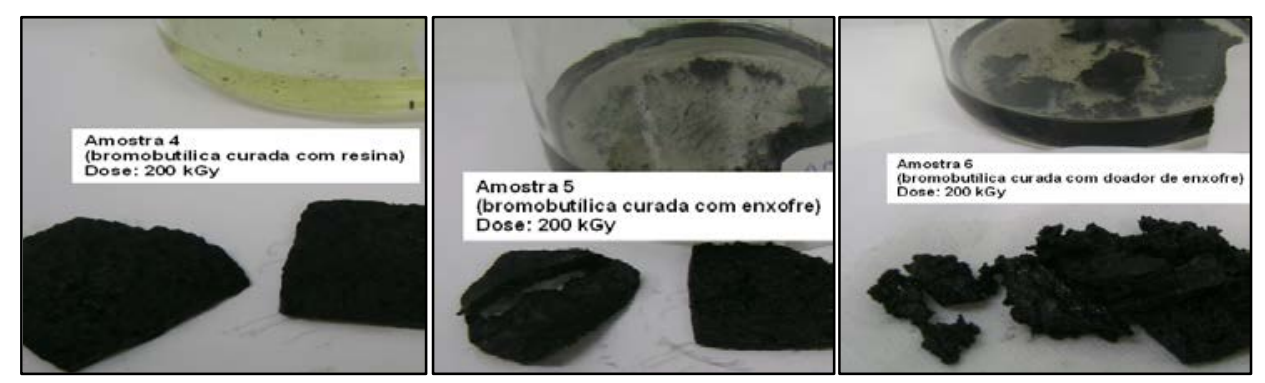

FIGURA 73: Imagem das borrachas bromobutílicas curadas com resina (amostra 4) enxofre (amostra 5) e doador de enxofre (amostra 6) irradiadas na dose de 200 kGy e cisalhadas após o teste de inchamento. 


\subsubsection{Inchamento (Swelling) dos compostos de borracha clorobutílica irradiados e cisalhados}

A variação do índice de inchamento em \% de massa das amostras de borracha clorobutílica curadas com resina (amostra 7), enxofre (amostra 8) e doador de enxofre (amostra 9), está apresentado na FIG. 74 e a variação de massa seca após o inchamento é mostrada na TAB. 18.

A porcentagem de variação de massa no inchamento das formulações de borracha clorobutílica, curada com resina, enxofre e doador de enxofre e cisalhadas apresentou inchamento mais elevados que os encontrados sem cisalhamento. Nesse caso também a longa permanência das amostras em contato com o solvente não promoveu nenhuma outra modificação, pois o equilíbrio de inchamento foi alcançado após 24 horas de imersão no tolueno.

Para as amostras curadas com resina (amostra 7) observou-se que para doses baixas, de $5 \mathrm{kGy}$ um inchamento baixo, sugerindo uma tendência a reticulação. Porém o resultado pode estar afetado por uma perda substancial da massa seca já no inicio da irradiação (TAB.18). Para doses mais elevadas até 50 kGy nota-se aumento da cisão e também maiores perdas de massa seca. Já para dose de 100 a 200 kGy ocorreu queda do inchamento com apenas um leve aumento da perda de massa. Esse conjunto de resultados sugere que a reticulação foi dominante após um período de indução, que pode ser associado à formação de duplas ligações provenientes da cisão molecular.

As formulações curadas com enxofre (amostra 8) e doador de enxofre (amostra 9) cisalhadas, para doses mais elevadas, verificou-se pelos valores de massa seca a ocorrência de cisão de cadeia. Porém assim como na borracha bromobutílica o aumento da massa seca é pequeno na faixa de 100 kGy a 200 kGy e ocorre uma diminuição significativa do inchamento, evidenciando que a reticulação ocorre com maior intensidade que a cisão. 
(a) Composto de borracha clorobutílica curada com resina

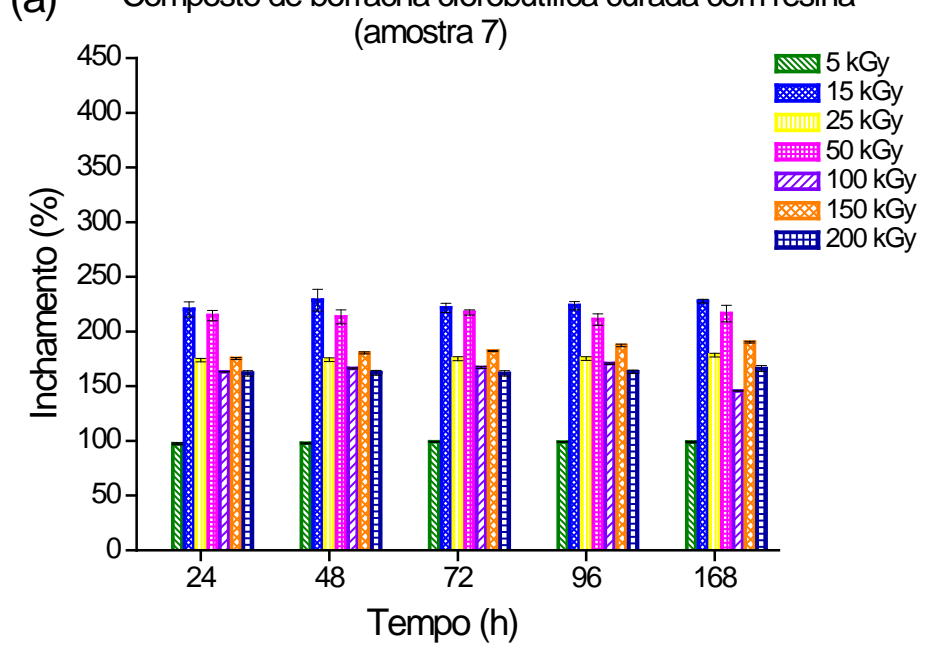

(b) Composto de borracha clorobutilica curada com enxofre
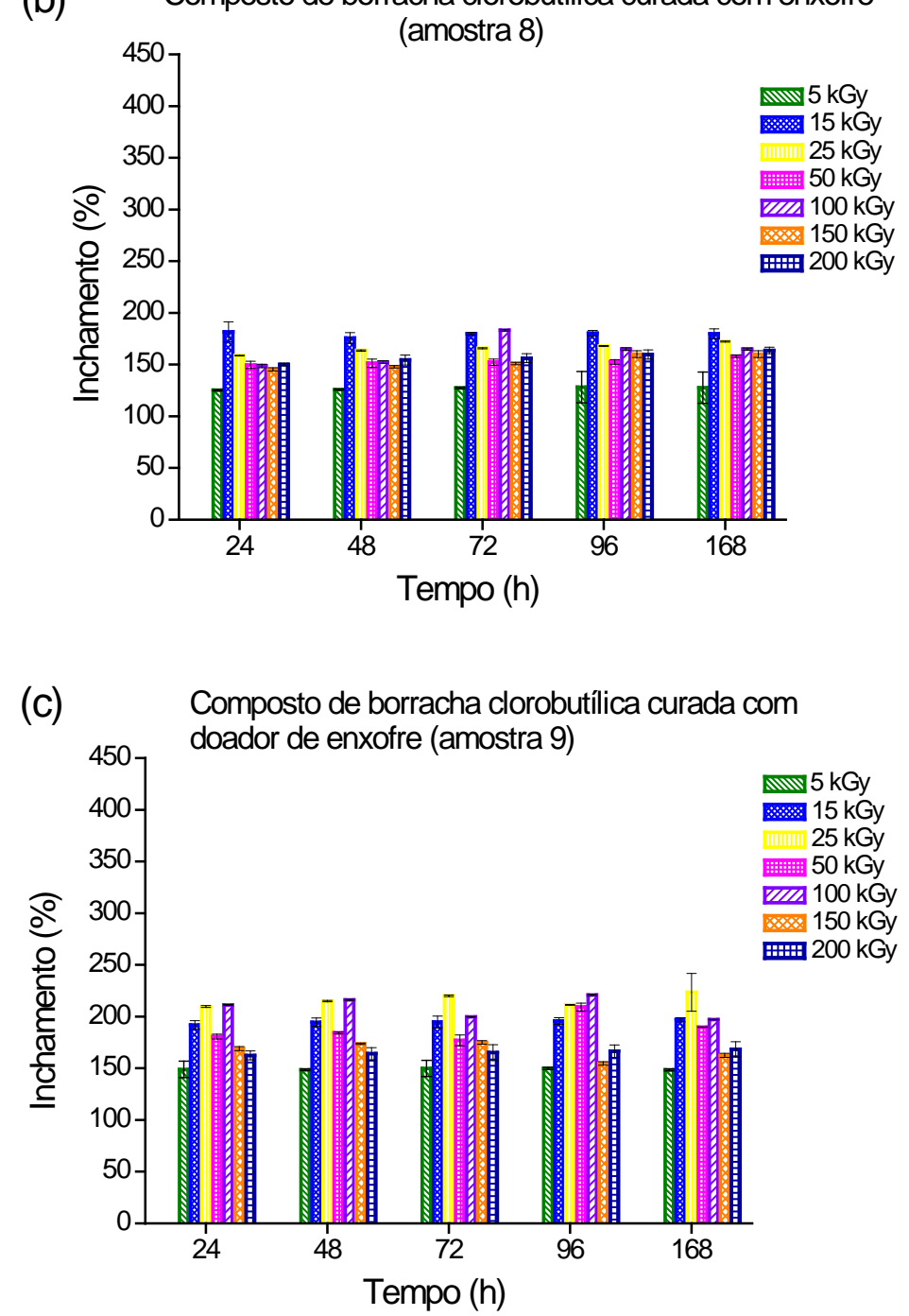

FIGURA 74: Resultado do inchamento dos compostos de borracha clorobutílica curados com resina (a) (amostra 7), enxofre (b) (amostra 8) e doador de enxofre (c) (amostra 9), irradiados nas doses de 5, 15, 25, 50, 100, 150 e 200 kGy e cisalhados. 
TABELA 18: Variação da massa seca dos compostos de borracha clorobutílica curados com resina, enxofre e doador de enxofre, irradiados e cisalhados.

\begin{tabular}{cccc}
\hline Amostras/Doses & $\begin{array}{c}\text { Amostra 7 } \\
\text { (curada com } \\
\text { resina) }\end{array}$ & $\begin{array}{c}\text { Amostra 8 } \\
\text { (curada com } \\
\text { enxofre) }\end{array}$ & $\begin{array}{c}\text { Amostra 9 } \\
\text { (curada com } \\
\text { doador de } \\
\text { enxofre) }\end{array}$ \\
\hline $0 \mathrm{kGy}$ & 8,08 & $-0,52$ & 5,39 \\
$25 \mathrm{kGy}$ & $-0,95$ & $-12,51$ & $-10,00$ \\
$200 \mathrm{kGy}$ & $-1,86$ & $-18,64$ & $-13,91$ \\
\hline
\end{tabular}

Pode-se verificar na TAB.18 que os compostos clorobutílicos curados com resina (amostra 7), enxofre (amostra 8) e doador de enxofre (amostra 9) mesmo com o intenso cisalhamento e a dissolução de ingredientes no solvente, apresentaram aspecto totalmente quebradiço em virtude da formação de gel.

A FIG. 75 mostra o aspecto visual das amostras de borracha clorobutílica curadas com resina (amostra 7), enxofre (amostra 8) e doador de enxofre (amostra 9) irradiadas na dose de 200kGy, onde se observa que não ocorreu a completa dissolução destas amostras no solvente mesmo depois de irradiadas e cisalhadas.
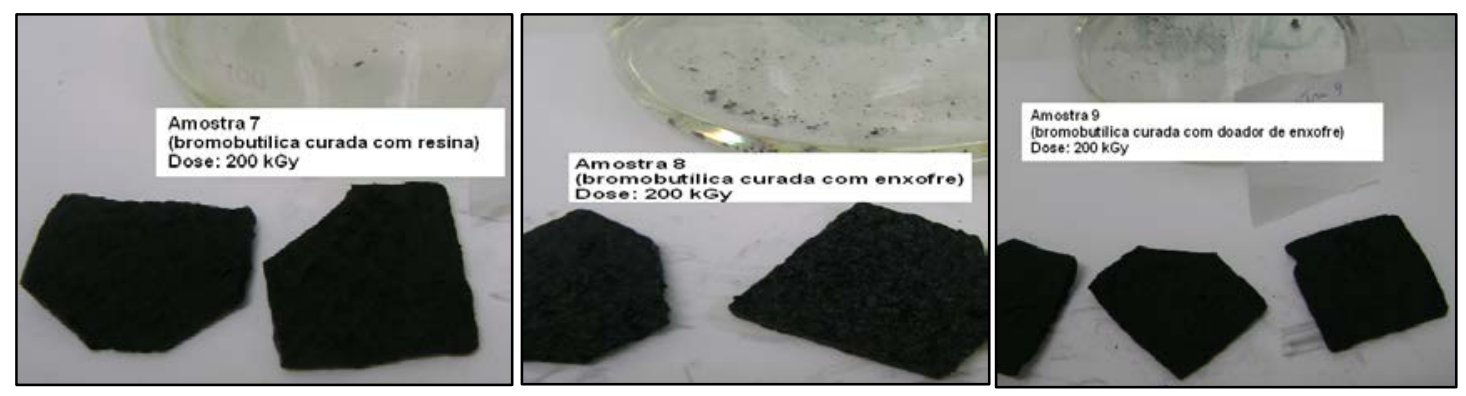

FIGURA 75: Imagem dos compostos de borracha clorobutílica curados com resina (amostra 7), enxofre (amostra 8) e doador de enxofre (amostra 9) irradiados na dose de 200 kGy e cisalhados, após o teste de inchamento. 


\subsection{Microscopia Eletrônica de Varredura (MEV) com EDS}

\subsubsection{Microscopia Eletrônica de Varredura (MEV) com EDS dos compostos de borrachas butílica e halobutílica irradiados}

As micrografias com aumento de 250 vezes e o EDS realizados na superfície de ruptura das amostras de borracha butílica curada com resina (amostra 1), enxofre (amostra 2) e doador de enxofre (amostra 3) e irradiadas nas doses de 25 kGy e 200, são apresentadas nas FIG. 76, 77 e 78 respectivamente.
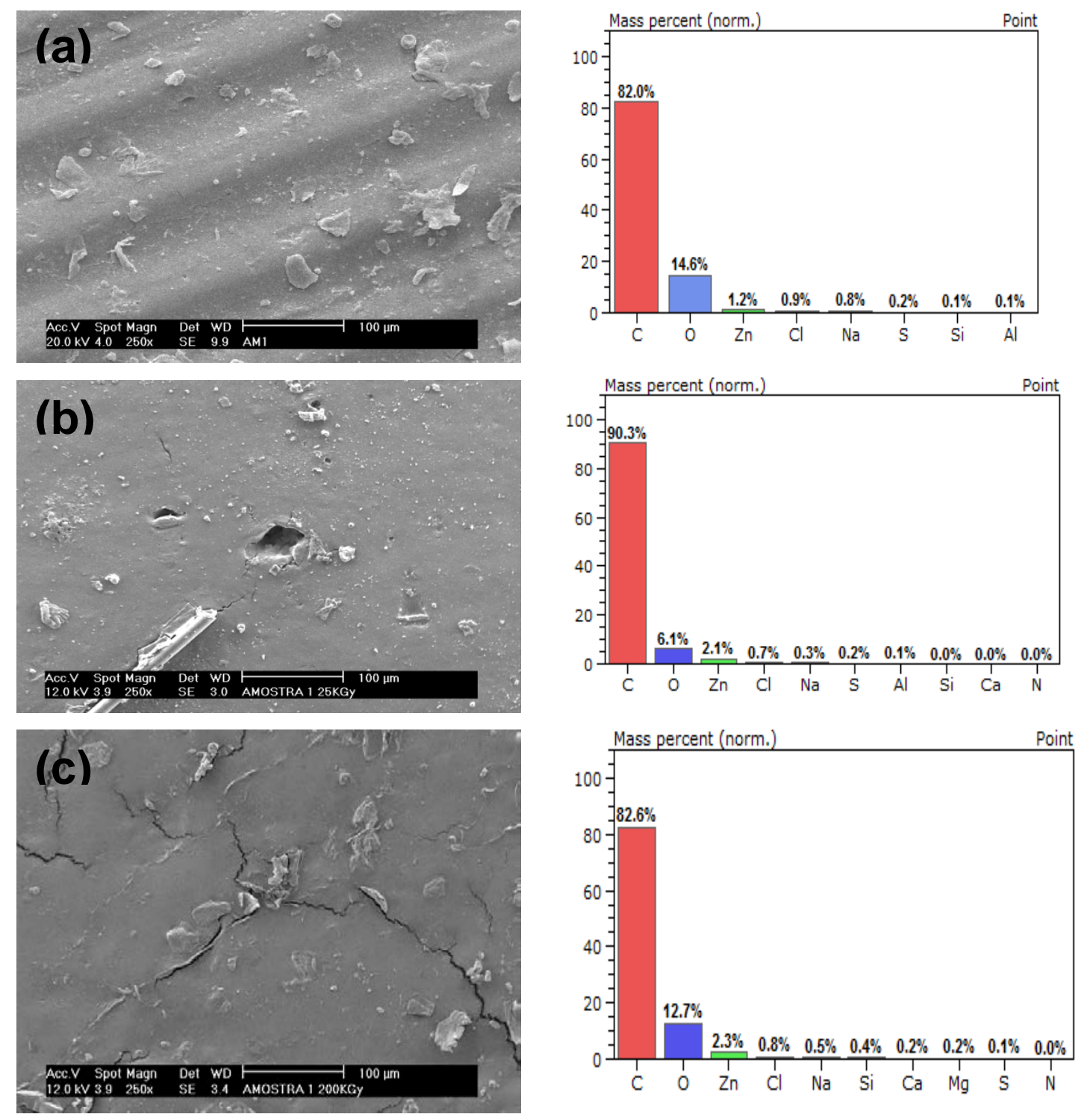

FIGURA 76: Micrografias e resultados de EDS da superfície de ruptura do composto de borracha butílica curado com resina (amostra 1) sem irradiar (a) e irradiada nas doses de 25 kGy (b) e 200 kGy (c). 

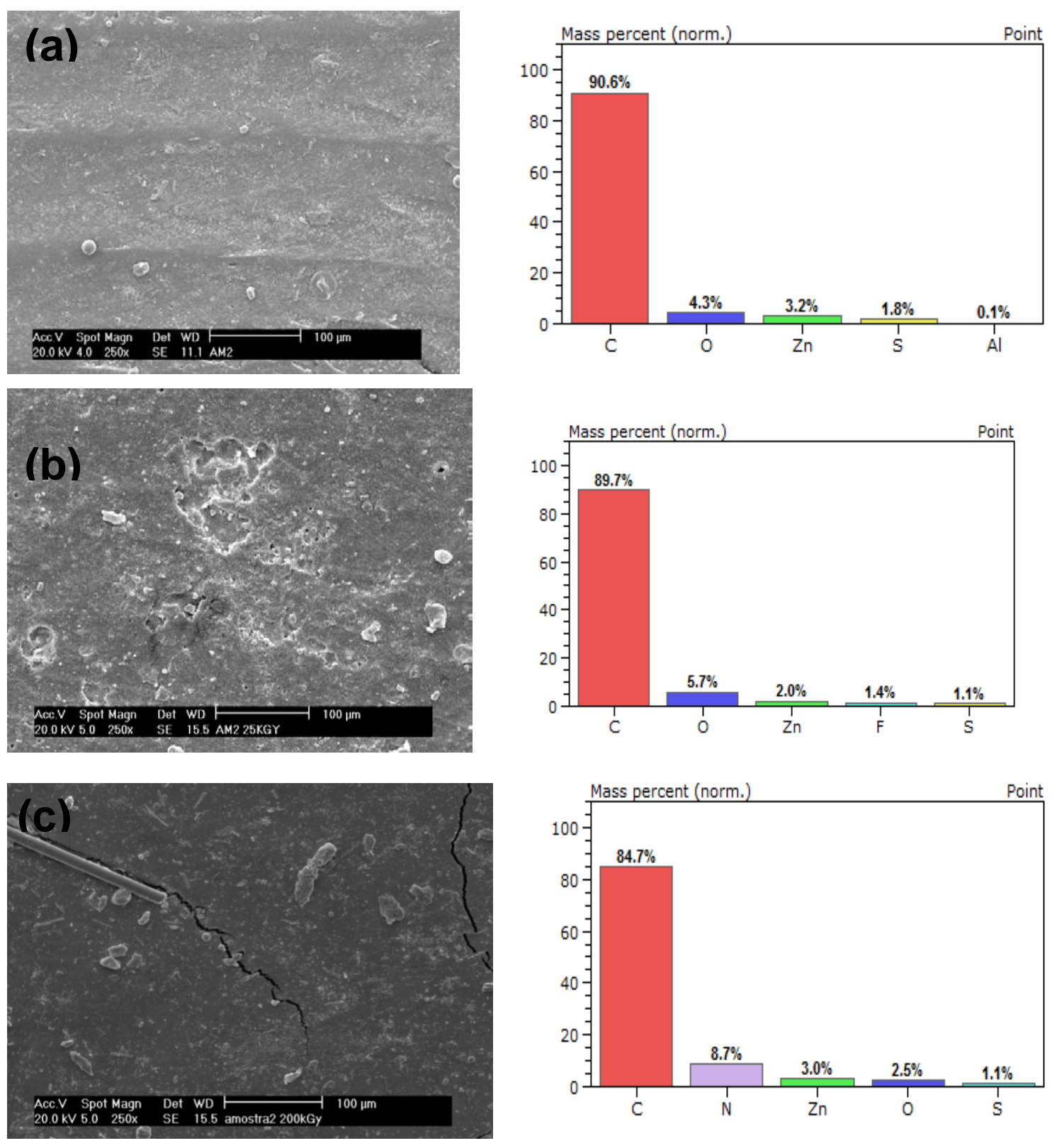

FIGURA 77: Micrografias e resultados de EDS da superfície de ruptura do composto de borracha butílica curado com enxofre (amostra 2) sem irradiar (a) e irradiada nas doses de 25 kGy (b) e 200 kGy (c). 

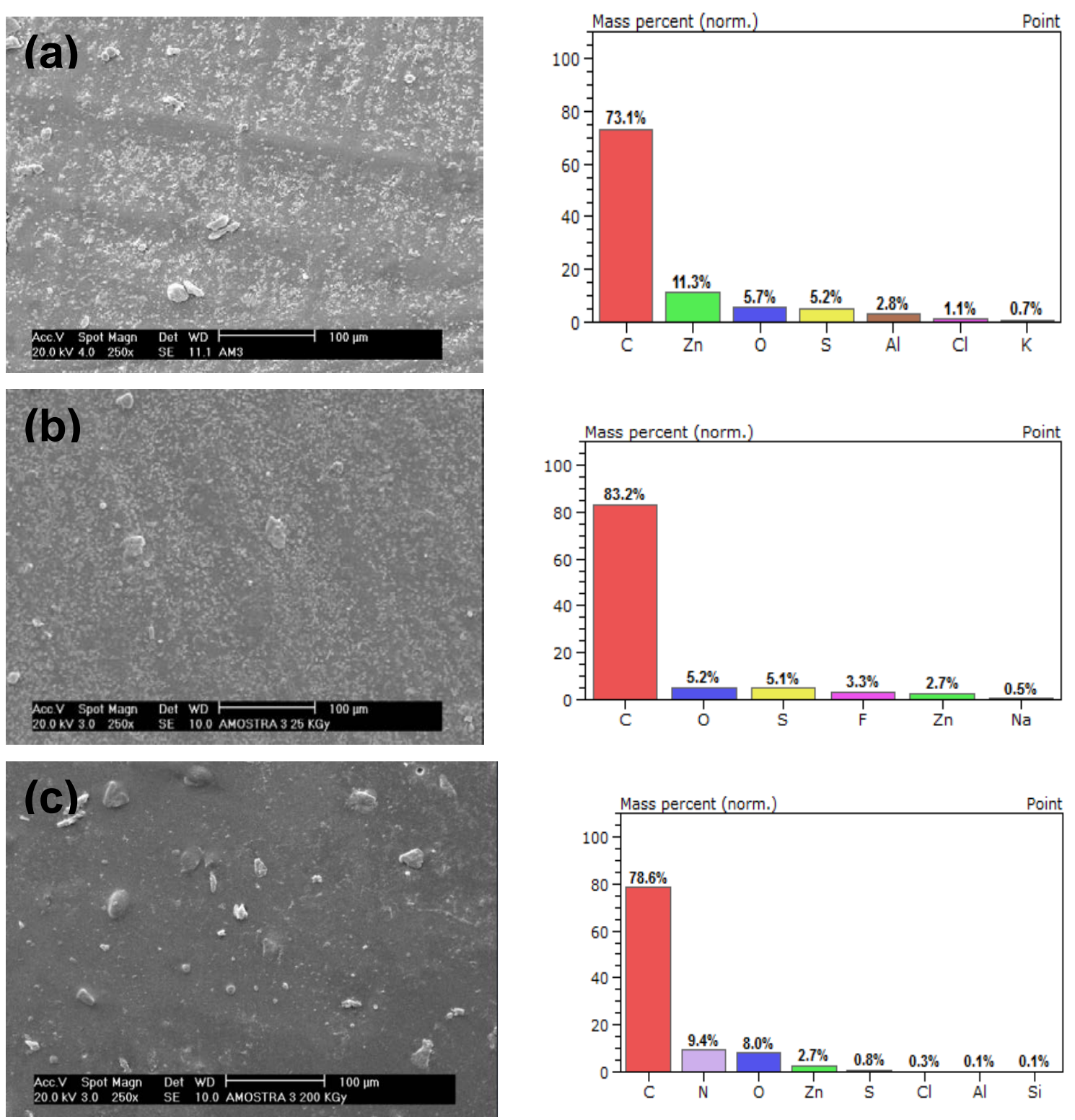

FIGURA 78: Micrografias e resultados de EDS da superfície de ruptura do composto de borracha butílica curado com doador de enxofre (amostra 3) sem irradiar (a) e irradiada nas doses de 25 kGy (b) e 200 kGy (c).

As micrografias e resultados de EDS das amostras de borracha bromobutílica curadas com resina (amostra 4), enxofre (amostra 5) e doador de enxofre (amostra 6), são mostrados nas FIG. 79, 80 e 81. 

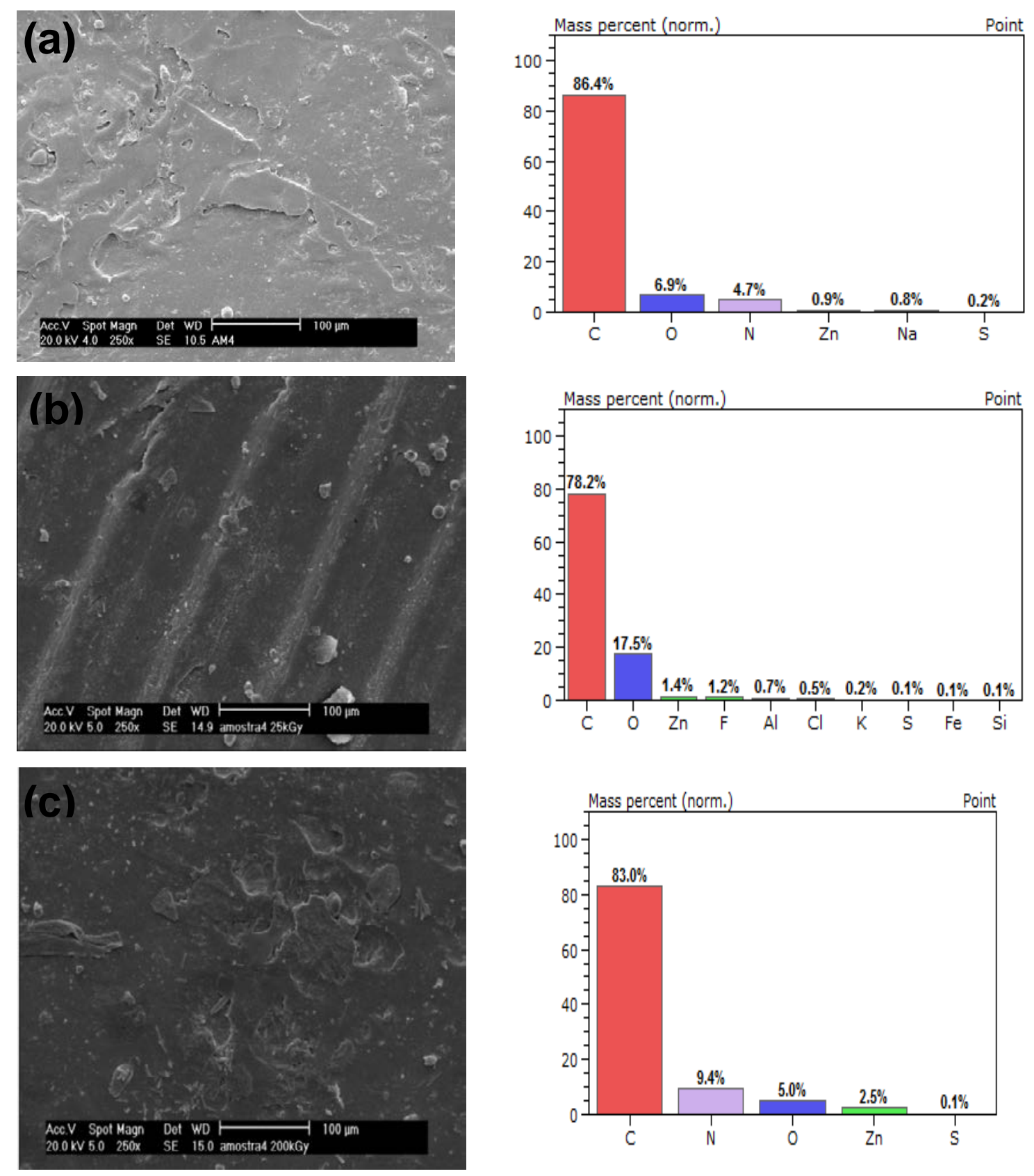

FIGURA 79: Micrografias e resultados de EDS da superfície de ruptura dos cimpostos de borracha bromobutílica curado com resina (amostra 4) sem irradiar (a) e irradiada nas doses de 25 kGy (b) e 200 kGy (c). 

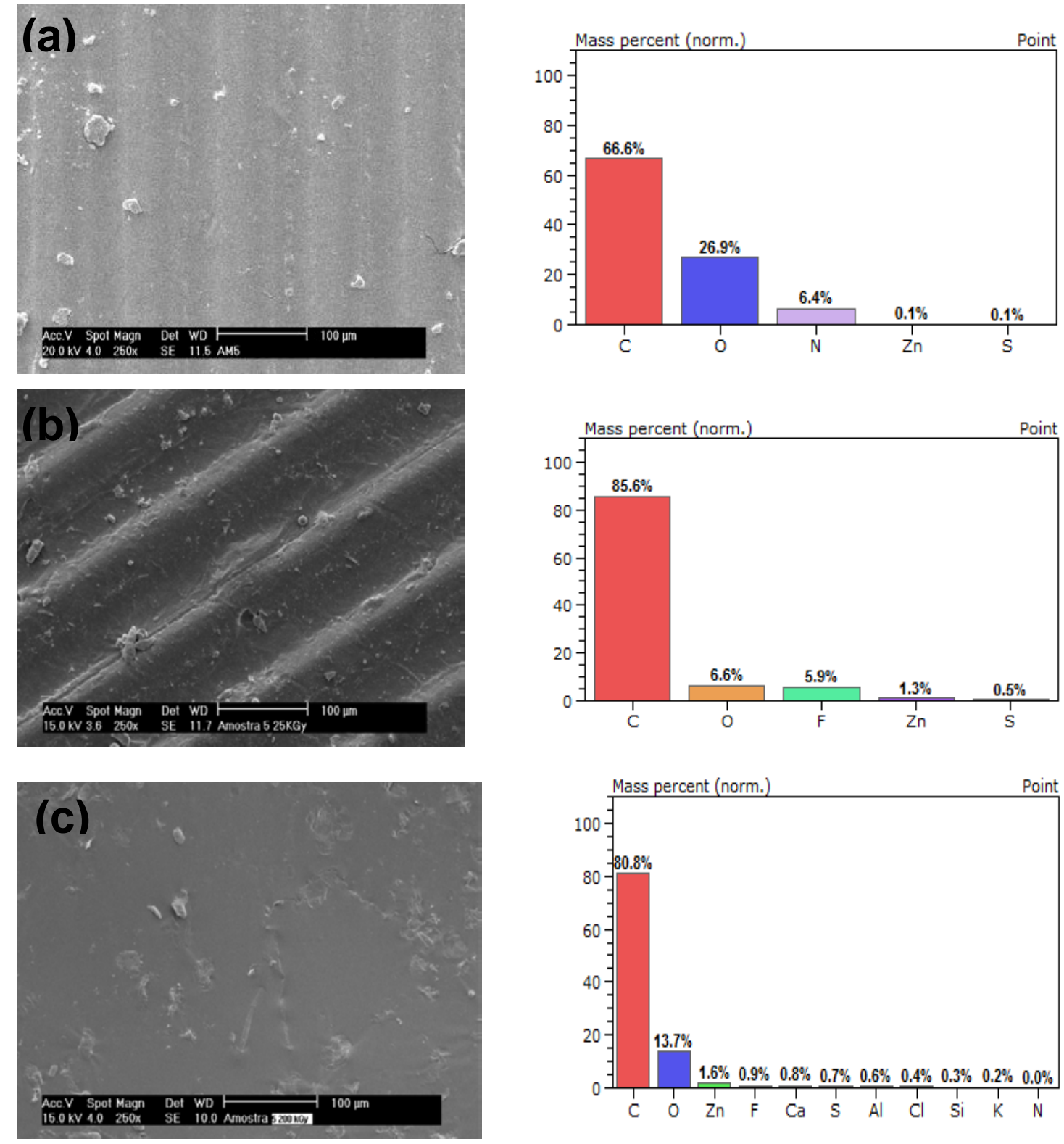

FIGURA 80: Micrografias e resultados de EDS da superfície de ruptura do composto de borracha bromobutílica curada com enxofre (amostra 5) sem irradiar (a) e irradiada nas doses de 25 kGy (b) e 200 kGy (c). 

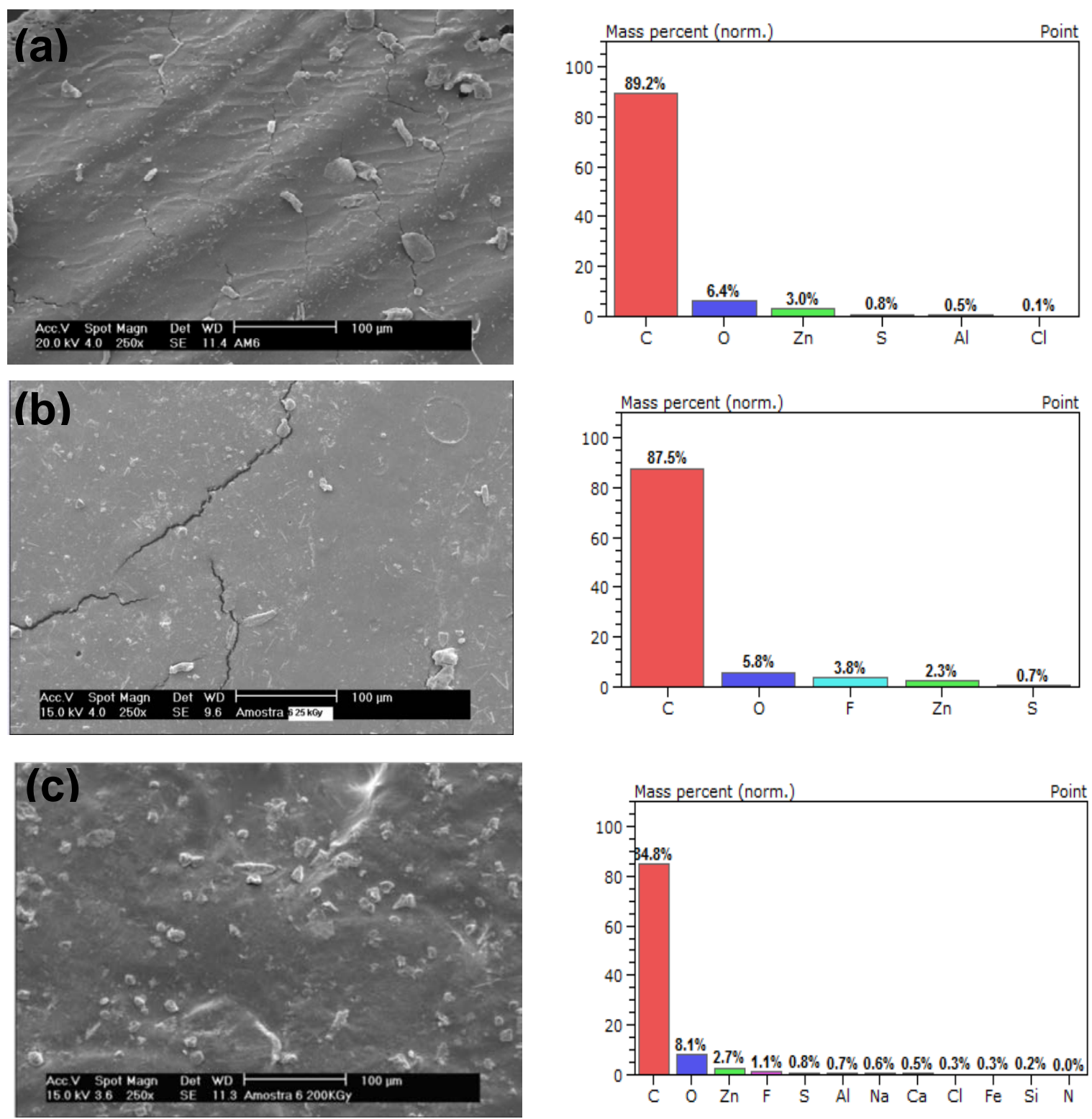

FIGURA 81: Micrografias e resultados de EDS da superfície de ruptura do composto de borracha bromobutílica curada com doador de enxofre (amostra 6) sem irradiar (a) e irradiada nas doses de 25 kGy (b) e 200 kGy (c).

As micrografias e resultados de EDS das amostras de borracha clorobutílica curadas com resina (amostra 7), enxofre (amostra 8) e doador de enxofre (amostra 9), são mostrados nas FIG. 82, 83 e 84. 

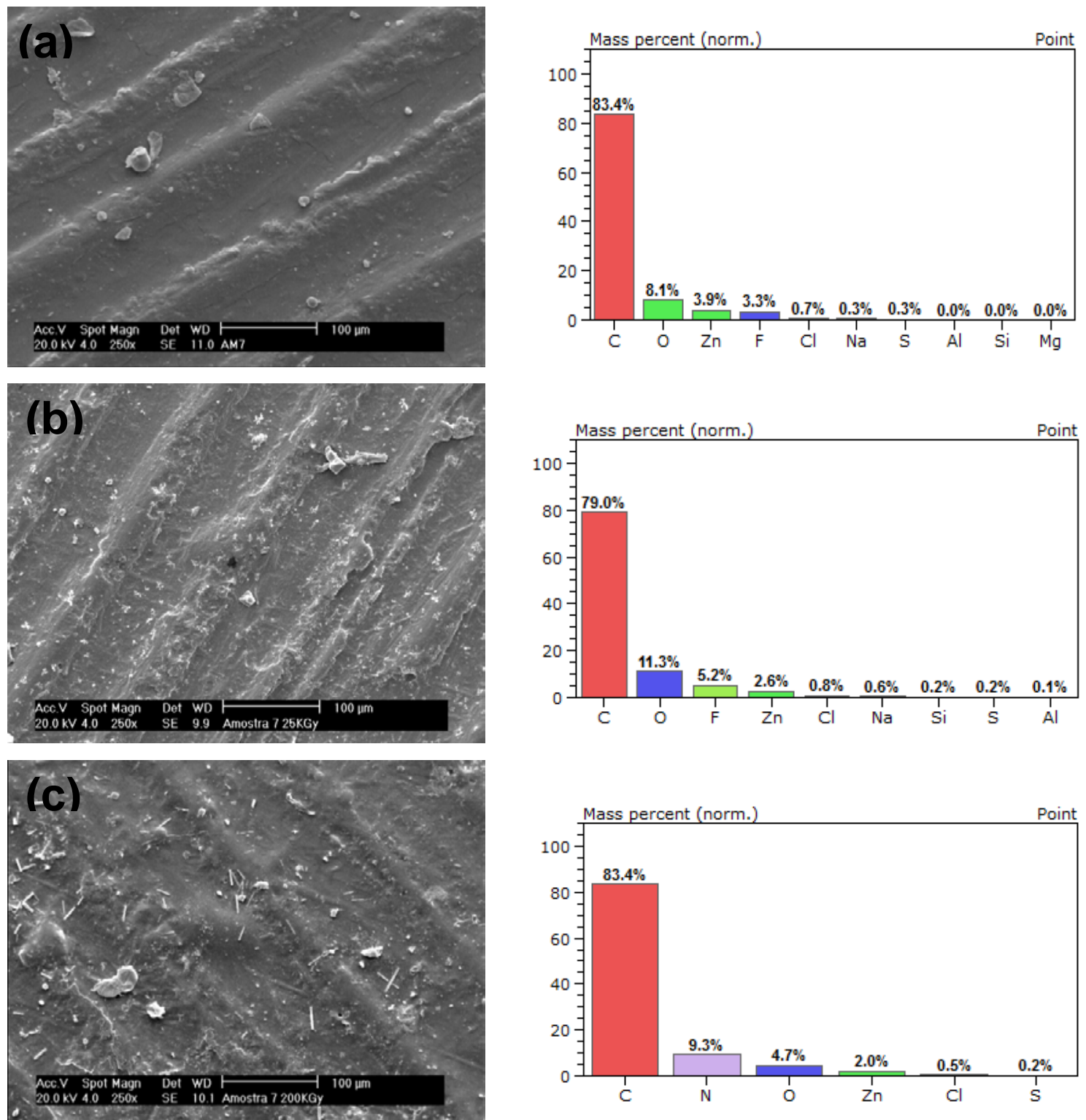

FIGURA 82: Micrografias e resultados de EDS da superfície de ruptura do composto de borracha clorobutílica curado com resina (amostra 7) sem irradiar (a) e irradiado nas doses de 25 kGy (b) e 200 kGy (c). 

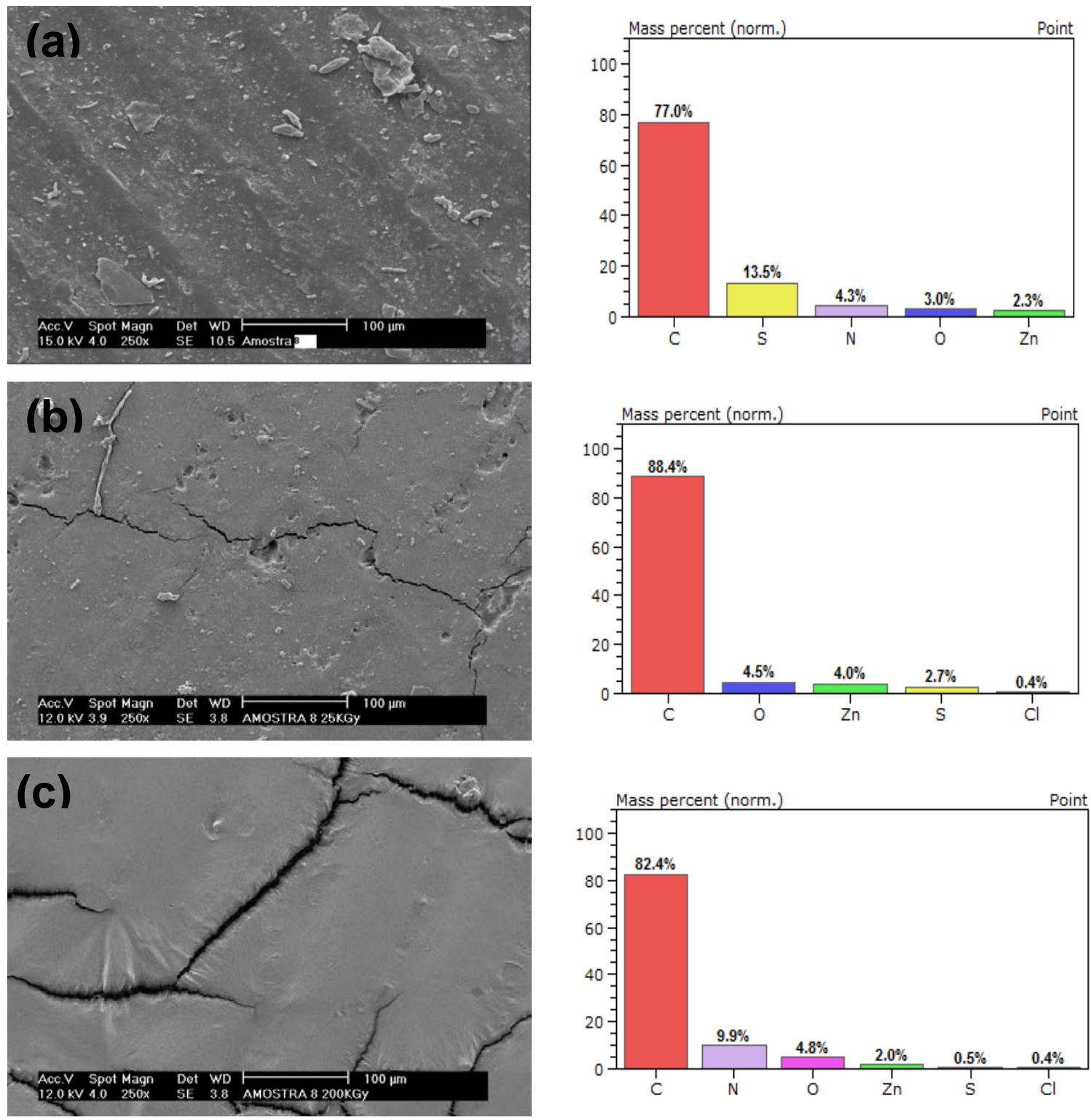

FIGURA 83: Micrografias e resultados de EDS da superfície de ruptura do composto de borracha clorobutílica curado com enxofre (amostra 8) sem irradiar (a) e irradiado nas doses de 25 kGy (b) e 200 kGy (c). 

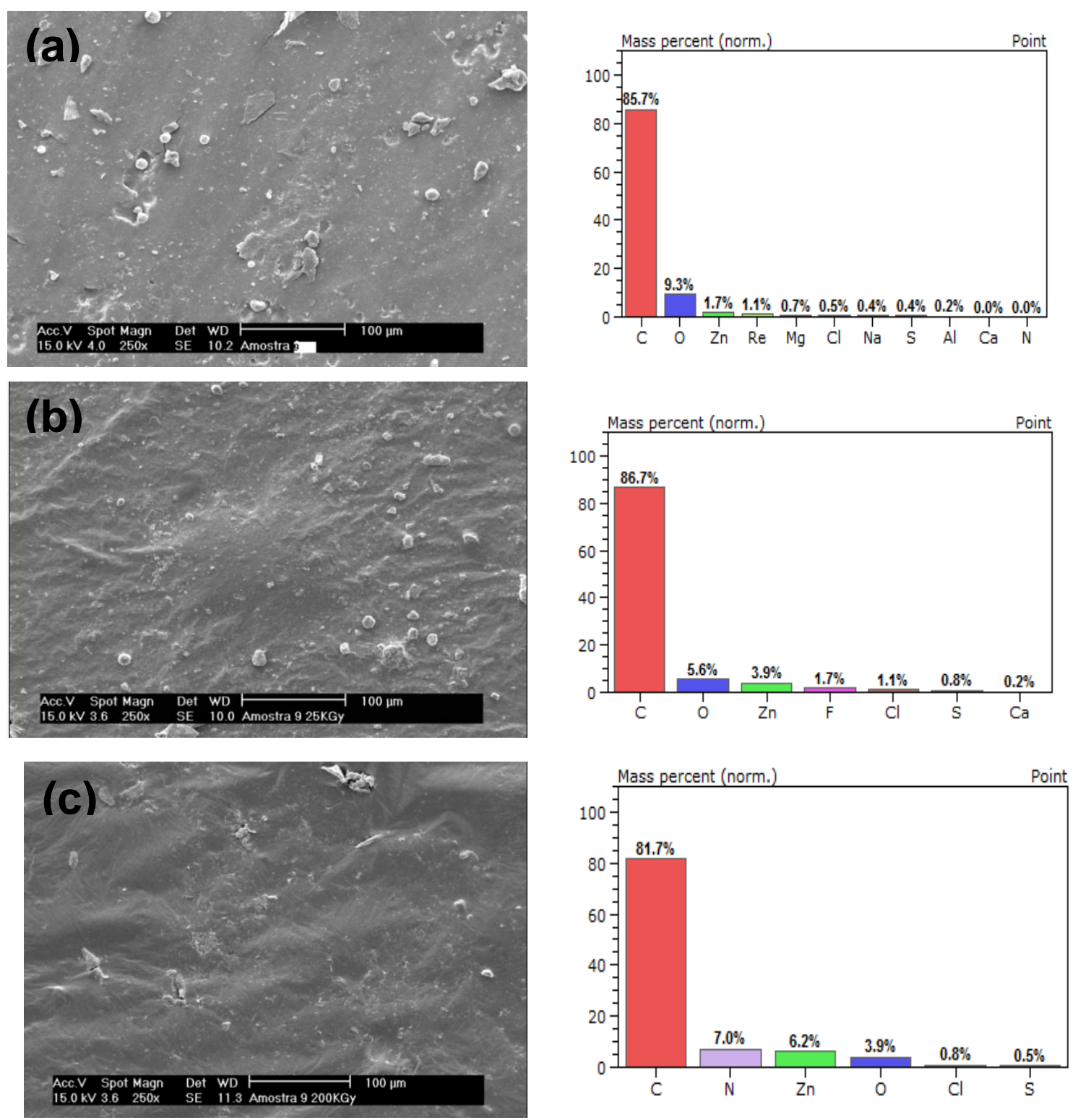

FIGURA 84: Micrografias e resultados de EDS da superfície de ruptura do composto de borracha clorobutílica curado com doador de enxofre (amostra 9) sem irradiar (a) e irradiado nas doses de 25 kGy (b) e 200 kGy (c).

Pode ser observado a partir das micrografias com aumento de 250 vezes da superfície de ruptura das borrachas butílicas, bromobutílica e clorobutílicas curadas com resina (amostras 1, 4 e 7), enxofre (amostras 2, 5 e 8) e doador de enxofre (amostra 3, 6 e 9), uma diminuição de partículas dispersas com o aumento da dose, sugerindo melhor compatibilização de eventuais partículas ou aglomerados. Em várias amostras também aparecem fissuras com a 
dose denotando um material mais frágil e quebradiço evidenciando a degradação (cisão e reticulação) da borracha e sugerindo oxidação elevada. A acumulação de efeitos (fratura, porosidade, rachaduras e etc.) e danos induzidos pela radiação conduz a uma falha no interior da borracha que corresponde a uma transição do comportamento elástico para um comportamento frágil ${ }^{144}$. A radiação pode transformar as amostras flexíveis em rígidas e quebradiças especialmente quando doses elevadas são aplicadas.

As análises de EDS mostraram nas amostras 2 (butílica curada com enxofre), 3 (butílica curada com doador de enxofre) e amostra 8 (clorobutílica curada com enxofre), a existência de grande quantidade de enxofre na superfície da borracha antes da irradiação, provavelmente por excesso ou má incorporação do material, fazendo com que o enxofre exsude para a superfície da fratura do composto. Com o início da radiação, se observa o consumo de enxofre sugerindo oxidação e volatização do enxofre $\left(\mathrm{SO}_{\mathrm{x}}\right)$.

Verifica-se também que o teor de oxigênio varia bastante com a dose irradiada, não existindo uma tendência definida. Uma possível explicação para esse fato, é que se trata de micrografia da fratura e o oxigênio não penetra no interior da amostra durante a irradiação, tendo em vista as excepcionais propriedades de barreira das borrachas butílicas. Portanto a oxidação deve ocorrer na etapas de processamento da borracha.

Os elementos químicos tais como: Alumínio (Al), Cálcio (Ca) e etc., presentes nas análises de EDS de algumas amostras não fazem parte das formulações das borrachas. Podem ser atribuídos, a algum tipo de contaminação ocorrida durante a mistura das composições. O Nitrogênio ( $N$ ) presente pode ser proveniente da geração de diversos tipos de nitrosaminas, por parte de alguns aceleradores de vulcanização como os tiurans (TMTM, TMTD) e alguns ditiocarbamatos (ZBDC, ZMDC, ZBEC). 


\subsubsection{Microscopia Eletrônica de Varredura (MEV) com EDS dos compostos de borracha butílica e halobutílica irradiadas e cisalhadas}

As micrografias e o EDS realizados na superfície de ruptura dos compostos de borracha butílica curados com resina (amostra 1), enxofre (amostra 2) e doador de enxofre (amostra 3) irradiados nas doses de 25 kGy e 200 kGy e cisalhados, estão apresentadas nas FIG. 85, 86 e 87 respectivamente.
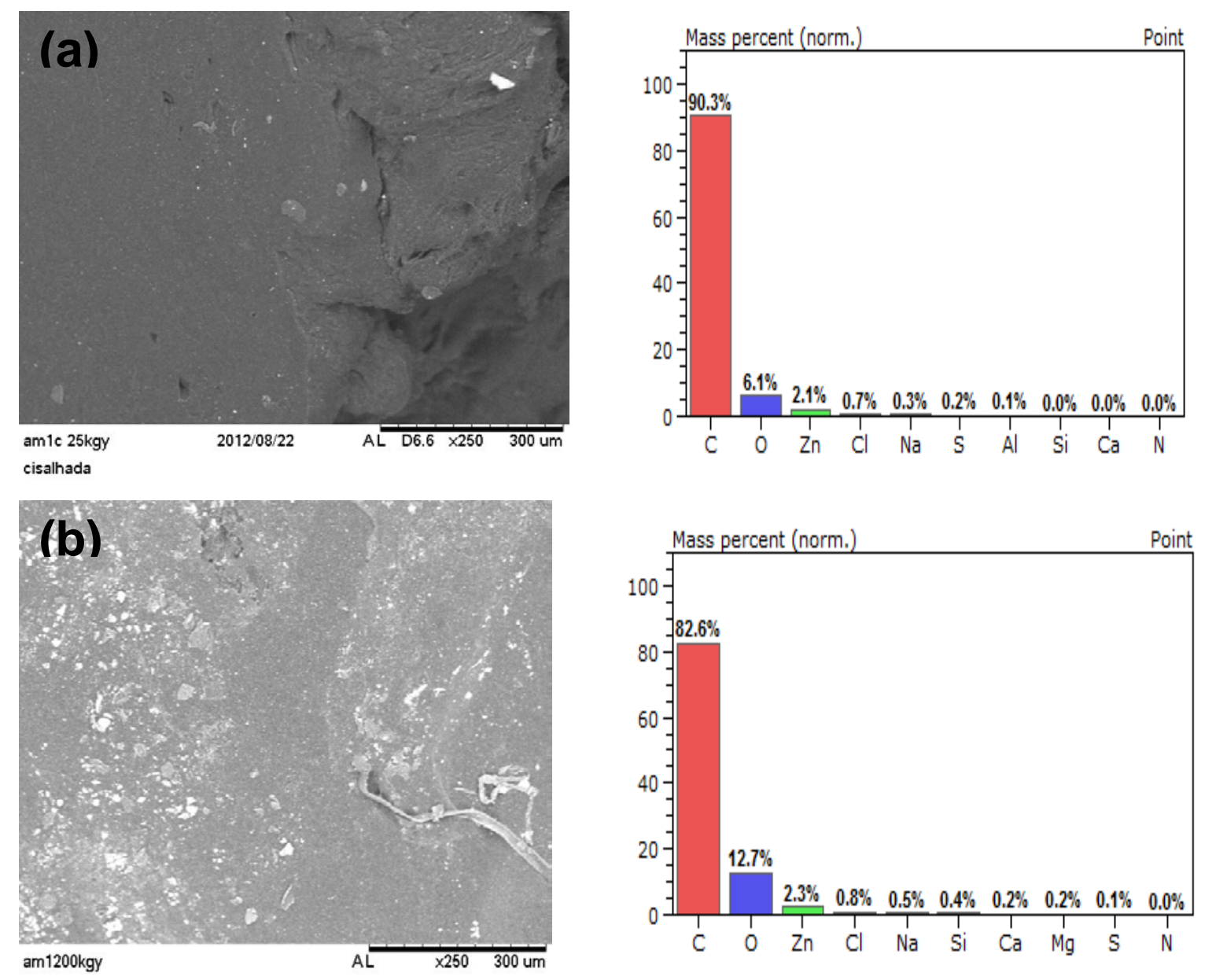

FIGURA 85: Micrografias e resultados de EDS da superfície de ruptura do composto de borracha butílica curada com resina (amostra 1) irradiada nas doses de (a) 25 kGy e (b) 200 kGy e cisalhadas. 

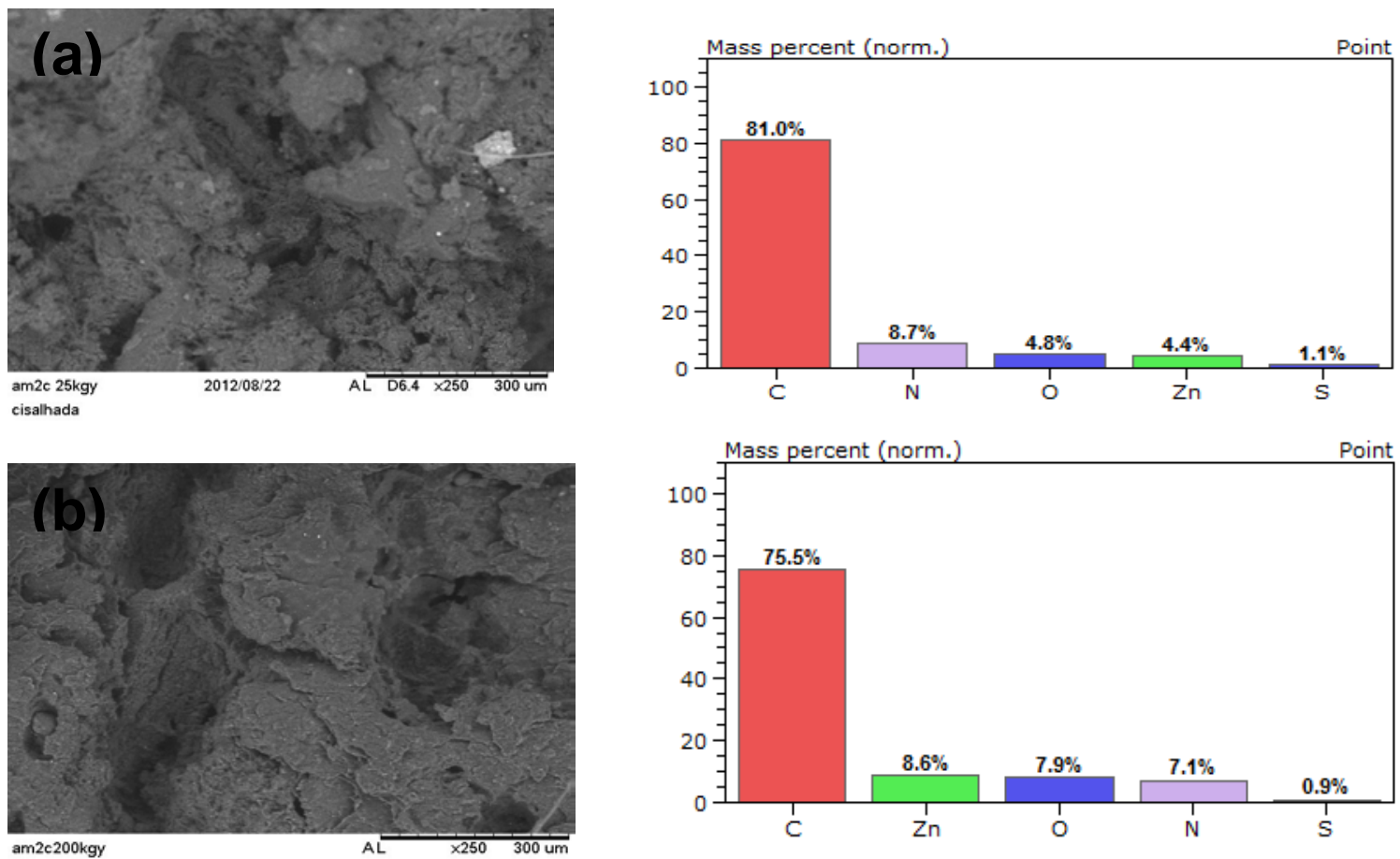

FIGURA 86: Micrografias e resultados de EDS da superfície de ruptura do composto de borracha butílica curada com enxofre (amostra 2) irradiada nas doses de 25 kGy e 200 kGy e cisalhadas.
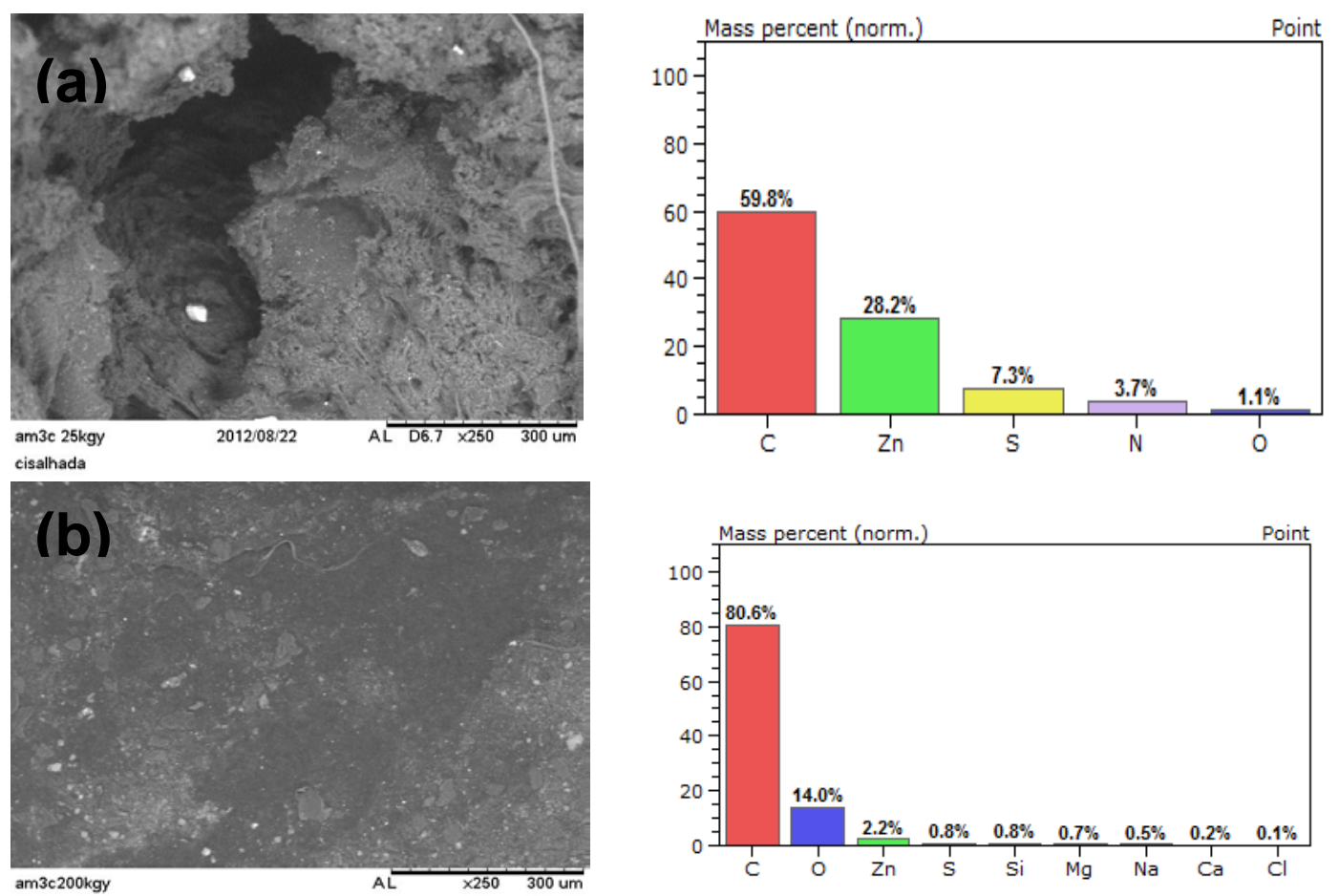

FIGURA 87: Micrografias e resultados de EDS da superfície de ruptura do composto de borracha butílica curada com doador de enxofre (amostra 3) irradiada nas doses de (a) 25 kGy e (b) 200 kGy e cisalhadas. 
A partir das micrografias das amostras 1, 2 e 3 (curadas com resina, enxofre e doador de enxofre) observou-se que as amostras curadas com enxofre e doador de enxofre (amostra 2 e 3), irradiadas e cisalhadas apresentam grande rugosidade na superfície de ruptura na dose de 25 kGy, explicando o decréscimo das propriedades mecânicas desses compostos irradiados e cisalhados. Verificase que, mesmo após o intenso cisalhamento os compostos ainda apresentam elevado conteúdo de aglomerados, indicando gelificação heterogênea ou zonas de reticulação. Para dose de 200 kGy, verifica-se uma superfície mais lisa e pegajosa, indicando cisão da molécula da borracha. A análise EDS, também comprova este fato, uma vez que a quantidade de enxofre é consumida com o aumento da dose com provável produção de SOx e sugerindo que as pontes sulfídicas possam proteger o polímero da oxidação.

As micrografias e resultados de EDS das amostras de borracha bromobutílicas curadas com resina (amostra 4), enxofre (amostra 5) e doador de enxofre (amostra 6), irradiadas nas doses de 25 kGy e 200 kGy e cisalhadas, são mostrados nas FIG. 88, 89 e 90.
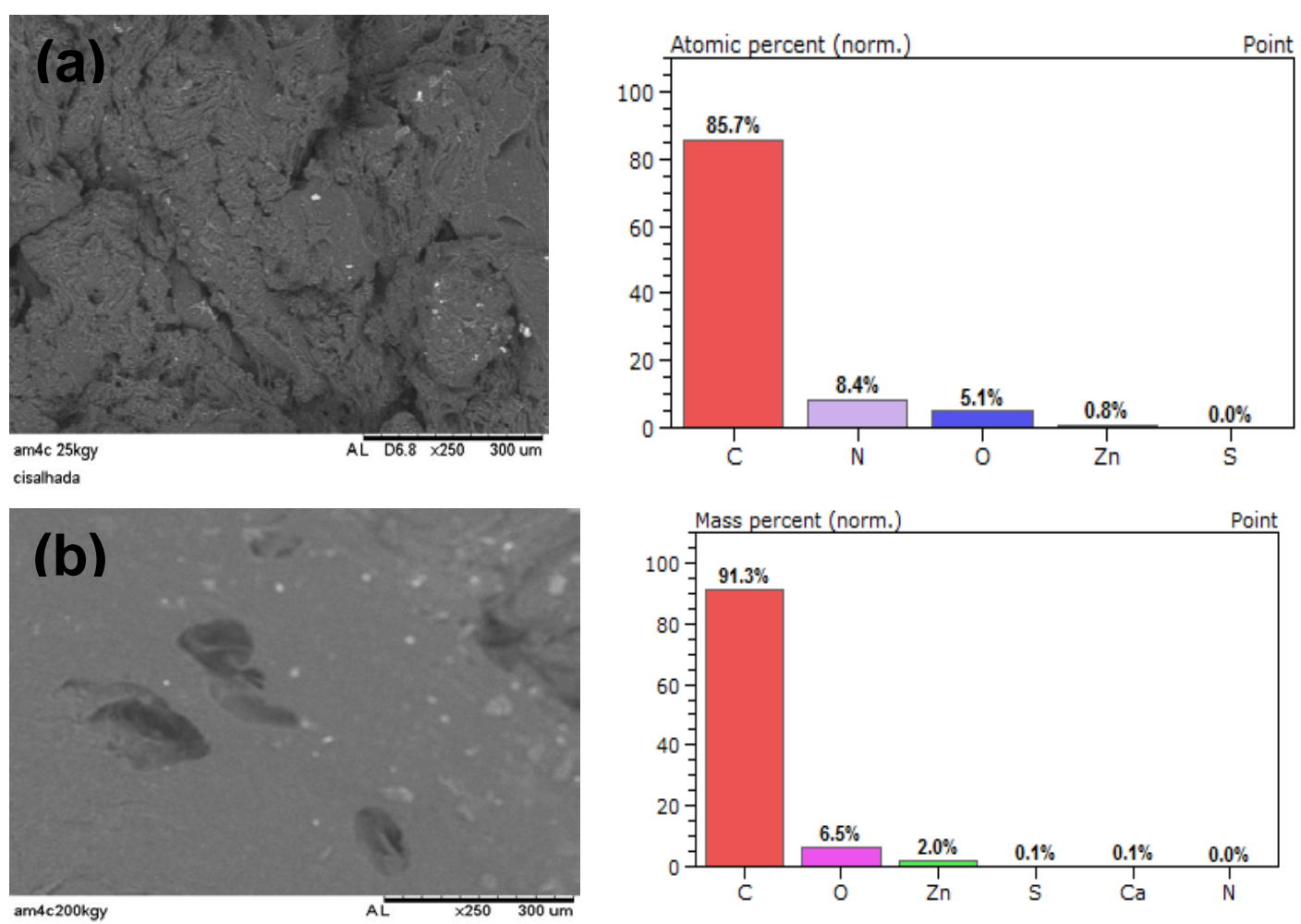

FIGURA 88: Micrografias e resultados de EDS da superfície de ruptura do composto de borracha bromobutílica curada com resina (amostra 4) irradiada nas doses de (a) 25 kGy e (b) 200 kGy e cisalhadas. 

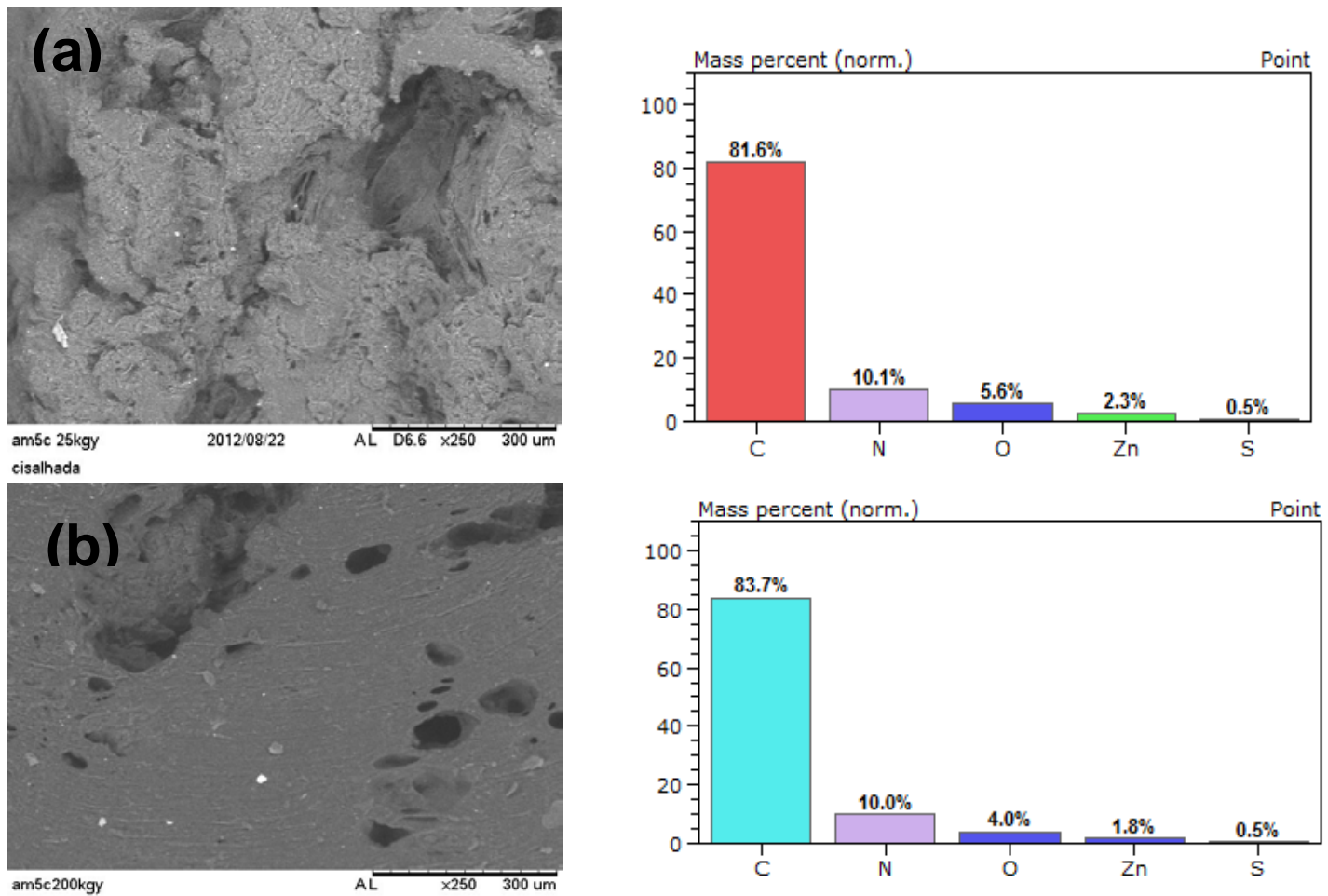

FIGURA 89: Micrografias e resultados de EDS da superfície de ruptura do composto de borracha bromobutílica curado com enxofre (amostra 5) irradiada nas doses de (a) 25 kGy e (b) 200 kGy e cisalhadas.
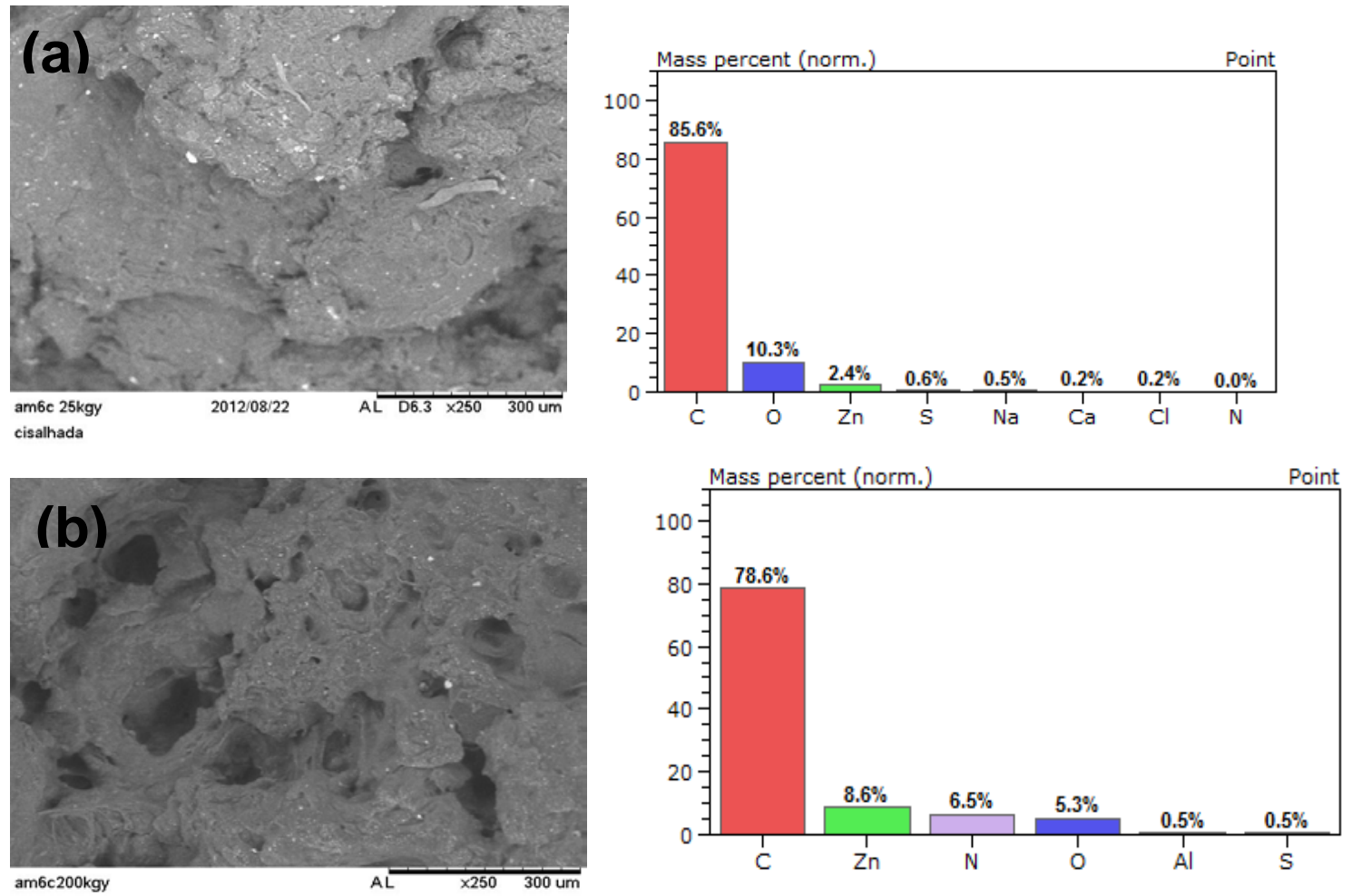

FIGURA 90: Micrografias e resultados de EDS da superfície de ruptura do composto de borracha bromobutílica curado com doador de enxofre (amostra 6) irradiada nas doses de (a) 25 kGy e (b) 200 kGy e cisalhadas. 
As micrografia das amostras 4, 5 e 6 (curadas com resina, enxofre e doador de enxofre respectivamente), mostraram rugosidade na superfície de ruptura para doses de $25 \mathrm{kGy}$ seguida de cisalhamento, indicando alguns pontos de reticulação. Na dose de 200 kGy a superfície de ruptura do material, apresenta aparência menos rugosa, porém com muita porosidade sugerindo a ocorrência de reticulação heterogênea que produz gelificação localizada na borracha.

A porosidade apresentada nas micrografias das amostras irradiadas e cisalhadas, provavelmente é a responsável pelo decréscimo abrupto de valores de tensão e alongamento na ruptura quando comparados com os resultados das amostras somente irradiadas.

As FIG 91, 92 e 93 apresentam os resultados das micrografias e resultados de EDS das amostras de borracha clorobutílicas curadas com resina (amostra 7), enxofre (amostra 8) e doador de enxofre (amostra 9).
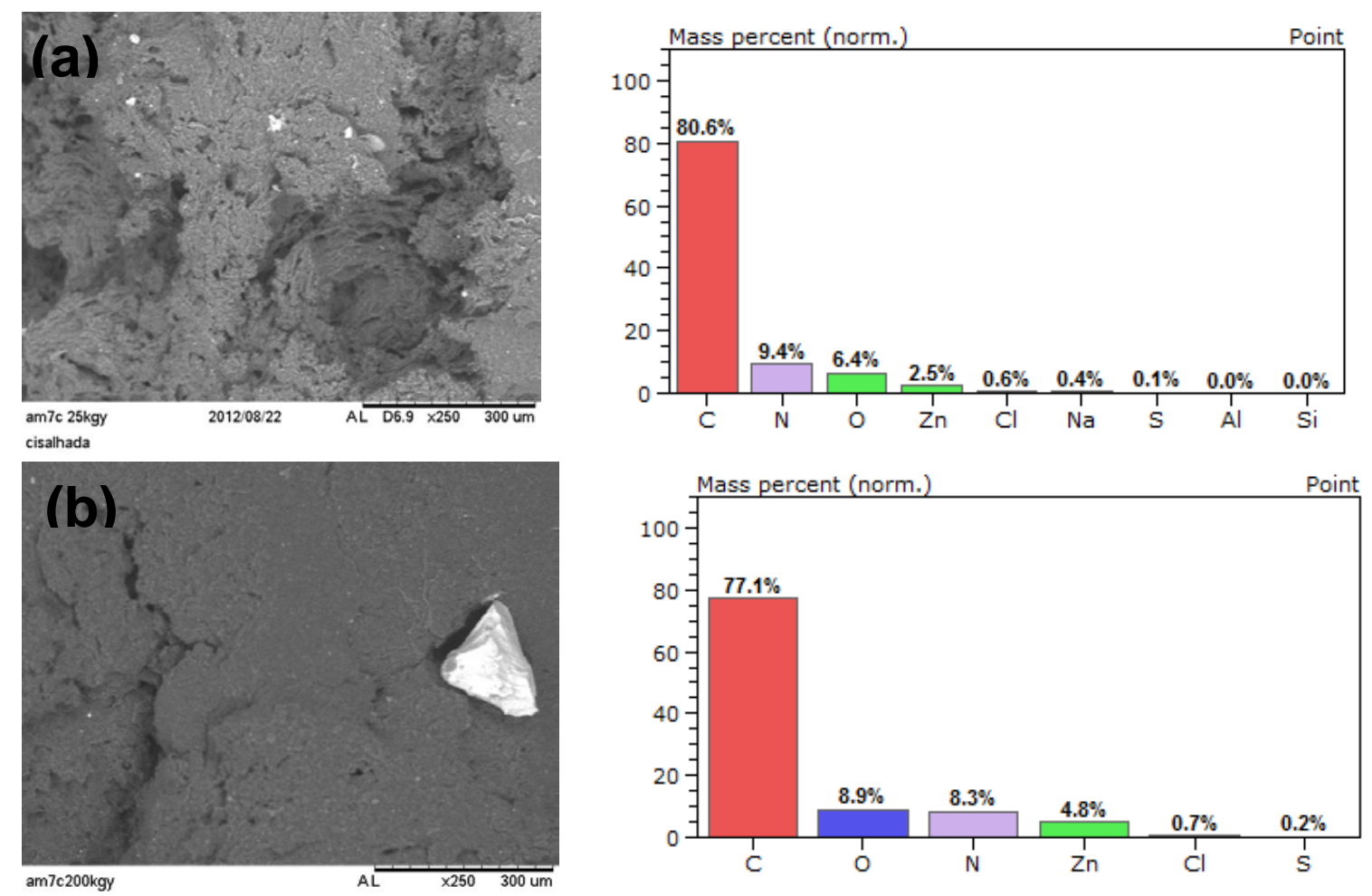

FIGURA 91: Micrografias e resultados de EDS da superfície de ruptura do composto de borracha clorobutílica curada com resina (amostra 7) irradiada nas doses de (a) 25 kGy e (b) 200 kGy e cisalhadas. 

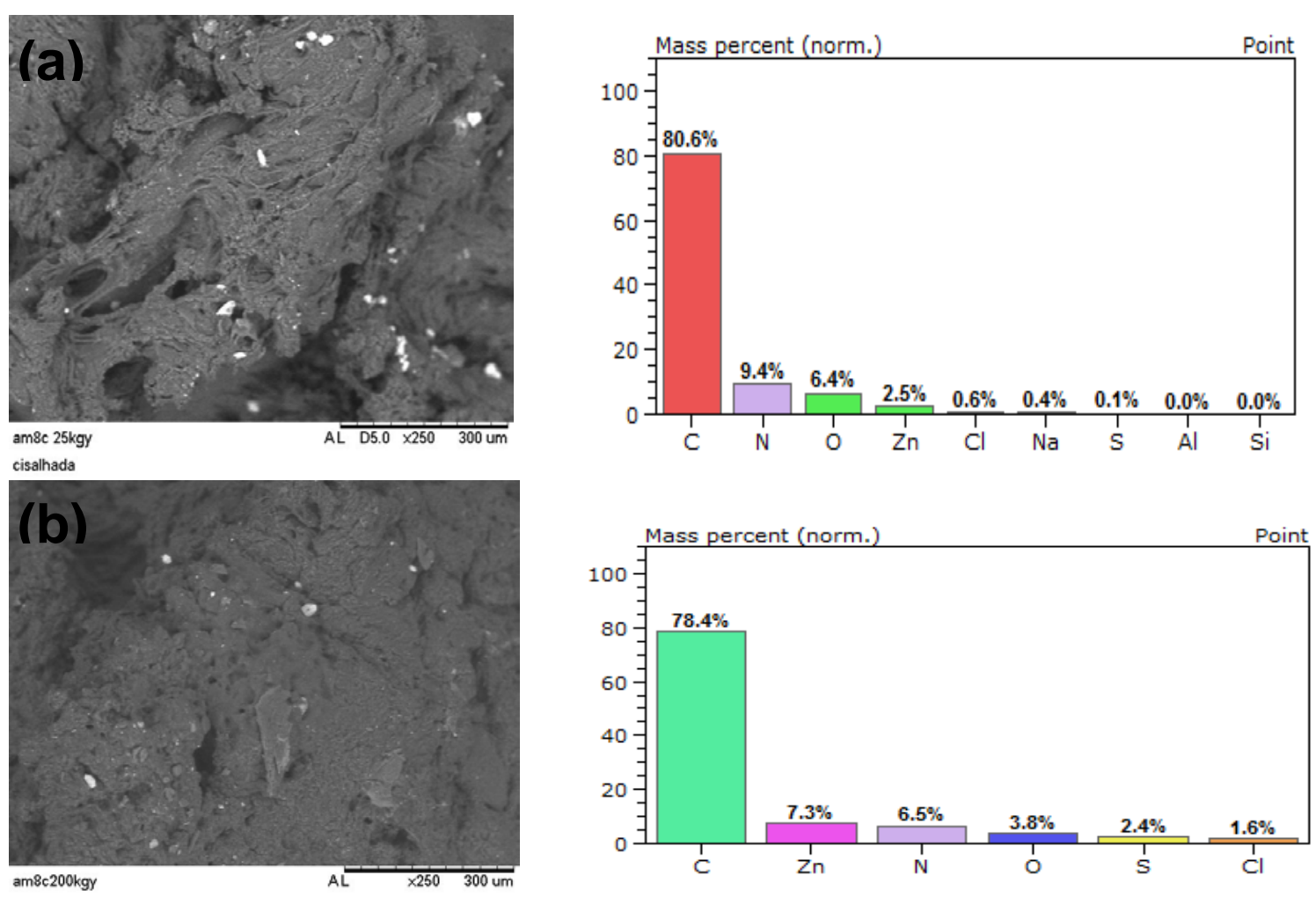

FIGURA 92: Micrografias e resultados de EDS da superfície de ruptura do composto de borracha clorobutílica curado com enxofre (amostra 8) irradiada nas doses de (a) 25 kGy e (b) 200 kGy e cisalhadas.
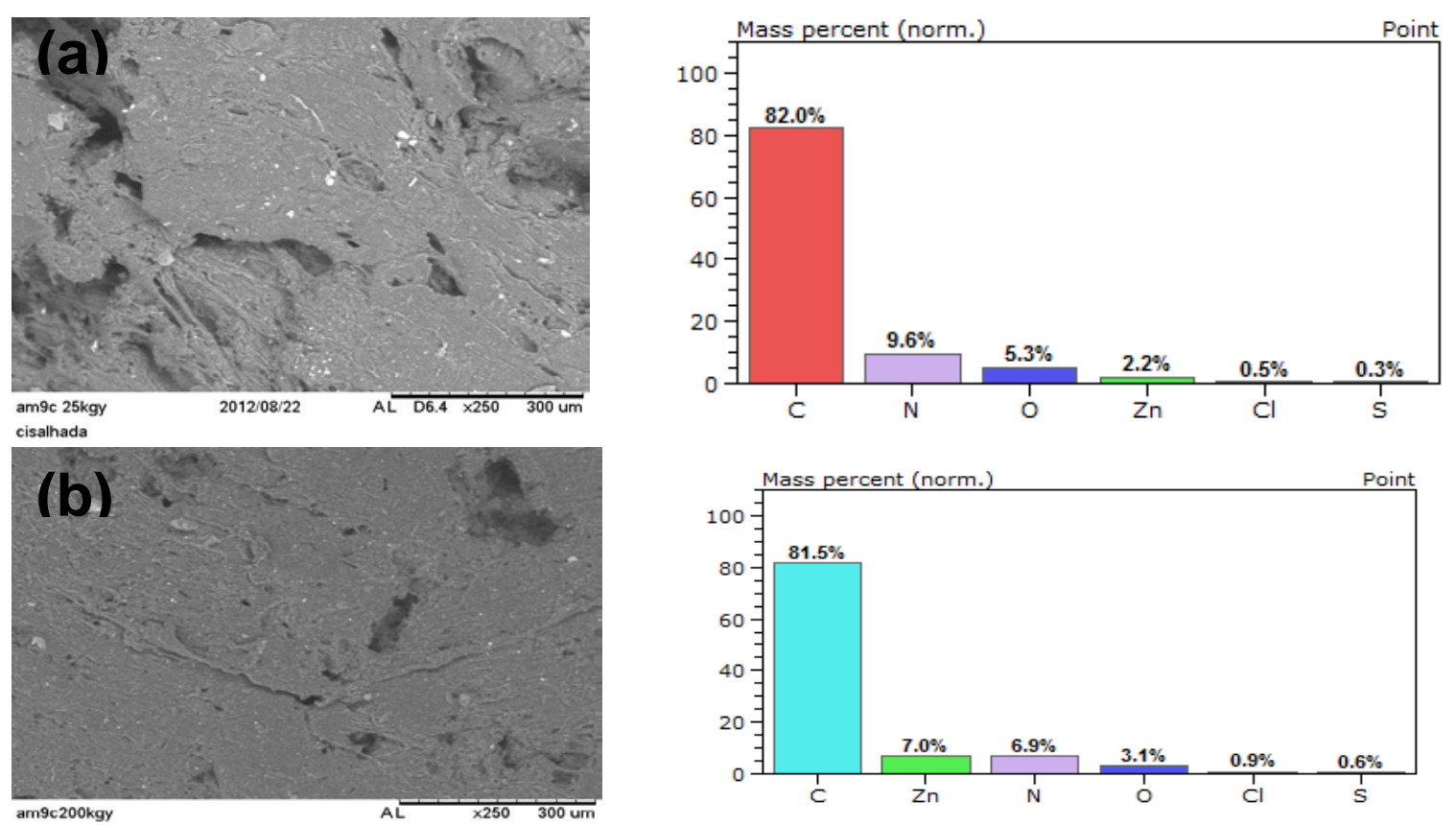

FIGURA 93: Micrografias e resultados de EDS da superfície de ruptura do composto de borracha clorobutílica curado com doador de enxofre (amostra 9) irradiada nas doses de (a) 25 kGy e (b) 200 kGy e cisalhadas. 
As micrografias das amostras de borracha clorobutílica curadas com resina, enxofre e doador de enxofre (amostras 7, 8 e 9) apresentaram superfície de ruptura rugosa, indicando a existência de alguns pontos de aglomeração (reticulação), mesmo após o cisalhamento intenso.

As análises de EDS revelaram a presença de enxofre na superfície de ruptura das amostras irradiadas e cisalhadas, A explicação para elevada quantidade de nitrogênio é a geração de nitrosaminas por parte de alguns aceleradores de vulcanização. 


\subsection{Propriedades dos Reciclados}

A TAB 19 mostra a nomenclatura utilizada para identificação das amostras contendo borracha recuperada e borracha virgem. Os compostos contendo borrachas irradiadas a 25 kGy e cisalhadas - são as borrachas recuperadas, foram nomeados com a sigla RC. Os compostos contendo $100 \%$ de borracha virgem foram designados com a sigla $A M$ e a numeração refere-se à formulação do composto.

TABELA 19: Nomenclatura das amostras com 100\% de borracha virgem (AM) e das amostras contendo $30 \mathrm{phr}$ de borracha recuperada (RC).

\begin{tabular}{|c|c|}
\hline $\begin{array}{l}\mathrm{RC} 1 \text { = formulação de borracha butílica com } \\
\text { borracha butílica recuperada curada com } \\
\text { resina. }\end{array}$ & $\begin{array}{l}\text { AM } 1 \text { = formulação com } 100 \% \text { de } \\
\text { borracha butílica curada com } \\
\text { resina. }\end{array}$ \\
\hline $\begin{array}{l}\text { RC } 2 \text { = formulação de borracha butílica com } \\
\text { borracha butílica recuperada curada com } \\
\text { enxofre. }\end{array}$ & $\begin{array}{l}\text { AM } 2 \text { = formulação com } 100 \% \text { de } \\
\text { borracha butílica curada com } \\
\text { enxofre. }\end{array}$ \\
\hline $\begin{array}{l}\text { RC } 3 \text { = formulação de borracha butílica com } \\
\text { borracha butílica recuperada curada com } \\
\text { doador de enxofre. }\end{array}$ & $\begin{array}{l}\text { AM } 3 \text { = formulação com } 100 \% \text { de } \\
\text { borracha butílica curada com } \\
\text { doador de enxofre. }\end{array}$ \\
\hline $\begin{array}{l}\text { RC } 4 \text { = formulação de borracha } \\
\text { bromobutílica com borracha bromobutílica } \\
\text { recuperada curada com resina. }\end{array}$ & $\begin{array}{l}\text { AM } 4 \text { = formulação com } 100 \% \text { de } \\
\text { borracha bromobutílica curada com } \\
\text { resina. }\end{array}$ \\
\hline $\begin{array}{l}\text { RC } 5 \text { = formulação de borracha } \\
\text { bromobutílica com borracha bromobutílica } \\
\text { recuperada curada com enxofre. }\end{array}$ & $\begin{array}{l}\text { AM } 5 \text { formulação com } 100 \% \text { de } \\
\text { borracha bromobutílica curada com } \\
\text { enxofre. }\end{array}$ \\
\hline $\begin{array}{l}\text { RC } 6 \text { = formulação de borracha } \\
\text { bromobutílica com borracha bromobutílica } \\
\text { recuperada curada com doador de enxofre. }\end{array}$ & $\begin{array}{l}\text { AM } 6 \text { = formulação com } 100 \% \text { de } \\
\text { borracha bromobutílica curada com } \\
\text { doador de enxofre. }\end{array}$ \\
\hline $\begin{array}{l}\text { RC } 7 \text { = formulação de borracha clorobutílica } \\
\text { com borracha clorobutílica recuperada } \\
\text { curada com resina. }\end{array}$ & $\begin{array}{l}\text { AM } 7 \text { = formulação com } 100 \% \text { de } \\
\text { borracha clorobutílica curada com } \\
\text { resina. }\end{array}$ \\
\hline $\begin{array}{l}\text { RC } 8 \text { = formulação de borracha clorobutílica } \\
\text { com borracha clorobutílica recuperada } \\
\text { curada com enxofre. }\end{array}$ & $\begin{array}{l}\text { AM } 8 \text { = formulação com } 100 \% \text { de } \\
\text { borracha clorobutílica curada com } \\
\text { enxofre. }\end{array}$ \\
\hline $\begin{array}{l}\text { RC } 9 \text { = formulação de borracha clorobutílica } \\
\text { com borracha clorobutílica recuperada } \\
\text { curada com doador de enxofre. }\end{array}$ & $\begin{array}{l}\text { AM } 9 \text { = formulação com } 100 \% \text { de } \\
\text { borracha clorobutílica curada com } \\
\text { doador de enxofre. }\end{array}$ \\
\hline
\end{tabular}




\subsubsection{Parâmetros reométricos}

Os parâmetros reométricos para os compostos formulados com borrachas butílicas e halobutílicas recuperadas e compostos formulados com 100\% de borracha virgem butílica e halobutílica, estão apresentados na TAB 20.

O torque mínimo ML está relacionado à viscosidade da composição na temperatura do ensaio, e, dessa forma, é um indicativo da processabilidade ${ }^{153}$. Observa-se que o ML aumenta para as borrachas butílicas e halobutílicas independente do sistema de cura, indicando um ligeiro aumento no tempo de processamento destas misturas.

O torque máximo, $\mathrm{MH}$, está relacionado à formação de ligações cruzadas. Os resultados da TAB 20 para esse parâmetro mostram um aumento de valores para as borrachas butílicas e halobutílicas contendo borracha recuperada, possivelmente devido à presença de agente de cura residual na borracha recuperada ${ }^{161}$. O aumento de valores de $\mathrm{MH}$ foi mais acentuado para as borrachas butílicas e halobutílicas curadas com resina (RC 1, RC 4 e RC 7), em função do baixo índice de vulcanização, característico desse sistema de cura e da possibilidade de existir em aglomerados de partículas vulcanizadas não dispersas na matriz polimérica ${ }^{162}$.

Analisando as diferenças entre os torques, $\Delta \mathrm{M}(\mathrm{MH}-\mathrm{ML})$, como um indicativo da influência da borracha recuperada nos compostos de borracha butílica e halobutílicas, uma vez que, a diferença entre os torques máximo e mínimo está relacionado ao grau de cura. Observou-se que $\Delta \mathrm{M}$ diminui ligeiramente com a adição da borracha recuperada, para as formulações que contém borracha virgem mais borracha recuperada e os sistemas de cura utilizados foram enxofre e doador de enxofre $(R C 2, R C 3, R C 5, R C 6, R C$, e $\mathrm{RC} 9$ ), indicando a presença de enxofre residual na borracha recuperada.

O $\mathrm{T}_{\mathrm{s} 1}$ é um parâmetro importante fornecido pelo reômetro de disco oscilatório, pois indica o tempo de segurança de processo, isto é, o tempo limite para o início da formação de ligações cruzadas. Os resultados de todas as 
formulações preparadas com $70 \mathrm{phr}$ de borracha virgem mais $30 \mathrm{phr}$ de borracha recuperada, indicam um decréscimo desse valor, quando comparados aos compostos contendo $100 \mathrm{phr}$ de borracha virgem, SUGERINDO que as borrachas butílica e halobutílicas recuperadas ainda possuem algum tipo de aceleração residual. Esses resultados permitem que os artefatos produzidos com esses compostos sejam obtidos em tempos similares aos fabricados com misturas contendo $100 \mathrm{phr}$ de borracha virgem.

TABELA 20: Parâmetros reométricos dos compostos de borracha butílica e halobutílicas com $100 \mathrm{phr}$ de borracha virgem e com $70 \mathrm{phr}$ de borracha virgem +30 phr de borracha irradiada e cisalhada.

\begin{tabular}{|c|c|c|c|c|}
\hline Compostos & $\mathrm{MH}(\mathrm{dN} . \mathrm{m})$ & $\mathrm{ML}(\mathrm{dN} . \mathrm{m})$ & $\Delta \mathrm{M}(\mathrm{dN} . \mathrm{m})$ & Ts1 (Min) \\
\hline $\mathrm{RC} 1$ & 21,46 & 3,60 & 17,86 & 0,70 \\
\hline AM1 & 14,03 & 3,09 & 10,94 & 1,21 \\
\hline RC2 & 9,75 & 2,00 & 7,75 & 0,74 \\
\hline AM2 & 9,59 & 1,53 & 8,06 & 1,00 \\
\hline $\mathrm{RC} 3$ & 9,54 & 1,51 & 8,13 & 1,00 \\
\hline AM3 & 9,43 & 1,27 & 8,16 & 1,18 \\
\hline RC4 & 17,57 & 4,44 & 13,13 & 0,41 \\
\hline AM4 & 14,81 & 3,43 & 11,38 & 0,73 \\
\hline RC5 & 5,25 & 2,02 & 3,23 & 0,89 \\
\hline AM5 & 5,15 & 1,78 & 3,37 & 1,01 \\
\hline RC6 & 7,20 & 5,03 & 2,17 & 0,70 \\
\hline AM6 & 6,11 & 3,88 & 2,23 & 2,25 \\
\hline $\mathrm{RC} 7$ & 24,03 & 4,70 & 19,33 & 0,40 \\
\hline AM7 & 21,33 & 2,71 & 18,62 & 0,81 \\
\hline RC8 & 7,36 & 1,81 & 5,55 & 0,88 \\
\hline AM8 & 6,71 & 0,92 & 5,79 & 0,93 \\
\hline $\mathrm{RC} 9$ & 7,53 & 2,57 & 4,96 & 0,46 \\
\hline AM9 & 7,38 & 1,76 & 5,62 & 0,63 \\
\hline
\end{tabular}

"ML: Torque mínimo; $\mathrm{MH}$ : torque máximo; $\Delta \mathrm{M}$ : diferença entre os torques (MH - ML); e Ts1: tempo de segurança de processo." 
A TAB. 21 mostra os valores de $T_{90}$ dos compostos contendo borracha recuperada.

TABELA 21: Tempo ( $\left.T_{90}\right)$ e temperatura de vulcanização dos compostos de borrachas butílica e halobutílica contendo 70 phr de borracha virgem e 30 phr de borracha irradiada e cisalhada.

\begin{tabular}{l|c|c}
\hline \multicolumn{1}{c|}{ Amostras } & T & Temperatura de \\
\hline (Butílica vulc. com resina) & 37 & 190 \\
\hline RC 2 (Butílica vulc. com S) & 7 & 180 \\
\hline RC 3 (Butílica vulc. com doador de S) & 7 & 180 \\
\hline RC 4 (Bromobutílica vulc. com resina) & 24 & 190 \\
\hline RC 5 (Bromobutílica vulc. com S) & 2 & 180 \\
\hline RC 6 (Bromobutílica vulc. com doador de S) & 1,5 & 180 \\
\hline RC 7 (Clorobutílica vulc. com resina) & 19 & 190 \\
\hline RC 8 (Clorobutílica vulc. com S) & 4 & 180 \\
\hline RC 9 (Clorobutílica vulc. com doador de S) & 3 & 180 \\
\hline
\end{tabular}

\subsubsection{Tensão e alongamento na ruptura}

A resistência à tração é uma propriedade importante na determinação do melhor desempenho mecânico de formulações elastoméricas. Os resultados de tensão na ruptura realizados nas formulações desenvolvidas com borracha recuperada e nas formulações contendo $100 \%$ de borracha virgem, estão apresentados na FIG. 94. 


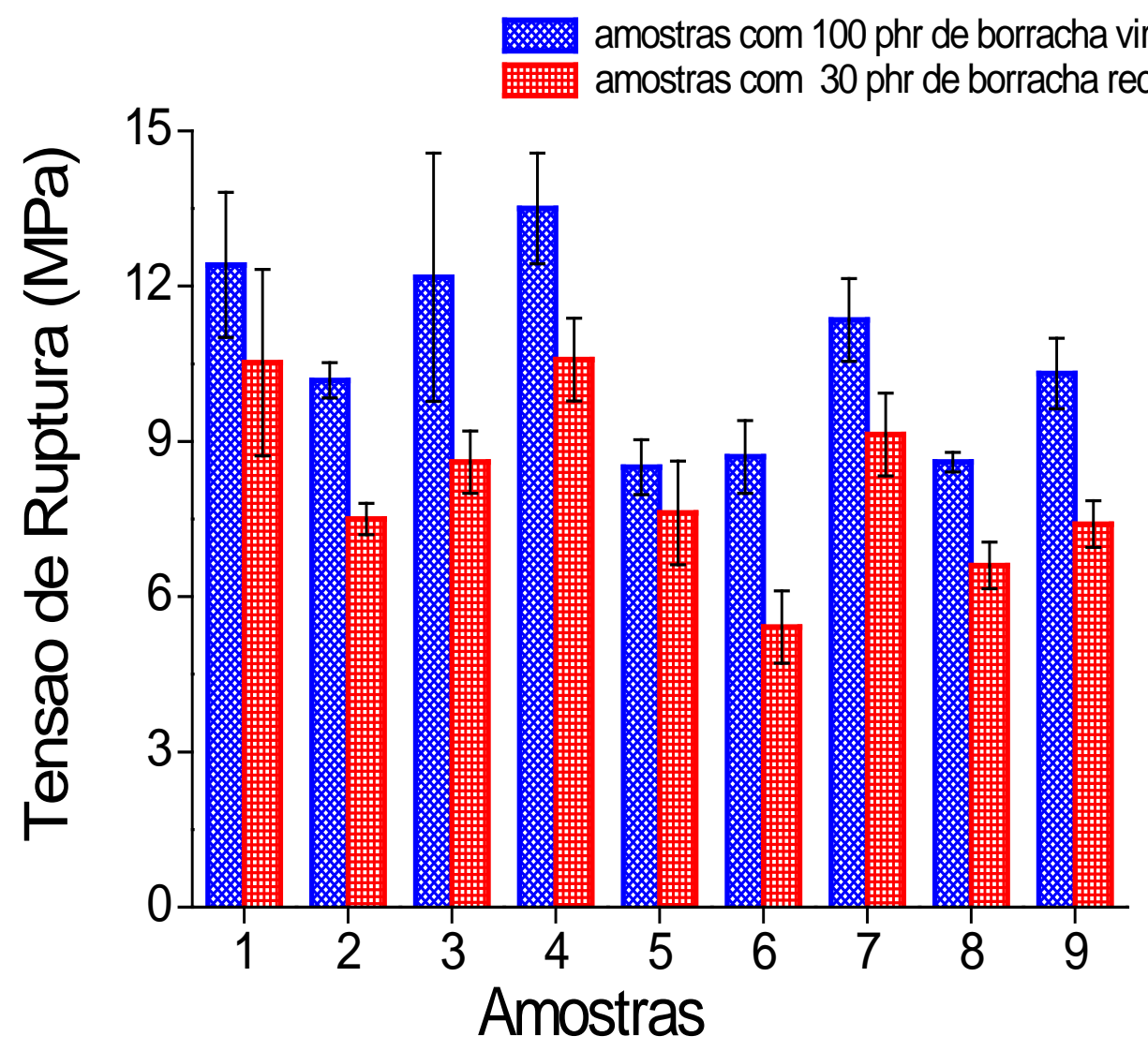

FIGURA 94: Resultado de tensão na ruptura dos compostos de borracha butílica e halobutílicas com 100 phr de borra virgem (azul) e com70 phr de borracha virgem $+30 \mathrm{phr}$ de borracha recuperada enxofre (vermelho).

Observou-se decréscimo de valores de tensão na ruptura para todas os compostos formulados com borracha recuperada, independente do tipo de borracha. A possível explicação para essa diminuição, é que a adição de borracha irradiada que também sofreu cisalhamento intenso apresentou-se muito degradada (massa molar muito baixa). Portanto, a adição de uma quantidade significativa de borracha de massa molar muito baixa propicia a formação de forças intermoleculares mais fracas que facilitam o rompimento das cadeias. Pode ocorrer também a formação de falhas proveniente da adição dos resíduos gelificados (ainda vulcanizados) que geram pontos de tensão concentrada, tornando a borracha mais frágil e, portanto suscetível a rompimentos ${ }^{163}$.

O alongamento na ruptura também está relacionado com a rigidez molecular. Os resultados das análises realizadas nas formulações contendo 30 
phr de borracha recuperada e nas formulações contendo $100 \%$ de borracha virgem, são mostradas na FIG. 95.

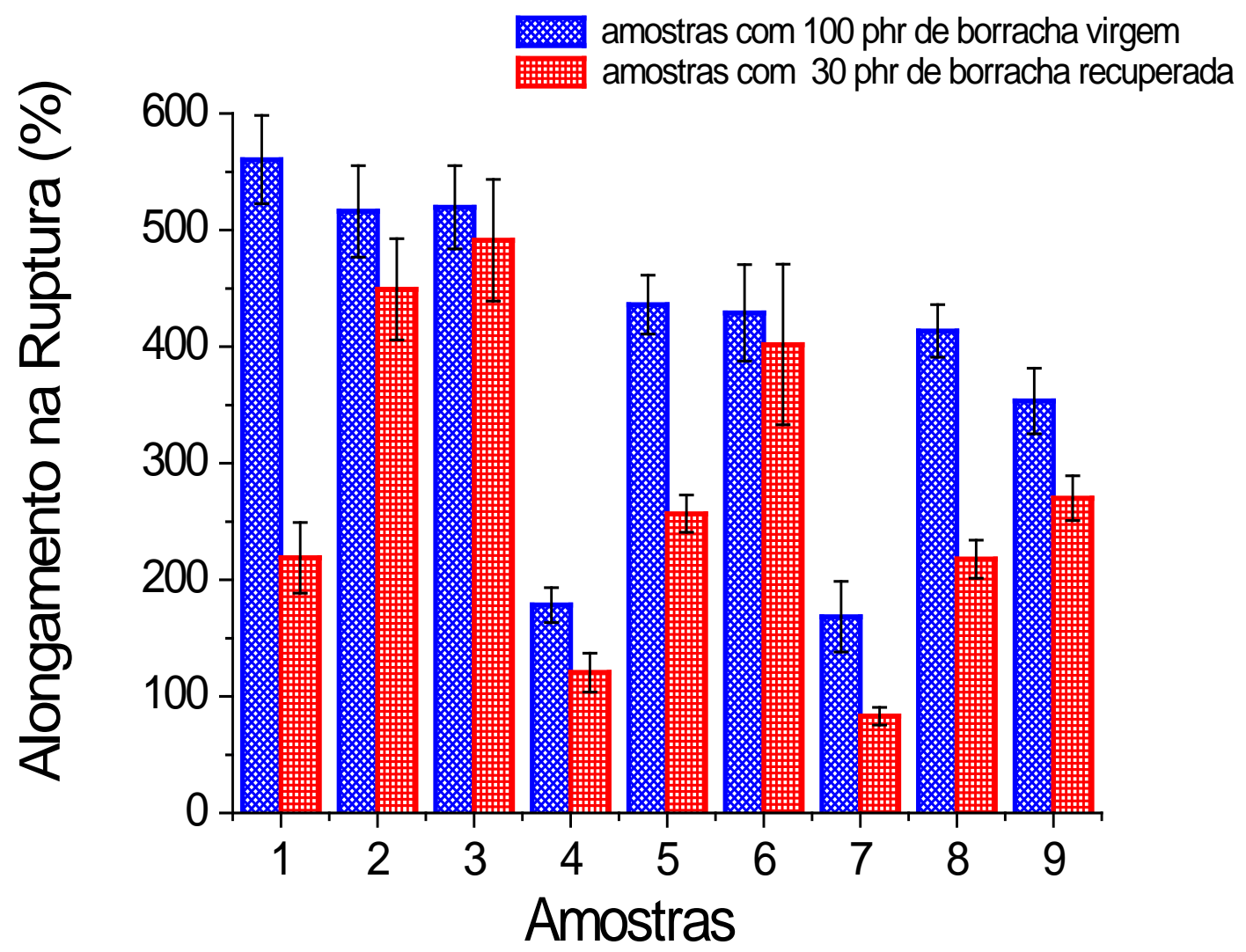

FIGURA 95: Resultado de alongamento na ruptura dos compostos de borracha butílica e halobutílicas com 100 phr de borra virgem (azul) e com 70 phr de borracha virgem $+30 \mathrm{phr}$ de borracha recuperada enxofre (vermelho).

O alongamento na ruptura das composições contendo borrachas butílicas e halobutílicas recuperadas, apresentou resultados compatíveis aos encontrados para tensão de ruptura. Observou-se uma redução no alongamento na ruptura para todas as amostras que contêm 30 phr de borracha recuperada. Provavelmente a adição de borracha recuperada, com baixa massa molar aumentou a rigidez molecular, pois compostos de borracha de baixa massa molar alongam menos. 
Esses resultados, podem também estar relacionados à presença de pequenas partículas de borracha não incorporadas no composto que contém borracha recuperada, sugerindo que a presença de partículas e aglomerados de borracha recuperada na matriz polimérica, pode contribuir para o decréscimo do alongamento uma vez que impede que as cadeias poliméricas deslizem umas sobre as outras.

\subsubsection{Dureza}

Os resultados dos testes de dureza dos compostos contendo borracha recuperada e compostos com 100\% de borracha virgem, estão mostrados na FIG. 96.

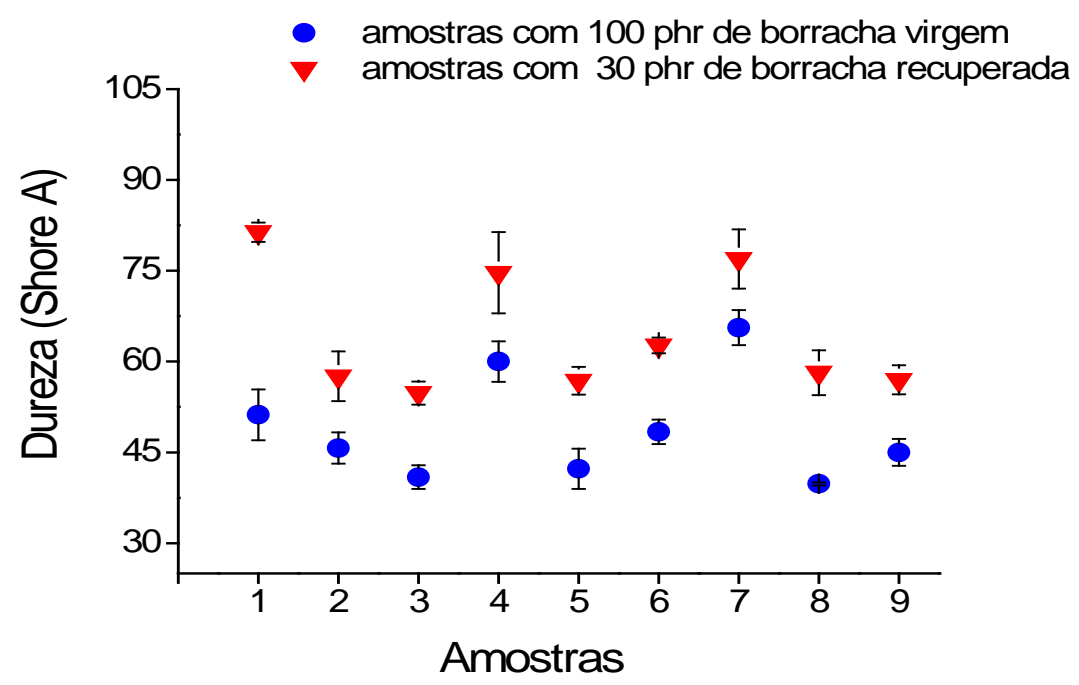

FIGURA 96: Resultado da dureza dos compostos de borracha butílica e halobutílicas com $100 \mathrm{phr}$ de borracha virgem (azul) e com $70 \mathrm{phr}$ de borracha virgem $+30 \mathrm{phr}$ de borracha recuperada enxofre (vermelho).

A dureza apresentou o mesmo comportamento do torque máximo, isto é aumentou com a incorporação da borracha recuperada. Esses resultados podem ser comparados, pois ambos estão associados à rigidez do material. $O$ maior acréscimo de valores de dureza foi observado para as amostras de borrachas butílica e halobutílicas, contendo borracha recuperada curada com resina ( $R C$ 1, RC 4 e $R C$ 7) devido à adição de borracha de baixa massa molar. 
Pois as moléculas de baixa massa molar possuem maior mobilidade e permitem um melhor empacotamento molecular causando aumento da dureza. Além disso, os resíduos de borracha recuperada por irradiação e cisalhamento, podem conter agentes de cura residual, que podem aumentar o grau de cura e consequentemente a dureza da borracha.

\subsubsection{Inchamento}

Os resultados de inchamento das amostras de borrachas butílicas e halobutílicas contendo $30 \mathrm{phr}$ de borracha recuperada e borrachas butílicas e halobutílica contendo 100\% de borracha virgem, são mostrados na FIG. 97.

Observou-se que todos os compostos de borracha butílica e halobutílicas contendo $30 \mathrm{phr}$ de borracha recuperada, independentemente do sistema de cura empregado apresentaram estabilização da variação de massa, após 24 horas de imersão no solvente a exemplo de todos os ensaios de inchamento das borrachas não recuperadas que também mostraram estabilidade após 24 horas.

As composições de borrachas butílicas, bromobutílicas e clorobutílicas contendo $30 \mathrm{phr}$ de borrachas recuperadas e curadas com doador de enxofre foram as que apresentaram maior índice de inchamento sugerindo menor densidade de reticulação. 


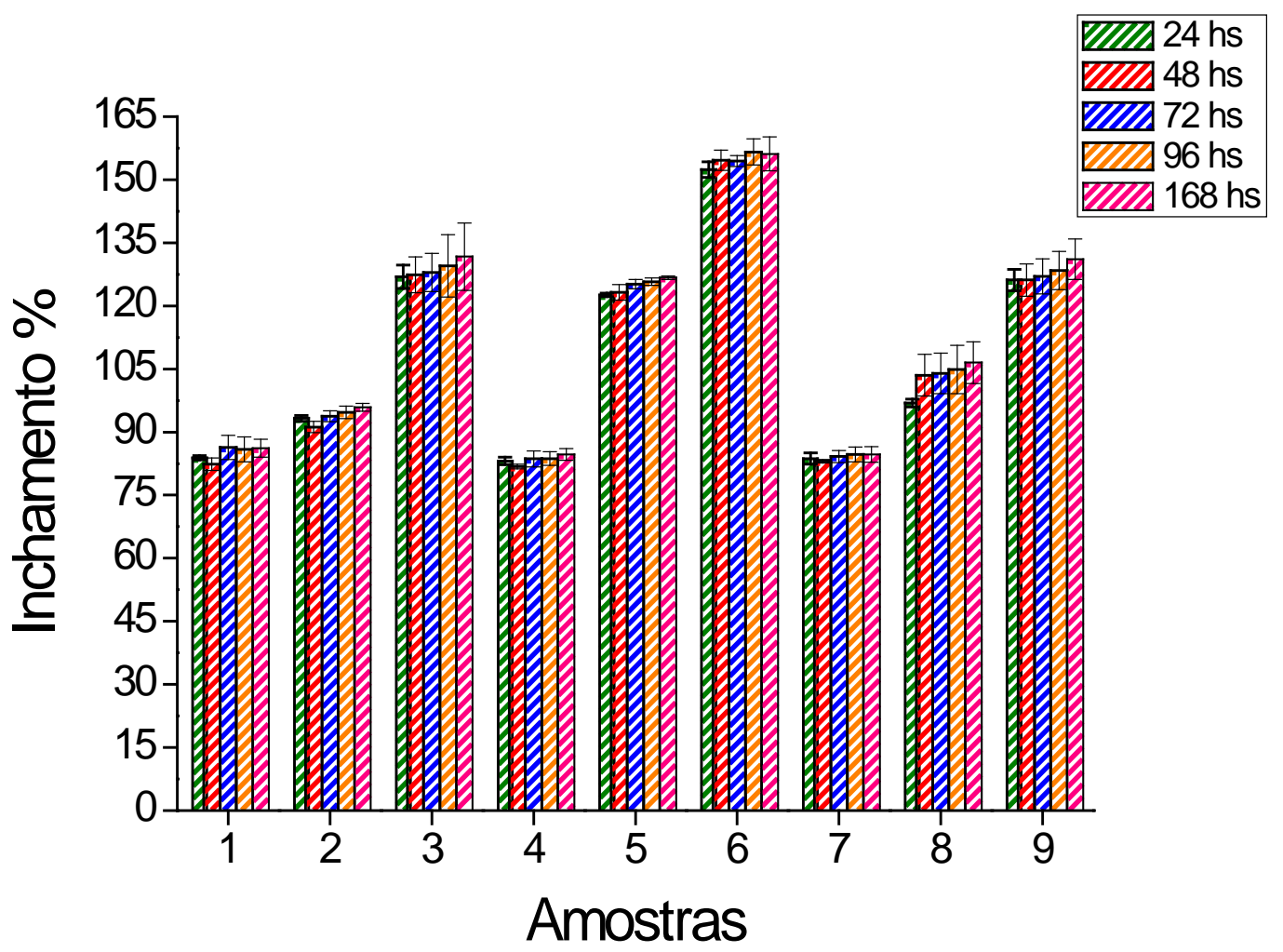

FIGURA 97: Resultado de inchamento dos compostos de borracha butílica e halobutílicas com 70 phr de borracha virgem +30 phr de borracha recuperada.

A TAB. 22 apresenta a variação de massa seca dos compostos de borrachas butílicas, bromobutílica e clorobutílicas contendo 30 phr de borracha recuperada por irradiação e cisalhamento. Observou-se que os compostos butílicos e halobutílicos contendo borracha recuperada e curadas com resina, foram os que apresentaram massa inicial maior que a massa seca, após o teste de inchamento, mostrando que o solvente enfrenta um a maior dificuldade para escapar, sugerindo uma menor porosidade.

A massa seca das amostras curadas com enxofre e doador de enxofre ( $R C$ 2, RC 3, RC 5, RC 6, RC 8, RC 9) apresentou valores da ordem de 6 a 8\% de perda de massa. Portanto os valores de inchamento da FIG. 97 dessas amostras é ainda maior que o valor apresentado antes do inchamento, evidenciando que o sistema de cura por resina favorece uma maior densidade de reticulação. 
A FIG. 98 mostra a imagem das amostras de borracha contendo $30 \mathrm{phr}$ recuperada e $70 \mathrm{phr}$ de borracha virgem, após o teste de inchamento. Verificou-se que, principalmente para as amostras curadas com resina o solvente se torna amarelado. Possivelmente a cor amarelada ocorre devido à extração de resina fenólica não reagida. Para as amostras curadas com enxofre e doador de enxofre o amarelamento é muito suave.

TABELA 22: Variação da massa seca dos compostos de borrachas butílicas, bromobutílica e clorobutílica contendo $30 \mathrm{phr}$ de borracha recuperada.

\begin{tabular}{l|c}
\hline Composição & Massa seca (\%) \\
\hline RC - 1 & 5,59 \\
\hline$R C-2$ & $-7,32$ \\
\hline$R C-3$ & $-6,71$ \\
\hline$R C-4$ & 6,34 \\
\hline$R C-5$ & $-7,58$ \\
\hline$R C-6$ & $-7,08$ \\
\hline$R C-7$ & 9,87 \\
\hline$R C-8$ & $-8,53$ \\
\hline$R C-9$ & $-0,24$ \\
\hline
\end{tabular}




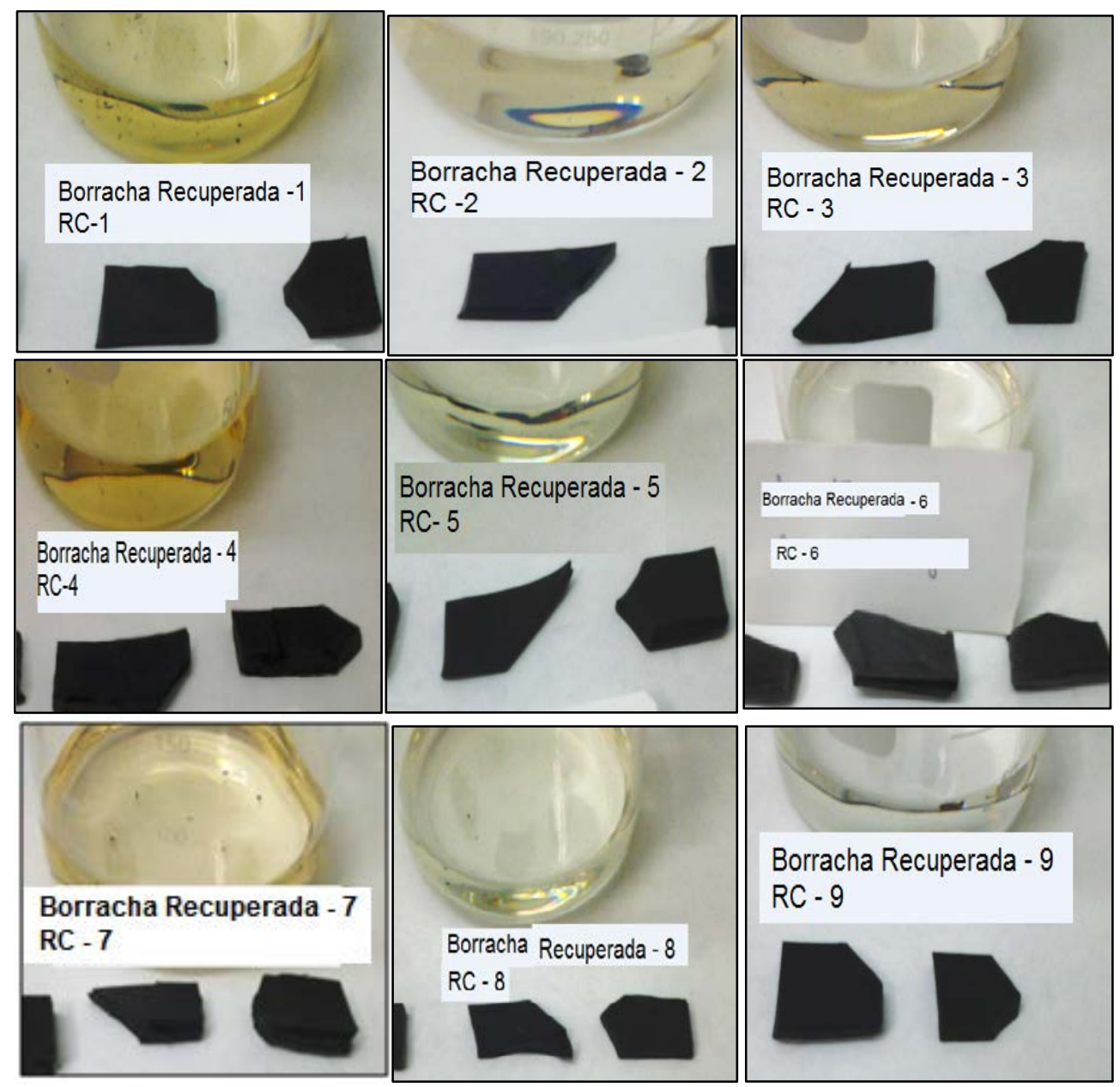

FIGURA 98: Imagem das borrachas butílicas, bromobutílica e clorobutílicas contendo 30 phr de borracha recuperada por irradiação e cisalhamento, após o teste de inchamento.

\subsubsection{Microscopia Eletrônica de Varredura (MEV)}

Na FIG. 99 são mostradas as micrografias da superfície de ruptura, aumentadas 250 vezes, dos compostos de borrachas butílicas formulados com 70 phr de borracha virgem e 30 phr de borracha recuperada. 


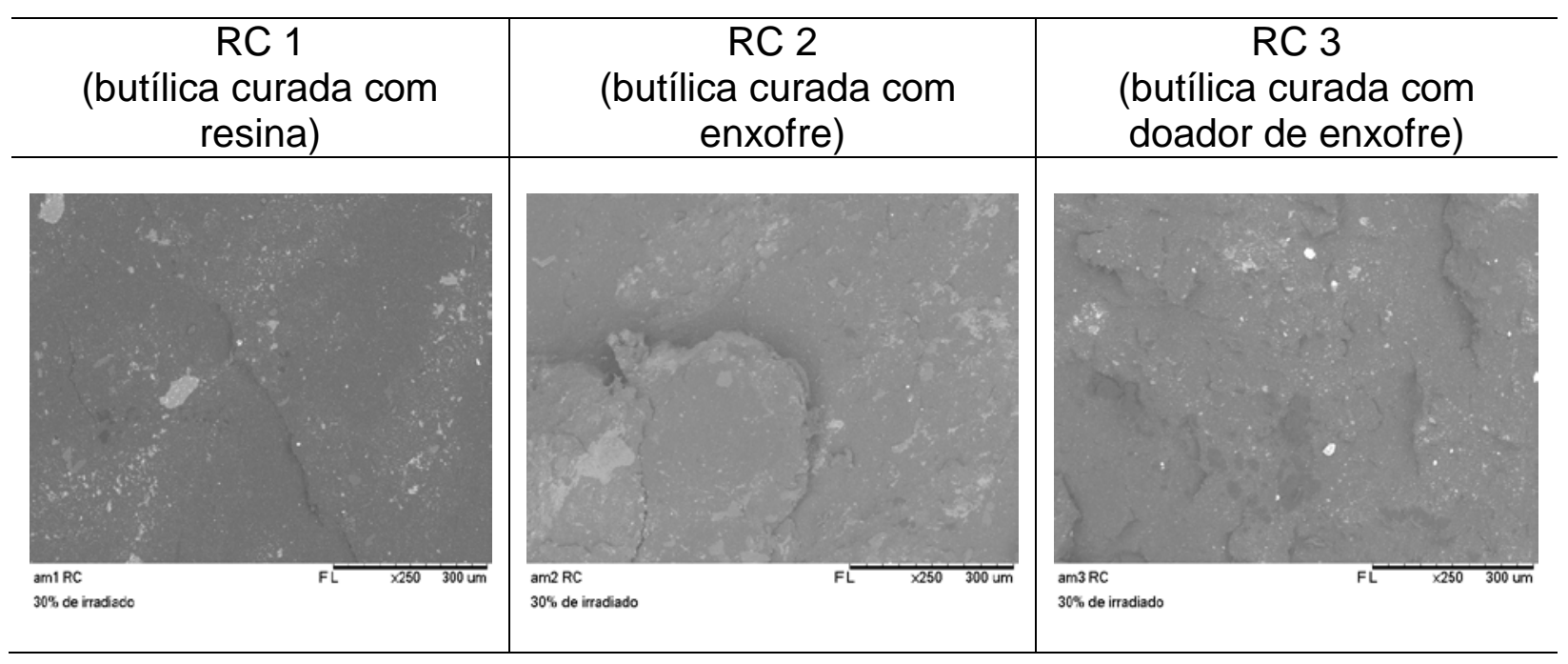

FIGURA 99: Micrografias da superfície de ruptura dos compostos de borracha butílica contendo 30 phr de borracha irradiada e cisalhada curados com resina ( $R C-1)$, enxofre ( $R C-2)$ e doador de enxofre $(R C-3)$.

Os compostos desenvolvidos a partir de 70 phr de borracha butílica virgem e 30 phr de borracha butílica recuperadas, curadas com resina (RC-1), enxofre (RC-2) e doador de enxofre (RC-3), apresentaram heterogeneidade na dispersão e distribuição de partículas de borracha recuperada, ou seja, observamse algumas partículas do resíduo de borracha recuperada e certa rugosidade na superfície de fratura das amostras, indicando questões de homogeneidade.

A FIG. 100, mostra as micrografias realizadas na superfície de ruptura dos compostos de borrachas bromobutílicas, curados com resina, enxofre e doador de enxofre, formulados com 70 phr de borracha virgem e 30 phr de borracha recuperada. 


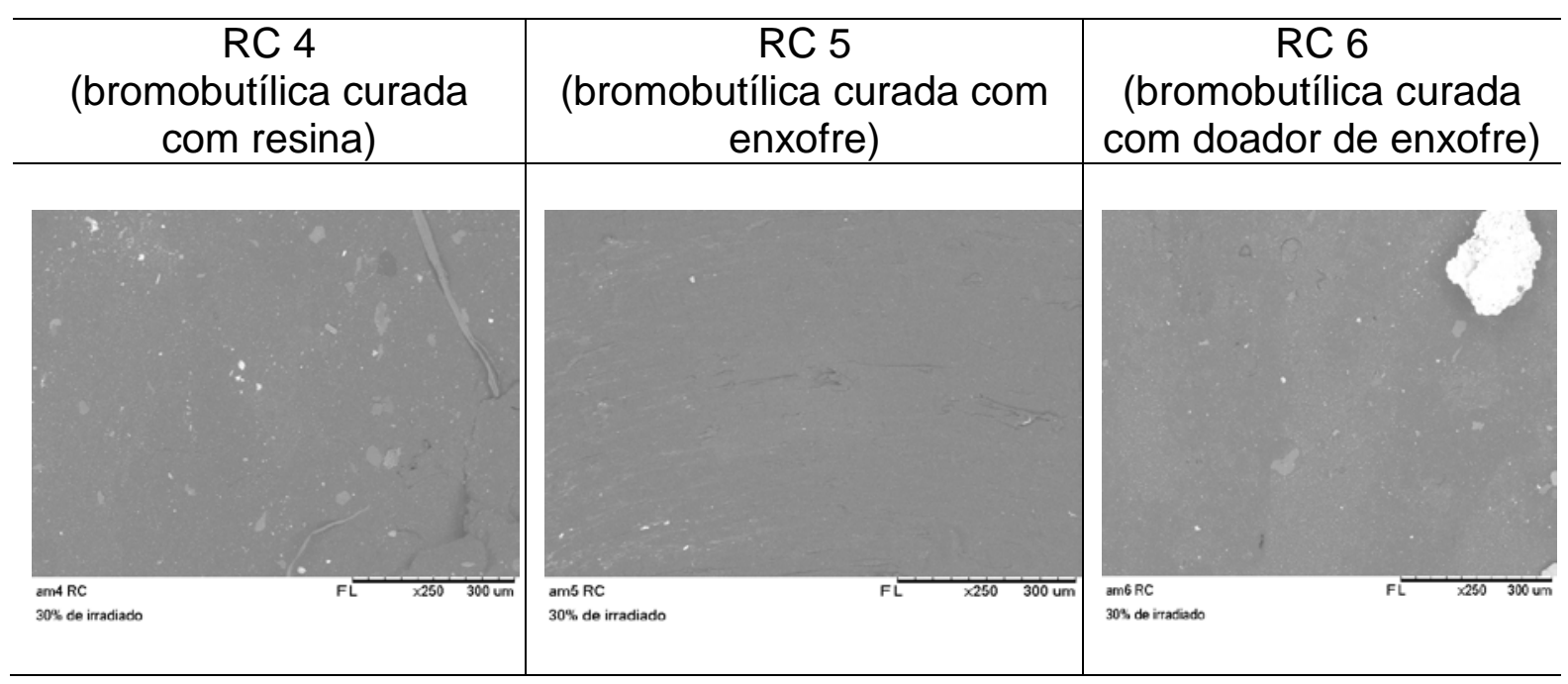

FIGURA 100: Micrografias da superfície de ruptura dos compostos de borracha bromobutílica contendo 30 phr de borracha irradiada e cisalhada curados com resina (RC-4), enxofre (RC-5) e doador de enxofre (RC6).

Observa-se que as micrografias destes compostos apresentam uma maior homogeneidade e melhor distribuição do recuperado na matriz polimérica, quando comparadas com as micrografias das borrachas butílicas contendo borracha recuperada, porém ainda é possível visualizar aglomerados de partículas não dispersas ou pedaços de borracha recuperada na superfície de ruptura destes compostos.

Na FIG. 101 são mostradas as micrografias realizadas na superfície de ruptura dos compostos de borrachas clorobutílicas com 70 phr de borracha virgem e 30 phr de borracha recuperada.

As micrografias das composições de borracha clorobutílica contendo $30 \mathrm{phr}$ de borracha irradiada e cisalhada também mostraram falta de homogeneidade de distribuição de partículas. 


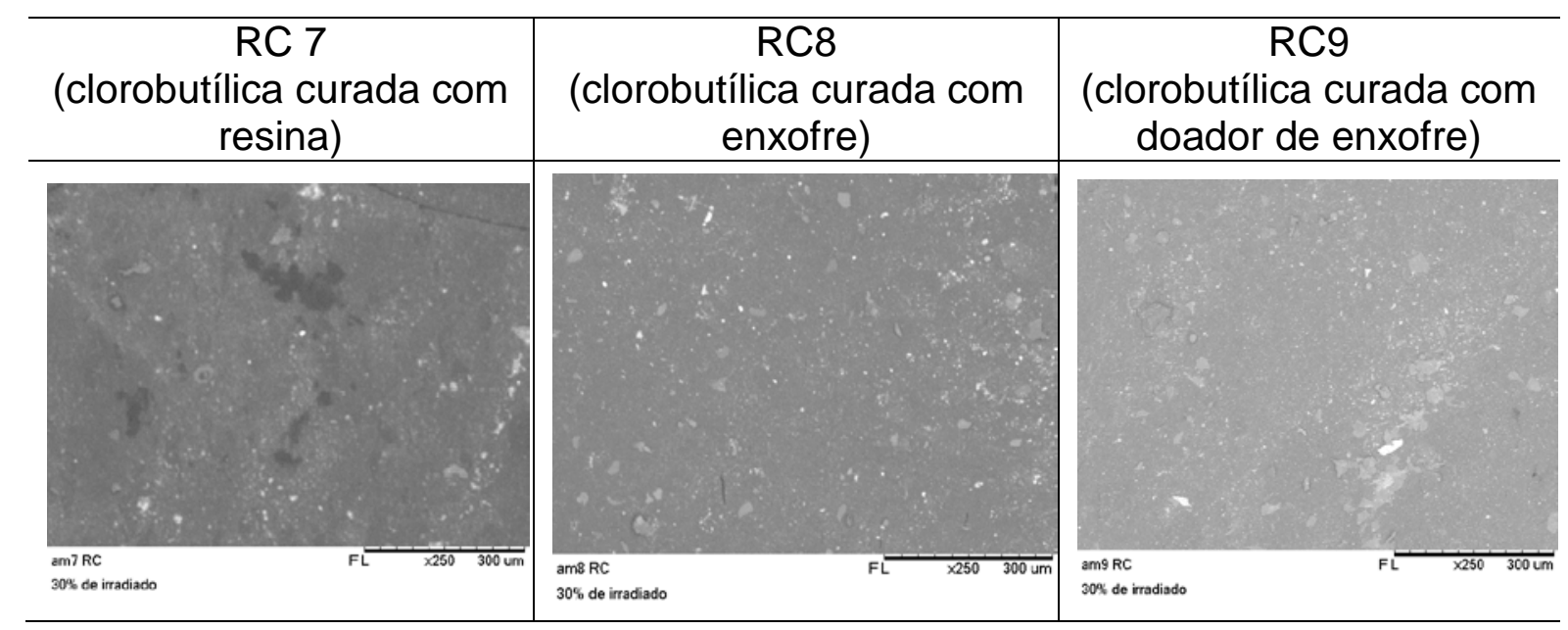

FIGURA 101: Micrografias da superfície de fratura dos compostos de borracha clorobutílica contendo phr de borracha irradiada e cisalhada curados com resina ( $R C-7)$, enxofre ( $R C-8)$ e doador de enxofre (RC-9).

As micrografias dos compostos de borrachas butílica e halobutílica confeccionadas com $70 \mathrm{phr}$ de borracha virgem e $30 \mathrm{phr}$ de borracha recuperada por irradiação e cisalhamento corroboraram com o decréscimo das propriedades de tensão e alongamento na ruptura, e o acréscimo de valores de dureza.

\subsubsection{Viscosidade Mooney dos compostos recuperados/reciclados}

Na FIG. 102, são mostrados os resultados de viscosidade Mooney dos compostos de borrachas butílicas, bromobutílicas e clorobutílicas, contendo 70 phr de borracha virgem e $30 \mathrm{phr}$ de borracha recuperada, curadas com resina, enxofre e doador de enxofre. 


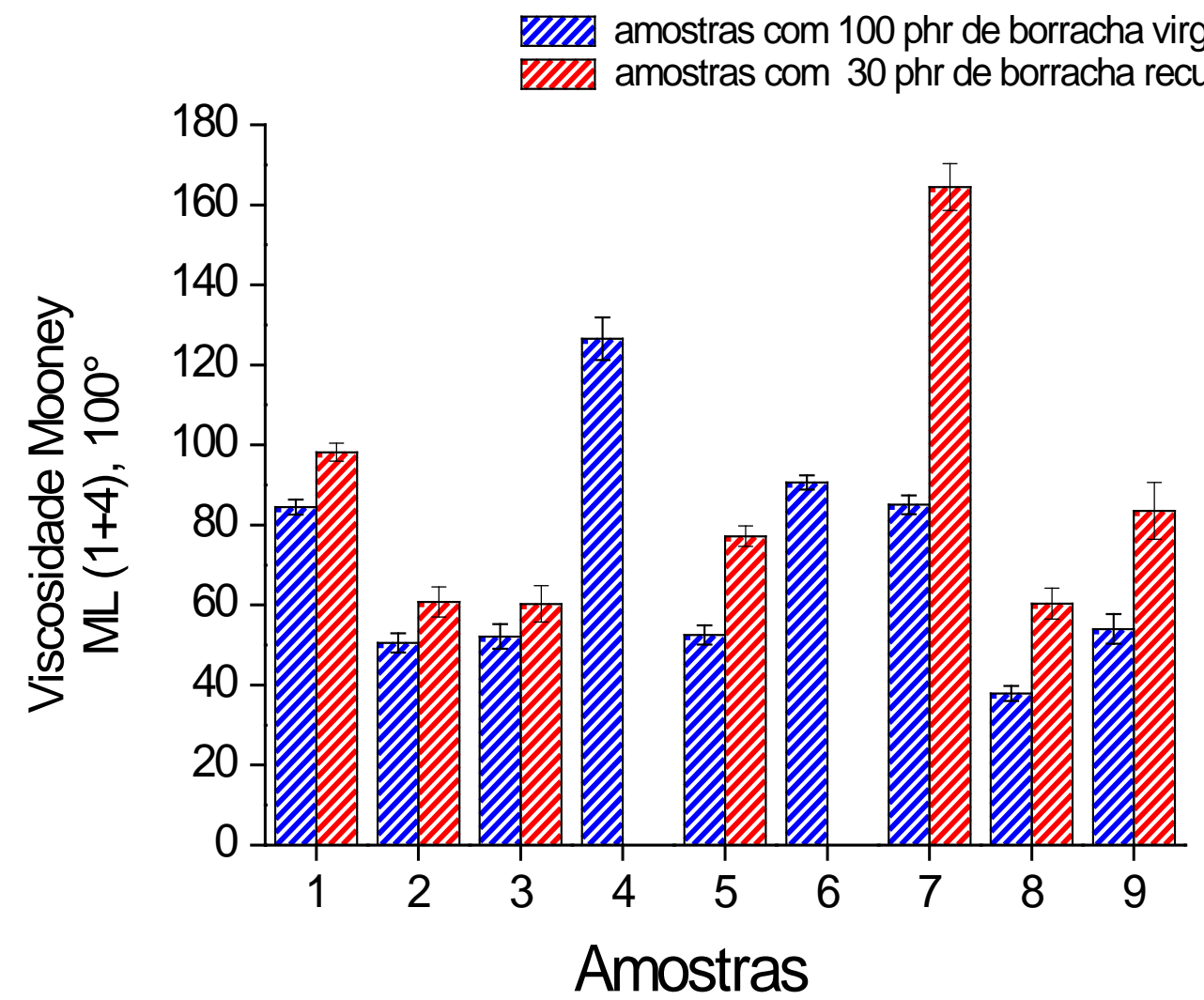

FIGURA 102: Viscosidade Mooney $\mathrm{ML}(1+4), 100^{\circ} \mathrm{C}$ dos compostos de borracha butílica e halobutílicas formulados com $100 \mathrm{phr}$ de borracha virgem e compostos de borracha butílica e halobutílicas formulados com 30phr de borracha recuperada por irradiação e cisalhamento.

A viscosidade Mooney é afetada da mesma maneira que o torque mínimo, pela adição de borracha recuperada. Observa-se que a viscosidade Mooney dos compostos formulados com borracha recuperada por irradiação e cisalhamento é superior à dos compostos formulados com 100 phr de borracha virgem, indicando que o processamento destas amostras é um pouco mais difícil. Não foi possível a medição da viscosidade para os compostos RC-4 (borracha bromobutílica curada com resina) e RC 6 (bromobutílica curada com doador de enxofre), pois o equipamento travou em virtude do torque muito elevado para a medição, possivelmente em função do excesso de reticulação. 
O aumento dos valores da viscosidade Mooney está relacionado com o da massa molar da borracha. A adição de borracha recuperada por irradiação que sofreu intensa cisão de cadeia em um composto com borracha virgem, significa misturar uma borracha de massa molar alta com uma borracha de baixa massa molar , pois esta pode apresentar ramificações longas que ao serem incorporadas podem apresentar tendência a impedir o deslizamento de nós e o alinhamento da cadeia polimérica $^{164}$ induzindo aumento da viscosidade Mooney. Da mesma forma, a estrutura ramificada do recuperado pode ocasionar o decréscimo das propriedades de tensão e alongamento na ruptura e o aumento da dureza. 


\section{CONCLUSÕES}

As borrachas butílicas, bromobutílicas e clorobutílicas, reagem de maneira distinta quando expostas a radiação. Os resultados da irradiação das borrachas puras (matéria-prima) mostraram que o principal efeito da radiação ionizante na borracha butílica é a cisão de cadeia. Para as borrachas bromobutilicas e clorobutílicas, a tendência é de equivalência entre cisão e reticulação.

Para as borrachas bromobutilicas e clorobutílicas, a tendência é de equivalência entre cisão e reticulação. Esses resultados são comportados pelas intensas ligações de hidrogênio em suas moléculas, que influenciam os resultados da Viscosidade Mooney.

O aspecto visual das borrachas butílica, bromobutílica e clorobutílica depois de irradiadas, confirmou que a borracha butílica sofreu intensa degradação com o aumento da dose, enquanto que as borrachas halogenadas com 0 aumento da dose apresentaram aspecto rígido e cor amarela mais intensa.

Os ensaios de DMA evidenciaram também que a borracha butílica curada com enxofre, para doses baixas de até 50 kGy há predomínio da cisão, e em doses mais elevadas (acima de 50 kGy), ligeira predominância da reticulação sobre a cisão.

Os ensaios mecânicos de tração e alongamento na ruptura, de modo geral mostraram cisão de cadeia para doses até 25 kGy e para doses superiores a 50 kGy degradação intensa, principalmente para a borracha butílica, as borrachas halogenadas são um pouco mais resistentes à radiação.

Os testes de inchamento mostraram que, as borrachas butílicas, bromobutílica e clorobutílicas apresentam tendência a cisão de cadeia. Entretanto a borracha butílica curada com resina apresentou estabilidade até a dose de 
50 kGy. Para dose maior ou igual a 100 kGy apresentou intensa degradação. Já a borracha butílica curada com enxofre em doses baixas, mostrou tendência à reticulação.

Os sistemas de cura com enxofre e doador de enxofre são mais resistentes à radiação ou protegem a borracha da radiação, quando comparados com o sistema de cura por resina fenólica, principalmente para a borracha bromobutílica.

As micrografias das amostras de borracha butílica, bromobutílica e clorobutílica, após a irradiação mostraram que em doses baixas uma superfície de ruptura suave, indicando cisão de cadeia. Para doses mais elevadas acima de 100 kGy, a superfície de ruptura apresenta trincas e falhas, atribuídas a regiões de extrema reticulação e oxidadas.

As análises de EDS, dos compostos de borracha butílica e halobutílicas, curadas com enxofre e doador e enxofre, mostraram que a irradiação pode interagir com o enxofre dos sistemas de cura destas borrachas.

Independentemente do sistema de cura, o cisalhamento mecânico da borracha butílica, bromobutílica e clorobutílica irradiadas, auxiliou na redução dos valores de torque máximo e torque mínimo.

Os compostos de borrachas butílicas, bromobutílica e clorobutílica que passaram pelo processo de irradiação seguido de cisalhamento em cilindro, mostraram destruição intensa das propriedades mecânicas.

Todos os compostos irradiados e cisalhados mostraram valores de dureza estáveis, porém muito baixo, indicando intensa degradação.

Os testes de inchamento mostraram que as amostras submetidas à irradiação e cisalhamento perdem muita massa. A borracha butílica irradiada e cisalhada, curada com resina, foi a que apresentou maior inchamento e completa dissolução da amostra. Evidenciando amplo predomínio da cisão. 
As micrografias das borrachas butílicas e halobutílicas irradiadas e cisalhadas, apresentam intensa rugosidade na superfície de ruptura, em todas as doses. Para doses acima de 100 kGy essa rugosidade é atenuada em função da cisão de cadeia.

As amostras de borrachas butílicas, bromobutílica e clorobutílicas, somente irradiadas não apresentaram resultados satisfatórios de degradação controlada, ou seja, alguns compostos ainda apresentavam evidência de reticulação, mesmo em doses elevadas (acima de 100 kGy).

As micrografias dos compostos contendo borrachas recuperadas, com 30 partes de borracha recuperada por irradiação e cisalhamento com 70 partes de borracha virgem, mostraram certa heterogeneidade na superfície da mistura, principalmente para a borracha butílica Entretanto esta rugosidade não afeta o processamento dos compostos e pouco interfere no produto final.

A avaliação das propriedades físico-químicas, dos compostos contendo borracha recuperada, mostrou que a influência da adição de borracha recuperada por irradiação e cisalhamento, propicia ligeiro decréscimo nos valores de tensão e alongamento na ruptura. Entretanto os resultados também indicam a compatibilidade dessa incorporação.

Os resultados de inchamento com solvente dos compostos contendo borracha recuperada também mostrou estabilidade de valores após 24 horas de imersão no solvente, indicando que a incorporação de resíduos de borracha recuperada não afeta a estabilidade de formação de ligações cruzadas.

O processamento com raios gama seguido de cisalhamento das borrachas butílicas, bromobutílicas e clorobutílicas, demonstra grande viabilidade técnica para a aplicação em processos industriais de recuperação deste tipo de borracha. Considerando as dificuldades em se reciclar borrachas vulcanizadas, principalmente quanto ao seu reprocessamento, destacam a importância e eficiência na incorporação de resíduos destes materiais em seu processo original sem a adição de nenhum aditivo. 
De um modo geral foi possível concluir, que apesar de ser necessário efetuar alguns ajustes nas formulações, contendo recuperado de borrachas butílicas e halobutílicas, a estratégia de irradiar e posteriormente cisalhar mostrou-se de grande potencial no cenário da reciclagem. 


\section{TRABALHOS FUTUROS}

Como sugestões pra trabalhos futuros, pode-se cogitar a mistura de partes de borracha reciclada, afim de determinar o limite máximo de incorporação de recuperado de borracha. Outra proposta para continuação deste trabalho é a execução do controle do cisalhamento da borracha irradiada. Uma terceira proposta para dar continuidade aos trabalhos seria confeccionar produtos com os compostos fabricados com borracha recuperada pelo processo de irradiação seguido de cisalhamento e avaliar a qualidade destes produtos. Outra possibilidade para futuros trabalhos é o testar o procedimento com diferentes tipos de borracha que deverá produzir resultados diversos dos aqui apresentados. 


\section{REFERÊNCIAS BIBLIOGRÁFICAS}

1. ADHIKARI; B.; DE, D.; MAITI, S., Reclamation and Recycling of Waste Rubber. Progress in Polymer Science, v. 25, n. 7, p. 909-948, 2000.

2. GAINES, L. L.; WOLSKY, A. M., Discarded Tires: Energy Conservation Through Alternative Uses by Energy and Environmental Systems Division, 1979, Disponível em: TDF-017- Discarded tires, Energy Conservation Through Alternatives Uses.pdf, Acesso em 20 jan. 2013.

3. FUKUMORI, K.; MATSUSHITA, M.; OKAMOTO, H.; SATO, N.; SUZUKI, Y.;TAKEUCHI, K., Recycling technology of tire rubber; JSAE Review, v. 23, p. 259-264, 2002.

4. ASSOCIAÇÃO BRASILEIRA DE NORMAS TÉCNICAS. NBR 10.004: Resíduos Sólidos - Classificação. Rio de Janeiro: 1987.

5. ASSOCIAÇÃO NACIONAL DA INDÚSTRIA DE PNEUMÁTICOS (ANIP). Disponível em: http://www.anip.com.br/?cont=dados. Acesso em 21 fev.2013

6. OS PRINCIPAIS DADOS DA RECICLANIP. Disponível em: http://www.reciclanip.com.br/v3/sala-imprensa/press-kit/os-principais-dadosda-reciclanip/36/20120619/. Acesso em 02 fev. 2013

7. LAGARINHOS, C. A. F.; TENÓRIO, J. A. S., Reciclagem de pneus: discussão do impacto da política brasileira. Engevista, v. 11, n. 1, p. 32-49, julho 2009.

8. PAPAUTSKY, D., Borracha Recuperação e Regeneração. Borracha Atual, v. 45, p.42-50, 1999.

9. CRESPO J. S.; ZANCHET, A.; DAL'ACQUA, N.; WEBER, T.; BRANDALISE, R. N.; NUNES, R. C. R., Propriedades Reométricas e Mecânicas e Morfologia de Compósitos Desenvolvidos com Resíduos Elastoméricos Vulcanizados, Polímeros Ciência e Tecnologia, v. 17, p. 23-27, 2007.

10. CARMINE, L.; QUADRINI, F. New Technological Solutions for Recycling Spent Tire Rubber, International Journal of Manufacturing, Materials, and Mechanical Engineering, v. 2 , p. 1-10, 2012. 
11. SREEJA, T. D. Cure Characteristics and Mechanical Properties of Short Nylon Fiber Reinforced Natural Rubber-Reclaimed Rubber Blends. Polymer Plastic Technology and Engineering, v. 42, p. 239-252, 2003.

12. GOODYEAR. As Origens da Goodyear. Disponível em: http://www.goodyear.com.br/empresa/goodyear-mundo/goodyearmundo.html. Acesso em 22 fev.2013

13. SUTANTO, P.; PICCHIONI, F.; JANSSEN, L.P.B.M. Modeling a continuous devulcanization in an extruder, Chemical Engineering Science, v. 61, p. 7077-7086, 2006.

14. Nicholas, P. P.; "Devulcanized rubber composition and process for preparing same"; US Patent 4161464, 17 Jul, 1979.

15. WESTINGHOUSE SAVANNAH RIVER COMPANY, LLC. Carl B. Fliermans; George G. Wicks. Combination Biological and Microwave Treatments of Used Rubber Products. US Patent 6407144 B1, 18 jun. 2002.

16. RECYCLATECH GROUP LIMITED. Inventors Nicholas Christofi, David Edward, John Geoffrey. Rubber Treatment Method. US Patent 2006/0293398 A1, 28 dec.2006.

17. THE UNIVERSITY OF AKRON. Jianhua Chen, Avraam Isayev. Continuous Ultrasonic Devulcanization of Vulcanized Elastomers, US Patent 5284625, 8 feb. 1994.

18. MARTINES, M.A.U.; DAVOLOS, M.R.; JAFELICCI JÚNIOR, M. O efeito do ultra-som em reações químicas. Química Nova, v.23, n.2, p.251-256, 2000.

19. SCURACCHIO, C. H.; BRETAS, R. E. S.; WAKI, D. A. Desvulcanização de Borracha de Pneu através de Microondas. Polímeros, São Carlos, v. 16, n. 4, p. 46-52, 2006.

20. RAKHMANKULOV, D.L.; SHAVSHUKOVA, S.YU; LATYPOVA, F.N.; ZORIN, V.V. Laboratory and Industrial Applications of Microwave Techniques. Russian Journal of Applied Chemistry, v.75, n.9, p.13771383, 2002.

21. WIEBECK H.; ESPER F.; FEIJÓ A. C. Tecnologia da Borracha. Cooperação Universidade Empresa CECAE/USP, 2002.

22. OHM, R.F. Introduction to the Structure and Properties of Rubber, In: The Vanderbilt Rubber Handbook, 13 ed. R.T. Vanderbilt Company, Inc. p. 2, 1990. 
23. STERN, H. J., History, In: Rubber Technology and Manufacture, cap.1, C. M. Blow (ed), London: Newnes-Butterworths, 1975.

24. SHREVE, R. N.; BRINK JR., J. A. Indústrias da borracha, In: Indústria de Processos Químicos, cap.36, Rio de Janeiro: Editora Guanabara, 1977.

25. MONTENEGRO, R. S. P.; PAN, S. S. K. Panorama do Setor de Borrachas. Disponível em:

www.bndespar.com.br/conhecimento/bnset/borrach2.pdf. Acesso em: 5 Nov. 2012.

26. FANG,Y.; ZHAN, M.; WANG, Y. The Status of Recycling Waste Rubber, Materials \& Designs. v. 22, n. 2, p. 123-128, 2001.

27. HILLS, D. A., Heat Transfer and vulcanization of rubber. London: Elsevier Publishing Company Limited, v.. 4, n. 8, p. 72-75, 1971

28. MANO, E. B.; MENDES, L. C., Introdução a Polímeros, São Paulo:2a ed. Editora Edgard Blucher, 1999.

29. Associação Brasileira da Indústria de Artefatos de Borracha - ABIARB. Disponível: http://www.goodyear.com/corporate/history/history story.html. Acesso em: 24 fev 2013.

30. Anuário Brasileiro da Borracha, Artefatos Leves, História da borracha, Ano II, n. 12, Editora Borracha Atual, p. 10-11.Ed. 1997 (Set/Out 97).

31. Borracha Sintética, A história de uma indústria, Holanda: International Institute of Synthetic Rubber Producers Inc., 1973.

32. AHEMED, R.; KLUDENDERT, A.V.; LARDINOIS, I., Ruber Waste Options for Small-scale Resource Recovery- Urban Solid Waste, Series 3 ,Chap.1, p.11, 1996. Disponível em:

$<$ http://www.waste.nl/content/download/292/23309

/file/uw3\%20rubber\%20eng\%20ebook.pdf>. Acesso em: 4 Nov. 2012.

33. GOODYEAR, C., Improvement in Índia-Rubber Fabrics, US Patent 3633, 15 jun. 1844.

34. COSTA, H. M.; VISCONTE L. L. Y.; NUNES R. C. R.; FURTADO C. R. G. Aspectos Históricos da Vulcanização, Polímeros Ciência e Tecnologia, v.13, n.2, p.125-129, 2003.

35. PETROFLEX. A Borracha - Um pouco da história da borracha. Disponível em: <http://www.petroflex.com.br/perfil_borracha.htm>. Acesso em: 21 Jan. 2013. 
36. KRESJA, M. R.; KOENIG, J. L. A Review of Sulfur Crosslinking Fundamentals for Accelerated and Unaccelerated Vulcanization, Rubber Chemistry and Technology, v. 66, p. 376 - 410, 1993.

37. ANDRÉ, M.; WRIGGERS, P. Thermo-Mechanical Behavior of Rubber Materials During Vulcanization. International Journal of Solids and Structures, v. 42, p. 4758-4778, 2000.

38. CORAN, A. Y. in: Handbook of elastomers - new developments and technology, Stephens H. L., (ed.), Dekker Inc, New York, 1988.

39. LAYER, R. W. Recuring Vulcanizates: A Novel Way to Study the Mechanism of Vulcanization. Rubber Chemistry and Technology, The B. F. Goodrich Company, v. 65, p.211-222, 1992.

40. BATMAN, L.; Moore, C. G.; Porter, B.; Saville, B. Vulcanization, In: The Chemistry and Physics of Rubber-Like Substances, cap.15, London: Maclaren and Sons Ltd., 1963.

41. COLEMAN, M. M.; SHELTON, J. R.; KOENING, J. L. Sulfur Vulcanization of Hydrocarbon Diene Elastomers. Industry Engineering Chemistry Research, v. 13, p.154, 1974.

42. CARVALHO, P. H. V. Caracterização do Envelhecimento Termomecânico de Compostos de Borracha Utilizados em Pneus Visando a Aplicação em Simulações pelo Método de Elementos Finitos. São Paulo, 2006. Dissertação (Mestrado), EPUSP, Brasil.

43. CAPELLE, G. Calendaring technology. In: Bhowmick A. N.; Hall, M. M.;Benarey, H. A. (Ed). Rubber Products Manufacturing. Nova York, Marcel Dekker, cap.4, 1994.

44. JÚNIOR, D. H. L. Theory \& Practice of Vulcanization. In: Seals Easterrn Inc., Nova Jersey: Communication Chanel Inc, 1984.

45. BIN CHUNG, H. R.; MILLER, T. Cure System and Carbon Black Effects on NR Compound Performance in Truck Tires. In: Rubber Division Meeting, Cleveland, Ohio, Out. 16-19, 2001.

46. PARKS, C. R.; PARKER D. K.; CHAPMAN, D. A.; COX, W. L. Pendent Accelerator Groups in Rubber Vulcanizates. In: Rubber Chemistry and Technology, Vol. 43, No. 3, p. 572-587, 1970.

47. PARKS, C. R.; PARKER D. K.; CHAPMAN, D. A.; Cox, W. L. Pendent Accelerator Groups in Rubber Vulcanizates. In: Rubber Chemistry and Technology, Vol. 45, No. 2, pp. 467-480, 1972. 
48. MORRISON, N.J.; PORTER, M. A. Thermal Analysis Study Of The Interactions Of Curatives in the Accelerated Sulphur Vulcanization System., Rubber Chem. Technology, v. 57, p.63- 85, 1984

49. TOTH, W. J.; CHANG, J. P.; ZANICHEELLI, C. Finite Element Evaluation of Cure in a Tire, Tire Science \& Technology, TSTCA, v. 19, n.4, 1991.

50. CORAN, A. Y. - Science and Technology of Rubber - cap.7, F. R. Eirich (ed.), Academic Press Inc., London, 1978.

51. RODGERS, B. Rubber Compounding: Chemistry and Applications. New York, N.Y.: Marcel Dekker, 2004.

52. TAYLOR, G. R.; DARIN, S. R., The Tensile Strength of Elastomer. Journal of Polymer Science, v. 17, n. 86, p.511-525, 1955.

53. BUECHE, F.; DUDEK, T. J. Tensile Strenght of Amorfous Gum Rubbers. Rubber Chemistry and Technology, v. 36, n. 1, p.1-10, 1963.

54. HAGEM, R.; SALMÉM, I.; STEMBERG, B. Effects of the Type of Crosslinking on Viscoelastic Properties of natural Rubber. Journal of Polymer Science, Part B Polymer Physics, v. 34, n. 12, p. 1997-2006, 1998.

55. CHAKRABORTY, S. K.; BHOWMICK, A. K.; DE, S.K.J. Mixed Cross-Link Systems in Elastomers. J. Micromoles Sci Rev. Macromol Chem Phys., v. 82, C21, p. 313 - 332, 1981.

56. DATTA,R.N, Rubber Curing Systems (B V Flexsys). Editorial: Shrewsbury: Smithers Rapra Pub,v. 12, 2002

57. ROCHA, E. C.; LOVISON, V. M. H.; PIEROZAN, N. J. Tecnologia de Transformação dos Elastômeros, Centro Tecnológico de Polímeros SENAI-CETEPO, São Leopoldo, 2000.

58. LINDE, D.R.; "CRC Handbook of Chemistry and Physics"; CRC Press; Boca Raton, Section 9; p. 65 a 75, 2004-2005

59. ZHANG, Y. Effect of Crosslink Structures on Dynamic Mechanical Properties Of Natural Rubber Vulcanizates under Different Aging Conditions. Journal of Applied Polymer Science, v. 81, p. 710 -718, 2001.

60. GUERRA, B. G.; FURTADO, C. R. G.; COUTINHO, F. M. B.. Avaliação Reológica de Elastômeros e suas Composições. Polímeros, São Carlos, v. 14, n. 4,2004.Disponível em: http://www.scielo.br/scielo.php?script=sci_arttext\& pid=S0104$14282004000400017 \&$ Ing=en\&nrm=iso >. Acesso em: 21.Fev.2013. 
61. GEHMAN, S. D.; MAXEY, F. S.; OGILBY, S. R. Vulcameter Determination of Best Cure, Rubber Chemistry and Technology, vol. 38, n. 4, p. 757$768,1965$.

62. ISAYEV, A. I.; DENG, J. S. Nonisothermal Vulcanization of Rubber Compounds, Rubber Chemistry and Technology, vol. 61, n. 2, p.340$361,1988$.

63. MORTON, M. Rubber Technology, Florida: Robert E. Krieger Publishing Company, 1981.

64. AKIBA, M.; HASHIM, A. S. Vulcanization and Crosslinking in Elastomer. Progress in Polymer Science, v. 22, p. 475, 1997.

65. RIMONDI, G.; TOTH, J. W.; KOUVANIS, J. Predictive Model for Reversiontype Cures. Tire Science \& Technology, TSTCA, v. 24. n.1, 1996.

66. FUSCO, J. V.; HOUS, P. Butyl and Halobutyl Rubbers. The Vanderbilt Rubber Handbook, R.T. Vanderbilt Company, Inc.: 13 ed., p.2, 1990.

67. DUBEY, V.; PANDEY S.K.; RAO, N. B. S. N. Research Trends In: The Degradation of Butyl Rubber. Journal of Analytical and Applied Pyrolysis. v. 34, p. 111-125, 1995.

68. TEINOV, A. V.; ZAVYALOV, N. V.; KHOKHLOV, Y. A.; SITNIKOV, N. P.; SMETANIN, M. L.; TARANTASOV, V. P.; SHADRIN, D. N.; SHORIKOV, I. V.; LIAKUMOVICH, A. L.; MIRYASOVA, F. K. Radiation Degradation of Spent Butyl Rubbers, Radiation Physics and Chemistry, v. 63, p. 245-248, 2002.

69. KARAAGAÇ, B.; SEN, M.; DENIZ, V.; GÜVEN, O. Recycling of Gamma Irradiated Inner Tubes in Butyl Based Rubber Compounds. Nuclear Instruments and Methods in Physics Research. B.65, p. 290-293, 2007.

70. MORTON, M. Rubber Technology, Nova York: Van Nostrand Reinhold, 2 ed, 1989.

71. NAGDI. K. Rubber as an Engineering Material: Guidelines for Users. Munique; Vienna; Nova York; Barcelona: Hanser Publishers, 1 ed, 1993.

72. EXXON MOBIL CHEMICAL. Exxon ${ }^{\text {tm }}$ Bromobutyl Rubber Compounding and Applications Manual.p.4-82, Disponível em:

$<$ http://www.exxonmobilchemical.com/Chem-

English/Files/Resources/Registered/ exxon-bromobutyl-rubbercompounding-and- applications-manual-en.pdf>. Acesso em: 8 Nov 2012. 
73. EXXON MOBIL CHEMICAL. Model Vulcanization Systems For Butyl Rubber, Halobutyl Rubber, And Bimsm Elastomers. p.4-82, Disponível em: <http://www.exxonmobilchemical.com/ChemEnglish/Files/Resources/Registered/ exxon-bromobutyl-rubbercompounding-and- applications-manual-en.pdf>. Acesso em: 8 Nov 2012.

74. ZAPP, R. L. Chlorobutyl Covulcanization Chemistry and Interfacial Elastomer Bonding. Rubber Chemistry and Technology, v. 46, n. 1, p. 251-274, 1973.

75. COOPER, W. J.; CURRY, R. D.; O'Shea K. Model Vulcanization Systems for Butyl Rubber, Halobutyl Rubber, And BIMSM Elastomers, Exxon Mobil Chemical, 2006.

76. KRESGE, E. N.; SCHATZ, R. H.; WANG, H. C. Isobutylene Polymers. Encyclopedia of Polymer Science and Engineering, v. 8, 2 ed, p. 423448, Nova York: John Wiley \& Sons Inc., 1987.

77. BARLOW, F. W. Rubber Compounding - Principles, Methods and Technics, Nova York: Marcel Dekker Inc., 2 ed, 1993.

78. GARBIN, V. J. Butílicas. Disponível em:<www.cenne.com.br/borrachabutílica.pdf>. Acesso em: 08 jun. 2013.

79. DEAN; J. A. Lange's Handbook of Chemistry. Nova York: MacGraw-Hill., $14 \mathrm{ed}, 1992$.

80. WADDELL, W. H.; TSOU, A. T. Butyl Rubber. In: Rubber Compounding, Chemistry and Applications. Nova York: Marcel Dekker, Inc., 1996.

81. EXXON MOBIL CHEMICAL Exxon ${ }^{T M}$ Butyl Rubber Curing Bladder Resin Vulcanization Systems. p. 1-44. Disponível em: <http://www.exxon mobilchemical.com/Chem-English/Files/Resources/Registered/exxon-butylrubber-curing-bladder-resin-vulcanization-systems-manual-en.pdf>. Acesso em: 8 Nov. 2012.

82. SMITH, WC. The Vulcanization of Butyl, Chlorobutyl Rubber, and Bromobutyl Rubber. In "Vulcanization of Elastomers". Ed G Alliger \& IJ Sjothun.Reinhold Publishing Corp, NY. 1964

83. SIRQUEIRA, A.S.; SOARES, B. G., O Efeito de EPDM Modificado com Grupos Mercapto ouTioacetato na Cinética de Vulcanização de Misturas NR/EPDM, Polímeros: Ciência e Tecnologia, Vol. 16,p. 299-304, 2006. 
84. FERRANDINO, M. P.; SANDRES, J. A.; HONG, S. W. Tetrabenzyl Thiuram disulfide: A Secondary Accelerator for Stable Cross Link Systems in Tyre Applications, In: Meeting of the American Chemical Society Rubber Division, Filadelfia, USA, 1996.

85. LAGARINHOS, C. A. F.; TENÓRIO, J. A. S. - Reutilização, reciclagem e valorização energética de pneus no Brasil. Polímeros: Ciência e Tecnologia, v. 18, n. 2, p. 106-118, 2008.

86. LLOYD, C. A. Evaluation of Waste Tire Devulcanization Technologies. California Environmental Protection Agency, C. 2, p.4, 2004. Disponível em: <http://www.ciwmb.ca.gov/Publication/Tires/62204008.pdf>. Acesso em: 18 Fev. 2006.

87. SCURACCHIO, C. H.; BRETAS, R. E. S.; ISAYEV, A. I. - Blends of PS with SBR Devulcanized By Ultrasound: Rheology and Morphology, Journal of Elastomers and Plastics, v. 36, p. 45-75, 2004.

88. LEVIN, V. Y.; KIM, S. H.; ISAYEV, A.I.; VON MEERWALL, E.; MASSEY, J. "Ultrasound Devulcanization of Sulphur Vulcanized SBR: Crosslink Density and Molecular Mobility"; Rubber Chemistry and Technology, v. 69, p. 103-104, 1996.

89. ROY, C.; LABRECQUE, B.; CAUMIA, A., Recycling of Scrap Tires to Oil and Carbon Black by Vacuum Pyrolysis. Resources, Conservation and Recycling, v. 4, n. 3, p. 185-255, 1990.

90. BINGLIN, W.; ZIYAN, X.; XINGMIAO, Z.; SHIMING, M.; YUXI, Z.; DAOMING, S. Study And Application of The Radiation Reclaiming Waste Butyl Rubber Products By Gamma Rays. Radiation Physics and Chemistry. v. 42, p. 215-218, 1993.

91. ISAYEV, A. I.; CHEN, J.; TUKACHINSKY, A. Novel Ultrasonic Technology for Devulcanization of Waste Rubbers. Rubber Chemistry and Technology, v. 68, n. 2, p. 267-280, 1995.

92. MANUEL, H. J.; DIERKES, W.; HENDRIKS, A. Butyl Reclaim in Inner Liner Aplications. KGK. Kautschuk, Gummi, Kunststoff. v. 53, n. 12, p, 730-734, 2000.

93. WESTINGHOUSE SAVANNAH RIVER COMPANY, LLC Wicks, G. G.; Schulz, R. L; Clark, D. E.; Folz, D. C. Microwave Treatment of Vulcanized Rubber. US Patent 6420457, 4.Abr.2000, 16.Jul.2002.

94. TANG, Y. Recycled Rubber Processing and Performance Enhancement. US Patent 6590042, 3.Out.2001, 7.Ago. 2003. 
95. WENLAY, F.; ISAYEV, A. I.; MEERWALL, E. Molecular Mobility in Ultrasonically Treated Butyl Gum and Devulcanized Butyl Rubber. Polymer Engineering and Science. v.45, n. 25, p. 8459-8467, 2004.

96. JANA, C. K.; DAS, C. K. Recycling Natural Rubber Vulcanizates Through Mechanochemical Devulcanization, Macromolecular, v. 13, n.1, p. 30-38, 2005.

97. WENLAY, F.; ISAYEV, A.I, Recycling of Tire-Curing Bladder by Ultrasonic Devulcanization. Polymer Engineering and Science. v. 46, n. 1, p. 8-18, 2006.

98. ZEID, M. M. A.; RABIE, S. T.; NADA, A. A.; KHALIL, A. M.; HILAL, R. H. Effect of Gamma Irradiation on Ethylene Propylene Diene Terpolymer Rubber Composites. Nuclear Instruments and Methods in Physics Research Section B: Beam Interactions with Materials and Atoms, v. 266, n.1, p. 111-116, 2008.

99. VAN DUIN, M.; NOORDERMEER, J. W. M.; VERBRUGGEN, M. A. L.; VAN DER, D. L. Method for Devulcanizing Rubber With an Amine. US Patent EP 200963131, 27.Jan.2009.

100. LIANG, Z.; QIUYING L.; CHIFEI W. Properties Of Waste Butyl Rubber Reclaimed And Recured By Haake Rheometer, Journal China Rubber Industry, v.06, p. 135-142, 2010.

101. ROMUALDO, A. C. A.; SANTOS, D. E.; CASTRO, L. M.; MENEZES, W. P.;PASQUALETTO, A.; SANTOS, O. R. Pneus Inservíveis como Agregados na Composição de Concreto para Calçadas de Borracha. 3rd International Workshop Advances in Cleaner Production - Cleaner Production Initiatives and Challenges for a Sustainable World - São Paulo, São Paulo, 2011.

102. WEBER, T.; ZANCHET, A.; CRESPO, J. S.; OLIVEIRA, M. G.; SUAREZ, J. C. M.; NUNES, R. C. R. Caracterização de Artefatos Elastoméricos Obtidos por Revulcanização de Resíduo Industrial de SBR (Copolímero de Butadieno e Estireno), Polímeros, São Carlos, v. 21 n. 5, p. 429-435, 2011.

103. HIRAYAMA, D.; SARON C. Moagem e Devulcanização por Micro-Ondas da Borracha Estireno-Butadieno (SBR). Revista Eletrônica de Materiais e Processos, v. 7, n. 1, p. 34-38, 2012.

104. TAO, G.; HE, Q.; XIA, Y.; JIA, G.; YANG, H.; MA, W. The Effect of Devulcanization Level on Mechanical Properties of Reclaimed Rubber by Thermal-Mechanical Shearing Devulcanization. Journal of Applied Polymer Science, 30.Jan.2013 (Article first published online). 
105. MILLER, A. A., Effects of High-Energy Radiation on Polymers, Annals of the New York Academy of Sciences, Radiation and High-Temperature Behavior of Textiles, v. 82 , n.3, p. 647-795, 1959.

106. CHMIELEWSKI, A.; HAJI-SAEID, M., Radiation processing technologies: Past, present and future. Radiation Physics and Chemistry, v. 71, p. 1721, 2004.

107. MAKUUCHI, K.; CHENG, S. Radiation Processing of Polymer Materials and Its Industrial Applications, Nova York: John Wiley \& Sons Inc, p.1, 2012.

108. CHAPIRO, A., Radiation induced polymerization. Radiation Physics Chemistry, v. 14,p. 101-106, 1979.

109. O'DONNELL, J. H.; SANGSTER, D. F., Principles of Radiation Chemistry, London: E. Arnold, 1970.

110. BRADLEY, R. Radiation Technology Handbook, Nova York: Marcel Dekker, Inc., 1984.

111. CHARLESBY, A. Effect Of High Energy Radiation on Long Chain Polymers, Nature, v. 171, n.167, 1953.

112. LAWTON,E. J.; BALWIT, J. S. Irradiation of Polymers By High Energy Electrons. Nature, v. 172, n. 76. 1954.

113. CHAPIRO, A., Radiation Chemistry of Polymeric Systems, Nova York: Interscience Publishier, 1962.

114. TABATA, Y.; ITO, Y.; TAGAWA, S. CRC Handbook of Radiation Chemistry. Boca Raton, Flórida: CRC Pess, 1990.

115. DAWES, K.; GLOVER, L. Effects of electron beam and $\gamma$-irradiation on polymer materials. In: Physical Properties of Polymers Handbook, American Institute Of Physics, Woobury: AIP Press, c. 41, 1996.

116. CHANDRA, R.; SUBHAS, H. V.; VERM, A. K. Changes in Physical Properties and Molecular Structure of Butyl Rubber During Radiation. Polymer, v. 23, p.1457-1460, 1982.

117. ZAHARESCU, T.; POSTOLACHE, C.; GIURGINCA, M. The Structural Changes in Butyl and Halogenated Butyl Elastomers During Gamma Irradiation, Journal of Applied Polymer Science, v. 59, n. 6, p. 969-974, 1996. 
118. INTERNATIONAL ATOMIC ENERGY AGENCY (IAEA). Gamma Irradiator for Radiation Processing (IAEA Brochure). Viena, 2000.

119. INTERNATIONAL ATOMIC ENERGY AGENCY (IAEA). Directory of Gamma Processing Facilities in Member Stats . IAEA- DGPF/CD, Viena, 2004.

120. WOODS, R.; PIKAEV, A. Applied radiation chemistry, Radiation processing, Nova York: John Wiley \& Sons Inc, 1994.

121. SCAGLIUSI, S. R.; CARDOSO, E. C. L.; PARRA, D. F.; LIMA; L. F. C. P; LUGÃ,O A. B. Evaluation of "Payne Effect" in Radiation-Induced Modification of Chlorobutyl Rubber, Radiation Physics and Chemistry, v. 84, p.42-46, 2013.

122. ZAHARESCU, T.; CAZAC, C.; JIPA, S; SETNESCU, R. Assessment on Radiochemical Recycling of Butyl Rubber, Nuclear Instruments and Methods in Physics Research, Section B: Beam Interactions with Materials and Atoms, v. 185, p. 360-364, 2001.

123. BÖHM G. G. A ; TVEEKREM J. O.,The Radiation Chemistry of Elastomers and Its Industrial Applications. Rubber Chemistry and Technology,v. 55, n.3, p.575-668,1982.

124. NENITESCU, C. D., Organic Chemistry, 4a Edition, Technical Bucharest, Romenia, p.102, 1956.

125. HILL, D.J.T.; O'DONNEL, J.H.; PERERA, M.C.S., POMERY, P. J. High Energy Radiation Effects on Halogenated Butyl Rubber. In: Polymer. v.36, n. 22, p. 4185-4192, 1995.

126. DENVER J. A. Low Earth OrbitalnAtomic and Ultraviolet Radiation Effects on Polymers, Nasa Technical Memorandum 103711, 1991.

127. BARTTACHARYA, A. Radiation and Industrial Polymer. Progress in Polymer Science. v. 35, n.3, p. 371-401, 2000.

128. HILL, D. J. T.; O'DONNEL, J. H.; PERERA, M. C. S.; POMERY, J. P., Determination of Scission and Crosslinking in Gamma Irradiated Butyl Rubber, Radiation Physics and Chemistry, v. 40, p. 127-138 1992

129. RANBY, R; RABECK, J. F., ESR Spectroscopy in Polymer Research, Berlim: Springier Verlag, v. 5, 1977.

130. YANG, J. Radiation Recycling of Butyl Wastes. In: COOPER, J. W.; CURRY, R. D.; O'SHEA, E. K., Environmental Apllications of lonizing Radiation. Nova York: Wiley, p.601-611, 1998. 
131. YANG, J., LIU W. In: Technological Development of Irradiated Reclamation of Butyl Rubber Wastes, France: IAEA Consultants Meeting, p.19-21, 2000.

132. DROZDOVSKI V. F. J.; KAPLUNOV, M. Y.; MIHAILOVA, V. V. Reclaim from Resin Cured Butyl Rubber by Radiation Method. Rezina: Kauch, v. 9, p. 26, 1974.

133. KALINICHENKO, V. N.; BLOH, G. A.; VAKSER, A. Y.; SULYAEVA, N. P. Application of Radiated Butyl Reclaim in Tire Stock. Shin Resinotehnicheskih: Proizvod, v. 10, p. 12, 1983.

134. DAVISDSON, W L.; GEIB, J. G. The Effects of Pile Bombardment on Uncured Elastomers, Journal of Applied Physics, v. 19 n.5, p.427-433, 1948.

135. WANG, B.; XU, Z.; ZENG, X.; MA, S.; ZHANG, Y.; SUN, D. Study And Application on The Radiation Reclaimed Waste Butyl Rubber Products by $Y$ Rays. Radiation Physics and Chemistry, v. 42, p. 215-218, 1993.

136. TELNOV, A. V.; ZAVYALOV, N. V.; KHOKHLOV, Y. A.; SITNIKOV, N. P.; SMETANIN, M. L.; TARANTASOV, V. P.; SHADRIN, D. N.; SHORIKOV, I. V.; LIAKUMOVICH, A. L.; MIRYASOVA, F. K. Radiation Degradation of Spent Butyl Rubbers. Radiation Physics and Chemistry, v. 63, p. 245-248, 2002.

137. ZHAO, W.; PAN, X. EDS Technology of Radiation Processing and its Applications. Beijing, China: Weapon Industry, 2003.

138. SEN, M.; UZUN, C.; KANTOGLU , Ö.; ERDOGAN, S. M.; DENIZ, V.; GÜVEN, O. Effect of Gamma Irradiation Conditions on The RadiationInduced Degradation of Isobutylene-Isoprene Rubber, Nuclear Instruments and Methods in Physics Research, Section B: Beam Interactions with Materials and Atoms, v. 208,p. 480-484, Ago, 2003.

139. VAGIZOVA, R. R.; KHAKIMULLIN, YU. N.; KHARLOV; V. A.; STEPANOV, P. A.; PALYUTIN, F. M. Waterproofing Mastics Based on RadiationReclaimed Butyl Rubber.Polymer Science, Series C, v.49, p.176-178, 2007.

140. LANDINI, L; ARAÚJO, S. G.; LUGÃO A. B.; WIEBECK, H. Preliminary Analysis to BIIR Recovery Using the Microwave Process, European Polymer Journal, v. 43, i. 6, Pages 2725-2731, Jun, 2007.

141. KHAKIMULLIN, N.; VAGIZOVA, R. R.; STEPANOC, P. A. The Possibility of Using Radiation-Reclaimed Butyl Rubber In The Building Industry, Polymer Science, Series C, v. 2, n.4, p. 138-139, 2008. 
142. SMITH, M.; BERLIOZ, S.; CHAILAN, J. F. Radiochemical Ageing of Butyl Rubbers For Space Applications, Polymer Degradation and Stability, v. 98, i. 2, Pages 682-690, Fev, 2013.

143. ANNUAL BOOK OF ASTM STANDARDS. Standard Practice for RubberMaterials, Equipment, and Procedures for Mixing Standart Compounds and Preparing Standard Vulcanized Sheets. v. 09.01, 2008 (ASTM D3182).

144. MARTINS, M. D., Reciclagem Termoquímica de Resíduos de Plásticos e de Pneus Por Pirólise. 2009. Dissertação (Mestrado) - Universidade de Aveiro, Portugal.

145. FERNLEY, H.; DONALD, A.; CARL, F., Method of Reclaiming Scrap Vulcanized Rubber; US Patent 2461192, 02.Nov.1949.

146. ANNUAL BOOK OF ASTM STANDARDS. Standard Test Method for Rubber Property - Durometer Hardness, v. 09.01, 2008 (ASTM D-2240).

147. ANNUAL BOOK OF ASTM STANDARDS. Standard Test Methods for Vulcanized Rubber and Thermoplastic Rubber and Thermoplastic Elastomers - Tension, v. 09.01, 2008 (ASTM D-412).

148. ANNUAL BOOK OF ASTM STANDARDS. Standard Test Method for Rubber, Raw - Determination of Gel, Swelling Index, and Dilute Solution Viscosity, v.09.01, 2008 (ASTM D-3616).

149. GHANI, S.A.; MADKOUR, T.M.; OSMAN, H.M.; MOHAMED, A.R. Study of the Electrical Properties and Swelling Mechanism in Compressed Butyl Rubber Loaded with Carbon Black, Journal of Applied Polymer Science, v.81, n. 13, p. $3169-3177,2001$.

150. ANNUAL BOOK OF ASTM STANDARDS. Standard Test Method for Rubber Property - Vulcanization Using Oscillating Disk Cure, v. 09.01, 2008 (ASTM D-2084).

151. ANNUAL BOOK OF ASTM STANDARDS. Standard Test Methods for Rubber-Viscosity, Stress Relaxation, and Pre-Vulcanization Characteristics (Mooney Viscometer), v.09.01, 2008 (ASTM D1646 - 07)

152. MOUSA, A.; ISHIAKU, U. S.; MOHD ISHAK, Z. A., Rheological and viscoelastic behavior of dynamically vulcanized poly(vinyl chloride)epoxidized natural-rubber thermoplastic elastomers, Journal of Applied Polymer Science, v. 74, n. 12, p. 2886-2893, 1999. 
153. VISCONTE, L. L. Y.; MARTINS, A. F.; NUNES, R. C. R.; SUAREZ, J. C. M.,Misturas NR/SBR: modos de preparação e propriedades. Polímeros, v.11, n.2, p. 76-81, 2001.

154. NELSON, P. A.; KUTTY, S. K. N. Cure Characteristics and Mechanical Properties of Butadiene Rubber/Whole Tyre Reclaimed Rubber Blends. Progress in Rubber, Plastics \& Recycling Technology. v. 18, n.2, p. 8597, 2002 .

155. ADACHI, k.; NAKAMOTO, T. KOTAKA, T. Swelling Equilibrium of solution Crosslinked Polybutadieno Networks in Polysoprene Solutions, Macromolecules, v. 22, p. 3106 - 3111, 1989.

156. MILLER-CHOU, B. A.; KOENIG, J. L. A Review of Polymer Dissolution. Polymer Degradation and Stability. v.28, p.1223-1270, 2003.

157. CHARLES, E.; CARRAHER, J. Polymer Chemistry. 6a Edition, Revised and Expanded. New York: Marcel Dekker, Inc. 2003.

158. DUBROVIĆ, I.; KLEPAC, D.; VALIĆ, S.; ŽAUHAR, G. Study Of Natural Rubber Crosslinked in the State of Uniaxial Deformation, Radiation Physics and Chemistry, v. 77, n. 6, p. 811-817, 2008.

159. IGNATZ, F.; RODGERS, B.; - "Vulcanization", in: Rubber Compounding Chemistry and Applications, Rodgers, B., (Ed.), Marcel Dekker, New York, 2004.

160. SPENADEL, L.; R. J. GOOD. Synthetic Rubber for Self-sealing Fuel Tanks. Industrial and Engineering Chemistry, v.51, n.8, p.935-936. 1959.

161. GIBALA, D.; HAMED, G. R., Cure and mechanical behavior of rubber compounds containing ground vulcanizantes. Parte I - Cure Behavior, Rubber Chemestry Technology, v. 67, p. 636 - 648,1994.

162. ISMAIL, H.; NORDIN, R.; NOOR, A. M., Cure Characteristics, tensile Properties and Swelling Behavior of Recycled Rubber Powder- Filled Natural Rubber Compounds, Polymer Testing. v. 21, p. 565-569, 2001.

163. PESSOA, D.; BANDEIRA, M. A. M.; CAMPOS, R., Evaluation of Influence of Recycled Rubber Powder in the Natural Rubber Compound Properties of Enginnering Parts of the Automotive Sector. SAE International, p. 11, 2010.

164. MELLO, I. L.; SOARES, B. G.; COUTINHO, F. M. B.; NUNES, D. S. S. Influência Das Características Estruturais sobre a Processabilidade do Polibutadieno Alto Cis. Polímeros, v.14, n.4, p. 235-241, 2004. 